\title{
ठํ.
}
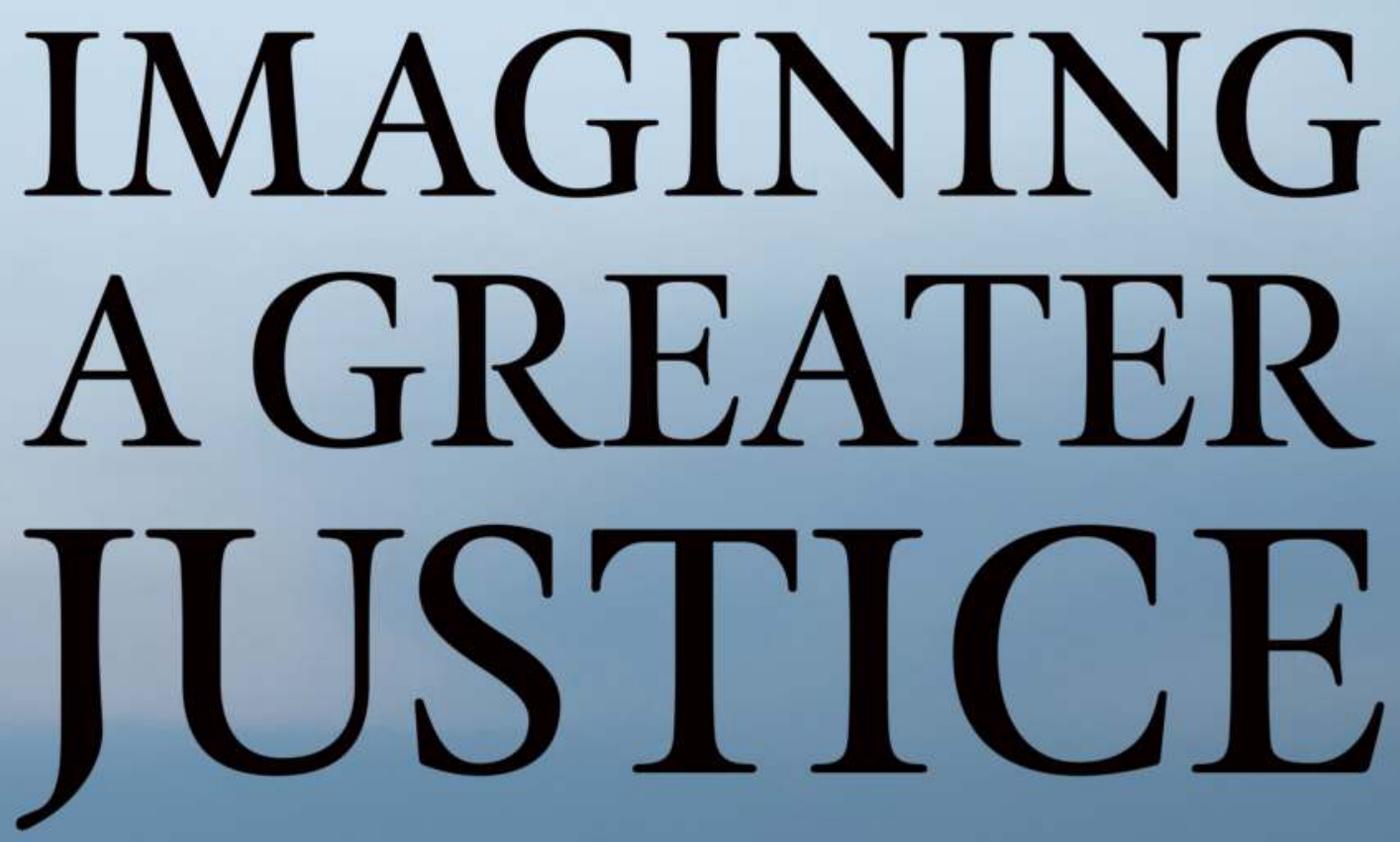

GRIMINAL VIOLENGE, PUNISHMENT AND RELAHONAL JUSTICE 


\section{IMAGINING A GREATER JUSTICE}

Even for violent crime, justice should mean more than punishment. By paying close attention to the relational harms suffered by victims, this book develops a concept of relational justice for survivors, offenders and community. Relational justice looks beyond traditional rules of legal responsibility to include the social and emotional dimensions of human experience, opening the way for a more compassionate, effective and just response to crime.

The book's chapters follow a journey from victim experiences of violence to community healing from violence. Early chapters examine the relational harms inflicted by the worst wrongs, the moral responsibility of wrongdoers and common mistakes made in judging wrongdoing. Particular attention is paid here to sexual violence. The book then moves to questions of just punishment: proper sentencing by judges, mandatory sentences approved by the public, and the realities of contemporary incarceration, focusing particularly on solitary confinement and sexual violence. In its remaining chapters, the book looks at changes brought by the victims' rights movement and victim needs that current law does not, and perhaps cannot meet. It then addresses possibilities for offender change and challenges for majority America in addressing race discrimination in criminal justice. The book concludes with a look at how individuals might live out the ideals of a greater-relational-justice.

Samuel H. Pillsbury is Professor of Law and Frederick J. Lower Fellow at Loyola Law School, Los Angeles. He teaches criminal law, criminal practice and American legal history. A nationally recognized scholar in criminal responsibility, punishment and emotion and the law, his previous books include Judging Evil: Rethinking the Laws of Murder and Manslaughter and How Criminal Law Works. After college, Pillsbury was a reporter covering police and courts in North Florida. He then earned his law degree at the University of Southern California, where he graduated first in his class. He clerked for US District Judge William Matthew Byrne, Jr., and served as an Assistant United States Attorney in Los Angeles before going into teaching. In 2006 he was ordained as an Episcopal deacon. He has volunteered as a chaplain in LA juvenile detention halls and jails, as well as prisons in California and New York. He has also worked with survivors of homicide and families with loved ones in prison. 
"This is a very important book and I am hopeful it finds a wide readership. Pillsbury has galvanized our imagination of the justice system we actually could have. He manages to get underneath all the issues we need to explore with sophistication, keen insight and great heart. He proposes a point of view both larger and more humble and our country will benefit greatly... if we listen to him."

Gregory Boyle, S.J. Founder of Homeboy Industries. Author of Tattoos on the Heart: The Power of Boundless Compassion.

"This is an important piece of scholarship that offers meaningful insights and novel ways of thinking about issues of law, justice and the human condition. It contains numerous "aha!" passages that inspire head nodding in recognition of the fundamental truths laid bare. The author's style successfully captures legal nuances without being tedious or overly technical. The issues explored could not be more timely; indeed, with recent broad societal recognition of issues of sexual abuse and harassment the prescience of the author's observations border on startling. The discussion of racism-particularly the pervasiveness of unconsciously held attitudes about race-could significantly affect individual attitudes and legal and social policies."

James Acker, Distinguished Teaching Professor, School of Criminal Justice, University at Albany

"This lucid and engaging book reconceptualizes criminal law in a fascinating way, drawing together a number of important strands of the discussion that are too often treated separately: criminal law, jurisprudence and philosophy, psychological questions, practical questions of institutional design and even spiritual questions. It also considers topics that are rarely treated in standard criminal law accounts: most particularly the role of the victim. One of the book's unusual strengths is that although grounded in legal jurisprudence, it is highly attuned to — and comfortable discussing - the emotional aspects of crime and punishment."

Susan A. Bandes, Centennial Professor of Law Emeritus, DePaul University College of Law

“I have long admired Samuel Pillsbury's writing on crime and punishment for its intellectual rigor and commitment to make the law more just and humane. In Imagining a Greater Justice: Criminal Violence, Punishment and Relational Justice he has produced his most important work. Drawing on law and social science and on his own work with crime victims and offenders, Pillsbury details the complex harms suffered by victims of violence and explores how offenders have come to commit violence. He 
creatively employs the perspectives of the different vocations he has followed-journalist, attorney, academic and Episcopal deacon-to develop a concept of relational justice for crimes of violence. Relational justice includes punishment, but sees justice as finally a community endeavor that should help victims heal and offenders be redeemed. Imagining A Greater Justice challenged some of my own views about crime and punishment; I am confident that it will challenge many others, as the best writing often does."

Jeffrie G. Murphy, Regents' Professor of Law, Philosophy, and Religious Studies, Arizona State University

"The author is well-positioned to write this book, given his multiple professional commitments and expertise. He clearly brings both knowledge and compassion to the project. Addressing criminal justice through the lenses of punishment and healing for all is an important and innovative approach."

Monica J Casper, Professor of Gender and Women's Studies; Associate Dean for Faculty Affairs, College of Social and Behavioral Sciences, University of Arizona 


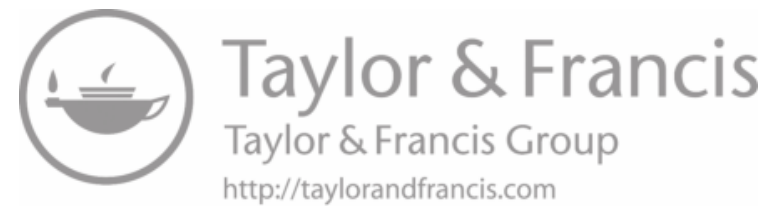




\section{IMAGINING A GREATER JUSTICE}

Criminal Violence, Punishment and Relational Justice

Samuel H. Pillsbury 
First published 2019

by Routledge

52 Vanderbilt Avenue, New York, NY 10017

and by Routledge

2 Park Square, Milton Park, Abingdon, Oxon OX14 4RN

Routledge is an imprint of the Taylor \& Francis Group, an informa business

(C) 2019 Samuel H. Pillsbury

The right of Samuel H. Pillsbury to be identified as author of this work has been asserted by him in accordance with sections 77 and 78 of the Copyright, Designs and Patents Act 1988.

With the exception of Chapter 10, no part of this book may be reprinted or reproduced or utilised in any form or by any electronic, mechanical, or other means, now known or hereafter invented, including photocopying and recording, or in any information storage or retrieval system, without permission in writing from the publishers.

Chapter 10 of this book is available for free in PDF format as Open Access from the individual product page at www.routledge.com. It has been made available under a Creative Commons Attribution-Non Commercial-No Derivatives 4.0 licence.

Trademark notice: Product or corporate names may be trademarks or registered trademarks, and are used only for identification and explanation without intent to infringe.

Library of Congress Cataloging-in-Publication Data

Names: Pillsbury, Samuel H., author.

Title: Imagining a greater justice : criminal violence, punishment, and relational healing / Samuel H. Pillsbury.

Description: 1 Edition. | New York : Routledge, 2019. | Includes index.

Identifiers: LCCN 2018035006 (print) | LCCN 2018053034 (ebook) |

ISBN 9780429424922 (Ebook) | ISBN 9781138354173 (hardback)

ISBN 9781138354197 (pbk.) | ISBN 9780429424922 (ebk)

Subjects: LCSH: Criminals--Rehabilitation. | Social justice. |

Criminal justice, Administration of. | Punishment. | Violence.

Classification: LCC HV9275 (ebook)

| LCC HV9275 .P54 2019 (print) | DDC 364.6--dc23

LC record available at https://lccn.loc.gov/2018035006

ISBN: 978-1-138-35417-3 (hbk)

ISBN: 978-1-138-35419-7 (pbk)

ISBN: 978-0-429-42492-2 (ebk)

Typeset in Bembo

by Taylor \& Francis Books 


\section{CONTENTS}

Acknowledgments

Introduction

PART ONE

$\begin{array}{ll}\text { Judging Wrong } & 13\end{array}$

Introduction to Part One 15

1 Violence and the Soul 16

2 Blame for Moral Disregard $\quad 42$

3 Misjudging Wrong $\quad 67$

PART TWO

$\begin{array}{ll}\text { Just Punishment } & 97\end{array}$

Introduction to Part Two 99

4 Punishing with Regard 100

5 Cruelty by Law: Mandatory Life in California 129

6 Our Prisons, Our Prisoners: Cruelty in Penal Practice 159 
viii Contents

\section{PART THREE}

Relational Justice

Introduction to Part Three

7 Victims and Justice under Law

8 Victims and Relational Justice 222

9 Redeeming the Responsible 243

10 Healing the American Community: Race and Criminal Justice 272

11 Living a Larger Justice 302

Index 


\section{ACKNOWLEDGMENTS}

I have incurred many debts of thanks over the years that I have spent on this book. The financial support of Loyola Law School, Los Angeles, in the form of research grants and a sabbatical in 2013-14, was critical to conceiving and completing the book. The hospitality provided by the School of Criminal Justice, State University of New York, Albany which gave me an office and research resources during my sabbatical year was also enormously helpful. My particular thanks to Jim Acker for arranging my Albany visit and to Michele Fox at CSJ for making it work on a daily basis.

My sincere thanks to those who read parts of this book at different times and different stages, including Susan Bandes, Andrew Carrell, Laurel Kaufer, Mike Kennedy S.J., Kieran Kennedy, Jeffrie Murphy, Tom Morowitz, Linda Pillsbury, Robert Shepard and Scott Taylor. My special thanks go to my Loyola Law colleague, Scott Wood, and to Rebecca Moos, my research assistant, for their supportive readings of the complete manuscript, on several occasions. These always gave me a needed boost.

I received valuable research assistance from Loyola Law School students Michele Balady, Nzhdeh Alfie Aghazaryan, Rebecca Moos and Grant Ellfeldt. Thelma Terre, my administrative assistant at Loyola Law School, has my unending gratitude for her help throughout my academic career.

I need to thank those who have been my trainers, guides and supporters in my work with the incarcerated. To Cheryl Bonacci and Javier Stauring, thanks for helping me get started in detention ministry, to Mike Kennedy for spiritual guidance and great good humor, the Rev. Michael Ojewale, and especially to Dennis Gibbs and Greta Ronningen, directors of PRISM Restorative Justice for their support of my ministry inside. I also need to thank the corrections staffs and 
officers in the Twin Towers Correctional Institution in Los Angeles, the Barry J. Nidorf Juvenile Hall, in Sylmar California and the Green Correctional Facility, in Coxsackie, New York for their assistance.

Rita Chairez, Ruett Foster, George Horan, Sue Reif and Suzanne Neuhaus taught me much about survivors of violence. Some of what they taught me appears here. My thanks to Elizabeth Calvin for including me in Healing Dialogues and Action, and providing an extraordinary example of leadership in criminal justice reform.

Finally, my thanks to the youth, men and women who have talked and worshipped, laughed and cried with me in juvenile detention halls, jails and state prisons, and who have taught me things about life and the criminal justice system that I would otherwise never have known. 


\section{INTRODUCTION}

This is a book about how we imagine justice. What we cannot imagine, we certainly cannot achieve.

As a society, our most pressing need for justice comes after criminal violence. A young man is shot in a crosswalk on a summer's night and bleeds to death on the asphalt. A wife is punched and choked by her husband. A girl is sexually molested by her basketball coach. Hearing about these events, our feelings move quickly from sympathy for victims to anger at perpetrators. We hope to see their swift arrest, conviction and punishment. Then we can say that justice has been done.

But we need more than law to do justice in these cases. We need a justice commensurate with the harm. This means we need a justice that comprehends the grief of the young man's family, the soul hurts of the beaten woman and the girl whose world has been utterly transformed by sexual violation. We need a justice that comprehends how violence shatters survivors' sense of trust and place in community. Can we imagine this? I think we can. But we should not stop here.

Can we imagine a justice that respects an offender's humanity? Can we imagine a justice that treats someone who has spent half of his life locked up for serious crime as a human being capable of change? Can we imagine an ideal of justice that says we should try to reconcile with him to make a lasting peace in our communities? Can we imagine a justice that acknowledges the racial violence of the past and the racial denials and misunderstandings that undercut the trust needed for effective law enforcement? Can we imagine a justice concerned with healing the community after violence? 
Imagining a justice this big will be a stretch for many. I know it has been for me.

I have spent most of my professional life working on justice defined by what happens in the courtroom. As a young man I swore allegiance to justice under law as an officer of the court - a federal prosecutor. And I believe in it as much today, in my early 60 s, as I did when I was in my 20 s.

As the years have passed, though, my view of justice has changed according to my experience of life. I have slowly, often reluctantly, but with increasing conviction come to believe that our conception of justice in the United States is too small. It is too focused on the conduct and character of a few identified wrongdoers. Its concern with individual blame and punishment leaves unaddressed the deep needs of those most hurt by crimes of violence. It flatly ignores, even righteously dismisses, the needs of the incarcerated and their families.

Against the grain of an American culture that celebrates individual freedom and independence, I have come to appreciate how closely tied we are to each other, by bonds chosen and unchosen. The experience of surviving violence makes the strength of these bonds awfully clear. Our conception of justice should respect the reality of how we live in dynamic, interdependent relationship. In addition to holding persons responsible for their chosen actions, we need to take collective responsibility for legal and social structures that determine who belongs in society, and who does not. Belonging, it turns out, is the foundation of just and peaceful community.

We need to imagine what I call relational justice, which includes the rules and processes of the criminal law, but which is bigger in both scope and heart.

\section{Beyond the Headlines}

Over and over again, sudden explosions of violence demand our attention. American place names become shorthand for mass murder. In the writing of this book there have been: Newtown, Connecticut (Sandyhook Elementary School), Boston (the Boston Marathon bombings), San Bernardino (Inland Regional Center shooting), Charlottesville (Emanuel AME Church prayer meeting attack), Orlando (Pulse nightclub), Dallas (targeting of police officers), Sutherland Springs, Texas (First Baptist Church), Las Vegas (Route 91 Harvest country music festival), Parkland, Florida (Marjory Stoneman Douglas High School). There have been others, and unfortunately, likely will be many more, enough to make this list seem dated to future readers.

In this same time period, scandals about sexual violence have garnered headlines repeatedly. New revelations about sexual assaults on college campuses, at elite 
private schools, in US women's gymnastics and sexual violence and harassment by prominent persons in the media and entertainment industries have brought new attention to sexual violence. Bill Cosby and Harvey Weinstein head the current list of famous and powerful men who have become infamous by virtue of multiple accusations of sexual assault.

Meanwhile the nation, or parts of it, has been periodically consumed with controversies about police use of force, particularly in the killing of unarmed African American boys and men. The best-known names of the dead include Michael Brown, Eric Garner, Freddie Gray, Philando Castile, Walter L. Scott, and Tamir Rice. Again, there are many more, and, unfortunately, more likely to come in the future.

Headline events of terrible violence shock us. We try to understand. We talk about tragedy, fault and accountability in their wake. But it is in the nature of headline events that their significance fades for most of us within weeks or months. It is also in the nature of headline events that they spark a vigorous discussion of causes and responses, which generally leads to an impassioned, but much too familiar exchange of views about guns and race and police and morals and public safety that in most cases changes little.

This book is about looking beyond the headlines to the far more common forms of violence that garner little public attention, but do great harm. It is about appreciating how violence harms souls. This reveals the need for a bigger justice. It also suggests new approaches to criminal justice reform.

With violent crime rates at relatively low levels in most American jurisdictions today (compared to the late 20th century), and with new perspectives on criminal justice receiving a respectful hearing in many localities and states, there is much to talk about for those interested in criminal justice reform. But where to begin?

The choice of a beginning matters, for it can determine the direction of what follows. Here are some possibilities. We might begin with the history of race and criminal justice in America. American criminal justice makes no sense without our racial history. Or we might begin with the origins and current realities of mass incarceration, which is the most distinctive and most controversial aspect of American criminal justice today. Or we might begin with controversies about police use of force against minority men. Or, our initial focus might be on the politics of crime and punishment in the United States, which largely determines what is and what might be in criminal justice. These are all excellent places to begin. I will touch on all of these issues in this book. But I begin in a different place, with the deep pain that violent crime causes, and the moral responsibility of perpetrators. 


\section{Beginning with Violence}

The most pressing task for any criminal justice system is how to respond to crimes of violence. These are the wrongs we most fear. These are the offenses against community that threaten both private and public life.

Everyone knows that America has a violence problem. It's almost a cliché about the nation. Gang shootings, mass shootings, controversial police shootings. A proliferation of guns. Sexual violence at college, in the military, at work. Widespread domestic violence. These just top the list of violence issues that regularly demand our attention.

Many acknowledge that America has a major criminal justice problem as well. We expend enormous resources on a highly punitive approach to crime that disproportionately incarcerates racial minorities and the poor, that incarcerates on an industrial scale unique in the developed world and generally prefers to blame individuals for criminal acts rather than address underlying conditions like addiction and mental illness that are intimately connected to criminal behavior.

Our problems with violence and with criminal justice are inextricably intertwined. We would not be so punitive a people if we were not also so violent. Public fear of criminal violence, and the anger catalyzed by that fear, drives the fiercely punitive impulse in contemporary American law. As scholars have increasingly realized, the punishment of violent crimes is a major cause of mass incarceration today. ${ }^{1}$

Concern with violent crime is also central to our problems with race. Racial fears exaggerate violence fears, leading to many forms of race discrimination. Long-term patterns of violence in some minority communities, patterns that extend across generations, connect to a long history of race discrimination. We need a justice that can comprehend this past, and that encompasses community healing.

\section{Beginning with Pain: Listening to the Hurt}

I begin with listening to those hurt by wrongful violence. The hurt have much to teach us about the harms and wrongs of criminal violence, and thus about justice for violent wrongs. Survivors of violent crime can even teach us about life and death. But only if we listen closely and patiently.

For highly educated people - such as the kind who write and read books like this on criminal justice-close and patient listening to victims is difficult. Listening to victims is hard because it is slow; and smart people like to move fast. Get to the point, please. Yes, you've already said that-three times actually. It is hard because listening to the hurt, hurts. Staying with another person's pain for more than a brief 
time conveys some of that pain to the listener. Such listening can be difficult because it privileges feeling over thought. For those who love to discuss ideas and tend to treat emotions as symptoms rather than essential features of the human condition, sustained attention to emotion can be uncomfortable. Okay, I get that you feel that way, but we really need to focus on what can be done. Finally, to avoid unnecessary controversy, most public discussions of criminal justice center on norms of public health and safety. Who could be against public safety and health? But in listening closely to the hurt we hear of moral and spiritual injury. We enter the realm of good and evil, right and wrong, and matters of the soul. These are not terms that many who lead criminal justice policy discussions are comfortable with.

I begin with listening to victims of wrongful violence, because they can tell us about the harms and wrongs of such offenses in a way that no one else can. But we have to be careful to listen to what they say and not what we want them, or expect them, to say. Too often, victim voices have been heard only when they speak in an angry register, in support of new punitive measures. Their anger must be heard, but victims have much more to express than anger.

When we listen to victims closely we learn about relational losses from violence and the need for relational healing. We learn about harms to the soul and a loss of belonging. Listening to the most direct victims of wrongful violence, we learn how violence permanently changes lives, which makes significant today violence that occurred long ago.

This learning allows us to see fully persons and communities who have been hurt by violence. The numbers of the hurt and the depth of their injury turn out to be much greater than we had imagined, showing that justice requires a much greater response than we had imagined.

\section{Beginning with Wrongdoer Responsibility}

Finally, I begin with the individual moral and legal responsibility of offenders. This is just where most Americans start in responding to wrongful violence. Of course criminals should be held personally accountable for their horrible actions. It all starts with holding them responsible. Still there is a risk to starting in the usual place: we may end up in the usual place as well. Nothing may change.

In a democracy, change requires public persuasion, and that means starting the discussion where the public is. It means starting with public fear, anger and hope. With a subject that inspires strong emotions, as criminal violence does, arguments for change must speak to listener emotions as well as reason. This means we must speak personally. Emotions are how we experience and express the personal.

Also, where we start is not where we will end. 


\section{Where We (Might) End Up}

On a Wednesday morning in the second week of June, 2011, I sat in a basement classroom of the Cathedral of the Blessed Sacrament, a Catholic church one block from the state capitol in Sacramento, California. A group of about 20 sat at rectangular tables arranged in a square under bright fluorescent lights. Although it was just 9:30 in the morning, most of us were already tired from having arisen at four or five a.m. to catch flights from around the state to meet. It was an unusual group, comprised primarily of persons who had a family member serving a life sentence for murder, or who had lost a family member (or members) to murder. ${ }^{2}$

The public discussion of criminal justice issues in America today often mirrors the adversarial contest that takes place in the criminal courtroom. It is prosecution vs. defense, victims vs. defendants. We find some who frame the contest as good people against bad; others insist it is between basic due process and a primitive urge for payback. Divisions of race and class often lie just beneath the surface of the debate. The assumption of many seems to be that this is a zero sum game; one side wins, the other loses. None of this was true in that Sacramento basement room.

It was the second time we had met as a group. At a daylong gathering in Los Angeles a month earlier, participants had shared their personal stories. We heard of the murder of a loved one: a son or brother or other family member. The pain of the event was always alive in the speaker's voice and body, even if it occurred years before. Each person spoke of what this violence did to him or her and their family. Interspersed were accounts by others of a family member whose son or brother or sister was convicted of murder and is serving a life sentence. We heard about what this meant for the speaker and family. No one claimed that the two kinds of losses were equivalent. Sudden, violent death at the hands of another is a different category of harm than any prison sentence, however long. But the similarity of the survivor experience in individual and family loss, stemming from violence, was palpable.

At the Sacramento meeting, homicide survivors recalled their journeys from the darkness, anger and isolation caused by the crime. One said, "I don't want to be that person ... I don't want to go back to that. I don't want anyone to go back to that." Survivors rejected the idea of an opposition between themselves and offender family members. Again and again they sought to reassure those with a loved one in prison that what happened was not their fault and they should not feel shame. That reassurance proved powerful.

M., a young woman whose brother was convicted of first-degree murder for a crime committed at the age of 17 , and who is serving a sentence of life in prison without chance of parole, expressed thanks for support shown to her and her mother by others in the group. She said that for years, the feelings of hurt and guilt 
and shame because of the murder committed by her brother had been enormous. She said that she never really expected to feel the compassion of others for the family's pain: "maybe I felt like my family never really deserved it." E., whose son committed murder said, "I was closed myself for many years, working to keep from thinking about the guiltiness of what my son did. Now I feel selfish [about that], because there was nothing [I did] to give back. I got a lot of inspiration [from the day of sharing and want] to give back to the community. I want to do more."

B., whose younger brother is in prison, said that having a family member who committed murder, "you always feel guilty." She later added that because of her connection with others in this group, she felt like she was going through a midlife change. "I've spent so long feeling disconnected from society. I don't feel like I've been a part of anyone else's world. I kept myself apart. [This has helped] me come out of my shell so I can be a more productive member of society. I no longer feel as if I was as horrible as I did before. Thanks for helping [me] move forward."

There was in the room a sense of excitement and mission, of the possibility of life in a community not defined by us versus them.

To be clear, this was a select group, not necessarily representative of either family member survivors or persons with a loved one in prison. Each person present had traveled far, in every sense, to reach the place where they could speak as they did and to reach out to others. Still the sense of transformation felt by participants gives us a clue to what otherwise might seem impossible, which is an approach to criminal justice that takes both the wrongs of criminal violence and healing from violence seriously. By sharing personal pain and holding another's pain, participants created new community.

What happened could certainly be called therapeutic, but that would not be a sufficient descriptor. The change that occurred in participants' sense of themselves and their place in the world suggests what a full answer to the harms and wrongs of criminal violence might look like. It hints at what a greater justice might involve.

\section{Introducing Relational Justice}

This book joins an ongoing discussion about criminal justice in the United States. I should therefore say something about where it fits into this discussion and what it adds. Particularly I need to say something about what I call relational justice.

Much of the contemporary discussion of American criminal justice concerns the rules, principles and practice of criminal law; this book is no exception. The 
conviction and punishment of violent offenders is an important part of what follows. As is also common in contemporary books about criminal justice, I present a critique of current criminal law and practice, but less standardly for a legal work, my critique often uses nonlegal materials. This is the result of grounding the discussion in the experience of victims of violence. Throughout, I am concerned with the limits of current law's understanding of justice.

The book also engages the social science of criminal justice. This includes the study of victims, criminal behavior, criminal justice institutions and the political science of punishment. But because I do not use the quantitative tools of contemporary criminal justice analysis, nor present the results of a qualitative study, it does not fit the usual forms of a social science publication.

The book also draws on work in restorative justice. Restorative justice sees crime as a harm to community relationships that requires a community response. Once individual responsibility for harm-doing is established, a restorative justice process seeks the reconciliation of harm doer and community. This means healing. Restorative justice theorist John Braithwaite has written: "With crime, restorative justice is the idea that because crime hurts, justice should heal." 3 Particularly in Part Three of this book, I consider the place of healing in a bigger conception of criminal justice.

In its attention to the way that crime attacks individual and community relationships and the way that justice should include efforts to repair those relationships, the book draws on restorative justice values. ${ }^{4}$ There is an important difference between my approach here and restorative justice as usually understood, however. Restorative justice advocates generally resist any punitive response to crime. Justice should mean reconciliation, not punishment, they say. But I see punishment as an important part of doing justice in cases of serious violence. Punishment should never be seen as sufficient for justice, but it is often necessary to defend essential community values.

The last major influence on this book, and the source of the word relational in relational justice, is recent work in psychology on relationality. Relational theorists, many of them working from a feminist perspective, have studied how identity is shaped relationally. Instead of assuming that human persons are fully independent, largely self-contained individuals, a relational approach insists on seeing persons as beings whose very identity depends on social context—on relationship. This means that resolving conflicts between persons must go beyond assessing individual blame or excuse for particular actions to considering the past, present and future of relationships, individual and communal. We need a view of justice that incorporates the relational aspects of violent wrongdoing and victim healing with justice under law. We need a view of relational justice. 


\section{Getting Personal about Justice}

I take justice personally. I think most Americans do. Our nation has always seen justice under law as a foundational value. How many other nations put a legal document - the constitution — at the center of public life? But our apparent agreement on justice principles should not deceive. We have always been conflicted about what justice means, because justice depends on personal values and experience, which vary enormously. In this book I consider what justice means to us today - to each of us. And what it should mean.

Our consideration of justice will engage law and public policy, but it will also explore morals, emotions, relationships and the human spirit. These other dimensions shape our personal views of justice. Much that we get right and also that we get wrong lies in these other, more personal, dimensions. Exploring them will produce revelations about ourselves, and new possibilities for general agreement. It's an interesting phenomenon: the more personal we go, the closer to universal principles we may come.

This is a challenging book. It is meant to be. I question many deep-rooted assumptions about right-doing and wrong-doing in America. I challenge ideas about freedom and individuality and the obligations we owe strangers. I challenge standard oppositions. I am committed to finding the possibilities of and rather than emphasizing the distinctions of or. I will talk about individual and social responsibility, punishment and healing, law and morals, reason and emotion. Using and as a normative conjunction takes us to uncomfortable and sometimes confusing places, because it complicates ideas and emotions. But life in community is complicated, and so is the struggle for justice.

The stakes in our modern justice struggle are high. Justice disputes shape our politics and culture; they can inspire violent protest. Contemporary political divisions stem in part from our inability to reach agreement about public rights and wrongs and responsibility. As passions run high, we often end up shouting at each other about basic rights and wrongs. It can get very personal. Passion itself should not be derided, however. The hard work of justice is unsustainable without it.

\section{Where I Come From}

Finally, speaking of the personal, I should say something about my own background here. Views about crime and punishment often rest on very personal foundations. Certainly my background shapes what I offer in this book and what I do not. 
In the fall of 1977 I started work as a very much fish-out-of-water police reporter in Jacksonville, Florida. (A New England prep school and Ivy League college education may be wonderful preparation for many occupations, but being a police beat reporter in the South, at least in the late 1970s - not so much.) My next reporting assignment was the courthouse beat. I covered state criminal trials in Jacksonville. To my surprise, observing the law in action inspired me to become a lawyer myself. I attended law school in southern California, served as a law clerk to a federal judge and then worked as a federal prosecutor in Los Angeles. Since 1986 I have been a law professor in Los Angeles, teaching and writing about criminal law primarily. In 2006 I was ordained a deacon in the Episcopal church, and in addition to law teaching, have served as a volunteer chaplain, doing ministry and running programs in juvenile hall, jail and prison. I have also worked in recent years with several California-based organizations devoted to helping victims of violence.

From each of the professions I have practiced-journalism, law and ministry-I take critical methods and themes for this book. From journalism I take the importance of stories and first-hand experience. From law I take the constructs of individual responsibility, particularly moral responsibility. From faith I take a commitment to human value and the relational connections between persons that shape both individuals and community.

Also important has been my own personal experience with criminal violence. People close to me have been victims. That is not unusual. Wrongful violence touches most Americans, though its effects often go unrecognized. Some of the experiences of people close to me I recount here; most I do not, because those stories are theirs to tell and not mine. Where I can speak from my personal experience, I do, because addressing the wrongs of violence requires bringing personal experience to awareness. We cannot redress what we cannot, or will not, acknowledge.

\section{Book Overview}

Part One of the book begins with close listening to victims, wrongdoers and judges of wrongdoing. In Chapter 1 we examine the soul harms of criminal violence. Chapter 2 sets out the basic moral and legal responsibility of wrongdoers. Chapter 3 analyzes some common mistakes we make in judging the wrongs of others in America.

Part Two considers justice in punishment. Chapter 4 looks at determining a proper sentence following conviction. Chapter 5 uses the story of how California enacted mandatory life terms for juveniles and repeat felony offenders to critique 
increases in penal punitiveness in America. Chapter 6 considers the realities of incarceration, focusing on solitary confinement and sexual violence inside prison.

In Part Three, the book shifts to relational justice and the redemption of the hurt: victims and offenders particularly. Chapter 7 discusses what victims of violent wrongs seek from the legal system, both in basic law enforcement and victim rights. Chapter 8 details victim needs for relational healing and how relational justice values might inform legal processes. Chapter 9 looks at the redemption of violent offenders. Chapter 10 takes up problems with race in criminal justice, focusing on what majority (white) America too often misses about past and current realities.

The book concludes in Chapter 11 with how individuals might live out the ideals of a greater justice.

\section{Notes}

1 See John F. Pfaff, Locked In: The True Causes of Mass Incarceration and How to Achieve Real Reform (New York: Basic Books, 2017); Marie Gottschalk, Caught: The Prison State and the Lockdown of American Politics (Princeton, NJ: Princeton University Press, 2015).

2 The immediate reason for the gathering was to speak to legislators in support of SB 9, proposed legislation that was eventually enacted into law. The statute gave California courts authority to reconsider sentences of life without chance of parole given to juvenile offenders. The court could resentence the offender to make him eligible for parole consideration by the state's parole board. Each would have to serve a minimum of 25 years in prison before any possible release. Although the group was comprised of family members who had suffered a murder or murders in their family, and others who had a family member incarcerated for murder, all involved separate cases. Unlike some victim-offender mediations, this encounter did not involve perpetrator and victim in the same case.

3 John Braithwaite, Restorative Justice and De-Professionalization, 13 The Good Society 28, 28 (2004).

4 There is a large international literature on restorative justice. For an introduction see Howard Zehr, The Little Book of Restorative Justice (Brattleboro, VT: Good Books, 2015); John Braithwaite, Restorative Justice and Responsive Regulation (New York: Oxford University Press, 2002). 


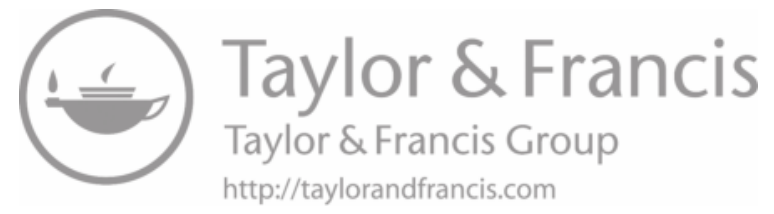


PART ONE

Judging Wrong 


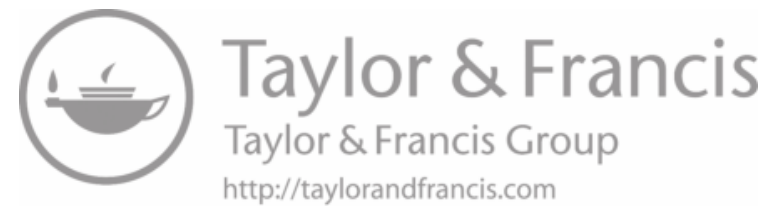




\section{INTRODUCTION TO PART ONE}

In the next three chapters, the familiar becomes unfamiliar. We will consider the harms of violent crime, the culpability of offenders, and how to judge wrongdoing. All familiar stuff. But in the process I will introduce new words and concepts to the discussion: souls and individual identity, blame and moral regard, melodrama and tragedy.

In Chapter 1, we will see that in addition to its physical and emotional harms, violence damages the souls of victims. This leads to an examination of individual identity. We see that our (very American) celebration of individual freedom and autonomy causes us to discount the power of relationships, including unchosen relationships, in shaping who we are.

In Chapter 2, I develop the principle of blame for moral disregard. Instead of linking blame to an intent to harm, we see that blame for criminal violence involves harm-doing where the actor fails to see the uniqueness of the other person and care for his or her good.

In Chapter 3, I explore how popular assumptions about good guys versus bad guys can distort our judgment about wrongdoing. Using examples from child sexual abuse scandals and race bias in criminal justice, we learn about the importance of moral regard in assessing wrongdoing. We learn about the hazards of relying on melodrama as our basic story form in criminal justice, and the potential of tragedy. 


\section{VIOLENCE AND THE SOUL}

There are no words. ${ }^{1}$

It's not the carnage that's horrible, though. It's the grief and sadness of it that is that will make your hair stand on end ....

When I was a reporter in North Florida I covered proceedings in a capital case in which a teen was charged with killing a young woman as she opened a café for business in the morning. Apparently she was killed as part of a robbery. She was stabbed to death.

The defendant, a white kid who looked like he belonged in high school, was silent throughout but he made a loud impression. He had an almost gleeful, smirking manner, as if he were picking his nose in front of the teacher, trying to impress the kids in the back of the class. He had been arrested near the cafe with the murder weapon (the knife) not long after the killing occurred. He told the police that he had been given the knife just minutes before by a man named "Mike," otherwise unknown to him. A ludicrous story.

I don't remember the case because of the defendant, though. It was the victim's surviving husband that engraved this case on my memory. He was a middle-aged man, considerably older than his wife. The husband was devastated, ravaged from the inside. He came to court early every morning, sat in front and stared hate at the defendant. He was in hell and seemed to wish nothing more than to take his wife's killer there with him.

I was startled by the man's presence. I couldn't have been surprised that having a loved one murdered was a devastating experience. I was surprised that his rage and 
heartbreak was so palpable. It seemed to vibrate in the room. In years since I have encountered victims in a similar state of anguish and rage on a number of occasions. The grief and anger is always tangible and always disturbing. It is agony.

This was one of my first encounters with the spirit devastation of violence. Everyone knows about it, sort of, but to really understand it we have to sit in its darkness, must remain in its presence until we feel the pain, or a little of it. Usually we find reasons to distance ourselves from the most hurt, perhaps after expressing our sympathies.

Sympathizing with the hurt will not be enough to understand their experience, however. As with my encounter with this distraught husband in a Florida courtroom, there remains a mystery about the nature of the connection between perpetrators and survivors. To understand its power and intimacy we need to explore how human beings make spirit connections. Then we may grasp how wrongful violence attacks the soul.

This is the chapter that some readers may be tempted to skip or skim, because the discussion will often seem distant from contemporary criminal justice issues. After hearing from victims in their own voices, we will talk about the soul, about confrontations with death, and the difference between understanding individual identity as autonomous or relational. Huh? But this is all central to the task at hand, which is building a strong conception of moral responsibility for criminal justice.

Grasping what I call the soul harms of violence is critical to understanding why the injury of wrongful violence goes so deep in the person, lasts so long, and affects so many others. It shows why we should impose major consequences on offenders even for acts that leave no lasting physical injury, as with many cases of sexual violence. Finally, appreciating the soul harms of violence helps us see the significance of personal and collective histories of violence. In later chapters we will see the particular importance of appreciating past racial violence.

Considerations of the soul lead to considerations of individual identity and criminal responsibility. The extent to which we are independent or interdependent persons shapes whether we see criminal responsibility as a purely individual matter, concerned only with the wrongdoer's legal acts or whether it will encompass social relationships that shape individual actions and social responses.

A construction analogy provides another way to explain the work of this chapter. In the process of building a home, digging and laying a foundation can be hard, expensive work. It can be tempting to rush through it, or do it on the cheap, saving time and money for all that follows: the framing, roofing, plumbing, electricity and finish work that produces the actual living space. But a well-made house sits on a strong foundation. There is no substitute. In this chapter we do the 
foundational work for constructing a revised conception of criminal justice in the rest of the book.

\section{Criminal Violence in America: A Land Familiar and Strange}

Americans have long had a special relationship with wrongful violence. ${ }^{3}$ Among economically advanced democratic nations, the United States has a high rate of violent crime, particularly for homicide. We have uniquely high levels of gun ownership, with minimal firearms regulation compared to other democracies. ${ }^{4}$ High rates of gun use in criminal violence follow, despite increased punishments in most jurisdictions for the criminal use of guns. Meanwhile, the United States is home to an entertainment industry that produces a vast array of entertainments for all manner of screens (movies, televisions, computers, phones) that depend on the depiction of criminal violence for dramatic energy.

We hear about wrongful violence all the time. Every day we encounter the world of violence in headlines and graphic images. This is a place of dramatic conflict, where sudden, frightening actions have terrible consequences, inspiring outrage and sadness. This is the land we know from the nightly news, the daily newspaper, from the endless iterations of crime shows on television, from movie thrillers to true crime books. In this land, all eyes focus on the pursuit of justice. The perpetration of crime must be followed by the perpetrator's capture and punishment (or death-the favored dénouement of the American crime show). Then, and only then, can the world be made right again.

We also know something about criminal violence by the numbers. Every year the FBI publishes national figures on crimes compiled by law enforcement agencies across the nation. Most states and cities tally crime numbers from year to year. Researchers compile statistics on crime rates per 100,000 persons, and victimization rates.

What we don't know so well, as a people, is the land we now enter, which is the land of spirit-pain that violence creates. This is a dark place, in which critical features are often hidden from public view and sometimes from private understanding as well. Details are not readily shared by its residents. Hurt and fear and guilt, grief, shame and sheer vulnerability, make residents wary of sharing their experience with strangers.

Yet we should never doubt the reality of this place. It is part of our world. The outward manifestations of spirit pain can be seen in PTSD and substance abuse, in anger issues and depression, self-mutilation and suicide, in family violence and social dysfunction. They should leave no doubt about the harm of violence to the inner person, which will in turn harm the families and communities in which victims live. 


\section{Defining the Subject: Criminal Violence}

My central concern in this book is with justice for criminal violence, what police call crimes against the person. These crimes involve the wrongful application of force or the threat of such force to the person, as in murder, robbery, rape and assault. I also include here all culpable violations of sexual autonomy. Sexual violations may be accomplished by direct force, as in most cases of rape, or by other forms of coercion such as exploiting differences in age and power, as, for example, in adult sexual contact with children. In this book I look at sexual violence and nonsexual violence, fatal and nonfatal attacks, domestic violence and stranger violence, because although there are many important differences between these wrongs and the harms inflicted, there are also important continuities in the moral and spiritual challenges they present.

All forms of criminal violence threaten the body, the inner person or both. Usually both. Many forms of criminal violence involve an explicit or implicit threat of death. This makes the experience traumatic and threatens the soul. In the case of sexual violations accomplished without threat to life, there is still an invasion of mind and spirit. Acts of sexual violation force intimate experiences on the person, changing the person's nature against his or her will.

Although my subject is criminal violence, I will also call it wrongful violence, and sometimes, as I have already, speak simply of violence. Although this risks confusion, I want to avoid hasty moral judgments. Once conduct is labeled criminal, moral disagreements disappear, or seem to. Who supports criminal violence? Yet we often disagree about what should be labeled criminal and what makes it wrong, where it comes from, who is responsible for it, and what we should do about it. Instances of purported self-defense, police use of force and controversies about nonconsent in rape are a few central examples. I want to make sure that the label of criminal does not stop us from seeing important moral issues.

There is a downside to considering all forms of criminal violence here. There is so much variation in circumstance and intent. The experience of victims varies widely according to the nature of the violence and the individual's personality and past history. Some persons survive horrific events and seem to go on relatively unscathed. They are enormously resilient. Others may be shattered by much lesser forms of violence. Different kinds of violence have different impacts. The experience of a victim of sexual violence is different than someone surviving the murder of a sibling, child or partner. And yet I think there are sufficient common denominators across different kinds of wrongful violence to make their omnibus consideration here worthwhile. 


\section{Harms to Body, Harms to Spirit: Two Stories}

We begin our look at wrongful violence with the basic challenge of understanding its harms. This should sound strange, like trying to understand the harms of cancer or bigotry. Aren't these obvious? I will argue, though, that what we as a people understand in a general way we also understand only superficially. We can easily miss - we often do miss - the moral and spirit harms suffered by the victim of violence. And if we miss or misunderstand these critical aspects of the victim experience, then our conception of justice will be faulty as well.

To illustrate the moral and spirit harms of wrongful violence, I offer two fictional, but realistic stories of violence to a child.

First Story. A six-year-old boy gets up in the morning and wanders into the kitchen, still in his Superman pajamas. He's hungry. He knows that if he wants any breakfast that he will have to get it for himself. He reaches up into a kitchen cabinet and gets out a glass for juice. He takes a gallon container of orange drink from the refrigerator, but it is too big and heavy for him, and in trying to pour some into the glass, he knocks the glass onto the floor where it shatters and juice spills everywhere.

The noise brings his father to the kitchen. In this account, I will imagine that it is his father, but it could equally be the boy's mother, or a stepfather or stepmother, grandparent or some other caregiver-what is important for the story is that this adult is a parent figure for the boy, who is supposed to care for him.

Imagine that the father, infuriated by the boy's clumsiness and the mess made, with a full swing of the arm smacks the boy in the face with an open hand, sending him crashing headfirst into the kitchen table. He suffers a cut and facial bruising. The father then walks away.

This event can be analyzed from a social perspective, from a psychological perspective, from a cultural perspective, a gender perspective. Each of these will be important to understanding and responding to the event, but none will suffice unless we also consider it from a moral perspective. What happened here is wrong. But what kind of wrong?

In the past, violence like this against a child which did no lasting physical harm was seen as a private matter because it concerned the domestic discipline of a child. Family members or neighbors or other community members might have criticized the father for his brutality, but the incident would not have drawn the serious attention of the police or the law. In effect, the community condoned such violence. It is one of the more important changes in American society that today many kinds of violence in the home previously ignored have become matters for serious criminal investigation, prosecution and punishment. 
Removing such violence from private protection and making it a public matter represents a change in both public morals and legal practice.

Second Story. To illustrate the spirit challenges of violence, imagine the same kitchen accident, followed by a different adult response. The father, infuriated by the boy's clumsiness and the mess made, says in a biting tone: "You little piece of shit. You're never going to amount to anything, you know that? You're always going to be fucking loser. And don't even think about crying."

Unlike the first incident, this conduct is not criminal today. However hurtful the words, no physical injury has occurred. Under contemporary law, these words are just words. The father may be criticized by family members, and by others, for verbal brutality, but that will be, in most cases, the end of the critique. When it comes to parental discipline, the criminal law draws a line between the use of force and the use of words.

But consider, for a moment, these two events from the child's perspective. For a child who might have experienced both, which would have been worse? The first was physically painful; the second was not. The first was frightening in a way that the second was not. And yet to a child's spirit, the vicious words might strike harder and the hurt might go deeper than the blow. Victims of child abuse and domestic violence often say that however bad their physical injuries, the insults flung by their abuser hurt more.

Precisely because there was no physical injury in the second story, we can see more clearly the spirit harm inflicted there. The words were spoken with harmful intent. They were meant to cause emotional injury, and almost certainly did. The adult declared the boy worthless. The boy was (verbally) rejected as a person by one who was supposed to care for him unconditionally. This was a moment of profound devaluation and exclusion from belonging.

Now return to the experience of the boy in the first story. He suffered physical pain and fear of injury in the incident. But he was also hurt, we can easily imagine, by the message delivered by his father's blow. In that hard slap the boy learned that he did not count for much. Accidentally smashing a glass was enough for him to be deliberately smashed by his dad. As a result, the boy's spirit suffered, just as in the case of verbal abuse. The boy suffered a similar injury to self-worth and experienced much the same sense of isolation and injury to trust. Where there is a physical assault, as here, the spirit harms of violence can easily go unnoticed. The spirit harms may do more damage, however.

The boy struck by his father will grow up to be a man who knows violence in his bones. This is one of violence's terrible lessons. Especially if the abuse experience is repeated, he will know a great deal about violent threat-what it feels like, how sudden it can be, and will know something about how to 
defend body and soul against it. He will have learned, very early, that no one can be entirely trusted. The young man may grow up with a great store of anger seeking release, and a highly developed sense of personal danger that makes him much readier than others to perceive threat and respond with violence. He may become a man whose sudden rages and explosions of violence surprise even himself. None of this is inevitable, but the chances of his becoming a man prone to violence increase greatly with childhood experiences of violence. This includes the experience of seeing violence done to others. ${ }^{5}$ The man of today was shaped by the boy who was traumatized. We cannot understand or effectively address the man's present violence without seeing and appreciating the moral and spiritual hurts of his youth.

From this we can see why the moral and spiritual dimensions of wrongful violence are critical to understanding what a just response to such violence might be. The right must match the wrong.

\section{Listening to Victims: Emotional Effects}

From these introductory accounts, we turn to actual victims and their voices. We listen for their experience. We begin with the emotional dimension of their experience, with the numbness, fear, anger, and sadness that violence often provokes.

\section{Numbness}

Severe physical trauma often produces a shock response. Important body systems, including the nervous system's reporting of pain to the brain, shut down in order to preserve essential functions. An injury that we would expect to produce excruciating pain is, for a time, hardly felt. Violence can produce the same effect on the survivor's emotions: a shutdown of basic feeling that renders the person emotionally numb. A police chaplain speaks of those with "homicide eyes": a look of hollowness and disconnection that signals emotional numbness. ${ }^{6}$ Numbness, like physical shock, may wear off, but even if it persists, emotional numbness should never be confused with a lack of injury. It actually signals the opposite.

\section{Fear}

For those who survive violence, fear often dominates daily life.

"I have spent countless hours terrified and nauseated like a scared rabbit," states a young woman who escaped an attempted abduction while jogging. Her fear is 
compounded by the knowledge that the man who went after her later raped and killed two teenage girls. ${ }^{7}$

"I have trouble enjoying a quiet drink with my partner, family or friends without feeling anxious and wary. I am constantly looking over my shoulder fearing there is someone there who wants to hurt me." (A rape victim.)

"The world is darker to me now; I am more nervous when I go out. Who knows who else is out there somewhere who could change so drastically? Maybe anyone could." (A man speaking of his life after discovering that his own brother had gone on a killing spree. $)^{9}$

\section{Anger}

Fear's twin is anger. Often at sentencing victims express great anger at perpetrators. We hear victims call for the worst suffering to be rained down on the perpetrator, not just in this life but in the hereafter.

Alice Sebold who wrote a memoir of her rape and recovery, recounts that her hatred for her rapist sustained her during his prosecution. "In my mind, the rapist had murdered me on the date of the rape. Now I was going to murder him back. Make my hate large and whole." ${ }^{, 10}$ In preparation for testifying, she wrote on her leg beneath her skirt a message to the defendant: "You will die." 11 An important stage in her recovery was writing a poem that she addressed to her rapist, graphically describing how she would destroy him "with boots and guns and glass," among other weapons. ${ }^{12}$

At sentencing, surviving victims and family members often express great anger at the defendant. For example, here are several family members excoriating Scott Peterson, who was convicted of killing his pregnant wife in a highly publicized case in central California, addressing him in court: ${ }^{13}$

You are a sick person with no heart, and you will pay for what you've done, and you deserve everything that's coming to you. The only comfort I have is knowing you will be suffering every day for the rest of your life until you die, and no punishment you receive on earth will ever compare to the punishment that God will give you once you die.

(Amy Rocha)

Scott, you're a real wonderful man, you know that? A piece of shit is what you are .... Boy, I tell you, you're going to burn in hell for this, too; I tell you, you are. You know, you're not going to lie to God. You're going to be just sitting there in your cell. No more golfing. You know you're not going to golf no more? You're not going to go to dinner. No more women. You 
know, your life is done for. I hope you realize that. You're going to realize. And you're going to burn in hell for that, too. I've got no more to say to you.

(Dennis Rocha)

You're selfish, heartless, spoiled, self-centered, and you are a coward; but above all, you are an evil murderer. You murdered my beautiful Laci and her precious baby Connor, my grandson. You murdered your own baby. You're a baby killer. Not even Satan will claim to have a part in your making ... You could have chosen to change your path and distance yourself from evil, but you didn't. You Scott, have proved that evil can lurk anywhere. You don't even have to look evil to be evil.... And now, Scott Peterson, I'm saying this to you: You deserve to burn in hell for all eternity.

(Sharon Rocha)

\section{Pain}

And of course there is in the wake of violence, pain. Survivors must live with the deep and lasting pain of terrible loss.

A father describes the pain from the loss of his adult daughter, who was murdered by her abusive husband this way: "I cry every day. It is a struggle to get through every day. I wake up with the pain, carry it through the day, and take it to bed with me each night."14

A mother speaks of her pain following the kidnapping of her 11-year-old daughter: "I could hear her crying, but not with my ears, with my heart. I could feel her pain, not with my body, but with my heart. I endured a huge gaping hole in my heart, that some evil being put their hand in and ripped it out." 15 Her daughter was held in captivity for 18 years.

"The pain I felt was so deep that it felt like the worst thing on the face of the earth. Imagine the hardest emotional moment you've ever had in your entire life, and multiply that by 200 ... It felt like it would never end." These are the words of a first responder to the Boston Marathon bombing. ${ }^{16}$

This pain is not transitory. Although others assure them that time will heal their wounds, many victims find that their pain is permanent.

"Our pain is not a state of being but a condition of life. We live with this hole in our family, our heart, our belief, and our lives." 17 This is taken from a letter written by a family about the loss of a family member to a drunk driving accident.

A mother, speaking to her doctor about the murder of her daughter more than 30 years earlier, confesses: "I love my other children and their children, but this is always in my heart and mind. It never leaves me."18 


\section{Reading Victim Emotions: Harms to Identity and the Soul}

This account of emotional responses to violent crime contains no major surprises. Everyone knows that victims suffer both physically and emotionally. The surprises come when we explore the meaning of these emotional responses.

Feelings signal personal importance. If something really matters to us personally, we will feel it emotionally in some way. The emotional response may be complicated and our understanding of it imperfect, but the fact of emotion-even sometimes the fact of unusual nonemotion - shows that the triggering event matters to the person.

Clearly violence matters enormously to its survivors; we can see this in the extremes of their emotional responses. We can also see this in the way that emotions get triggered for years to come. Victims find that anniversaries of past violence bring awful emotional burdens. The person may think, why am I feeling this way? What is this ache in my bones? Why is my heart so heavy? And then the realization comes that one is approaching the birthday of a loved one lost, or the anniversary of the event itself.

War veterans often find themselves reliving experiences of 50 or 60 years earlier. I have heard my father-in-law describe on more than one occasion his experience soon after World War II, when he worked for a time at camps for displaced persons in Eastern Europe, sometimes located on or near the sites of former concentration camps. Among the Holocaust survivors still held in the camps then were teenage girls and young women who had lost all family. They had no one to go home to. Emaciated by starvation, often bloated by malnutrition, they were desperate for a savior. He can remember clearly them reaching out to him, a young single man, asking: marry me. Save me, take me to America. This image of the violence done by the Nazis against the Jews remains for my father-in-law powerful. Into his late 80 s, it so haunted him that he recounted it often.

For women, pregnancy and childbirth are experiences that can bring back memories of sexual wrongs, long forgotten or repressed.

Even long after the fact, even years and decades after the fact of the violent event, violence matters deeply to those who survive it. This indicates that there may be more going on with victims beneath the surface of present appearances. Strong emotional currents-and dangerous ones - run below the surface.

A question: Why do strong emotions persist even long after violence which a person survives? There is a physiological answer having to do with the way trauma affects the brain. But I am concerned with the human meaning of this phenomenon. I take it as evidence of fundamental personal change. The person who survives violence is not the same person who lived before. There has been a kind of death, an erasure of a prior identity. She also suffers a great harm to the soul. 


\section{Harm to Identity}

In one of Franz Kafka's most famous stories, "Metamorphosis," a man wakes up in the morning to discover that he has become a giant insect, a cockroach. ${ }^{19}$ Though told in matter of fact tones, the story is utterly bizarre. On some level, the reader realizes this could never happen, and the author never tries to explain how it could. And yet something about the story makes sense because we can be suddenly and fundamentally changed-against our will.

Survivors of violence experience a kind of metamorphosis. Many survivors report a strange and entirely unchosen alteration in self-identity. They describe looking at the face in the mirror and wondering who she is. Where did this person come from? Who is this person plagued by fear? Who is this person full of anger? Who is this person who despairs? Who is this person with a totally different perspective on the world, a different personality?

Rape victims are particularly eloquent on identity change due to violence.

That man stole ME from me. He ripped my personality out of me-who I was- the same as if he had ripped out my heart. ${ }^{20}$

My name is Jessica. I once knew what that meant. Now all I can tell you is that I am still Jessica, however this no longer holds any meaning to me. I have lost my identity in the cruellest of ways ... I was raped. ... I am no longer the person I was before. I was once the person that people could rely on. Now I am a shell of my former self, a speck of the brave person that was Jessica. I had my way of life, my self-esteem, my respect and my dignity stripped from me in the most terrifying of situations. My trust in people is all but destroyed. ... My motivation is gone. My joy of motherhood is waning. My ability to love and care for others is disappearing. $^{21}$

It's not just the act [of rape] it's what follows, it's like a virus that infects your heart, soul and mind, and it's contagious and infects everyone close to you and when you look into their eyes you can see that they are looking back at the shell of a person they used to know. I don't blame them, I see the same when I look in the mirror. Who am I now, what am I now, who will I become. I was never much of a fan of the old me but I wish I was her again. $^{22}$

The loss of a loved one to homicide can have a similar effect on survivors:

The day Lexi was killed has forever changed me, devastated me. The flame [of life] I spoke of earlier is now just a flicker, barely lit and only fueled by my remaining 
children. They have lost the mother I was before the fateful night Lexi lost her life. My husband Todd has lost the carefree loving wife he married. My parents have lost their strong caretaker. My friends have lost the fun-loving friend they once had. ${ }^{23}$

This is the voice of a mother whose daughter, Lexi, was killed by a drunk driver.

Surviving violence can be deeply confusing because of the way that it alters selfidentity. While it appears that the victim has survived intact, the victim knows that the person he or she was before is gone. The survivor must become someone else.

A kidnapping victim: "When I describe what happened to me, I say that I was taken." ${ }^{24}$ Prefacing the description of her kidnapping, she writes: "This is how one life ends and another one begins." 25

Addressing the man convicted of murder in a multi-fatality drunk driving accident, the mother of a victim declares: "Andrew Gallo, the night you killed my daughter you killed me ... I will never be the same."26

"Yes I survived. Yes I am alive, I just don't live. I am existing. I am empty.",27 (A rape victim.)

A sense of who one is critical to a full life. How can we know the world around us, how can we know others, how can we know what we are supposed to do if we do not know ourselves? A strong self-identity therefore should be treasured and defended. Its loss can be devastating, especially for the young who are so heavily engaged in the work of building their own identities.

The question becomes why victims are so changed by their experience. Why should something that happens to a person-is not chosen by the person-have such an inner effect? It's one thing to change identity through a chosen process. Someone who trains to become a police officer, or a student who studies three years in law school to become a lawyer, is likely to adopt new values and ways of thinking that may change their sense of themselves. That does not surprise. It seems natural because the change stems from the person's voluntary choice. But to have this happen, and on a profound level, because of the unchosen acts of another? That seems strange. And deeply troubling. Somehow criminal violence, an external event, wreaks internal havoc. According to many victims, it harms the soul.

\section{Harm to the Soul}

Again, hear victims speak.

A woman who was raped by a priest when she was an eighth grader: "I can't explain the pain because I'm still trying to figure it out, but I have an emptiness where my soul should be." 28 
"It's as though the moment I was hit ... I was cut off from myself-as though all my connections to the world were slashed.",29

I believe that it was soul injury that I saw in the black holes of that grieving husband's eyes in the North Florida courtroom. He had done nothing to incur this. His wife had done nothing to make herself a victim. But when she lost her life to murder, it appeared that he lost the best part of his life as well.

The nature of soul harm can be inferred from the lives of the most hurt. We have seen that violence can make the person numb. Emotionally, nothing gets through. Nothing seems to matter. This is why in the wake of violence we often see the hurt-especially the young-trying to raise the volume and intensity of their emotional lives in order to feel again. Like someone who has to shout over the din of a crowded bar to be heard, the person who cannot connect in ordinary ways must resort to extreme methods to feel engaged with life. Some victims provoke conflict with others. Some engage in risky behavior. In these ways they feel more alive and more (relatively) in control. Some become sexually promiscuous, substituting physical connection for love. Victimization can create a distrust of others that makes more constructive ways of connecting to fellow human beings untenable. Real intimacy requires a faith in others that a souldamaged person lacks.

For some victims, sober life is too painful so they drink and drug as a form of self-medication. Intoxication provides at least a temporary escape from internal hurt. Intoxication may also provide excitement and pleasure not available any other way. In effect, it substitutes for meaningful relations with others.

Looking at the long-term substance abuse, the ill-considered sexual relationships, the extremes of depression and mania, the social isolation and the sheer unhappiness of many victims of violence, an observer may wonder, what's going on? What kind of demon drives a person to such self-destructive and apparently pointless acts? But it is not a demon we should blame, but damage to the soul which produces a brokenness and internal chaos that is expressed in often selfdestructive behavior.

The basic ability to find meaning in life is affected. Positive events no longer evoke positive feelings. The concern of others, no matter how sincere, may be rejected. Victims, especially of sexual violence, believe: Nobody understands. How could they? Friendship and romantic love seem difficult, if not impossible. No one could really like me now. Meanwhile, activities that should be shunned as dangerous and self-destructive, now appear attractive.

In Chapter 8 we will see how victims can heal from soul damage. There are ways to find meaning again, to belong again. For now, though, we need to learn more about this thing called soul. 


\section{The Soul: Definition and Function}

Victims speak about soul harms to express the depth of their injury. Because they speak of the soul, we should as well.

The soul is at the center of what makes me me and you you. It is essential to personal identity. Because it is so fundamental to who we are, threats to the soul inspire enormous fear. A threat to the soul is a life and death crisis for the person.

The word soul has many different meanings according to different cultures, religions, philosophies and eras. The problem of its definition goes beyond even these many variations, however. The very concept defies precise articulation. The power of the word soul lies as much in what it connotes as what it denotes. Like talk of love or beauty, soul talk draws from highly personal experience. It cannot be objectified. And yet some definition is required for a sensible discussion.

Let's start with how we normally talk about souls. We may hear it said that a person has lost his soul to drugs, or to money or power. Or that a school or nation has lost its soul. In each instance the speaker means that the person or entity has betrayed essential values and therefore lost a previous, highly valued identity. For example, a once generous institution has become greedy, a freedom-loving nation has become autocratic, a peace-loving people has turned violent.

For individuals, the soul is the center of personal identity. Your soul belongs to you; any effort to control the soul by another represents a grave moral and spiritual transgression. Hence the ancient idea of damnation by selling one's soul to the devil. Or, to use a modern illustration of the same idea, child abuse has been called soul murder because of the way that the abuser takes ownership of the inner child. ${ }^{30}$ To lose one's soul means to lose oneself. It means losing the person's basic value: that which she has (or had) to give to others. Recall how victims speak of their loss of self. It's as though the moment I was hit ... I was cut off from myself-as though all my connections to the world were slashed ... My rapist stole me from me ... I lost my identity in the cruelest of ways.

The soul would seem to be a distinctly private part of the person, encompassing as it does the innermost self. However I may seem to outside observers, my soul contains my true self. This suggests that I can defend my self (my soul) from outside interference. But that's only partly true.

Who I am (my identity, my self) comes from the interchange between my self and others. I can block or severely restrict these interchanges, but only at great personal cost, because social interaction is vital to the soul's work. ${ }^{31}$ The soul's job is to connect with other souls. This is how we find meaning in life.

Psychiatrist Viktor Frankl wrote years ago that we human beings are meaningseeking creatures. ${ }^{32}$ We seek a purpose to our lives. Meaning is what makes human 
life worthwhile, what makes it a life and not just an existence. Meaning makes life good. Meaning is what can stand up to mortality. If you knew you were to die tomorrow, which of your relationships, which of your accomplishments, would seem significant? Standing in death's shadow, which would seem important and which trivial?

The soul helps us live in the face of death. Death comes for us all at some point, threatening personal oblivion (no existence, no-self) and meaninglessness (given death, how does any of this matter?). A healthy soul, by generating meaning, gives us the sense that life has a purpose despite its inevitable end.

The soul is the metaphysical but nevertheless very real organ that generates hope despite death's reality, and trust in others, despite their many proven shortcomings, excesses and cruelties. Losing one's soul is synonymous in most cases with losing hope and trust, thereby losing the ability to find meaning in a life. Hear again what victims say about the soul. I have an emptiness where my soul should be ... He ripped my soul out of me ... Yes I am alive, I just don't live. I am existing. I am empty.

\section{How Violence Attacks the Soul}

The fear, anger, sadness - even the numbness - that victims of violence suffer show how they have been hurt. Witnesses to violence may also suffer this way. There has been injury to the inner person, to the soul. The question is how. How does violence do such damage to the inner person? How does it harm the soul?

Sexual violence provides some useful insights here. Sexuality is a critical aspect of self-identity, almost regardless of age. Sexuality helps define where we stand in the human world. Becoming sexually intimate, the body and spirit of one person may connect, at least for a time, with the body and spirit of another. We presume that this connection requires consent, however. Great harm may follow-almost certainly will follow-if consent is absent.

More than ever before, individuals in the United States have the freedom to choose their own sexual identity. Rights of sexual autonomy are increasingly protected by law and culture. Crimes of sexual violence are taken seriously today in a way they have not been before. Still, violence can override choice, and frequently does. By forcible sexual contact, an unchosen intimate connection can be made between two persons.

There is a horror movie aspect to this dynamic. Imagine a malevolent scientist who can invade the mind. He can damage not just the body but the inner person, and this damage can never be undone. 
The perpetrator of a sex offense in fact does invade the self via forced sex and can do lasting harm to the soul in the process. By commandeering the sexual connection, the offender forces his or her way into the soul via the body.

Something similar can happen in nonsexual violence. Serious violence threatens death. Recall that the soul helps us find meaning in life, allowing us to live in the face of death. This requires trust in others and trust in survival, at least for the near future. By threatening death, the attacker smashes these structures of trust. The victim understands that she may die now, and for no good reason. Surviving such an attack produces relief at survival, but the experience of existential horror remains lodged in body and soul.

Sudden threats of death to oneself or a loved one, or the killing of a loved one in an attack, these threaten the soul's ability to stand up to death. They strip the soul naked, to stand apparently helpless before the looming void. What is the point of life if its good can be taken at another's whim?

In many cases, wrongful violence destroys treasured relationships, leaving the soul and its connections bereft. Like a tree that has lost a major limb in a storm, survival may be possible but not with the flourishing of before.

In suffering wrongful violence, the soul also suffers grave moral injury. Evil seems to have triumphed. Its apparent victory raises a question that haunts the organ of trust and outreach: is there truly good in the world? Is there good for me, for the ones I love? This often turns on whether the person feels that she belongs in the world. Violence attacks belonging, which is why its harms go deep. Harm to belonging also constitutes part of the revelation of violence, though. The basic need of all humans to belong means that we must take seriously our own actions that devastate others' belonging, such as imposing long terms of incarceration.

Once we appreciate the essential human need to belong, and how much our daily lives are structured by it, it becomes more difficult to swear full allegiance to the idea that we are all entirely independent actors and need never take account of social context or social structure in responsibility determinations.

\section{The Soul's Work and the Human Need to Belong}

Human beings are social creatures. The evidence is all around us- the ubiquity of social media, sporting contests played out to hundreds, thousands, millions of fans, the collective enterprise of political parties, religion, nationality; the power of the family unit. The social nature of humanity is obvious to social scientists and lay people alike. What can get missed in the social dimension of human life, though, is the spirit need that lies behind much of social activity: the need to belong. For all 
our celebration of individuality in America, most recognize that to have a good life, one must find a place of belonging, however small.

We are made to belong to others. Husbands belong to wives, children to parents, brothers and sisters to each other. We may belong to work and social communities, to tribes and nations. ${ }^{33} \mathrm{We}$ belong to political parties, to cities, to regions. In giving our allegiance to sports teams, whether school or professional, we express a need for belonging.

To truly belong means to be seen and valued. When we belong, others see us for who we are and value us for being ourselves. At its best, belonging means being accepted for who we are and not for what we have done. Ideally, belonging means that we are cared for. At a minimum, belonging means that we matter to others.

The most basic image of belonging is that of a mother cradling her newborn child in her arms. The child belongs to the mother and the mother to the child. The child is loved just for being who he or she is. The mother's love is unconditional. The science of human development tells us that the entire course of a life can be affected by the experience of belonging in infancy. If mother and infant become attuned to each other, physically, emotionally, mentally, in the first six months of life, the child will have a secure emotional foundation that will provide emotional resiliency in years to come. A failure of attachment during this time will have lifelong negative repercussions.

Violence attacks belonging. Remember the boy who was struck, physically or verbally by his father, and his spirit injury. In both scenarios, the father expressed disregard for the boy. Whether in a blow or words, the father declared the boy's worthlessness at that moment, a declaration that is the essence of not belonging.

Surviving victims of sexual offenses often feel as if they have been taken from the realm of belonging and rendered somehow alien to human society. In cases of homicide, surviving friends and lovers and family members suffer the traumatic loss of a valued life and critical relationship. The loss can be so profound and so disturbing that it threatens the ability to make and maintain caring relationships with others. This is why the response of friends and family and community to violence is so critical for victims. The values attacked by violence must be collectively affirmed. This is part of what the surviving husband in the North Florida courtroom sought to do: to show that the trashing of his wife by a homicidal teen would not stand.

\section{The Battle over Who We Are, Really: Rival Views of Identity}

Victims report, over and over again, that others do not understand their experience. Nonvictims do not comprehend the loss that victims have suffered. Why is that? 
Lack of understanding may come from lack of information. People need education on the spirit harms of violence. We have seen major advances in this regard with respect to sexual violence and domestic violence, but still denial and avoidance prevail. Discomfort with the extreme spirit pain — really the agony—of victims leads many to avoid full appreciation of the hurt. It's hard, and may not seem necessary to stay with victim pain long enough to comprehend its nature. We all have to live our own lives in the end. Right?

Another major obstacle to comprehending soul harm is the predominant American view of personal identity. We Americans like to believe that identity is selfcreated and can be defended against all comers. Other people may urge you to change, entice you to change, even threaten you to make you change, but the strong person, the good person will resist. She will not lose her essence, her soul, to either threat or temptation. This we believe.

This violence denies.

\section{The Autonomy Ideal: Americans as Fiercely Independent Self-Choosers}

Americans have long celebrated (at least in principle) every citizen's ability to choose a course of life free of any constraint except the most basic one of refraining from actively hurting others. America sees itself as a nation of strong individuals not beholden to monarch or nobility, free of class restraints, unfettered by family ties. In America the individual - the autonomous self-is king.

The autonomy ideal informs national public policy in many areas, including health care, gun regulation, and criminal punishment. The ideal suggests that the government should give persons maximum space for the free exercise of individual autonomy. But if individuals abuse their freedom (autonomy) and harm others through unlawful acts, they must be punished. Their free (and therefore fully responsible) choice to violate the law makes them deserving of moral and legal condemnation.

The autonomy ideal holds that a person is and should be treated as an independent, fully responsible agent regardless of relationships or social context. The presumption is that once a person has grown up (and of course there is much room for debate about what that means) he or she becomes a fully independent actor with a distinct personality and values that remain essentially constant regardless of situation. The person is who he is and is responsible for all he does, regardless of what others desire, say or even do. The autonomous individual may be knocked around by others, but that will not change his inner person, his true self.

Autonomous individuals protect their inner selves with outer armor. Like hardshelled creatures, they are largely impervious to their social environment, at least as 
long as they wish. Being human, they can open their inner selves to others, when they want. Then close emotional connections can be made.

The autonomy ideal is not explicitly gendered, but it powerfully connects with traditional constructs of masculinity and femininity. The man is hard on the outside, making him a thoroughly independent social actor. By contrast, a woman is expected to be soft on the outside, allowing her to connect emotionally with those around her. This makes her identity much more dependent on relations with others.

Under the autonomy ideal, individual identity is largely fixed; it does not change according to social situation. For example, supporters of a defendant at sentencing will often tell the judge that the defendant is a person of good character, inconsistent with the crime of conviction. The supporter will often say something like: "Your Honor, I have known __ for 20 years and as far as this charge is concerned, that's not the __ that I know." The supporter may go on to say: "She's just not like that. She wouldn't do that." The presumption is that someone who is respectful and caring in one situation will be respectful and caring in another. If a person has always told us the truth, we don't think he will lie to others.

Especially dramatic examples of the autonomy ideal may be found in popular American culture. A classic example is the hard-bitten, unnamed gunfighter played by Clint Eastwood in his 1970s spaghetti westerns (High Plains Drifter, Hang 'Em High). He is a man of few words who comes into town a complete stranger, and despite many violent and occasionally intimate interactions, remains a stranger. He is violently challenged, but is never defeated and never, in any important way, changed.

Other personifications of the autonomy ideal can be found in the protagonists of innumerable crime dramas: the detective, the street cop, the private investigator, or the civilian-turned-avenger who brings wrongdoers to account. The hero (who is often disguised as an antihero) bends or breaks the rules to do justice. He (usually he, though occasionally she) disobeys the orders of more powerful individuals who refuse to do what is needed for justice. The powerful refuse to do what is right in order to preserve what they have, but the hero-and this is what makes him the hero-follows his own true values, regardless of social consequences. He defends his own essential self, even at great personal cost.

Under the ideal of autonomy, relationships can be wonderful, but they need to be freely chosen. Choice is paramount. The fully autonomous person decides whether he or she wants to be in relationship with another. Not being in relationship, and therefore not belonging, is always an option. The lone protagonist of crime dramas often takes this lonely path, eschewing belonging (mostly) to do justice. ${ }^{34}$ 
The world of self-help provides another window into contemporary ideals of autonomy. Many self-help presentations rest on the idea that you can decide who you want to be. You may have been fat all your life, but you don't need to be. Just consider yourself to be a thin person and that is who you will become. Similarly, you can remake yourself to be popular, to be successful, to be rich. It's all in your own control. And if you encounter doubters, if you face detractors, ignore them. Do not let yourself be the victim of others. You're not a victim unless you choose to be.

In subtle but important ways, the autonomy ideal shapes how we may see and respond to the spirit harms of violence. The autonomy ideal focuses our responsibility attention on individual actions. Those who commit crimes should be convicted and punished. As for the healing of damaged souls, that lies outside the purview of the law, and may also go beyond community concern. Victims should stay tough. Refuse to succumb to the perpetrator's spirit intrusion. As soon as possible, they should move on. That will be hard, of course, but like every other autonomous person, victims control their own souls. Or so we like to believe.

\section{The Reality of Relational Identity}

The autonomy ideal is not reality. It exaggerates how much we can control relationships and therefore how much we choose our own selves. We do make important choices about personal relationships and these choices help shape our place in the world, but there are serious limits to self-determination, limits that we miss at our spiritual peril. The autonomy ideal also exaggerates the extent to which each of us has a singular, invariant character or identity, as opposed to an identity that may shift with social interactions. ${ }^{35}$

I have always been an introspective person. Even when quite young, I thought a lot about who I was and how I was perceived. As a boy I can remember, at night, thinking over my interactions with other kids and grownups during the day. I can remember trying to devise new schemes for what I called "foreign affairs," using the term that I had heard on the nightly news. This meant coming up with a plan for how I would relate to others. I believed that with the right strategy, I could, like a sovereign nation, improve my standing in the world. I wanted to avoid a repeat of past social humiliations and become better liked and respected. My plans were generally flawed, however. With some frequency I resolved on a strategy of social withdrawal, being present but largely silent, believing that this would protect me from potential slights, and eventually impress others with my independence, resolve and depth. 
As you might expect, this brought few positive results. This was no Marshall plan, no Monroe doctrine. Pulling back is not a good way to connect, which is actually what I needed to do.

To the extent I did as I had planned, I managed to increase my social isolation along with my social anxiety. Still my fundamental mistake was not the particular strategy chosen, but the belief that I could manage social relations by my own decisions alone. It was the idea that I, and only I, would decide who Sam was going to be. That seemed to be true. That's what the experience of consciousness supported. But it wasn't true. You can't control a complex set of relationships by controlling just one party to them.

The experience of important friendships in high school, meeting the woman who would become my wife in college, and most of all, becoming a dad in my 30 s, helped me to see the importance of the unchosen and unpredictable in relationships and therefore the unchosen and unpredictable in personal identity. I became a father to two girls who had distinctive personalities and needs, to whom I owed the greatest of all responsibilities. I loved (and love) my children enormously, and with such love comes soul-power, on both sides of the relationship. As a parent, no one can bring you up, or take you down, like your child.

Although my wife and I chose to have children, we hardly chose what happened next. Children come with surprises. The needs of my girls changed who I was. They allowed me to be funny in a way that I rarely am with adults. They laughed when I parked the car bizarrely (hey - they thought it was hilarious) and also when, during the bedtime reading of yet another Little House on the Prairie book, I improvised quick visits to outer space to provide a break from cooking and sewing adventures. (And yes, this did provoke some protests as well.) With my children I could not indulge my darker moods as I had before. They still happened, and unfortunately still affected the family, but I worked hard to stay present because that's what parenting demands. Fatherhood taught that I was not fully in charge, even of my own self.

Another way to understand the relational nature of identity is through nationality, gender and race. These are important, relational features of identity. I cannot be an American, a person who identifies as a citizen of the United States, except in a world that includes Mexicans, Tanzanians, Chinese and other nationalities. Gender is similar. To declare oneself a man or a woman is to see oneself in relation to the opposite gender. Same for race. The race categories of black or white do not very accurately track individual characteristics of skin shade or color. ${ }^{36}$ They primarily designate membership in one socially constructed group as opposed to-meaning in relation to-another. If other racial groups are not present in the society in significant numbers, then race fades in importance to identity. 
Relational identity is only partly chosen. I am an American by birth. While some people change their national allegiances, for most, national identity comes from their parents or birth place, neither of which they chose. Gender and race identities are similar.

Or consider the people we call our relatives. Who can say that who we grew up with, or who brought us up, did not have a lasting effect on who we became? Look at how much birth order influences adult roles and outlook. Family relationships are clearly formative. Yet they are not, for the most part, chosen. As the popular saying goes, you can choose your friends, but you can't choose your family. You cannot choose your parents, grandparents, siblings, extended family, or in-laws. As an adult, we can choose to move away or otherwise limit interaction with relatives. This does not mean we have severed emotional connections with them, however. They may still be important to who we are.

Finally, what about this notion that individual identity is basically fixed, and does not change according to relational situation? Again this does not seem to reflect human experience.

It's true that we are often disturbed or even offended when we see someone who seems to change according to social situation. We associate such flexibility with the deceitful and predatory: a con man, or the worst sort of politician. In the romantic realm, the seducer becomes blameworthy to the extent that he adopts an alluring persona just to win another's affections.

And yet we expect people to act in differently in different social situations. Witness the same person at a gathering of old high school friends, at an office meeting, at a family birthday party. See how much changes when the setting is single-sex or mixed. There is nothing strange or untoward here. The differences can be explained by the different social dynamics and expectations of each situation, which is my point. The expectations of others, the unwritten rules of social interactions, they change our behaviors and, in a very real sense, change the self that we present. That self is not inauthentic just because it differs from what we might say and do in other social situations. There is more variety to the self than we normally acknowledge. We are different people, to different people, according to relationship.

A teenager may be a loving son to his mom, a great brother to his sister-and still murder a rival gang member in cold blood. The hedge fund executive may be a successful businessman, with a well-earned reputation for integrity among friends and family, yet commit serious violations of federal law in his trading practices. People change behavior according to social context.

Relational reality diverges most from the autonomy ideal, and its truth is hardest to accept, with unchosen, negative relationships. The idea that people who do not 
like you and do not wish you well may affect not just your physical situation but who you are, is very difficult to swallow.

We can easily accept the idea that who we are today is shaped by past positive relationships. What autobiographical account of a President, NBA star or Nobel Prize winner would be complete without a few hagiographic mentions of past mentors, of parents or grandparents, uncles or aunts, teachers or coaches, who helped shape the author's character? Sometimes negative relations are cited as inspiring the individual's drive to success, but otherwise these are not much discussed. Who wants to admit that she or he is the product of unchosen, destructive interactions with others? Who wants to admit that in some critical ways, they still belong to people who have done them harm?

The experience of victims of violence shows that who we are always depends on our relations with others. It shows that these relations may be chosen or unchosen, wonderful or ugly. Usually they are a mix of chosen and unchosen, good and not so good. The point is that all these relations shape who we are.

In the next chapter the significance of relational identity for moral responsibility becomes clear. Because we are relationally connected, in our interactions we may hurt others without conscious intent. Institutions and government may do the same. To avoid serious harm-doing requires an affirmative effort to see the particular person with whom we interact and to care about their most basic good. In this way the truth of relationality may change what it means to be culpable- to be morally responsible-for harming another person.

\section{Conclusion}

The most dangerous ignorance may be when we believe we know what we actually do not. You live or work with someone for years and, as a result, you quite reasonably believe that you know them. You know their abilities and shortcomings, their hopes and fears. Then they do something utterly surprising and you realize that you never knew them at all, or at least not in the way you thought you did. Did they suddenly change? Or were you missing something about them all along? Sometimes ignorance stems from a limited perspective. You cannot see the world the way another does. Sometimes it is because you rely too much on the head for understanding, or conversely, rely too much on the heart.

Most people believe that they understand what makes criminal violence bad. They see what it does to victims. But they still may miss an important dimension of the harm. They miss that some of the worst harms of criminal violence are to the soul. I sensed this, I saw this, in that North Florida courtroom scene described at this chapter's beginning. I felt this powerfully when as a young man someone close 
to me told me that she had been raped. I can remember where I was, how I was called to the phone; I remember the words she spoke and their nearly paralyzing effect on me. I can remember the inadequacy of my words in response. I was not the victim, but because the person raped was someone that I was close to, I felt a little of its chill. The relational effects of violence go deep and spread far.

The evidence for the relational harms of wrongful violence is overwhelming. And yet it is persistently denied, ignored or minimized. There are many reasons for this resistance to truth, including our determination to see ourselves as self-created. But explanation is not justification. The first step to full justice for those hurt by violence must be to appreciate their hurt, which is to the soul as well as the body.

\section{Notes}

1 This is a phrase frequently used after homicide. See Jill Leovy, Ghettoside: A True Story of Murder in America (New York: Spiegel \& Graf, 2015), p. 34.

2 Jill Leovy, interviewed Jan. 26, 2015; "Ghettoside" Explores Why Murders are Invisible in Los Angeles, National Public Radio, Fresh Air.

3 See David T. Courtwright, Violent Land: Single Men and Social Disorder from the Frontier to the Inner City (Cambridge, MA: Harvard, 1996); Lawrence M. Friedman, Crime and Punishment in American History (New York: Basic Books, 1993), pp. 173-92; Richard Maxwell Brown, No Duty to Retreat: Violence and Values in American History and Society (New York: Oxford University Press, 1991); Edward L. Ayers, Vengeance \& Justice: Crime and Punishment in the $19^{\text {th }}$-Century American South (New York: Oxford University Press, 1984); John Mack Faragher, Eternity Street: Violence and Justice in Frontier Los Angeles (New York: Norton, 2016).

4 While some states such as California and New York have extensive regulations on sales and possession of certain firearms, accessories and ammunition, no US jurisdiction has a general requirement of gun registration as many other nations do.

5 See V. Felliti, et al., Relationships of Childhood Abuse and Household Function to Many of the Leading Causes of Death in Adults: The Adverse Childhood Experiences (ACE) Study, 14 Am. J. Prevent. Med. 245-58 (1998). For more on the ACEs study, see the Center for Disease Control website, cdc.gov/violenceprevention/acestudy/a bout.html.

6 On "homicide eyes" see Leovy (2015), p. 34.

7 Tony Perry, Girls' killer gets life term, Los Angeles Times, May 15, 2010.

8 Jessica's victim impact statement, Herald Sun (Melbourne Australia) January 17, 2008, found at www.heraldsun.com.au/news/victoria/jessicas-victim-impact-statement/story (hereinafter Jessica's impact statement).

9 Serge F. Kovaleski, Killers' Families Left to Confront Fear and Shame, The New York Times, Feb. 5, 2013.

10 Alice Sebold, Lucky (New York: Back Bay, 2002), p. 113.

11 Sebold (2002), pp. 200-01.

12 Sebold (2002), p. 99. 
13 Found at http: //www.pwc-sii.com/CourtDocs/Transcripts/Sentencing=Mar16Motions. htm.

14 Kenneth C. Crowe II, Killer Faces Victim's Family, Albany Times-Union, August 27, 2013.

15 Maria L. La Ganga, Victims vent their anger as Garridos sentenced, Los Angeles Times, June 3, 2011.

16 David Abel, First responders still in grip of Marathon's horror, The Boston Globe, October 15, 2013.

17 Letter submitted at sentencing by the Adenhart family, quoted in Larry Wellborn, Driver Gets 51 Years to Life for Adenhart Death, The Orange County Register, December 22, 2010.

18 Francis V. Adams, In Practice: A patient confides her tragic secret, Los Angeles Times, August 2, 2010.

19 Franz Kafka, Metamorphosis and Other Stories (trans. Willa and Edwin Muir 1995). For a wonderful reversal of the story, in which a cockroach turns into a human being, see Haruki Murakami, Samsa in Love, The New Yorker, October 28, 2013.

20 Sylvia Hauser, "That Man Stole Me From Me"-A Story of Rape and Rebuilding, Knight-Ridder Newspapers, found at http://community.seattletimes.nwsource.com/a rchive $/$ ?date $=19910611$ \&slug $=1288360$.

21 Jessica's victim impact statement, Herald Sun, Jan. 16, 2008, found at https://www. heraldsun.com.au/news/victoria/jessicas-victim-impact-statement/news-story/ c68b5837eb0d14e27ab2af0d7c9571d3?sv=e3f3664e38b35672c0a6f466a573cda3.

22 Nearly There, posted by Lizzie 31_7 at 10:48pm, February 1, 2011, found at arapesurvi vorsblog.blogspot.com.

23 Jaimi Calfee's victim impact statement, Lincoln Journal Star, January 24, 2012, found at journal star.com/jamie-calfee-s-victim-impact-statement/article.

24 Amanda Lindout, with Sara Corbett, 460 Days, The New York Times Magazine, Sept. $1,2013$.

25 Id. at 26.

26 Mike Anton, Driver who killed pitcher is sentenced, Los Angeles Times, December 23, 2010.

27 Jessica's victim impact statement (see above).

28 David Zucchino, Catholic official found guilty in child sex-abuse cover-up, Los Angeles Times, June 23, 2012. The girl had gone to the priest for counseling because she had recently been raped by a family friend and did not have anyone else to talk to.

29 Jamie Kalvin, Working with Available Light: A Family's World After Violence (New York: Norton, 1999), p. 256.

30 "[M] $[\mathrm{Mrdering}$ someone's soul means depriving the victim of the ability to feel joy and love as a separate person." Leonard Shengold, Soul Murder: The Effects of Child Abuse and Deprivation (New York: Ballantine, 1989), p. 2.

31 In his novel about F. Scott Fitzgerald, novelist Stewart O'Nan has Zelda Fitzgerald write this about her husband after his death: "The soul aspires to be known." West of Sunset (New York: Penguin, 2015), p. 289.

32 Viktor E. Frankl, Man's Search for Meaning (Boston: Beacon, 2006); The Doctor and the Soul: From Psychotherapy to Logotherapy, trans. by Richard and Clara Watson (New 
York: Vintage, 1986). Robert Nozick, Philosophical Investigations (Cambridge, MA: Harvard, 1981).

33 For some people, the soul's primary connections may not be to other human beings, but to God, to the land, to plants or animals, providing examples of a need to belong that does not depend directly on human society.

34 Although it's true that part of the dramatic development in such crime narratives often comes from the protagonist's growing emotional attachment to another person.

35 Our understanding of the significance of relationships in identity, both individual and social, has been a hallmark of much work in psychology over the last generation. For an introduction to the field, see Christina Robb, This Changes Everything: The Relational Revolution in Psychology (New York: Farrar, Straus \& Giroux, 2006).

36 Young children sometimes make this clear. I can remember a picture drawn by my three-year-old daughter in which she colored herself and her preschool teacher with the same color brown, making them both appear to be African American. Although their skin tones were in fact close, an older person, based on many other cues, would clearly identify my daughter as white and the teacher as African-American. 


\section{2}

\section{BLAME FOR MORAL DISREGARD}

I once had to swim for my life in a rain-swollen river in Bolivia. Near the end of a long day our boat had overturned in rapids, four hours from the nearest town. I made it safe to shore or I would not be writing this; I mention the experience because of something I realized after hauling myself up on the muddy river bank.

As I caught my breath, I felt how alone I was. Everyone else on the boat, including my wife and older daughter, had been swept downstream. I did not know then what had happened to them. ${ }^{1}$ I was deep in an Amazon basin rain forest without any means of communication, with nothing but wet clothes, a poncho and a ruined camera.

My sense of aloneness, of vulnerability went beyond my physical situation, though. I was beyond the reach of right and wrong, good and bad. What had happened was awful, indeed might be much worse than I imagined, but the river did not care. The rain forest did not care. There at the river's edge, there was no one I could call, no one to complain to, no one to appeal to as the day's light began to fade. Because I was alone in nature and nature does not do responsibility.

In the developed world we are so used to living within systems of responsibility - systems of blame, praise and accountability - that we come to see responsibility as inherent in life, as basic as night and day or air and water. I think that was why, watching the heaving, roiling brown river sweep by without cease, I felt that a terrible mistake had been made. It felt as if some weird cosmic glitch had occurred and someone else's life had been switched with mine. This was not right. I had not signed up for this. I had done nothing to deserve it. It needed to be fixed, ASAP. Right now! 
But this was crazy thinking and unhelpful. I was assuming the possibility of responsibility. (As in: This is not right. I've done nothing wrong. Fix it!) But nature does not do responsibility. Only humans do responsibility.

Of all of the extraordinary creations that may be laid to human hands, from the wheel to language, to powered flight, computers, the Internet, and the hot shower (a personal favorite) perhaps the greatest and the least recognized is responsibility. Responsibility judgments are how we make human values real. By attaching consequences to human actions according to values like beauty, love, and justice, we give these values concrete form. Responsibility allows us to go beyond basic bonds of loyalty to family or tribe to valuing courtesy, friendship, law, and science. Without responsibility, we are just another species, fighting to survive.

The natural world abides by the laws of the physical universe, discoverable by scientific observation and testing. Here evolution and entropy and gravity rule. Nature does not recognize right and wrong, however. Rules of right and wrong are human creations. Judgments about blame and punishment depend on principles of our choosing. To put this another way, we are responsible for responsibility. ${ }^{2}$

In the previous chapter I detailed the harms suffered by victims of violence. In this chapter I turn to the other main party to criminal violence: the wrongdoer. I consider the moral and legal responsibility of wrongdoers: how they deserve our blame. Once again it may seem that I belabor the obvious. For example I detail the criminal responsibility of child sexual abusers, which is hardly a matter of major controversy. But understanding where we agree on blame will help us in situations where we disagree.

The drive to hold individuals responsible for wrongdoing-meaning to blame them personally-is powerful in American public life. If anything goes wrong in America we immediately ask who should be blamed (held responsible) for it. Our love affair with individual blame is very much part of our love affair with individual freedom. You get the freedom to choose what to do, but if you choose badly, you will be held accountable. Our enthusiasm for blaming individuals explains many distinctive features of American criminal justice, including its punitiveness. So understanding blame is very important to understanding justice in America.

In this chapter I consider how we construct moral and legal responsibility for wrongful violence in America. What are the basic principles that guide our blaming practices, both informal and formal?

My inquiry begins with popular culture. In movies and other popular entertainment we encounter the most intentional wrongdoing imaginable, committed by persons with the worst characters imaginable. The intentionality of the evildoer makes the heroic efforts of the protagonist to bring him or her to justice morally 
and emotionally satisfying. Real-life evildoing and responsibility look rather different, however. In criminal law, where we find arguably our most important blaming practices, violent actors are convicted and punished not just for fully intentional wrongdoing, but also for acts that demonstrate basic indifference to the good of another. Using the example of child sexual abuse, I describe how we assign responsibility for what I call moral disregard. Recognizing that we are connected relationally, we have an affirmative obligation to look out for the basic good of others to avoid harming them by our actions. This principle provides the moral foundation for all that follows in this book.

\section{Moral Responsibility for Criminal Violence}

Normally when we talk about violent wrongs we talk about public safety and the criminal law. We do not talk about morality, at least explicitly. Talk about morality in public discussions tends to be reserved for issues of sex and religion; controversies about abortion and contraception, gay marriage and transgender rights come to mind. For many progressives, this makes morality seem like a private matter, to be avoided in public discussions. It makes moral issues appear controversial and divisive. But moral questions run throughout most important public policy discussions, whether explicitly labeled that way or not.

For some, racial bigotry is a moral issue, a matter of basic right and wrong. Others emphasize morality in discussions of abortion. For some Americans, gun ownership is a moral issue; for others it is access to health care. Where we find strongly held personal views about public policy, we often find commitments to principles of right and wrong and responsibility. Which means a commitment to moral responsibility.

This is a book about justice, which means it concerns right and wrong, which means it concerns morals as well as law. To be just, criminal law must have a moral basis. Our great disputes about criminal law often involve basic questions about right and wrong. See disputes about consent in sexual assault, the parameters of self-defense or the justification for the death penalty. Blaming persons for violent wrongs also has a moral foundation.

\section{Learning about Blame from Liars}

We can learn a lot about moral responsibility from people who reject it. Consider persistent liars: people who believe there is nothing wrong with telling a few (or many) falsehoods for their own advantage. We blame them for lying, and yet they so often get away with it. What's going on here? 
Although most everyone lies at some point in their lives, most of us try to avoid it. Lying is wrong. Our moral sense decries it. Doing it feels bad. And yet in public and private life we encounter some people who seem to enjoy lying, or at least don't mind deceiving others when it may be useful. They take no personal, meaning no moral, responsibility for lying. They say to themselves, who cares?

The law sets some limits on lying. Under certain legally defined circumstances, lying will violate the law. Lying on the witness stand, lying to a federal agent, lying in an important financial transaction, these may lead to a criminal conviction or civil (money damages) liability. But there are plenty of times when the only penalty for deliberate deceit is moral. Personal or social disapproval, expressed in words and social sanctions, may result, but nothing more. And in a diverse, mass society where social connections are ever-more attenuated, social sanctions have less bite than in previous times.

If you lie about your past military service, for example, you may suffer no legal consequence. ${ }^{3}$ Many will think very badly of you, but absent unusual circumstances, the law will not intervene. Similarly, in sexual or romantic relationships, you can lie about past relationships, and many people do. Again, revelation of wrong will only bring moral, which is to say, social penalties.

We would like to think that perennial liars and other morally irresponsible people suffer for their bad choices. We trust that, they will get theirs. And I believe they do pay a major penalty in their chance at a truly good life. You cannot have the strong, nurturing personal relationships needed for a good life without holding yourself morally accountable. But let's not fool ourselves. While some morally irresponsible people end up in jail or otherwise disgraced, an ignominious end is far from inevitable. Serial liars and other morally irresponsible folks regularly get ahead. Way ahead. They earn large sums of money, get married, have kids, and garner social respect. Some become celebrities or win high public office. Even both. In their personal and professional lives, they may leave a long trail of the fooled and betrayed behind them, but they don't seem to mind.

The example of persistent liars illustrates some important features of our experience of moral responsibility.

Notice the feeling of blame. Notice how in blaming serial liars we feel it in our chest and gut, in our muscles and tendons. These feelings are especially strong when the blameworthy seem to escape liability. Irresponsible conduct that has no negative consequence can aggravate physically.

In blaming serial liars, we blame them for how they relate to others. In lying, they show disrespect for others. They do not care enough for those they trick to tell them 
the truth. They do not care about the pain that their lies will cause. In these ways, we blame liars for an attitude of disrespect for truth and person.

It is only because we are committed to granting individuals the maximum amount of personal freedom in America that we allow as much space as we do for immoral, including deceitful, conduct. We blame liars socially, but we want to save legal blame for conduct that causes direct physical, financial or institutional harms. When immoral conduct does seriously hurt others, we move quickly to the law, either civil or criminal. Then we blame, legally.

In a moment we will turn to criminal law to see how it handles blame. We will see that the criminal law sets out blame principles in doctrinal detail. It's a natural place to go to understand basic principles of individual responsibility.

But first we go to the movies, because here we see how blame works in our imaginations. Here we find narratives of good and evil and responsibility that entertain millions. We find a shared dreamscape that reveals basic hopes and fears and ideals about right and wrong doing. And so I ask, when we dream about holding wrongdoers accountable, what do we dream?

\section{Popular Blame, Part I: Evil in the Action Picture}

Action pictures are all about vanquishing evildoers. Good takes on evil-and prevails.

Hollywood's conception of evil usually features a deeply malevolent individual who is fully aware of the wrong he or she does. Think of Anthony Hopkins as the cannibalistic serial killer Hannibal Lecter in Silence of the Lambs, or Heath Ledger as the mass-murderous Joker in The Dark Knight. Here and in many other fictional examples, we encounter an evil genius whose commitment to wrongdoing is complete. He (only very occasionally she) is not only aware of, but delights in the wrong done. He consciously bathes himself in immorality. Such characters make for compelling drama - their badness does a great job of driving the action forward-but they bear about the same relationship to real human evil as the poltergeists of horror pictures or the alien predators of science fiction do to real-world hazards.

In our entertainment we prefer evil to be other: the devil, an alien species, a monster or malevolent machine. Even when the villain takes human form we indulge in what may be called the myth of total malevolence, that our enemies are 100 percent bad and 100 percent morally aware. Against such enemies we can unite in total opposition. There is no need for nuance, no call for empathic understanding. These figures are purely and simply, the Enemy. The Enemy fully realizes the harm it does, and fully embraces evil, making our opposition morally simple. 
Cinematic evil provokes powerful feelings of blame. Oh, something must be done about this. He is truly evil. Evil here is frightening and horrible, making the hero's retaliatory violence reassuring, exciting, satisfying. In this world at least, justice will be done. Evil will be found accountable. More often than not, movie justice means the painful, dramatic death of the evildoer at the hands of the hero.

In movie dramas, the wrongdoer is almost never condemned for a single wrong deed or even two. Instead we see a whole course of conduct demonstrating malevolence to others. He or she consistently shows aggression, hostility and disdain toward others. We may not see this at first, being fooled by the bad guy's skillful disguises and dissembling, but soon the truth is revealed. The central wrongdoer has a bad character. What a surprise- he's the bad guy.

Finally, from action movies we see that the emotional experience of heroes and villains can be important to blame. The courage of heroes contrasts with the cowardice (sometimes) of villains. Even more central to blame is the way that the main actors' emotions signal moral concern, or lack of it. The hero will be moved by compassion for the vulnerable; he will risk himself to protect them. The wrongdoer, meanwhile, will be impervious to others' suffering. In his violence, the villain may be hot-blooded or cold-blooded, but in either case he lacks the feeling needed to do right. He lacks the basic empathic concern of a person with conscience.

\section{Popular Blame, Part II: Real-Life Evil}

Real-life evil is much scarier than Hollywood evil because it is human, committed by persons capable of both good and evil. Real-life wrongdoers are not moral caricatures, devoted solely to wrongdoing. Nor do they display the same emotional appreciation of the wrong they do that we standardly see in fictional villains. Those who commit the worst acts of criminal violence almost always display a very limited appreciation of what violence does to victims. Just as they often do not appreciate the bad consequences of their acts for themselves, they rarely comprehend the full harm that they do to others.

It is true that some offenders take malevolent pleasure in the suffering of their victims. Yet if we look closely, we usually find that the perpetrator's appreciation for the human consequences of violence is superficial, because the actor's view of the victim is superficial. The victim is an obstacle, an annoyance, an opportunity, a target, an object of the actor's personal fears, anger or desire, but not a unique person who matters.

Real-life violence often happens swiftly, the decision to act taken in a moment of rage or upset, with little strategic calculation or consideration of consequences. The perpetrator does not think about what comes next. But the moral deficits of 
perpetrators appear not just in the moment of action. Even long after the violence, many wrongdoers do not appreciate how much harm they have done. They don't really get it.

Listen to the voices of offenders, explaining their acts of violence, how they justify them to themselves. A teenager who severely assaulted another student at high school:

People may have thought I went too far on that dude, but I later knew what I did was right. It must've been right because nobody was giving me any shit any more ... I was ready to throw down with everything I had. If a motherfucker loses his teeth, then he lost some teeth. If he loses his eye, then he lost an eye, and if he loses his life, then he lost a life. It didn't matter to me. The way I looked at it was that it is just one less motherfucker in this world [that I] will have to put up with. ${ }^{4}$

Perry Smith on killing all four members of a Kansas farm family, the Clutters, with his crime partner Dick Hickock, as part of a robbery:

Am I sorry? If that's what you mean, man-I'm not. I don't feel anything about it. I wish I did. But nothing about it bothers me a bit. Half an hour after it happened, Dick was making jokes and I was laughing at them. It's easy to kill—a lot easier than passing a bad check. Just remember: I only knew the Clutters for maybe an hour. If I'd really known them, I guess I'd feel different. I don't think I could live with myself. But the way it was, it was like picking off targets in a shooting gallery. ${ }^{5}$

A teen gang member:

When I get really angry it's like I don't care about nobody. I just want to get my anger out. Fight somebody, do something to get it off my mind. ${ }^{6}$

In all these voices we hear a narrow, self-absorbed explanation of conduct. They express a me-first philosophy. It's all about the perpetrator's feelings and needs and very little about the person hurt. There is little emotional understanding of the harm, or wrong, done. Certainly there is no comprehension of the soul harm of violence.

In crimes of sexual violence, we see the same failure to appreciate the harm done to another. Sex offenders tend to see their victims as projections of their own personal needs and expectations. The following are from convicted rapists. 
A man's body is like a coke bottle, shake it up, put your thumb over the opening and feel the tension. When you take a woman out, woo her, then she says no, I'm a nice girl, you have to use force. All men do this. She said "no" but it was a societal no, she wanted to be coaxed. All women say "no" when they mean, "yes" but it's a societal "no," so they won't have to feel responsible later.

At the time I didn't think it was rape. I just asked her nicely and she didn't resist. I never considered prison. I just felt like I had met a friend. It took about five years of reading and going to school to change my mind about whether it was rape. I became familiar with the subtlety of violence. But at the time, I believed that as long as I didn't hurt anyone it wasn't wrong. At the time, I didn't think I would go to prison. I thought I would beat it. ${ }^{8}$

The following is from a man convicted of abducting an underage girl at knife point, taking her to a motel and raping her. He saw his only mistake as using a knife to threaten his victim. Without the knife, it would not have been rape, he believed, even though he still would have compelled her to have sex.

After I paid for a motel, she would have to have sex but I wouldn't use a weapon. I would have explained [that] I spent money and, if she still said no, I would have forced her. If it had happened that way, it would have been rape to some people but not to my way of thinking. I've done that kind of thing before. I'm guilty of sex and contributing to the delinquency of a minor, but not rape. ${ }^{9}$

A young man who raped his victims at gun point and then killed them:

Physically they enjoyed the sex [rape]. Once they got involved, it would be difficult to resist. I was always gentle and kind until I started to kill them. And the killing was always sudden, so they wouldn't know it was coming. ${ }^{10}$

These accounts of evildoing reveal a kind of moral stupidity. Offenders may have a basic mental understanding of what they do but no real emotional grasp of what it entails for victims. Instead of malevolently seeking-emotionally reveling in-a victim's hurt, many real-life perpetrators display disinterest in the victim's experience. They demonstrate a so what? attitude. As in, what's that to me?

While real-life offenders do not demonstrate the full commitment to evil that cinematic villains do, we have no problem holding them responsible. As we will see, by their choices to act in harmful ways, they easily meet the blame requirements of criminal law. We also blame them morally. We do so robustly, confidently, passionately. 
But we need to be clear about why we blame here. We need to make sure that we are not fooling ourselves about wrongdoer responsibility. If real-life wrongdoers lack full emotional appreciation - full understanding - of the wrong they do, and there's plenty of evidence of this (see above), then our blame should not assume they have such understanding. Our blame must rest on a different foundation. I will argue that in most cases, we blame real-life offenders for harmful actions that show disregard for their victims. That's why we blame.

\section{Blame in Criminal Law: Child Sexual Abuse}

The word criminal connotes moral as well as legal blame. Public discourse about crime makes this clear. Criminals are described not only as dangerous but as (morally) depraved. They deserve punishment because they have chosen to act wrongly. They should be blamed. This means that we should be able to learn about moral responsibility by looking at blame in the criminal law. Especially we should be able to learn from crimes of violence, which virtually everyone condemns.

Like other teachers of criminal law, I rely heavily on homicide offenses to teach students about how the criminal law assigns individual responsibility. The various forms of murder and manslaughter present a richly varied set of offenses based on different kinds of criminal intent. Homicide is our most serious offense, and it is certainly familiar to students from print media, television and movies.

But I am not going to use homicide to teach here. I choose a more uncomfortable wrong. As our exemplary offense I choose the crime of child sexual abuse as committed by an adult. (Although the crime can be committed by persons under the age of 18 , I will focus on offenses by adults because adults are generally seen as the most blameworthy offenders.)

I choose child sexual abuse in part because of the modern consensus about its heinousness. If we can agree on the blameworthiness of adults who sexually abuse children (surely we can, yes?), then the offense may help us understand blame in other contexts. I also choose this offense because it illustrates that we are actually quite comfortable blaming wrongdoers without proof of the kind of evil aim and understanding characteristic of fictional villains.

\section{The Soul Harm of Child Abuse}

As we saw in Chapter 1, understanding criminal violence begins with the harm done to victims. In child sexual abuse, it begins with the child's pain. This pain may be physical; it is almost always emotional. The child will be confused and feel 
alone. These are but symptoms, though, of the harm done to the child's soul. The hurt comes from the child's premature introduction to intimate human connection by an adult the child cannot refuse.

A child, by definition a vulnerable being who is still learning the most basic relational skills and patterns, is thrust into the most adult form of interaction, one that he or she cannot manage. The move to the sexual exacerbates the power imbalance between adult and child. The adult here is totally in control and directs interactions to satisfy his or her needs without regard for the child's good.

By making the relationship sexual, the perpetrator steals an important part of childhood, making it impossible for the child to be fully a child thereafter. The act disrupts life patterns and relationships. It disrupts relationships with present family and friends and with potential friends and intimates. The offender changes the child's sense of self and place in the world. Who am I now? the child will ask, and not receive any satisfactory answer because his or her situation will seem unprecedented. (Though unfortunately it is not.)

Untreated, the harm of child abuse can grow along with the child. It may lead to difficulty trusting others, which makes entering into close, mutual relationships almost impossible. Childhood trauma, including child sexual abuse, is strongly associated with mental illness, especially depression and forms of dissociation. It can inspire a wide variety of risky behaviors and substance abuse. The harm to present and future life can be enormous.

Although not fully understood in previous times, the soul harms of child abuse are well known today. Learning about them represents a signal advance in human understanding. On the terrible harm and the great wrong of child sexual abuse, I trust we can agree.

\section{Blame for Child Sexual Abuse: Legal Requirements}

As with almost all serious crimes, a defendant cannot be convicted of child sexual abuse unless he or she acted with the criminal intent required for the offense. Criminal intent, also called mens rea, distinguishes a criminal act from an innocent one, a criminal wrong from a civil wrong, or between different kinds or degrees of offense. The usual rule of criminal law is that some form of mens rea, also known (often misleadingly) as criminal intent, applies to the essential wrong of the crime.

To illustrate, in premeditated murder, the defendant must have acted with the purpose to kill and have premeditated the killing. He must have calmly considered the homicide before killing. Killing is the essential wrong; the required forms of criminal intent are premeditation and purpose to kill. Criminal blame tracks the defendant's aims and decisionmaking with respect to killing. 
In child sexual abuse, the essential harm of the offense is interference with a child's body and soul by coerced sexual activity. Yet the criminal intent required goes only to the sexual nature of the defendant's action. No proof of intent-no purpose or state of awareness - is required as to the age of the child, the harm done the child, or the use of physical force or other coercion.

In most jurisdictions, the prosecution must prove that the prohibited act (genital touching, penetration or other specified conduct) was done with a sexual purpose. A touching of a child's private parts that is accidental or done for a medical purpose, for example, would not be criminal.

The prosecution must also prove the victim's young age. Offenses may be distinguished by degrees of youth-under 18 , under 16 , under 14 , for example. But there is no requirement that the defendant know the victim's actual age. The age element is what is called strict liability. This means that no proof is required that the perpetrator knew or even reasonably should have known the victim's age. In most cases, of course, the perpetrator is well aware of the victim's age, and if not, certainly should have been. The victim is clearly a young person. Legislators and courts nevertheless do not require proof of awareness of age, largely for pragmatic reasons. They fear that requiring intent as to age would make successful prosecutions more difficult by allowing defendants to claim age-ignorance. This would leave children more vulnerable to adult abusers.

Nor does this crime require proof of victim nonconsent. In law, a child cannot consent to sexual conduct. This means that a perpetrator's belief that the child wanted to have sexual contact is irrelevant.

Nor is there any requirement that the defendant had a purpose to harm the child or was aware of the harm that likely would result from his or her conduct. A perpetrator might (and we will see this is true in some cases) believe that the interaction with the child is positive, or at worst involves only trivial harm-and still be guilty of the offense. A perpetrator might believe (and again this happens) that he or she and the child have a truly loving relationship and still be guilty of-be blamed for-the offense.

By not requiring proof of awareness as to age, nonconsent or harm done, the criminal law presumes that the defendant deserves blame because he or she chose to engage in sexual interaction with a child. The law presumes that the physical appearance of the child — his or her evident youth — will alert any adult to the harm and wrong of sexual interaction.

I doubt that many readers will be offended by the law's limited view of criminal intent here. Convicted child sexual abusers know more than enough about what they do to understand its wrongness. If they had cared about the child, as a child, they would have understood the wrong. Instead, their chosen, harmful acts 
demonstrate a disregard for the child's basic human value, violating basic community principles for how children should be treated. Their conduct should be punished.

Notice that in blaming here we link what offenders saw and understood with what they could have and should have seen and understood. We blame them for wrongs bigger than they actually comprehended. This gap between our blame and their understanding will seem even larger when we look at the psychology of child sexual abusers.

\section{The Perpetrator's Perspective}

Some perpetrators of child sexual abuse - fortunately a small minority-do not see anything wrong with consensual (as they see it) sexual interaction with children. ${ }^{11}$ By contrast, perpetrators recognize the wrongness of child sexual abuse generally. But that does not mean they comprehend their own wrongdoing. Assuming they admit to sexual contact with a child, they may contend that in this case, it was not that bad. The point is that a surprising number of child abusers do not appreciate, fully or at all, the wrong they did.

Many male perpetrators believe that a man's sexual needs are fundamental, persistent and undeniable. They require regular satisfaction. This, in their minds, reduces their personal responsibility for sexual conduct that occurs when their needs have been denied by other adults. Thus child sexual abuse may occur when a regular partner such as a wife or girlfriend is not available and the man looks for other sexual partners, even in the same household.

Perpetrators often have a sexualized view of the child victim. In recounting the incident, abusers describe the victim primarily in sexual terms. They see the child acting with a sexual interest consistent with their own. In effect the victim becomes the reflection of the perpetrator's sexual desire. Reality shifts-not entirely, but in significant part- to accommodate the perpetrator's goal of sexual satisfaction.

Douglas W. Pryor, writing of male child sex abusers, describes a process of depersonalization during the abuse incident, in which the man suspends empathetic understanding of the child.

However the younger person might have reacted to what was happening, the man either ignored or redefined the reality of the other party during the immediate context of offending. Victims were almost always seen as enjoying the experience, as willing participants, as old enough to make up their own minds about sex regardless of their age, as having not offered enough resistance. At the same time, offenders admitted that they virtually never ask their 
victims whether they wanted to have sex, that their victims were often silent or outright resistive, and that signs of distress were continually visible around them. ${ }^{12}$

Child abusers frequently describe their victim as willing, even seductive. They describe a sexual actor who bears almost no resemblance to a child. ${ }^{13}$

\section{Blaming Abusers for Moral Disregard}

In child sexual abuse, the child suffers unjustified pain because of the offender's sexual acts. In terms of long-term damage, it is one of the worst crimes imaginable. We condemn it completely. But why do we feel so confident blaming perpetrators who may not have fully understood the harm and wrong they did?

The simple answer is that we blame perpetrators for not getting it. We condemn conduct that, in cognitive terms may have been more stupid (not getting it) than vicious (wanting to hurt) but that does not change our view of their responsibility. This is because, in practice, we do not require full awareness of wrong to fully blame.

To use a driving analogy, we generally believe that a person who deserves serious blame saw the red light, but chose to ignore it. She heard morality's warning bells but decided to proceed regardless. When the crash occurs, we blame her for her conscious choice to disregard the warnings. We say that she fully and freely chose to do wrong. At least in some cases, though, this appears a convenient reconstruction on our part to make us feel better about blaming them. It is truer to human reality - to what wrongdoers actually understand-to say that we blame offenders for harms they would have seen if they had paid even basic attention to those hurt. We blame them for an attitude of disregard.

Child sexual abusers demonstrate the twin features of what I call moral disregard. First, they do not see their victims as they are. They do not see them as children who, because of their youth, are terribly vulnerable to sexual abuse. Second, abusers do not care for the basic good of the child. No one who cared for the child's actual good would act this way. As a result of their disregard, abusers do not actually appreciate the long-lasting human harm-the soul harm-that they do. Their failure to understand is still culpable - we can blame them for it-because in their actions, they put their own needs and desires ahead of the most basic needs of their victims.

Like every other kind of understanding, moral understanding requires interest and effort. We must try to understand. In the same way that you can ignore words on the page, or voices in the street, you can ignore signs that someone may be 
seriously hurt by your actions. Focused on your own needs, consumed with your own perspective on persons and events, you can miss the wrongness of your conduct. If you are not morally interested in other people, meaning if you do not attend to their basic welfare, then you may very well miss the lights, sirens and bells warning of serious wrongdoing. As a result, you may have a very superficial understanding of the harms and wrongs you do.

Blaming abusers for their disregard is a form of individual responsibility. But it is also very much a social judgment. The social aspect of criminal blame is easily missed when, as here, our feelings about blame are intense. Of course an adult who has sex with a child should be held criminally responsible. How could he not? And yet criminal blame for child sexual abuse here is a relatively recent development in the West and is not universally accepted elsewhere.

The common law of England, which applied in many American jurisdictions through much of the 19th century, set the age of sexual consent at between 10 and 12 years old. This meant that a child as young as 10 in some jurisdictions could legally consent to all sexual acts. This was at a time when girls reached puberty much later than today, often not until 14,15 or 16 years of age. ${ }^{14}$ Today, a number of cultures and legal regimes around the world permit adult-child sexual interaction through child marriage. ${ }^{15}$ Rules about lawfulness are never just about the choices of individual actors; they are always, also, about our own. The rules are ours.

\section{Objections to Blame for Moral Disregard}

I anticipate at least three basic objections to blaming persons for harmful actions that demonstrate disregard. First, some may say that this entails blaming for bad character, which should never be the basis for criminal liability. Second, some may say that blaming for disregard is essentially blaming for not caring about others, which should not be allowed if the person is incapable of such feeling. Third, some will argue that basic precepts of American freedom preclude requiring anyone to care about (have regard for) a stranger. I will take up each in turn.

\section{Blaming for Character, not Conduct?}

One of the biggest differences between blame in and out of the criminal courtroom is the need for courtroom blame to be based on conduct, not character. A person should be found guilty based on facts proven about his or her actions, not on reputation for good or bad behavior. By contrast, outside the courtroom, assessment of a person's character often has a major effect on responsibility decisions. 
Imagine that someone in your circle of acquaintance is accused of wrongdoing. There is an accusation of lying, stealing, or sexual harassment. You are asked for your opinion. What do you think happened? Who should be blamed? Is anyone to blame?

To answer these and related questions, you would like to know the facts about who did what, when and where. This will help determine why the people involved acted as they did, which should help in judging responsibility. But reliable information about controversial events can be hard to obtain. Memories are imperfect and may be colored by self-interest. Witnesses or participants may refuse to tell what they know. And even if we have all the facts, there may still be serious questions about $w h y$ persons acted as they did, questions that can be vital to blame determinations.

Faced with these difficulties, we often look to character for help. What kind of person is this individual? What do we know about him or her outside of this incident that may shed light on their propensity to do right or wrong? In trying to decide whether the accountant stole from her employer or just made bookkeeping mistakes, we might ask: Does she seem like a person who would steal? What do we think about her honesty? Has she ever stolen before? In the case of alleged sexual harassment, we might ask, have I seen the accused be sexually aggressive before? Is the accuser in this case usually trustworthy? Insight into character may guide assessment of particular conduct.

Outside the courtroom, character blame is very popular and often very useful. We employ character assessment to decide who we want to be in relationship with and who we do not, who we can trust and who we cannot. It is a staple of our entertainment culture. We often talk about who is "basically a good guy" and who is "a total jerk." These are character judgments. We will see that character blame is generally popular with police officers. For many, gut feelings about moral character are central to judging the responsibility of others.

But character blame is too unreliable for criminal verdicts. Judgments about character may just express personal likes and dislikes; they may be emotional responses to perceptions of who seems like us and who seems different. Unless we are very careful, character blame inspires a form of good guys versus bad guys oversimplification that can produce serious mistakes in judgment. I will show how this happens, in some detail, in Chapter 3. Indeed, the hazards of character blame will be a cautionary theme throughout the rest of the book. As a result, it would be a serious mark against blame for moral disregard if it proved to be a form of character blame. But it is not.

In criminal law we generally blame for illegal acts done for bad reasons, what the law calls mens rea. Mens rea may turn on the person's immediate purpose in acting 
(to kill or to steal, for example) or on the actor's state of awareness (of the illegal drugs in the car, for example) or, on occasion, what he or she should have been aware of (such as a partner's lack of consent to sex, for example). The focus is on the actor's cognitive state of mind at the time. Blaming for disregard, meanwhile, rests on proof of a culpable attitude toward-not caring about - another person or persons. This might seem to be a character judgment because it seems like saying the person had a disposition to callousness or cruelty. But the assessment is still based on particular conduct. We look to acts of violence that demonstrate disregard, as we did before with child sexual abuse.

Blame for disregard recognizes that our choices depend not just on cognitive states of mind but also on our attitudes and emotions. In its limitation to cognitive states, the law's mens rea approach to culpability is like photographing a scene in black and white. Most of the important visual information will be provided, but not all. Blaming for disregard adds color to the responsibility picture by including the actor's attitudes and emotions. But that does not make it a form of character blame.

\section{Problems in Moral Capacity}

In moral philosophy it is often said that should implies can. To say that the person should have done differently implies that the person could have done differently. Blame for failure requires that the individual had the capacity for success. It would be crazy to blame a 70-year-old for not being able to run up a flight of stairs the way a 20 -year-old might. Or to expect a person without any musical training to sing a melody in tune after hearing it just once. We know that certain capacities are strongly shaped by genetics. For example, I have limited mathematical abilities. I distinctly remember a high school math teacher's comment on my report card. He wrote simply: "Sam does the best he can." And that was true. If the results were modest, that was because of my modest mathematical ability.

Notice that these examples involve nonmoral capacities: physical, musical and mathematical. The question is whether we can also sensibly talk about moral capacities. A number of moral and legal philosophers say that we can and argue that deficits in moral capacity should limit a person's moral responsibility.

Proponents of the moral capacity approach say that the criminal law's insanity defense excuses from criminal responsibility because the insane lack the capacity to understand the difference between right and wrong. They argue that the very young (usually under seven) are excused from legal blame because of a lack of 
capacity for moral judgment. Perhaps. The people that really put this concept of moral incapacity question to the test, however, are psychopaths.

\section{Psychopathy}

Psychopaths are some of the scariest people in the world because most seem so normal. Many are quite charming and socially adept. Some are very successful in business and in social interactions. What makes them dangerous is that, for reasons we do not fully understand but that likely have a significant genetic component, psychopaths have strong tendencies to risk-taking, impulsivity and generally lack empathy for others. Some have theorized that genes for psychopathy have persisted in the human race because psychopathic traits can be critical to individual and group survival in certain times and places. The desire and ability to take enormous physical risks, for example, is very valuable in war. There are times when making leadership decisions without concern for the welfare of individuals may provide major benefits to the surviving group. ${ }^{16}$

Although the percentage of psychopaths in the population is low, probably no more than one or two percent, it is higher in certain groups. Some have speculated that psychopaths are overrepresented in the ranks of chief executive officers of large corporations, because of the ruthlessness that gaining and holding such positions often requires. Psychopathy is certainly overrepresented among those incarcerated in jail and prison. While many psychopaths do not display any violent or criminal tendencies, those who do are some of the most dangerous people we may encounter. Which brings us to the critical responsibility question. Remembering the adage that should implies can, how is it fair to blame psychopaths for moral disregard when they appear to lack the trait, empathy, that is critical for moral regard? How can persons who do not feel for others and seem to lack a conscience, be morally blameworthy for acting badly?

Now psychopaths are not the only ones who might claim diminished or no capacity for moral understanding. Many young men become violent because they see threats that others would not. They become extremely angry or fearful where others would not. As a result, their ability to assess situations properly and avoid violence is much reduced. Why are they so sensitive to threat? Often their sensitivity is hard-earned, a result of having witnessed or experienced violence as children. They may also live in a community where the ability to threaten or use violence is critical to social standing and personal safety. ${ }^{17}$

We know that trauma, poverty and race discrimination can powerfully affect personal development, including moral development. It is a commonplace that sex offenders often have personal histories of childhood neglect and mistreatment. 
Many have suffered sexual victimization leading to a distorted view of sexuality and an apparent inability to comprehend the harms of their own sexual violence.

For all these offenders we might ask, the same as with psychopaths: how is it fair to blame them for doing wrong without weighing on the judgment scale their deficits in moral understanding, which mostly stem from causes outside of their control? How is it fair to blame them if they lacked the ability to emotionally appreciate the harm they did at the time?

The answer depends on our conception of individual responsibility. It depends on what we see as the purpose of legal and moral responsibility. It is a question best answered by looking at particular cases. Consider individual responsibility in the following case.

On April 20, 1999, Eric Harris and Dylan Kleybold arrived at Columbine High School on a killing mission. Armed with two shotguns, a semiautomatic rifle, two semiautomatic handguns with large magazines, numerous homemade pipe bombs, and two large propane gas cylinder bombs, the two killed 13 and injured 21 others. They then killed themselves. But deadly as this toll was, it was far less than they had sought. If the two propane bombs in the high school cafeteria had gone off during lunch as planned, the explosions would have brought down the structure, killing hundreds. Then the two planned to shoot any survivors who fled the scene. They had set car bombs to kill those who managed to reach the apparent safety of the parking lot. ${ }^{18}$

Eric Harris was the leader of this homicidal endeavor. He kept a journal of his thoughts and plans, and a website. He wanted the world to know who he was and why he did what he did. A senior in high school, he was an angry young man who believed himself intellectually superior to most, perhaps all, around him. "I am GOD compared to some of these un-existable zombies." ${ }^{\prime \prime}$ On his website he declared war on all humankind, writing " $i$ don't care if I live or die in the shootout, all I want to do is kill and injure as many of you pricks as I can." ${ }^{, 20}$ Harris was an otherwise successful and popular student who appears to have been motivated by hatred or disdain for fellow human beings. He was an accomplished liar who deceived his parents, teachers, a probation officer and friends about his plans. He took great pleasure in his ability to deceive, seeing it as proof of his superiority.

Although Harris showed occasional signs of caring for other persons, he was likely a psychopath. He certainly had no empathy for his victims. He certainly would have scored high on the checklist used to measure psychopathy. And yet, had he survived, he almost certainly would have been convicted of multiple counts of premeditated murder. He still acted with a purpose to kill, and with premeditation of the killing. American law does not recognize a defense of psychopathy. 
But what about his moral as opposed to his legal responsibility? If he lacked significant capacity to comprehend the wrongness of his conduct due to psychopathy, if he lacked the emotional capacity to empathize with his victims and their families, does that mean that he cannot be morally blamed for what he did? If moral responsibility is about an individual's choices according to the person's emotional capacities, perhaps it does. Since empathy is key to recognizing the wrong of doing harm, some say that without it, the person cannot be morally blamed for wrongdoing.

But do we really feel that Harris is blameless, or even less blameworthy in his mass killing because of his moral and emotional deficits? I do not. It seems to me that his not-getting-it about the value of human life is exactly why we find his actions so egregious. It is what we blame him for. His considered attitude of disregard for fellow human beings calls for condemnation. By us. But notice, blame here does not depend on Harris fully understanding the wrong he did.

Once more we need to appreciate the social dimension of moral responsibility. In blaming Harris we do not undertake a God-like examination of his mind or soul, nor a psychological or neurological assessment of his mental and emotive capacities. Instead we hold him responsible for homicidal conduct that violated basic community norms.

Harris was a rational actor who killed for rational, albeit immoral reasons. Through mass killing, he sought fame and power. He completely disregarded the value of his victims. He deliberately flouted the basic moral code of the community. In seeking to hold him responsible, morally and legally, the community defends basic human value. That's what we do with both moral and criminal responsibility.

\section{Social Expectations and Individual Responsibility}

The example of psychopath responsibility reinforces the importance of relational identity, clarifies what we mean by fairness in blame, and underscores our own moral responsibilities as judges of others' wrongdoing.

We often underestimate the power of social expectations in blame because we underestimate how much our relations with others shape who we are. We know very well that positive expectations can shape individual behavior. Teachers know that, properly motivated and taught, students will rise to meet the teacher's expectations for learning. Coaches know that expecting more of players will raise their level of play. We also know that negative expectations can have negative effects, something we see in almost all failed social institutions, including schools. We live our lives in relation, affected by the expectations that others have for us. These do not determine our thoughts, feelings, or actions, but they have an effect. 
The significance of social expectations to the responsibility of psychopaths also helps clarify the kind of fairness that moral and legal blame requires. Instead of requiring equal capacities to do right, fairness in blaming depends on equality of expectations. We should ask: To what extent are all in society held to the same basic obligations of moral regard in their conduct? Fairness requires that all persons in a community, regardless of power, wealth, fame or other source of influence, meet the same requirements of regard. Fairness does not require that all persons be similarly situated with respect to moral capacity. To blame fairly requires something less, but still something grand: that all in the community be held to the same moral expectations.

Being subject to responsibility is vital to community membership. You cannot fully belong without it. History provides many examples. Race slavery in the United States depended on an ideology of white supremacy in which men and women of African descent were seen as lesser beings who could not be expected (read trusted) to live in free society. Slavery was, in part, a means of ordering beings who could not be expected to order themselves. The past treatment of women, the mentally ill and the disabled, follow similar patterns. Holding persons to basic standards of moral responsibility is a hallmark of basic human value.

Recognizing the importance of social expectations to individual responsibility should also remind us of the moral responsibilities of those who judge. They should remind us of our (the law-abiding's) responsibility for community values.

Basic community values seem timeless, and indeed we aspire to make them timeless, but looking back on history we see that some basic values change over time, bringing changes in moral and legal responsibility. Racist beliefs which were once normative in the United States have become socially unacceptable today. Sexist ideas that were once widely accepted are now subject to social, politicaland moral—condemnation. ${ }^{21}$ These value changes have wrought changes in social and legal responsibility.

Looking at the criminal law, we see dramatic changes in the law of rape reflecting changes in the value of women and their rights to sexual autonomy. In the recent past many jurisdictions required proof that a female victim physically resisted an assaulter in order for her to be raped. A woman paralyzed by fear could not be raped unless the assaulter used overwhelming force or threatened a deadly attack. A wife could not be raped by her husband because of the law's requirement that the victim be a woman "not the man's wife." Under earlier law, a defendant in a rape case could attack the victim's credibility by a broad attack on her chastity. The assumption was that a woman with sexual relationships outside of marriage was less trustworthy when she complained of sexual coercion. These rules reflected now- 
archaic views of women and their sexuality. In most jurisdictions, these rules have been changed because of changes in the position of women in society and respect for female sexual autonomy. ${ }^{22}$

We are responsible for responsibility. We could mitigate punishment for psychopaths, if we wish, or even excuse them from criminal responsibility entirely. We could take a different approach to child sex abuse than current criminal law does, if we wanted. We do not because these choices would contradict our vision of community. Therefore they contradict our sense of justice.

\section{Individual Freedom and Obligations of Moral Regard}

Now I take up a very different objection to moral regard involving an (apparently) very different group. Anticipating the justice work to come, we consider regard as it applies to judges of wrongdoing rather than to wrongdoers. If moral regard is to serve as the foundation for justice, it must apply to all. What about the moral regard obligations of the law-abiding? Why should citizens who have done nothing wrong have to care about the basic good of totally unrelated persons, especially if those persons have done wrong? Hell no. That's un-American.

Many Americans believe that individual freedom means not owing any moral obligations to strangers. The idea is that in America you don't have to care about anybody else as long as you don't violate the law. You don't have to care about the poor, or the rich for that matter. You don't have to care about people who drink themselves to death or smoke or consume way too much soda. It's their life. A citizen's only public obligation is to the law. Under this view, requiring moral concern for strangers-looking out for their good-smacks of the overweening approach of a totalitarian or theocratic state. ${ }^{23}$ I can easily imagine the objection that any requirement of seeing or caring about others (i.e., moral regard) infringes on personal freedom.

The freedom objection takes us back to the ideal of individual autonomy discussed in Chapter 1. You will recall that this was the notion that individuals are fundamentally autonomous. Individuals may choose to forge close personal connections: they may choose to care about each other. But this is purely a matter of individual choice. An attitude of indifference to the welfare of others is perfectly acceptable.

But as we saw in Chapter 1, who we are depends in part on our interactionsour relations-with others, including unchosen relations. In fact we have far more connections with others than we might like, which means we have more moral responsibilities than we might prefer. Living in a community means that the rich 
have connections with the poor, white with black and men with women. These are often complex, important-and unchosen relations.

Indifference toward those we are in relation with represents a view of their value, meaning that it is a moral stance, with moral consequences. Deciding to stand apart, to be "neutral" and disengaged, is to take a moral stance with potentially damaging effects on others. The history of individual freedom in America illustrates.

History teaches that without a commitment to moral regard, individual freedom is a value enjoyed by the haves at the expense of the have-nots. There may be no better illustration of this truth than race relations in the United States. Following the Civil War, the federal Constitution was fundamentally altered with the passage and ratification of three amendments. These new provisions sought to eliminate slavery (Thirteenth Amendment), grant equal civil rights to all citizens regardless of race (Fourteenth Amendment) and protect the right to vote from race discrimination (Fifteenth Amendment). Without a commitment to moral regard for African-Americans, however, these on-paper powerful rights soon succumbed to the bigotry of white America. A process of political, legal, economic and physical oppression of former slaves ensued in the South in the form of race terror (lynchings and the Klan) and legal segregation (Jim Crow laws). In the North and West, other forms of legal and customary discrimination kept blacks marginalized. White Americans everywhere vigorously defended their freedom to live and work apart from African Americans. A rhetoric of rights—states rights, rights of private association, and rights to neighborhood schools, and more-was invoked to support white freedom.

In the mid-20th century, the civil rights situation in the United States began to change. The federal courts saw the Reconstruction era constitutional amendments in a new light; new federal civil rights legislation was passed, and both public and private discriminatory practices came under attack. Much changed in law, economics and culture with regard to race. Critical to these public policy changes was a shift in dominant American culture on the value of darker skinned people. Only when whites - at least more whites-began to treat African Americans with a modicum of moral regard, only when African-Americans insisted on being treated with moral regard, did racial nondiscrimination become an accepted American norm. In this process of change, court decisions mattered. Legislative change mattered. Economic and political changes, both domestic and international, mattered. Nonviolent protest mattered. But without a shift in regard for African Americans, the oppressive legal and social structures of the racial past, defended by many as morally neutral (see the doctrine of separate but equal), would have remained in place. Regard matters. 


\section{Conclusion}

A question: in most situations do you lead with your head or with your heart? Myself, I have always been a head person. I approach situations analytically rather than intuitively. I am very good at seeing individuals, relationships and institutions from a distance, making analogies and creating hypotheses, considering rival perspectives and drawing logical conclusions. This has been a great help in legal practice and in legal academics. It doesn't work everywhere, though. In being a husband or father, or a minister, it's often a problem. Sometimes you want a Mr. Spock around. And sometimes you don't.

When I spent a summer working as a chaplain intern in a large hospital, I found that when I led with my heart I did fine. If I could enter a patient's room with a smile and brief introduction and not worry what came next, if I could trust myself to take cues from the patient, the pastoral visit would go (mostly) as it should. But this approach did not come naturally. My natural tendency was to think it all out, before, during and after. My natural inclination was to try to script my words ahead of time and then second- and third-guess everything I said or did. As you might guess this led to awkwardness, as I listened more to the analytical voice in my head than the patient I was meant to see.

Despite dealing with highly emotional events, or perhaps because it does, the criminal law mostly leads with the head. It seeks dispassionate analysis of what the accused did and why. Blaming for disregard, with its requirement of basic concern for victims, is more heart-oriented. In this it is closer to the human experience of being wronged, of doing wrong and of judging wrongdoers. We relate to each other emotionally as well as cognitively, using feelings as well as conscious thought in choice.

My experience as a chaplain has also taught me the need to try to see and hear others. There is so much static in our lives-there are so many voices and distractions in the world and in our heads - that it can be hard to see and hear the actual person in front of us. We may see the form and the type. We may respond to their words and actions, but to be fully with another, requires active attention; it takes moral interest. In this chapter we have seen that basic moral interest is also needed to avoid doing bad.

Looking ahead, moral regard will be an invaluable guide for just decision making. I have noted before how much we Americans love to blame. Especially in response to violent wrongs, this blame often comes out of the fire of our anger and fear. The strong emotions associated with blame make it easy to over-blame-to exaggerate wrongdoing or seek excessive punishment. A requirement of seeing the unique person of the wrongdoer and caring for his or her ultimate good will be important checks on the urge to blame too much. Moral regard will help us see that they are often not as bad as we imagine, and we are not as good. 


\section{Notes}

1 Everyone on the boat survived the episode, with only minor injuries. We were all reunited before night fell, and then spent the next sixteen hours on a sand bar before our eventual rescue. But that's all a story for another time and place.

2 I sidestep any consideration of natural law or religious foundations for moral and legal principle here; this is not because they are not worthy of discussion, but because of my stated desire to present a secular discussion of criminal justice that does not depend on any preconceived moral or theological base.

3 See, e.g., U.S. v. Alvarez, 567 U.S. 709 (2012).

4 Quoted in Richard Rhodes, Why They Kill: The Discoveries of a Maverick Criminologist (New York: Vintage, 1999), p. 134.

5 Truman Capote, In Cold Blood (New York: Random House, 1965), p. 347.

6 A gang member, quoted in Leon Bing, Do or Die (New York: HarperCollins, 1991), p. 56.

7 Diana Scully \& Joseph Marolla, Convicted Rapists' Vocabulary of Motive: Excuses and Justifications, in Paul Cromwell ed., In Their Own Words: Criminals on Crime $\left(4^{\text {th }}\right.$ ed. Los Angeles: Roxbury, 2006), p. 151.

8 Id.

9 Id., p. 153.

10 Id., p. 156.

11 See Margaux Fragoso, Tiger, Tiger: A Memoir (New York: Farrar, Straus \& Giroux, 2011) (describing long-term sexual abuse of a girl by a man who insisted they had a romance). For a classic literary treatment of the rationalizations of a child abuser, see Vladimir Nabokov, Lolita (New York: Random House, 1955).

12 Douglas W. Pryor, Unspeakable Acts: Why Men Sexually Abuse Children (New York: NYU, 1996), pp. 268-69.

13 Some perpetrators also express surprise at their own sexual conduct. "To them, a mysterious force took hold of their lives and controlled them more than they were able to control it." Pryor (1996), p. 267. Pryor calls this an "erotic surprise" that leads to an "erotic slide" into sexual contact. Id.

14 On the age of consent in the 19th century, see Joseph J. Fischel, Per Se or Power? Age and Sexual Consent, 22 Yale J. L. \& Femin. 279, 286 (2010). Estimates are that the average age of a girl's first period (menarche) was 15.3 years in 1840 in the US and Europe. In the US at the turn of the $21^{\text {st }}$ century it was 12 years, 4 months. William Saletan, The Mind-Booty Problem: Rethinking the Age of Sexual Consent, Slate, Sept. 27, 2007.

15 See United Nations Population Fund, Child Marriage, found at www.unfpa.org/ child-marriage; Human Rights Watch, World Report 2016, Ending Child Marriage, found at www.hrw.org.

16 On noncriminal psychopathy, genetics and evolutionary advantages, see James Fallon, The Psychopath Inside: A Neuroscientist's Personal Journey into the Dark Side of the Brain (New York: Current, 2013). For an introduction to current research on psychopathy and implications for moral and legal responsibility, see Handbook on Psychopathy and Law, eds. Kent A. Kiehl \& Walter P. Sinnott-Armstrong (New York: Oxford, 2013). See also Robert D. Hare, Without Conscience: The Disturbing World of the Psychopaths among Us (New York: Guilford Press, 1999). 
17 For a powerful account of how social structure and social norms can support violence, see Geoffrey Canada, Fist Stick Knife Gun: A Personal History of Violence in America (Boston: Beacon, 1995).

18 Dave Cullen, Columbine (New York: Twelve, 2009); Samuel H. Pillsbury, Why Psychopaths Are Responsible, in Kiehl \& Sinnott-Armstrong (2013).

19 Cullen (2009), p. 182.

20 Cullen (2009), p. 216.

21 Obviously there is major tension here between the idea of moral principles, which are supposed to be timeless, and historical change. Looking back on slavery, for example, we can see that social norms have dramatically changed about its acceptability, but morally, it has always been wrong. There is no final way of resolving this tension. In fact, social norms change over time. Moral norms should not.

22 On the history of rape law reform, see Aya Gruber, Rape, Feminism and the War on Crime, 84 Wash. L. Rev. 581, 586-603 (2009); Michelle J. Anderson, From Chastity Requirement to Sexuality License: Sexual Consent and a New Rape Shield Law, 70 Geo. Wash. L. Rev. 51 (2002).

23 This may be seen in the reluctance of American criminal law to adopt any liability for a person who refuses to come to the aid-in any way-of a stranger in dire need of assistance. See John Kleinig, Good Samaritanism, 3 Phil. \& Pub. Aff. 382 (1976). 


\section{3}

\section{MISJUDGING WRONG}

We expect evil to be obvious. Once we know what has been done, by whom, and why, we expect the awfulness of the worst deeds to be apparent. Their evil will hit us over the head, punch us in the gut; we will feel the chill in our bones. True evil will out. Right?

And yet, astonishingly, over and over again, we see that evil is missed in real life. Looking back, we see violent deeds that we now condemn in the strongest moral terms were missed by many at the time. We discover that conduct which now seems perfectly loathsome, was previously seen as justified, in whole or in part. We find serious and surprising failures to recognize and condemn wrongful violence, particularly sexual violence.

Americans expect, because we see ourselves as a good people and believe our legal system to be just, that our moral and legal judgments about wrongdoing will be clear, strong and fair. We believe that gender, class and race differences will be irrelevant to the decisions of police, courts, or any institution of criminal justice. This is the United States of America, where due process and equality under law are holy writ. This is 21 st century America, a nation that has elected a black president (twice) and is formally committed to racial equality under law.

And yet, at every stage of the criminal justice process we find evidence that because of race, some persons are presumed dangerous or bad and receive harsher treatment than others in the same situations. They are discriminated against. The nation's commitment to fairness and equal treatment is mocked by signs that ageold race prejudices still affect many critical decisions in criminal justice. 
The problems of racial bias in judging and nonrecognition of sexual violence would seem to be quite different. And in many respects they are. And yet they can be traced to the same moral mistake: an assumption about who can be trusted and who cannot.

This chapter is about how we frequently rely on good guy versus bad guy stories to make moral and legal judgments about right and wrong. Sometimes this reliance is conscious and apparent. Sometimes it is unconscious and takes investigation to discover. Regardless, serious injustice can result. Although these stories of the good and the bad feel good and seem right, they can lead us badly astray.

This chapter introduces another part of the personal challenge of justice in America. So far we have looked at the harm done to victims of wrongful violence (Chapter 1) and at the culpability of violent perpetrators (Chapter 2). Now we look at judges of wrongdoing. By judges I mean not just the black-robed jurists who preside in the criminal courtroom, but everyone who passes judgment, formally or informally, on serious wrongdoing in America. In other words, everyone. All of us.

\section{The Story We Love: Good Guys vs. Bad Guys}

This is the story we love. This is the story that thrills the American heart. Good guy takes out bad guy. An example from a cable television drama, Southland, about patrol officers in the Los Angeles Police Department:

The story, or episode if you prefer, opens with a book-laden teen shot to death while walking to school. A head-shaven, heavily tattooed Latino leans out the passenger window of a car and unleashes a torrent of bullets in an entirely unprovoked attack. The climax of the episode is the shooter's arrest, which seems to resolve matters until the arrestee manages to grab a gun from a nearby police officer and shoots yet another officer in the stomach. The protagonist of the show, Officer Ben Sherman, on his very first day on patrol as a rookie officer, pulls his gun, shoots and kills the man. From the sequence of events, there is no question, legally or morally: this is a justified homicide.

Afterwards, Officer Sherman sits by himself on the curb, seemingly stunned. His training officer, Sgt. John Cooper, a long-time veteran of the force comes up to him. Summing up their day of patrol work, Cooper says: "It's relentless and it gets to you. And it seems like it changes nothing ... But every once in a while, you get to take a bad guy off the streets for good. And that, my friend, is God's work."1

Oh, how we love this story. Good guy takes out bad guy. Justice done.

The moral message of this story seems irrefutable. But that is because the storyteller chose to tell an expressly moral tale: a melodrama, in fact. The characters have been presented as good or bad and their actions as clearly good or bad. But 
how often does real life provide such moral clarity? How often do we encounter individuals who are fully good or bad?

What seems obviously right or wrong in a story like this can be much more difficult to discern in real life. Worse, the assumption that moral judgment requires a sorting of persons into good and bad encourages factual and moral oversimplification that may fatally skew final judgment.

Here we will look at two different patterns of mis-judgment about criminal responsibility that stem, at least in part, from assumptions about the moral character of the persons involved. First we will look at nonrecognition of sexual violence by persons otherwise greatly trusted. Second we will look at nonrecognition of racial bias by persons we want to believe are unbiased.

\section{Nonrecognition, Part I: Sexual Violence by the Trusted}

In the last ten years, the United States has seen repeated major controversies concerning serious acts of criminal violence by members of highly respected institutions and organizations. In each instance, the institutions or organizations reacted slowly and ineffectively to multiple credible reports of great wrong. Reports of rape and sexual abuse, aggravated assaults, and unjustifiable homicide were received, but institutional denials and cover-ups followed. In each instance, the pride of the institution, the camaraderie of its members, and fear of collective shame at the public revelation of wrongdoing, prevented recognition of serious wrongful violence. In each case the institution or organization insisted, over and over again, that its own internal responses were sufficient to address the problem and that outside interference was unwarranted and potentially dangerous.

This has been the pattern of response to reports of sexual assaults in the US military. This has been the pattern of the controversy surrounding sexual assaults on American college campuses, at elite private schools and sexual violence and harassment in the media and entertainment industries. This has also been the pattern, with some variations, of controversies over unjustified violence by police officers against young minority males, most of them African American, in a number of US cities.

In retrospect, the failure in each instance to recognize serious violent wrongs is surprising.

We might well think: there is no way that women serving in the Army, Air Force or Marines would regularly face sexual harassment, sexual abuse and rape from fellow servicemen and officers, right? And if it happened, superior officers would step in and make sure that wrongdoers were held accountable, and victims protected, right? From what we know about the military, these are natural enough assumptions, though proven wrong in recent years over and over again. 
There is no way that women attending institutions of higher learning are regularly being sexually assaulted by classmates, right? Parties may get out of hand, but there's a line everyone knows can't be crossed. And if it is, colleges and universities will investigate, or police will investigate, so that justice will be done, so that perpetrators will be held to account. Even if those perpetrators are high-profile athletes. Right? Quite wrong; too often, quite wrong.

The unjustified violence that black men have suffered at the hands of police has been known for years. Individual claims of brutality have been made and, especially in the context of civil lawsuits, have been officially credited for many years. But still most Americans have viewed these as highly exceptional, attributable to a very few misbehaving officers. The public, and police departments, and prosecutors, have argued that the vast majority of police conduct themselves with restraint and respect for the law, even when that is extraordinarily difficult. Killing or brutalizing minority males just because they ran from police or were not properly respectful or compliant - many Americans believed that was a relic of the past. But with new video evidence, recognition of the problem has grown.

In these three instances, we see institutions and organizations that command broad respect from the American public - the military, universities, and policeexperiencing great difficulty recognizing their own complicity in criminal violence. Only when the larger society started to hear and believe the accounts of victims, only when the evidence of wrongdoing became irrefutable, did a basic shift in community views occur-to the extent that it has.

Recognizing wrong in retrospect is easy. It is so obvious, now. To learn from past mistakes, though, we need to go back in time and look at the original conditions of nonrecognition to see how it happened. In this quest, I look at a particularly dramatic example of nonrecognition, involving child sexual abuse.

\section{A Case Study in Nonrecognition: Child Sexual Abuse by Catholic Priests in America in the Late 20th Century}

Viewed from a distance, few institutions might have seemed better equipped to recognize sexual wrongs done to children than the Roman Catholic Church in America. An organization devoted to human spirituality, deeply concerned with good and evil, right and wrong; an institution whose mission included the moral education of children and whose leaders often decried the soul-dangers of immoral sexual conduct, surely this institution would recognize the seriousness of the wrong of adults sexually abusing children and young teens. Except that here the adults were priests and the abused were young people in the church's care. We will see that the institutional church displayed a blindness to the most serious wrongdoing, 
including the forcible rape of very young children that is startling in retrospect. There was a fundamental failure to recognize evil. ${ }^{2}$ The question is why.

I do not offer anything like a full explanation for child abuse committed by priests in the Roman Catholic Church in the US in the late 20th century, or of the cover-up of their conduct undertaken by the national and global church. The scope of the scandal is too great and the contributing factors are too many and too complex. The scandal can serve, though, as a useful example of collective moral blindness. The failures of the church and those associated with it can provide insight into what we need to recognize and properly judge violent wrongdoing.

I need to emphasize that while the story told here is specific to one religious institution, it is not told to condemn a religion or institution. I am clergy myself and know full well that sexual abuse by clergy occurs across all denominational and faith boundaries. Nor is it by any means limited to religious institutions. ${ }^{3}$ As someone who works at a Catholic institution of higher learning and who has had Catholic leaders, both lay and clergy serve as some of my most important professional mentors in ministry, I know that the priest scandal is unrepresentative of the church. But this particular story remains important because in the well-documented, systematic failures of a venerated institution we can see the difficulty of recognizing evil deeds committed close to home. It's a particularly dramatic example of a deeply human resistance to recognizing, or punishing serious wrongs by those who are seen as especially Good.

\section{A Pattern of Nonrecognition}

Throughout the latter part of the 20th century, priests and bishops in the Catholic Church did not recognize the seriousness of the harm caused by sexual contact between priests and minors in their care. The church did not view it as egregious wrongdoing. Again and again the church treated child molestation by priests as unfortunate misconduct but not sufficient to merit reporting to criminal authorities, or permanent removal of a priest from pastoral responsibilities. Meanwhile priest abusers, as is common for perpetrators of such offenses, did not see their conduct as especially wrongful or harmful. ${ }^{4}$ Often they blamed any conceded sexual conduct on troubled or overly-affectionate youth. ${ }^{5}$

When parents learned of the abuse of children and complained to the church, the church usually responded by removing the priest from the parish (the local church). Based on church representations, parents often believed that the church took effective steps to prevent the priest from ever abusing minors again. That was rarely true. Often the priest was given some form of psychological treatment. Church leaders did not evaluate the effectiveness of this treatment, however, and in many 
cases did not listen to expert warnings that the individual might reoffend. The church then usually returned the priest to active ministry in another parish or diocese, never informing parishioners of the priest's prior history of abuse. ${ }^{6}$

The church largely treated priestly child abuse as a problem in personnel management, similar to that posed by alcohol or substance abuse. The priest needed pastoral care and medical treatment for his condition. Once that was administered, he would be restored to the work to which he had been called by God. Significantly, the church rarely used moral terms, let alone criminal vocabulary, to describe the abuse incidents. ${ }^{7}$

The exact scope of the sexual violence committed by Catholic priests against the young in the United States will never be known, but it has been great. Some 6,100 priests in the United States, according to the church, have been "credibly" or "not implausibly" accused of sexual abuse. Church estimates are that some 16,000 minors may have been abused. ${ }^{8}$ Victims were both male and female, but predominantly male. Many served as altar boys. Some of those abused were very young, but it appears that the majority of the abused were adolescents aged 12-16. Many of the victims were chosen for their vulnerability. They came from singleparent or otherwise stressed families, who particularly welcomed the help of a friendly priest. Because the victims often came from troubled backgrounds, they were less likely to be believed if they complained of abuse. Abusers counted on this. They always do.

The damage done to mind and spirit was terrible. Sexual abuse by an adult, a "father" who used the trust and power of his church position to induce sexual activity in a child produced the devastation we might expect: confusion, shame and guilt, which often led to depression, educational difficulties, substance abuse, relational problems and even suicide. In some cases the abuse contributed to the victim later committing his own acts of child sexual abuse. ${ }^{9}$

We saw in Chapter 1 how wrongful violence wreaks havoc on self-identity. That is especially true with child sexual abuse. For the boys who were molested or raped, the actions of the priest inevitably raised difficult questions about their own sexual identity. The abuse often represented their first sexual contact. It was unwanted and deeply strange but it could not be simply put aside. No one can just put aside their first sexual experience. Certainly not when it is abusive.

"It tears your soul right out of you," said a victim of priest molestation. ${ }^{10}$

"He took everything. He took my innocence. He took my spirituality. He took my purity," said another about the priest who abused him. ${ }^{11}$

The harm to the families of the abused was great as well. "Everything you have taught your child about God and safety and trust—it is destroyed," said a parent whose child was abused. ${ }^{12}$ 


\section{Failure to Appreciate the Harm of Child Sexual Abuse: The Need for Social Understanding of Wrong}

Defenders of the American Catholic Church in the child abuse scandal have said that the church did not fully understand the problem of child sexual abuse when the first claims were made, because no one did at the time. There is some truth to this for cases that arose in the 1960s and 1970s. Compared to contemporary understanding, few professionals in or out of the church understood much about child sexual abuse at the time. With respect to cases that arose in the 1980s and later, though, the church did not so much lack information about child sexual abuse as it lacked an appreciation of the terrible harm of this conduct.

We often assume that wrongdoing will be obvious to any person with a conscience. Any person of good character will recognize serious wrongdoing. In practice, though, morality depends on social as well as individual values. Reliable recognition of wrong requires social-moral education in wrong. Or to put this another way, morality is more relational than we think. Individual views of right and wrong are strongly influenced by the views of those around us.

Recent history provides many examples of how changing views of certain persons and social roles have led to greater recognition of serious wrongs. For example, in the last quarter of the 20th century in the United States, social views of women and children changed significantly. Their personal experiences came to be valued as they had not been before. As a result, attitudes towards their victimization changed. Recognition of the wrongs of domestic violence, sexual assaults against acquaintances and child abuse all dramatically increased. What previously were seen as private matters, or minor public wrongs, came to be recognized as crimes that required vigorous investigation and prosecution. Attitudinal changes provoked new criminal legislation, new levels of crime reporting, new procedures in investigation and adjudication, altered prosecutorial policies and increased punishment. Similar changes have occurred in attitudes towards race discrimination and sexual harassment. In all instances, the harmful conduct was known to exist before, but changing social appreciation of its harms led to increased moral and legal recognition of its wrongfulness.

Public understanding of the prevalence and harms of sexual crimes against children is a relatively recent phenomenon in the United States. Even in the behavioral sciences, the actual prevalence of incest, sexual molestation and other forms of child abuse was not well recognized until the early 1970s. Sigmund Freud famously decided in the late 19th century that the many accounts of incest that he heard from his female patients must be the product of their unconscious imaginations, because the conduct could not possibly be as prevalent as their stories suggested. ${ }^{13}$ 
His denial of the problem was typical of mental health professionals for much of the 20th century. Not until the 1960s and early 1970s, did behavioral scientists, many influenced by the feminist movement, undertake a serious study of trauma and systematically explore the prevalence and consequences of sexual assault and childhood sexual abuse in America. ${ }^{14}$

Therefore it is true that prior to the 1980s the Roman Catholic Church in America did not have anything like the understanding we have today of the prevalence and harm of child sexual abuse. Most Americans did not either. We can see this in the parents who unwittingly allowed priests unlimited access to their children under conditions that today would seem highly suspicious. It was also true for child victims, who had no clue what was happening, or its fundamental wrongness, when a priest began to use them sexually. ${ }^{15}$ They had not received any education in the possibility or dangers of sexual abuse by adults and certainly not by priests.

Public understanding of the prevalence and harms of child sexual abuse came with popular television dramas on the subject beginning in the mid-1970s. Television talk shows introduced the phenomenon to a broad audience. Prize-winning books and movies featured child sexual abuse in the early 1980s. ${ }^{16}$ This new understanding of abuse did not permeate the Catholic Church, however. Throughout the late 20th century, Catholic Church leaders failed to appreciate both the prevalence and the harm of child sexual abuse.

And yet there were rules in place against the conduct and there were specific warnings. The church had sanctions against child sexual abuse by priests going back to the $14^{\text {th }}$ century; these were codified in the early 20 th century. ${ }^{17}$ Leaders at all levels of the American Catholic Church received repeated warnings from Gerald Fitzgerald, who founded and ran Servants of the Paraclete, which treated priest sex offenders. As early as 1952, Fitzgerald had warned that priests with a history of child abuse should be defrocked (removed from the priesthood) because of the danger of their reoffending. ${ }^{18}$ In 1985, an internally commissioned report provided a clear picture of the problem of clergy abuse in the American Catholic Church. ${ }^{19}$ And yet church leaders still resisted acknowledging the depth and breadth of the problem. Pronouncements on the subject often dwelled more on the plight of troubled priests than the suffering of their victims. Euphemisms and general terms for priest misconduct were used to describe the sexual abuse of children. ${ }^{20}$ Church leaders often sought to shift the blame from abusive priests to secular culture and even to the enticements of child victims. Sorely lacking was an appreciation for the soul-devastation of this abuse.

And so the church continued to treat victims with suspicion. Milwaukee Archbishop Weakland: 
We could easily give a false impression that any adolescent who becomes sexually involved with an older person does so without any degree of personal responsibility. Sometimes not all adolescent victims are so innocent; some can be very active and aggressive and often quite streetwise. ${ }^{21}$

The view from Rome often blamed a sexualized secular (American) culture. Papal spokesman Joaquin Navarro-Valls:

One would have to ask if the real culprit is not a society that is irresponsibly permissive, hyperinflated with sexuality and capable of creating circumstances that induce even people who have received a sound moral foundation to commit grave immoral acts. ${ }^{22}$

In their lack of effective response and occasionally in their words, church leaders made clear they did not comprehend the harm involved. One cleric was quoted as explaining that the reason that he did not confront a priest for having sexually abused a boy was: "Little boys heal." 23

\section{The Pernicious Power of Personalized Morality: Priests as the Ultimate Good Guys}

Personalized morality, otherwise known as good guys v. bad guys thinking, centers moral judgment on character. It assumes that once we know a person's moral character, we have a reliable guide to that person's moral conduct, past, present and future. This point of view is not unknown in criminal justice. Police and prosecutors often see themselves as the good guys, going after the bad guys. In the late 20th century, many American Catholics saw their priests as the ultimate good guys. Indeed, that was church theology. "We were taught they were Christ's representative on earth, and that's a direct quote. The priest would walk in and nuns would bow," said a man who had been abused as a boy by a priest. ${ }^{24}$

In the Catholic Church, the priest is part of the apostolic succession that goes back to St. Peter. He has special spiritual and moral authority. Priestly ordination grants authority to consecrate bread and wine at communion, hear confession and grant absolution for a sinner, baptize, marry and anoint the sick. Priests have special powers and have often been viewed as having an especially exalted moral and spiritual character. Historically this gave priests special moral authority with parishioners, young and old, with fellow clergy and even with secular legal authorities. They were special because they were especially good. 
This perspective made recognition of serious personal wrongdoing by priests extremely difficult. For some, it was literally unthinkable. Catholic parents, youth, lay leaders, police and lawyers and judges all found allegations of priest misconduct hard to believe and as a result found ways to avoid full acknowledgment. Often victims told no one. Or if they told, they were not believed. Especially in the early years of the scandal, parishioners frequently shunned the families of victims who complained about priest abuse, blaming them for disturbing the community with allegations that could not be true (meaning that the speaker could not believe them). ${ }^{25}$

If lawsuits were brought, they were usually settled quietly. For many years the church insisted that, in return for money paid as compensation, victims and their families had to sign confidentiality agreements. These required them to keep quiet about what had happened. Judges often granted church requests to seal court files that contained evidence of priestly abuse as part of settlements. ${ }^{26}$ This prevented the public from learning about what had happened. Even when accounts of priest abuse cases made the news, they were treated as isolated instances. It took years for victim advocates, both lay and legal, along with investigative journalists, to convince the public of the depth and extent of the problem. ${ }^{27}$

\section{Clergy Denial: The Power of Belonging, or, Fear of Not Belonging}

Within the church, clergy knew that some priests were abusing children. They knew, as organization insiders usually do, that some members were acting very badly. From the beginning, priests and bishops had the best information about what was occurring. They received firsthand complaints from families and children. Yet their responses were ineffective and kept entirely within church walls. There are reported instances of clergy observing unmistakable signs of a priest's sexual contact with a child and simply turning away without issuing a reprimand or reporting it to either church or civil authorities. ${ }^{28}$ Why? Why did those who knew the most about the problem, and who had committed themselves to caring for others as their life work, who had undeniable evidence of clergy misconduct, do so little about such terrible wrongs? Was it because of their bad character? Or was their moral failure also relational, a product of social context?

We all live within circles of close connection. Those who are closest to us actually form a part of us. These are the people who we are most likely to defend against others, however we might blame them ourselves. These are the people to whom we belong. It is very hard to see the people to whom we belong as anything besides good. It is even harder to call them out publicly for serious wrongdoing.

The Catholic priesthood is an all-male community with powerful ties of belonging between members. To join requires enormous personal sacrifice. Men 
must give up the opportunity for material wealth, must give up the ability to choose their own place of work and residence, must promise to give up sexual relationships, romantic love and the ability to have children. Once ordained, fellow clergy become family. ${ }^{29}$ Like other insular, elite and traditionally all-male professional groups such as the police and the military, the Catholic clergy has its own esprit de corps which includes a commitment to look out for each other. Clergy belong to each other.

Much the same is true for bishops. Within the church, bishops are charged with directing and caring for priests. In church teaching, bishops are the shepherds and priests are the sheep of their flock. As John Roach, Archbishop of St. Paul (Minnesota), put it in his testimony: "I want to help people, but I really want to help priests." Bishops also share directly in priestly solidarity as they are priests themselves. ${ }^{30}$

For Catholic clergy, recognition of the full wrongdoing of pedophile priests involved world-threatening consequences. It meant siding with strangers against family. Full recognition would require admissions that would open members of the church family, and the family itself, to public scandal. ${ }^{31}$ The reporting clergy member's advancement within the church would almost certainly be endangered. He would likely face social ostracism from his colleagues, who were also family. So many avoided full recognition. They turned away from the worst indicators of wrong. ${ }^{32}$

As part of their vocation, priests must avoid any actions that might cause scandal to the church. This aspect of ecclesiology (church theology) was understood by some clergy not just to give permission for keeping scandalous information from the public, but actually to require it. The proud church should never be shamed. Of course, in the end, this is exactly what happened.

It's not so hard to imagine something similar in our own lives. Imagine what it would be like to report a family member for a criminal wrong in a family business that would subject the entire family to severe criticism and social ignominy. Imagine what it would be like to call out an old friend or colleague for conduct that would lead to his public humiliation and incarceration. Imagine what it would take to do this knowing that speaking out would jeopardize your place in your family, your work community or your social group. Imagine doing this knowing that afterwards, you might never belong again.

\section{Good Guy Status and the Refusal to Punish}

A failure to recognize wrongdoing was central to the church's child abuse scandal. But equally important was a failure to punish wrongdoers. To this day, the church's 
reluctance to publicly punish abusive clergy and complicit or lax supervising bishops generates serious public criticism from abuse victims and their supporters. ${ }^{33}$ The Catholic Church has traditionally responded to clergy abuse with medical and pastoral counseling of offenders, by repentance and forgiveness, but rarely has the church affirmatively sought public revelation of wrongdoing, followed by retributive punishment. There are theological and institutional reasons for this I will not explore here. Instead, I use the church's resistance as an example of a more general resistance to publicly condemning and punishing wrongs by those close to us.

The Rev. John J. Geoghan was one of the most prolific and destructive pedophile priests in the history of the American church, preying primarily on children in the Boston area. In the mid-1990s, Cardinal Bernard F. Law wrote a letter to Geoghan granting his request for early retirement from active ministry. At the time of the letter writing, the Cardinal was well aware of Geoghan's wrongdoing with children, having dealt with abuse complaints against him for years. He had known that Geoghan was likely involved in the sexual abuse of multiple children as early as 1984. ${ }^{34}$ The Cardinal wrote to Geoghan in 1996:

Yours has been an effective life of ministry, sadly impaired by illness. On behalf of those who you have served well, and in my own name, I would like to thank you. I understand yours is a painful situation. The passion we share can indeed seem unbearable and unrelenting. We are our best selves when we respond in honesty and trust. God bless you, Jack. ${ }^{35}$

How could a history of sexually molesting children be described as ministry "sadly impaired by illness"? Could this be just a medical problem? Where was the moral condemnation of this most immoral conduct? Where was the determination of moral or legal responsibility?

The church had two basic responses to credible allegations of child sexual abuse by priests: the medical and the pastoral. The medical response was what the church emphasized in defending itself to outside critics. The pastoral response reflected its own deepest beliefs about ministry.

Church leaders often said that in returning abusive priests to active ministry, they relied on medical experts who assured them that this was safe. For example, responding to criticism of how he handled child sex abuse allegations against priests under his supervision, Cardinal Edward M. Egan declared in 2002: "Over the past 15 years, in both Bridgeport [Connecticut] and New York, I consistently sought and acted upon the best independent advice available to me from medical experts and behavioral scientists." 36 Critics have questioned the extent to which church leaders like Cardinal Egan really relied on medical expertise, pointing out the lack 
of qualifications of some doctors performing priest evaluations, and the church's failure to heed the warnings of mental health professionals about the likelihood of reoffending. For our purposes, though, what is striking is that an institution devoted to moral and spiritual understanding turned to behavioral science as one of its main resources for responding to sexual wrongdoing. The church frequently used medical treatment of abusive priests instead of individual moral or legal responsibility. Until very recently, there was no reporting of abuse incidents by priests to legal authorities, which meant wrongdoers were not held criminally responsible. Nor was there any imposition of personal responsibility in the form of public reporting to parishioners, past or present, of what the priest had done. Nor was there any requirement of admission or apology by priests to victims or family or community as a whole. The priest was only expected to confess-in confidenceto his bishop. This meant that for priest and church community alike, when the priest was reassigned to a new parish, it was as if the past abuse had never happened.

The church did not rely on medical treatment alone to handle the problem of abuse, however. It also employed traditional pastoral methods. Bishops emphasized compassion, confession and forgiveness in handling priest abuse claims. The abuse of minors by priests was seen by American bishops as an occasion for "healing and reconciliation." ${ }^{, 37}$ Prayer, confession and forgiveness were central ways of handling sinful conduct by believers, especially priests. "The old theory was, "Make a good confession and sin no more'. We never realized that it was a disease," said Bishop Robert N. Lynch. ${ }^{38}$ In this process, forgiveness wiped the individual's moral slate clean.

The commitment to forgiveness is deeply rooted in church theology. It often overrode basic norms of individual responsibility in responding to clergy abuse. As one monsignor said, trying to explain why he allowed a priest under his supervision to take children on overnight trips even after he heard complaints that the man had made sexual advances to boys that he was counseling: "I am trained as a priest to forget sins." 39

A sense of the church's reliance on pastoral methods to handle abuse claims can be gleaned from an exchange of letters between Mary Gallant and church officials in Boston in the early 1980s. On August 16, 1982, Gallant wrote Cardinal Humberto Medeiros to demand that the church take effective action to prevent the Rev. John J. Geoghan from further sexual abuse of minors. Geoghan had molested seven boys in Gallant's extended family, including a four-year-old. The family had held an emotional conference with Bishop Thomas V. Daily of the diocese, at which they believed they received assurances that Geoghan would be removed from his post. Yet two weeks later, 
Geoghan was still working at their church. Gallant wrote: "It was suggested [at the previous meeting] that we keep silent to protect the boys - that is absurd since minors are protected under law, and I do not wish to hear that remark again, since it is insulting to our intelligence." Gallant recognized that taking criminal action against Geoghan would probably only result in a period of confinement for purposes of observation, but noted that at least then,

he would also be exposed. Parents would know then not to allow children near this type of person. In this case not only do they not know, but by virtue of his office he gains access [to boys] quite easily ... Regardless of what he says, or the doctor who treated him, I do not believe he is cured; his actions strongly suggest that he is not, and there is no guarantee that persons with these obsessions are ever cured. ${ }^{40}$

Cardinal Medeiros responded in writing, thanking Mrs. Gallant for her "candid expression of opinion concerning the priest of the Archdiocese of Boston who has caused hardship to your family and especially to several of the boys." $\mathrm{He}$ continued:

While I am and must be very sensitive to a very delicate situation and one that has caused great scandal, I must at the same time invoke the mercy of God and share in that mercy in the knowledge that God forgives sins and sinners indeed can be forgiven. To be sure, we cannot accept sin but we know well that we must love the sinner and pray for him.... Please be assured that I am speaking to the priest in order to find the most Christian way to deal with the problem with him.

Geoghan was sent away for treatment and then returned to ministry at a new church.

Two years later, Gallant wrote the next head of the Boston archdiocese, Archbishop Bernard F. Law to complain that Geoghan was back in active ministry in Dorchester, Massachusetts and engaged in suspicious activities, dropping off boys at their homes as late as 9:30 at night. ${ }^{41}$ Law wrote Gallant in response: "The matter of your concern is being investigated and appropriate pastoral decisions will be made both for the priest and God's people." 42

Geoghan was then transferred from Dorchester to a church in Weston, Massachusetts. The monsignor in Weston was informed of his history, but not the parishioners. Geoghan continued to abuse boys until he was finally removed from active ministry in 1996, an action taken in the letter quoted at the beginning of this section. 
In trying to help their wayward priests, bishops often described themselves as shepherds going after the lost sheep of their flock. ${ }^{43}$ Bishop Thomas V. Daily who had been the pastoral supervisor of Geoghan for some time, used this image to explain why he had consistently sought to help Geoghan and had not notified law enforcement or taken more punitive measures internally. "I am not a policeman. I am a shepherd," he said. ${ }^{44}$

I am a pastor who has to go after the Lord's sheep and find them and bring them back into the fold and give them the kind of guidance and discipline them in such a way that they will come back. I'm not a detective. ${ }^{45}$

But every member of a community has obligations to justice.

In 2002, Cardinal Bernard Law was forced to resign his position leading the Catholic Church in Boston because of public outrage at how he had handled priest abuse claims in his diocese. Following these revelations, Thomas H. O'Connor, a Boston College historian and a close-and sympathetic - observer of Cardinal Law expressed puzzlement at the lack of compassion that Law had shown for child victims during the scandal. O'Connor was puzzled because he had witnessed Law's deep compassion for human suffering in many other settings. O'Connor said:

I find this lack of compassion for the victims inexplicable because I don't see him as a man lacking compassion. It's just a blind spot of his. I don't know. He leaves me confused because he's capable of so much. How can a man with so much talent, so sophisticated in so many other areas, be so blind? ${ }^{46}$

O'Connor was in effect asking, how could this smart man be so stupid? How could this compassionate man be so callous?

Thinking relationally may help here. Cardinal Law was in close pastoral relationship with his priests. They were the sheep of his flock, the ones he cared for most. He naturally had compassion for them, and also for others to whom he ministered within the framework of his episcopal duties. When he encountered victims of priest child abuse, now adults, however, he encountered strangers who challenged his authority, spurned his pastoral care and, through their claims of wrongdoing, threatened his world. Given this, is it really so surprising that Law would respond with more concern for clergy and the church than for past victims of abuse?

Blame and punishment of violent wrongdoers is basic to criminal justice. I will argue this more extensively in Chapter 4, but for now the child abuse scandal in the Catholic Church should serve as an example that, whatever their merits (and 
they are many), apology and remorse and repentance and forgiveness, counselling and treatment cannot substitute for holding serious wrongdoers publicly accountable. Justice demands it.

\section{Nonrecognition, Part II: Unconscious Race Bias}

We turn now from them to us. We turn from the wrongful acts of others to mistakes in judging those acts. Specifically, we turn to race bias in criminal judgments. Race issues have been part of American criminal justice from the nation's beginning. Bias questions remain central to justice today. Can we make criminal judgments free from race prejudice? We mostly think we can.

The presumption of American law is that decisionmakers will use their lawful authority in a racially neutral fashion. Whether a police officer or a juror, a judge or a prosecutor, the presumption is that judgment will be rendered without regard to race, or any other group distinction. Unless there is strong evidence to the contrary, the decisionmaker is presumed to have acted fairly.

This presumption of nonbias may be necessary to a legal system that relies on the discretionary decisions of many individuals. But the presumption also operates outside the legal realm. If asked, most Americans will confidently deny being racist. We may have our flaws, but we are not bigots.

This presumption of race fairness may seem benign, but it lies behind some of the most damaging mistakes made in American criminal justice. It assumes that bigotry is a character flaw revealed by racially hostile or stereotypic words and actions. This misses the truth that race bias in criminal justice is: (a) primarily a social rather than an individual phenomenon, and (b) is more likely to involve unconscious than conscious bias.

Let's return for a moment to that Southland television episode described in the chapter's beginning. Recall this was where a rookie cop fatally shot an arrestee who had grabbed another officer's gun and posed an immediate threat to a group of police officers nearby. This was an arrestee who had already shot one officer, and who earlier had gunned down a student on his way to school. The legal prerequisites for justified homicide are met there: deadly force is used by the officer to thwart an immediate, unlawful threat of deadly force. Morally and emotionally, the rookie cop's actions seem fully justified. On its face, this judgment has nothing to do with race.

The fact that the two main protagonists in this episode, the rookie police officer and his sergeant, are white, and that the group of police officers gathered nearby are predominantly white, and that the arrestee - the person ultimately killed-is Latino, is irrelevant at law. And it should be irrelevant to our emotional responses as well. But is it? 
Let's change the races of the participants here-but nothing else. Assume that all persons acted as before. But now assume that the rookie police officer and his sergeant, are African-American, assume that the other police officers on the scene are predominantly African-American and Latino, and finally assume that the arresteethe person killed - is white. Does this scenario feel any different now?

Many people will say no, the new version is exactly the same as the original. Again, this is true as a matter of law, but I wonder about emotionally. Would white audiences react with quite the same sense of righteous satisfaction at the police use of force, if the police officers were black and brown and the person killed was white? It's hard to say, but I think I might have a more complicated emotional response. I might be less inclined, emotionally and morally, to shout Yes! at the fatal shooting in this revised version. Just because of race. Which is a deeply disturbing thought.

Here's the problem. Criminal justice decisions must be made based on imperfect information. Real-life incidents are not captured in full, graphic detail, even when there are video or audio recordings. We must assess who did what based on the information that we receive, which is often imperfect and incomplete. In judging responsibility, we have to draw inferences, make assumptions, reach conclusions. This effort is hardly unique to criminal judgment, however. We constantly make factual and normative judgments in our everyday lives. Is this salesperson telling me the truth about this product or service? Who do I believe between two friends who give radically different accounts of a conversation last week? Who can I trust at work? In these situations, we make the best judgments we can based on the information we have, and the information that we can independently develop. Understanding that we can always get it wrong.

In American criminal justice there is one kind of mistake about which we have long been especially concerned. This mistake tracks a deep fault in the nation's social structure. The effects of this error are particularly devastating to those who suffer mis-judgment. It's when race affects decisions about wrongdoing.

In the last generation, many who have studied race discrimination in criminal justice (and elsewhere) in America have come to the same conclusion: if we concern ourselves only with conscious race bias, we will miss the much bigger problem of unconscious bias. There is overwhelming evidence that in the contemporary United States, unconscious racial bias affects criminal justice decisionmaking. This is especially true for white decisionmakers, but is not limited to them. Conscious racial bias is also a problem, and in a Trump America arguably a greater concern than before, but my main focus here is on unconscious bias, because it is more prevalent.

The evidence piles up from years past and recent times, from all across the country. Decisions by New Jersey state troopers about who to stop on the highway 
as part of a drug interdiction program, decisions by prosecutors about who to charge in drug cases, decisions by police and judicial officials about who to target for minor offenses in Ferguson, Missouri, racially discriminatory policing in Baltimore, Maryland, decisions about juvenile arrests and commitments to juvenile facilities in the delinquency system, who will receive the death penalty in Georgia or Louisiana, and how parole decisions are made in New York State-all these appear to be affected in some instances by race. ${ }^{47}$

Many express dismay at this evidence. There are prohibitions on racial discrimination in federal and state law. The US Constitution provides powerful protections against racial discrimination in the equal protection clause of the Fourteenth Amendment, and the provisions of the Fourth, Fifth, Sixth and Eighth Amendments that apply to criminal cases. And yet racial bias persists in criminal justice decisionmaking.

Our difficulty in addressing unconscious race bias in criminal justice has much to do with our conception of racial wrong. By assuming that racism involves conscious wrongdoing, we make it seem exceptional. Most people (most people I know anyway) are good-hearted and therefore unbiased. But if race bias is unconscious and represents a shared tendency of many rather than the character trait of a few, then we will miss its actual role in criminal justice, over and over again.

\section{Legal Views of Racism in Criminal Justice: The US Supreme Court}

Racial discrimination is a legal as well as a social concept. In the past, American law and courts played a critical supporting role in race slavery and race segregation. After World War II, legislation and judicial decisions have both reflected and instigated changes in racial attitudes and practices in the nation. Throughout our history, no court has been more important in setting basic legal rules relating to race than the United States Supreme Court.

Under the leadership of its liberal majority in the 1960s and early 1970s, the Court engaged in what has been called the Procedural Revolution, in which federal constitutional rights were applied to the states. Decisions like Miranda v. Arizona on the rights of the accused in police interrogations, Mapp $v$. Ohio, on the right to be free from unreasonable searches and seizures, and Duncan $v$. Louisiana on the right to a jury trial, transformed criminal procedure in state courts, where most criminal cases are handled. All were presented as largely nonracial decisions. ${ }^{48}$ The constitutional rights involved did not mention race, and for the most part the Court did not discuss race in the rationale of its decisions. And yet, these decisions were rendered during the height of the civil rights movement, when everyone understood that those most affected by law enforcement abuses were African-American. 
In later years, a more conservative Court cut back on many earlier interpretations of federal constitutional rights. But the same Court actually extended the Constitution's reach with respect to race discrimination in criminal justice, at least with certain kinds of discrimination.

Where the Court found racially biased individuals whose actions may have affected the case outcome, it intervened. So, for example, in Batson v. Kentucky, the Court for the first time prohibited prosecutors (and in later cases defense attorneys) from using race in selecting jurors in a criminal trial. ${ }^{49}$ The Court has prohibited state prisons from segregating prisoners by race. ${ }^{50}$ The Court has recently allowed lawyers to engage in post-trial questioning of jurors about racially biased remarks made in the jury room, even though evidence law generally bars post-trial inquiry into jury comments. ${ }^{51}$ Recently in Buck v. Davis, the Court overturned a death sentence in a Texas case where a psychologist had testified that the defendant might be more dangerous in the future because he was black. ${ }^{52}$

The recent Buck decision provides a window into the Court's current thinking on race discrimination in criminal justice. Chief Justice John Roberts, writing for the six justice majority, wrote that the psychologist's opinion, which was actually introduced by defense counsel, "coincided precisely with a particularly noxious strain of racial prejudice, which itself coincided precisely with the central question at sentencing." Roberts noted that while the discussion of race in the case was relatively brief, it remained significant: "[s]ome toxins can be deadly in small doses." 53

From these decisions we see that the Court takes the problem of race bias in criminal cases seriously, at least where there is evidence that lawyers or decisionmakers in the case were biased. But where there is no clear evidence of individuals who may have been affected by racial prejudice, the Court will find no constitutional violation, even if the case fits a general pattern of biased decisionmaking.

Many have complained that police engage in racial profiling in deciding whether to stop persons. The phrase, "driving while black" describes this racialized tactic. But is it actually illegal? If the actual motivation is shown to be racial, it might be, but that question will rarely come up, because under current law, as long as the police can articulate a legitimate, nonracial reason for their actions, their actions will be deemed lawful. A broken tail-light or expired registration tag can provide the lawful basis for a stop even if the real reason for the stop was an officer's suspicion of the driver or the car's occupants. The Fourth Amendment does not require any inquiry into actual police motivation as long as reasonable suspicion or probable cause concerning violations of law can be shown. ${ }^{54}$

Complaints about race bias in charging decisions by prosecutors have met with similar treatment by the Court. Under current law, prosecutors are presumed to 
have properly exercised their discretion about whether to bring criminal charges. Unless a defendant can show that charges were brought with a racially discriminatory purpose, the decision to charge is constitutionally unreviewable. ${ }^{55}$ In practice, claims of selective-meaning discriminatory-prosecution almost never succeed.

A similar deference to legal decisionmakers has informed the Court's view of race bias in death penalty decisions. The last major systemic attack on capital punishment that reached the United States Supreme Court was based on a sophisticated empirical study showing the effects of the race of the defendant and victim on death penalty decisions in Georgia. The evidence of race bias was statistically strong, but the Court majority found it insufficient to overturn the African-American defendant's death sentence. The Court held that there must be specific evidence of race discrimination in the case at hand; indications of race bias based on data from many other cases were insufficient.

This is where we stand today. If there is proof of particular racist behavior by a decisionmaker or legal officer in a case, the Court takes it seriously. If there is only statistical evidence that a decision may have been affected by bias, there will be no legal remedy, however. Or to put this another way, to be actionable, the racial wrongs must come from conscious choices by decisionmakers in the case; indications that they might have been affected by unconscious bias will not suffice.

There is a system-protective explanation for this approach. Intentional, case specific wrongs can be dealt with in case specific ways, without threatening the criminal justice system as a whole. But if the Court allowed inquiry into the unconscious race bias of police, prosecutors, judges or jurors, official attention might soon shift in many cases from the alleged wrongdoing of the accused to decisionmaker biases. And because such bias is widespread, the results of this inquiry could undermine many prosecutions, with potentially devastating effects on public trust in the criminal justice system and the Court itself. The Court does not want to risk all of that.

There is another explanation for the Court's approach, though: it reflects the prevailing American view that racism is all about individual character. Racially speaking, it's about whether one is good or bad. And that, I think, is clearly wrong.

\section{Race Bias and Individual Character: Back to Good Guys vs. Bad Guys}

As with other evils, the popular view of racism conjures examples of malevolent, intentional wrongdoing. The violent redneck Southern sheriff of late $20^{\text {th }}$-century movies, or a white supremacist in full Nazi regalia provide the poster figures of American bigotry. In public discourse, racism is defined by individuals whose words 
or actions show that they make a qualitative distinction between people according to race. They make conscious choices that are racist.

To be called a racist today means that you hold racist beliefs and attitudes. Which swiftly leads to social condemnation of the person. In contemporary America, at least in many circles, this constitutes a particularly devastating form of character judgment. This is not like being called arrogant or deceitful or greedy or even cruel. This is worse. To be condemned as a racist is to have a character trait that many believe should disqualify the person from public respect and public office. It is so bad that not only is the person-labeled-a-racist the subject of public obloquy, not only is he or she expected to apologize quickly and profoundly (which may or may not be sufficient to satisfy critics) but any institution or office with which the person is associated must also quickly condemn the racism and, usually, take retributive action against the guilty party. Unless swift action is taken, the institution or office faces potential condemnation for condonation of the racism. In public commentary (and in Supreme Court opinions), racism is frequently described as a kind of virulent social virus that must be attacked, fiercely and massively, whenever it surfaces, for fear that it will otherwise spread far and wide.

We encounter here a kind of moral melodrama, in which a few bad actors carry the nation's burden of race guilt. Their bad character is condemned, perhaps making the rest of us feel better about our own racial characters.

Because being declared a racist carries such dire moral and social consequences, great efforts must be taken to avoid this fate. For whites, the whole topic of race becomes dangerous, best avoided when possible, or treated only with preapproved generalities. When accusations of bias are made in criminal justice, and some response is required, the pushback can be strong and emotional. We hear something like this (though it is not often spoken aloud): I'm not prejudiced and neither are most of the people I know (most police, most prosecutors, most judges, for example). Yes, there are some real bigots out there, and their conduct must always be condemned, but the great majority are conscientious and hard-working and committed to justice in the best sense. Don't you dare presume otherwise.

The contest over who gets labeled racist is a high-stakes moral contest. It's about nothing less than who is a good person in America. A good person is innocent of racial bias. A racist is a bad person. And so we are back to good guys and bad guys. If we are good (and surely we are) and if people like us are good (surely true as well), then we will be strongly inclined to trust the racially innocent explanations given by people like us.

The contest over who is good and who is bad, whether goodness or badness involves criminality or race, is also a contest over who belongs. The racist does not belong in modern, egalitarian America. This helps explain the need to describe race 
discrimination as exceptional and the product of intentional individual decisions, rather than the common and unintentional product of broadly accepted, but often unrecognized, cultural attitudes.

Once more we see the danger of trying to fit complex moral questions into a simple good guys versus bad guys account. To tackle our most serious problems with racial bias in criminal justice, we will need to change the kind of moral story we tell. We will also need to address our own fears.

\section{Race and Fear}

How much can someone be blamed for being afraid? In earlier ages, when warrior values prevailed and physical courage was held in high repute, unwarranted fear might be taken as a sign of cowardice, which was a great character flaw. In the modern era, where physical conflict is seen more in sports and on-screen entertainment than in ordinary life, where average lifespans are far longer and physical safety more expected and valued, we sympathize with those who fear for their physical safety. We think everyone should be safe and feel safe. This makes the confluence of fear and race a particularly difficult challenge for contemporary America. When race is involved, can we distinguish between fear that is based on objective facts about the situation and fear that stems from race bias?

We know that racial difference can dramatically and without justification exaggerate fear. Because of race- just because of race-certain individuals are seen as more powerful and more threatening. African American men are perceived as bigger, more muscular and more threatening than white men of the same size: a purely racial difference. ${ }^{56}$ Headline controversies involving race suggest the problem. The beating of Rodney King, the killing of Trayvon Martin, and many police shootings of unarmed young African-American men have provoked public controversy because in each the blackness of the person attacked seemed critical to the accused's perception of threat.

Every year in my first year Criminal Law class, we take up the case of Bernhard Goetz, dubbed the subway vigilante by the New York tabloids. ${ }^{57}$ On December 22, 1984, Goetz, who had been mugged several times in the past, carried an unlicensed pistol while he rode a New York City subway. Four young men entered the subway car where he sat. Goetz was white and of slight build compared to the four young men, who were African-American. One of the men approached Goetz and said, "give me five dollars." Goetz took this as a threat and responded by pulling out his weapon and shooting. (On at least one earlier occasion, Goetz had thwarted a potential assailant by just displaying his gun.) Goetz shot all four young men. Then he ran from the stopped subway car. 
The historical context of this case is important to understanding its outcome. The shooting happened at a time when violent crime was at its height in New York City and the criminal justice system was widely perceived as inadequate in its response. Police were overwhelmed; the court system was overwhelmed. No one felt safe.

The four young men shot in the subway car survived their wounds; one was left permanently paralyzed. Goetz later turned himself in to police in New Hampshire. He told the police that he had feared being "maimed" by the young men, even though none displayed a weapon or made an express verbal threat. He described his great rage at being threatened by them, and his desire to kill. "If I had had more [bullets] I would have shot them again, and again, and again ..."58

Goetz was charged with a number of crimes, including attempted murder. He was acquitted at trial of all charges except unlicensed possession of a gun. While there were contradictions and confusion in some of the witness testimony for the prosecution, and the one victim who testified for the state came across as threatening and hostile on cross-examination, the jury's verdict seemed to go well beyond the law of self-defense. Rather it seemed to reflect a judgment about good guys and bad guys, with the jury (predominantly, but not entirely white) sympathizing with Goetz's rage in response to four scary young black men.

I always ask my students some version of the following question. Imagine that you are the prosecutor in this case, and that you believe that the jurors may judge the alleged victims to have been more threatening than they actually were because of their race. What do you do about this? How can you address the risk of race prejudice in jurors without triggering a backlash by jurors angry at being accused of racism? Lastly, what might judges do to minimize the risk that racial bias would affect the verdict?

Once we acknowledge that race bias in threat assessment can be virtually automatic, working on a level below that of conscious decisionmaking, we can explore a less personally charged and less melodramatic approach to the problem than we normally take. We can see that the tendency is socially ingrained and widespread. It is not a sign of a person's exceptionally bad character. It does not signify overt racial hostility or stereotyping.

In the context of jury decisionmaking, we need to find ways to encourage jurors to examine more closely their own intuitions and judgments, without suggesting they are any more biased than the rest of us. We come back to the basic obligation of moral regard to see the uniqueness of the other person. Can we see the other as he or she is, can we see his or her actions as they actually are, rather than as we might instinctively fear or expect?

Most of us have racial attitudes and perceptions that we have received from upbringing or social milieu rather than consciously chose. We find ourselves 
judging others instinctively, trusting or fearing according to race (in part), without even thinking about it. Does the lack of conscious choice in this process absolve us from responsibility for our mistaken judgments? No. Of course not. The unconsciously biased person may not be the villain of a melodrama, but as in any ancient tragedy, she remains responsible for her actions.

The problem of race bias runs throughout American criminal justice. It will reappear as part of the story of mandatory life penalties in Chapter 5 and will be the main subject of Chapter 10. For now, race difference must stand as our single most important caution against assuming that what we feel to be the right in criminal justice necessarily is right.

\section{Conclusion}

We regularly miss the wrongs that "good" people do. We regularly misjudge the acts of persons we fear because of race. These are serious mistakes in doing justice. In addressing misjudgments like these we normally focus on how we got the facts wrong, which is important. What I have tried to do here, though, is to examine the beliefs and attitudes of judges (meaning many of us) that lie behind these mistakes. This has brought to light our predilection for good guys, bad guys moral analysis. This is not just a problem in recognizing sexual violence or race bias, though. The whole concept of good and bad people is mistaken.

Ultimately there are no good or bad people, only people who do good or bad at a particular time and place. We should hold responsible people who act badly: people who do violence when angry, fearful, frustrated, lonely, or greedy. Or decisionmakers whose judgments are affected by race, even if unconsciously. Even if we can make rough assessments of the goodness or badness of a person for other purposes, and of course we do, such generalizations are too dangerous to use in criminal judgments.

Good guys vs. bad guys is the stuff of cartoons, of superhero movies, of political demagoguery and the social-moral melodramas that comprise so much of contemporary public life. In criminal justice, the good guys, bad guys construct is especially prized by law enforcement. Indeed, for many in policing and corrections, the distinction constitutes an article of faith: we are good, they are bad. The distinction invigorates the rhetoric of both the political left and right. Anywhere that name-calling informs judgment, we are likely to find good guys versus bad guys. The identities of the supposed good and bad will change, but the construct, the dichotomy is the same. It's a great temptation to tell this story we love. To do real justice, though, we must change the story. 
Good guys versus bad guys stories are literally childish. They are the stories we tell small children to explain why bad things happen and why they need to be cautious in the world. As adults we should know better. We should see that dividing the world into good and bad people is an invitation to categorical moral judgments. We have seen for the last century where that can lead.

And yet we should never underestimate the lure of personalized morality. I will close with a quotidian example, from my daily commute. On the roads of Los Angeles, and likely on the roads of your locale, one often encounters the asshole driver. This is the driver who will not let you merge onto the freeway because she believes that she owns the space into which you would like to fit. Or the commander of the massive pickup truck who rides your bumper as if proximity could speed you on. Or the driver of the luxury German sedan who weaves in and out of tiny gaps in traffic at great speed, because- he believes - the more expensive the car, the more privileged the driver.

When I get aggravated at such drivers, which happens occasionally, I confess, I want to know who the driver is. Who is this person who acts like such a jerk? If according to the vagaries of traffic flow, I happen to pull alongside this driver in the next lane, I always want to look over to match a face with my moral judgment. Usually this proves disappointing, because instead of the face of a highway ogre, I see an ordinary person. She, or he, doesn't look terribly angry, he doesn't seem to be out to annoy or outrage, he doesn't radiate entitlement or arrogance. He's just another driver on the road, wanting to reach his destination as quickly as possible. He may drive like a jerk, but that doesn't make him, fundamentally, a jerk.

Although, let's be honest, it may be a sign. See how difficult this bad guys, good guys thing is to kick? It will return again and again on our justice journey.

\section{Notes}

1 Unknown Trouble, originally aired April 9, 2009, John Wells Productions, Warner Bros. Television.

2 I put this account in the past tense, not because the scandal is over or the problem is solved, but because I focus here on the worst instances in the United States nonrecognition of clergy sex abuse, and these do seem to be primarily in the past. In recent years the Catholic Church in the United States, has taken significant steps to address the problem of priest sexual abuse including changes in the selection and training of priests and a requirement of reporting credible allegations to civil legal authorities. Equally significant are changes in public perception of the problem, which means that abuse incidents are much more likely to be reported to the authorities and taken seriously. Time will tell how much difference these changes will make in the prevalence of clergy abuse, but they should make nonrecognition of child sexual abuse less likely than in the past. 
3 For example, there have been scandals involving long-term sexual abuse of students by teachers at elite private high schools. See Amos Kamil, Prep-School Predators: Unearthing a Secret History of Sexual Abuse at an Elite New York City Private School, The New York Times Magazine, June 12, 2012 and in Los Angeles public schools. See Richard Winton \& Howard Blume, Unlearned Lessons in School Sex Abuse Saga, Los Angeles Times, May 25, 2016. And in religious institutions of many faiths. See Rachel Aviv, The Outcast: A Child-Abuse Scandal in Borough Park, The New Yorker, Nov. 10, 2014 (Hasidic Jewish community).

4 A priest who confronted serial abuser John J. Geoghan about his abuse, reported a man who described the abuse of children in the casual manner of one who might describe a preference for "chocolate or vanilla ice cream." Investigative Staff of the Boston Globe, Betrayal: The Crisis in the Catholic Church (Boston: Little, Brown, 2002) (hereinafter Betrayal), p. 22.

5 Id., p. 24.

6 See generally, Betrayal; Michael D'Antonio, Mortal Sins: Sex, Crime and the Era of Catholic Scandal (New York: Thomas Dunne, 2013).

7 For example, a priest in 2001, speaking about the history of serial abuser John Geoghan, said: "Well, when he was removed from St. Brendan's in Dorchester, there was talk that he had been fooling around with kids." Betrayal, p. 23. The first direct papal mention of priest child abuse in America focused on the scandal to the church rather than the harm done to child victims. D'Antonio (2013), pp. 179-80.

8 D'Antonio (2013), p. 4.

9 See D'Antonio (2013), pp. 52-4. Retrospective studies indicate a correlation between having experiences of childhood abuse and later child abuse perpetration by males. That is, having been abused significantly increases the risk of becoming an abuser. The connection should not be overstated, however. The majority of child abuse perpetrators do not report a history of being abused themselves. See M. Glasser, et al., Cycle of Child Sexual Abuse: Links Between Being a Victim and Becoming a Perpetrator, 179 Brit. J. Psychiatry 482-94 (2001); Bureau of Justice Statistics, Lawrence A. Greenfield, Child Victimizers: Violent Offenders and Their Victims (1996), pp. iv, 6-7, https://www.bjs.gov/content/pub/pdf/CVVOATV.PDF.

10 D’Antonio (2013), p. 335.

11 Betrayal, p. 90.

12 Betrayal, p. 14.

13 See Russell A. Powell \& Douglas P. Boer, Did Freud Misinterpret Reported Memories of Sexual Abuse as Fantasies? 77 Psychol. Rep. 563-70 (1995); Jeffrey Moussaieff Masson, The Assault on Truth: Freud's Suppression of the Seduction Theory (New York: Farrar, Straus \& Giroux, 1984).

14 Judith Herman, Trauma and Recovery: The Aftermath of Violence (New York: HarperCollins, 1992).

15 Responding to the charge that he should have known it was wrong, an adult survivor said: "I was naïve. My mom and dad, you know, sex was a bad word. I was never taught. And I trusted the priest ... I wish I would've had some education, some 'this is right and this is wrong."' D'Antonio (2013), p. 105.

16 D'Antonio (2013), p. 19. 
17 D'Antonio (2013), pp. 207, 278.

18 See D'Antonio (2013), pp. 297-8.

19 See The Doyle-Moulton-Peterson Manual, May 15, 1985, in Thomas P. Doyle, A.W.R. Sipe \& Patrick J. Wall, Sex, Priests and Secret Codes: The Catholic Church's 2000Year Paper Trail of Sexual Abuse (Los Angeles: Volt Press, 2006), pp. 99-174; D’Antonio (2013), p. 151.

20 See D'Antonio (2013), p. 180; then Bishop Law referring to child molestation as a "hardship" suffered by the molested boys - see letter quoted later; monsignor on his understanding of why social worker had reported a priest in his care, "I suspected it had to do with acting out urges toward a boy." Id., p. 220.

21 D'Antonio (2013), pp. 122-3.

22 D'Antonio (2013), p. 180. Pope John Paul II made public comments along the same lines. In a letter written to Irish bishops following a meeting with them about priest abuse, the Pope referred to the "suffering of priests due to the pressures of the surrounding culture." Id. at p. 239. See also p. 293.

23 D’Antonio (2013), p. 138.

24 D'Antonio (2013), p. 44. In the Roman Catholic tradition priests are ordained by bishops who are in apostolic succession from St. Peter who was himself appointed to lead the church by Jesus Christ. In church doctrine they are the direct representatives of Christ on earth and therefore the only ones who can preside at communion, transforming bread and wine into the sacraments of the body and blood of Christ.

25 See Betrayal, p. 14; D’Antonio (2013), p. 118.

26 Betrayal, p. 125. In my view, plaintiffs' counsel also bear some responsibility for agreeing to confidentiality agreements that keep important public safety information secret.

27 The movie Spotlight (2015) provides a dramatic account of this process in Boston, Massachusetts.

28 Betrayal, p. 44.

29 Cardinal José Saraiva Martins, speaking to reporters of a conspiracy against the church: "We should not be too scandalized if some bishops knew about it but kept it secret. This is what happens in every family. You don't wash your dirty laundry in public." D’Antonio (2013), p. 326.

30 In the Catholic Church, bishops are chosen from the ranks of priests; as bishops they retain all their priestly powers and obligations, to which are added new powers and responsibilities as a bishop.

31 Part of the ordination vows for a priest is one not to bring scandal to the church, which some have argued supports efforts to handle abuse allegations internally.

32 So, for example, Monsignor John Anthony Oliver testified that he forwarded a report on a local priest's abuse of children to his bishop, but did not question the priest himself. "It's not my responsibility to hear those things. Personally, I don't care to know those things unless I have to." Betrayal, at p. 76.

33 See Laurie Goodstein, He Forced the Vatican to Investigate Sex Abuse. Now He's Meeting with Pope Francis, The New York Times, April 24, 2018; Alexandra Zavis, Abuse Survivor Quits Pope's Child-protection Panel, Citing Lack of Cooperation in the Vatican, Los Angeles Times, March 1, 2017. 
34 D'Antonio (2013), p. 248.

35 D'Antonio (2013), p. 14.

36 Betrayal, pp. 107-8.

37 D’Antonio (2013), p. 151, quoting Cincinnati Archbishop Daniel Pilarczyk.

38 D'Antonio (2013), pp. 225-6. Note that even here, the alternative to a pastoral response was medical treatment, not moral or legal responsibility.

39 D'Antonio (2013), p. 34. The contrast between the treatment of priestly sins and the church's moral and spiritual condemnation of sins by nonclergy was particularly striking to many lay Catholics. "I remember in the 1950s if you ate meat on Friday, did not wear a hat or veil to church, or ate breakfast before Communion, you could burn in hell for the sins. How come there is no mention of Geoghan going to hell?" asked Catholic layman Victor Conlogue, referring to the priest abuser John J. Geoghan. Betrayal, p. 185.

40 Betrayal, p. 214. The reference to a period of observation under Massachusetts law is a reminder that the criminal justice system often treated sexual child abuse as more of a medical problem than a criminal one at the time.

41 Betrayal, p. 31.

42 Betrayal, p. 217.

43 In the New Testament, parables of recovering the one lost sheep, which illustrate God's love for wayward humankind, may be found in the books of Luke and Matthew. Luke 15: 3-7; Matt. 18: 10-14.

44 Betrayal, p. 24.

45 Betrayal, p. 105.

46 Betrayal, p. 161.

47 Frank Baumgartner \& Tim Lyman, Race-Of-Victim Discrepancies in Homicides and Executions, Louisiana 1976-2015, 17 Loy. J. Pub. Int. L. 129 (2015). American Bar Association, Evaluating Fairness and Accuracy in State Death Penalty Systems: The Georgia Death Penalty Assessment Report, p. iv. January, 2006. The Sentencing Project, Policy Brief: Racial Disparities in Youth Commitments and Arrests, April, 2016, found at sentencingproject.org. Michael Winerip, Michael Schwirtz \& Robert Gebeloff, For Blacks Facing Parole in New York State, Signs of a Broken System, The New York Times, Dec. 4, 2016. Similar race issues appear in New York's prisons in the disciplinary process: Michael Winerip, Michael Schwirtz \& Robert Gebeloff, The Scourge of Racial Bias in New York State's Prisons, The New York Times, Dec. 3, 2016. New Jersey Attorney General, Interim Report of the State Police Review Team Regarding Allegations of Racial Profiling, April 20, 1999, found at http://www.state. nj.us/lps/intm_419.pdf. US Dept. of Justice, Office of Civil Rights, Investigation of Ferguson Police Department, March 25, 2015; US Dept. of Justice, Office of Civil Rights, Investigation of the Baltimore City Police Department, August 10, 2016.

48 Mapp, 367 U.S. 643 (1961); Miranda, 384 U.S. 436 (1966); Duncan, 391 U.S. 145 (1968). By contrast, in Furman v. Georgia, 408 U.S. 238 (1972), in which the Court overturned all existing death penalty laws in the United States, concerns about race discrimination were expressed by a number of justices in the majority.

49476 U.S. 79 (1986). This rule was extended to defense attorneys in criminal cases in Georgia v. McCollum, 505 U.S. 42 (1992). 
50 Johnson v. California, 543 U.S. 499 (2005).

51 Pena-Rodriguez v. Colorado, 137 S.Ct. 855 (2017).

52 Buck v. Davis, 137 S.Ct. 759 (2017).

53137 S.Ct. at 777.

54 Whren v. U.S., 517 U.S. 806 (1996).

55 U.S. v. Armstrong, 517 U.S. 45 (1996).

56 Amina Khan, Science File: Black Men's Plight as "Superhuman": Bias that Minority Males are Bigger, More Menacing than White Men May Play Role in Police Shootings, Los Angeles Times, March 15, 2017. There is strong evidence that African American boys are seen as older and less innocent than other boys of the same age. Phillip Atiba Goff \& Matthew Christian Jackson, et al., The Essence of Innocence: Consequences of Dehumanizing Black Children, 106 J. Personal. \& Soc. Psychol. 526 (2014).

57 People v. Goetz, 68 N.Y.2d 96, 497 N.E.2d, 41 (1986); George P. Fletcher, A Crime of Self-Defense: Bernhard Goetz and the Law on Trial (Chicago: Univ. of Chicago, 1988).

5868 N.Y.2d at 102, 101. 


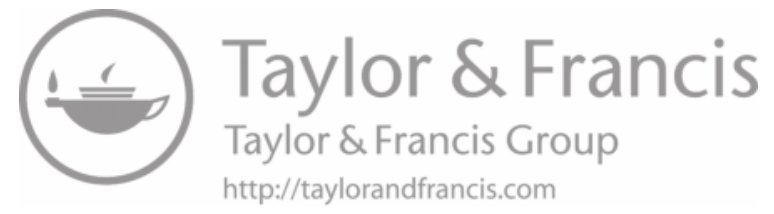


PART TWO

Just Punishment 


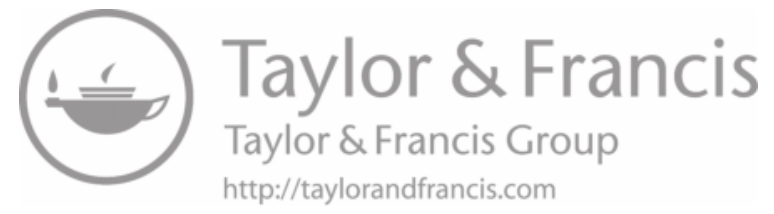




\section{INTRODUCTION TO PART TWO}

Punishment is the great preoccupation of contemporary criminal lawyers in the United States. While questions of guilt certainly matter, on a day to day basis prosecutors and defense attorneys and judges in criminal court devote most of their energy to anticipating and resolving questions of punishment. Pretrial dismissals of charges occur, but not that often. Trials occur, but unlike on television or the movies, they are exceptional events in all but the most serious cases. The great majority of cases are resolved by plea bargains, in which much of the bargaining concerns punishment. Most cases end with the judge's punishment decision, meaning the defendant's sentence.

Punishment presents the great moral question of criminal justice. How can punishment, which is the deliberate infliction of suffering on another, be justified? How can it be justified in those (many) cases where the defendant has already suffered enormous personal and social disadvantage? If some punishment is merited, how much? And what will that mean in reality? Can the reality be justified?

How we punish is one of the most distinctive features of American criminal justice today. Our enthusiasm for incarceration has drawn widespread international and domestic criticism. But it is not just the numbers imprisoned, but who is imprisoned, and our attitude towards them that need close examination. Can current punishment practices in America really be justified?

In Chapter 4, we look at basic principles of just punishment. In Chapter 5, we look at changes in modern sentencing for violent offenses, with a focus on California's experience in passing and implementing mandatory life penalties for certain crimes. In Chapter 6, we look at the reality of incarceration in America, considering in particular the prevalence of sexual violence and the use of solitary confinement. 


\section{4}

\section{PUNISHING WITH REGARD}

Excessive bail shall not be required, nor excessive fines imposed, nor cruel and unusual punishments inflicted.

Eighth Amendment, US Constitution

Perhaps it is good that, when we recommend punishment, we should always feel conflicted and slightly unclean about what we are doing. This might at least blunt our tendencies toward cruelty.

Legal philosopher Jeffrie Murphy ${ }^{1}$

I am conflicted about criminal punishment. I think we should all be conflicted about criminal punishment. There is a kind of violence in the decision to deliberately inflict long-term suffering on another. How can that be good? And yet without painful public consequences for wrongdoing-meaning punishmentdeclarations of personal responsibility lose much of their force.

Apologies and evidence of personal reform, expressions of forgiveness and processes of reconciliation have their place in a scheme of justice, as we will see, but none can meet the modern community's need for a forceful, collective answer to the worst acts of violence. Serious wrongdoers need to be punished. Without significant punishment, the community's commitment to those hurt and to the value of nonviolence will be suspect. A critical aspect of public justice will be missing.

Even if serious punishment is justified, though, the authority to punish can be abused. The US Constitution condemns cruel punishments-whatever they are. Deciding what is cruel is hard, given that punishment entails painful consequences designed to answer often cruel deeds. 
Parents know how hard punishment decisions can be. Trying to decide whether to punish - and how - a whining three-year-old who refuses to hold a parental hand when crossing a busy street, or a 13-year-old caught drinking or using drugs, will tax mind and spirit. Punish in anger and you will likely regret it with both heart and head. Neglect to impose a significant sanction and the dangerous behavior may persist, even worsen. Punishing strangers for criminal wrongs is even harder because we have no personal reason to care about them and the wrongdoing involved is usually more serious.

Punishment decisions in criminal justice are hard, but to be precise, criminal punishment is hard to get right. Just punishment is hard. Punishing unjustly-not so much. We do that all the time.

This chapter is about the challenges of punishing in accord with the principle of moral regard: regard for victims and offenders alike. This is hard, but not impossible. We will look at the sentencing decisions of courtroom judges and also the sentencing directions given them by the public. Judges decide sentences in particular cases; the public, through its representatives, sets sentencing policy. Each have their own responsibility for just punishment in America.

\section{Punishment and Incarceration}

Punishment for crime is something the state does. Only the government can impose punishment. In the United States, the government punishes in the name of the people. Thus in my home state of California, state criminal cases are titled, The People of California v. [full name of the defendant]. In federal court they are The United States of America v. [name of defendant]. While actual punishment decisions may be made by legislators, prosecutors and judges, they act in our name. Acquiescence to professional authority does not release us from responsibility for punishment done on our authority, with our tax money.

Punishment must be authorized by law. Criminal charges can bring public shame and private guilt, and do great harms to family and reputation, but these do not count as punishment because they are not legally ordered sanctions for a criminal offense.

Punishment entails pain. The punished person suffers punishment. Punishment is designed to impinge on the good in life. It may deprive a person of time and liberty, of property, of relationships, of chosen work. It should be a painful consequence that most want to avoid. Judges may include in their sentences a mandate for rehabilitative programs such as drug and alcohol treatment, and preventive provisions, such as stay away orders, but what we are concerned with here is the part of punishment designed to cause pain. This is what makes it morally challenging. 


\section{The Punishment of Incarceration}

In this chapter and throughout this book I am primarily concerned with punishment by incarceration. Such punishment brings great pain.

We normally associate pain with physical hurt. As a result, there is a tendency to believe that painful punishments are a feature of the past. We no longer whip convicts as punishment, no longer brand their faces or hands or mutilate their ears, no longer combine capital punishment with physical tortures such as being drawn and quartered. All these were part of the English criminal law that Americans in their new republic rejected in the late 18th and early 19th centuries. The American creation of the penitentiary during this period, which was one of the republic's most celebrated public policy innovations, came in response to the need for effective criminal punishment that was not physically brutal. ${ }^{2}$ And yet American incarceration has always inflicted great pain. That is by design. It's just that the hurt is more to the spirit than the body.

The pain of incarceration begins with the prisoner's loss of freedom. It is no coincidence that the founders of a nation dedicated to the protection of liberty decided that the most appropriate, the most republican form of punishment was to deprive offenders of their freedom. The prisoner in the US generally cannot choose what to wear, when to eat or what to eat, or where to sleep. There are restrictions on what can be read, what can be viewed, how communications can be made. The restrictions on liberty go on and on.

Less obvious, but equally profound is the relational pain that comes from incarceration. Being sent to a carceral institution separates the prisoner from loved ones, from friends, colleagues and community. In the original American iteration of the penitentiary, this separation was a critical design feature. Today, separation is made worse because of locating many prisons far from urban centers, along with many visitation restrictions imposed for security and staffing reasons.

Incarceration severely restricts what the prisoner can do for others, closing an important avenue of meaning-making. Especially for young prisoners, incarceration can stunt personal growth by precluding relational development. Prisoners cannot fulfill commitments to intimate partners or to children. They cannot care for aging parents or grandparents. Life in community passes them by. To give but one illustration, one of the greatest losses that long-term prisoners can suffer is not being able to attend the funeral of a parent or a sibling and mourn the loss with family.

By design, incarceration means social exclusion. Being sent to prison signals that, at least for a time, the person does not belong in society. The American prisoner is constantly reminded of this fact by all the circumstances of his or her daily life. We have already seen that belonging is one of our deepest human needs. Living locked 
up means living in exile. Even after release from confinement, the legal and economic disabilities that flow from conviction and imprisonment mean that the offender's state of not-belonging may persist, indeed may be permanent.

From the law's perspective, the pain suffered by family members because of their forcible separation from a loved one is an unfortunate side effect of incarceration. This is more than just collateral damage, however. The relational loss suffered by those connected to the inmate is inherent in this penalty. As the prison saying goes: you do the crime, but your family does the time. Children grow up without fathers or in some cases, mothers. Brothers and sisters grow up without siblings. Marriages and other intimate relationships are strained and often break because of the distance imposed by incarceration. Because these costs are inherent in incarceration, and are particularly severe in American penal practice, they should be part of the moral burden carried by the punisher.

Given these costs, the question is whether incarceration can be justified at all.

\section{Justifying Punishment, Justifying Incarceration}

Why must we punish to hold wrongdoers responsible? Why not put aside this dark and ancient idea of painful payback for crime and focus on ways to remedy wrongs? What if we directed criminal justice resources to offender rehabilitation and reform? What if we increased compensation for victims and took concrete measures to address their emotional pain and economic losses rather than try to assuage them with another's suffering? Why the need to inflict personal pain on the offender as punishment? Isn't responsibility for the past crime essentially complete with conviction?

The answer takes us back to Chapter 2 and the purpose of criminal responsibility. We judge persons criminally responsible to attach consequences to wrongdoing. Liability and punishment represent society's judgment about what the defendant did. As in: you committed murder, a serious wrong that merits serious punishment. You committed child abuse, a serious wrong that merits significant punishment. Responsibility judgments-both conviction and punishment-represent formal collective judgments on wrongdoing.

Another way to explain this distinction is by pointing to modern changes in how we see certain crimes. Take drunk driving. When I was young, driving under the influence was a criminal offense, but standards for impaired driving were much more lenient and so were punishments. It was common for serious drinkers to have a string of drunk driving convictions without serving more than a night or two in jail. A social campaign to change the public's understanding of the harms of drunk driving, spearheaded by Mothers Against Drunk Driving, had a major effect on 
both legal definitions of the offense and its punishment. States instituted new blood-alcohol standards and imposed more significant punishment. A first offense DUI (driving under the influence) may not result in a jail sentence, but a second offense usually will. It may be mandatory. ${ }^{3}$

Could the shift in the public view of drunk driving, to make it a much more significant wrong than in the past, have occurred without any increase in its punishment? It is conceivable, but unlikely. Going to jail for the offense made real society's change of heart here. Jail sentences (and sometimes prison terms) embodied, made physical, society's judgment of dangerousness and wrongdoing.

With respect to violent offenses, recall the lack of punishment in the clergy abuse scandal discussed in Chapter 3. Or consider the outcry in many cases of lenient punishment for young men who commit sexual assault. I do not think we can make clear the moral and social unacceptability of serious crimes without punishing their perpetrators.

Punishment should never be our only response to wrongful violence. Later chapters will make this clear. Also, while incarceration may be ordered as punishment, its daily experience should not be punitive. The loss of liberty is sufficient to accomplish its essential penal purpose. Incarceration can and should provide opportunities for education, healing, reflection, skill-building and change.

Nor should we be satisfied with justifying punishment in principle. We must always consider its reality. Who actually receives this penalty? What is their actual experience? Critics of American criminal justice today point to a whole range of inefficiencies and injustices in incarceration. Race and class discrimination seem almost inherent in the enormous expansion of jail and prison populations that has been called mass incarceration. Connections between present punishment and past practices of slavery and segregation suggest that a practice presented as lawful punishment may be used to accomplish social, racial and economic oppression. ${ }^{4}$ I will take up some of these questions later in the chapter. Conditions of confinement will be the particular concern of Chapter 6 .

For now I want to look at how a sentence of incarceration might be justified. To this end, consider a case of armed robbery.

\section{Armed Robbery: A Crime of Disregard}

Imagine the following. ${ }^{5}$ On a cold rainy night in November, Sandra Pettit is working alone as a clerk at a 24-hour convenience store. Sixty-seven years old, only an hour into her shift her feet already ache from standing on the hard tile floor. She hates being away from her husband who is struggling with diabetes. Medical bills and rising heating costs mean that they need extra income though, and the convenience store job is 
the best she could find. She is working the night shift because 19-year-old Jerry, who was assigned it, called in sick 90 minutes before he was due to start. At least he said he was sick. Because it's Friday night, and he has a habit of calling in sick at the last minute, Sandra has her doubts.

At 11:37 pm, a man probably in his 20 s enters the store. He is wearing a blue windbreaker and baseball style cap with the logo of the local pro football team pulled down low. He heads for the back where the coffee is brewing. Sandra hears the distinctive whoosh and gurgle of coffee being dispensed into a cup. She looks outside at the rain streaming down the front window of the store. Suddenly the man appears before her, his coffee cup on the counter. He asks for a pack of cigarettes, naming the brand. She turns to get them from behind her. When she turns back, he has a gun pointed at her face and says: "Empty the register. Just the bills."

Sandra stands frozen in fear.

"Now-you old bitch!" the man yells, his voice raw with anger.

Sandra is startled into action. She takes the money from the cash register and pushes it across the counter to the man. He stuffs the bills into his jacket pockets. He gets a total of $\$ 183$. The man sticks the gun in his waistband and rushes out the door into the parking lot.

Sandra stands shaking. I could have been killed, she thinks. And for what? She triggers the silent alarm that will bring the police.

The criminal law calls this a robbery. The man with the gun appears to have committed the intentional, unlawful taking of the personal property of another by force or threat of force. He will likely be charged with armed robbery: a robbery accomplished by use of a deadly weapon - in this case, a gun. For a conviction, the state must prove each element of robbery. The prosecution will need to prove that the defendant intentionally took money (personal property) that belonged to the convenience store (of another) and did so by threats and use of a gun (threat of force).

For most people, news of an armed robbery like this will cause fear and concern; this is a scary, dangerous event. Hearing about the robber's later conviction and punishment (if it occurs) will reassure residents that basic law and order has been restored. Criminal law serves an important role in assuring basic safety. But it does more than that.

In a nation like the United States with diverse peoples, with different religious backgrounds and cultures and widely varying ideologies, the criminal law has a critical role in defining community. It expresses and defends base-line principles of right and wrong conduct. ${ }^{6}$ This is an essentially moral role, which explains why the impulse to convert moral outrage into criminal prohibition is so strong in the 
United States. The criminal law, as set out in statutes and court decisions, reflects norms about the kind of community we believe in and the kind of individual conduct that we demand of each other. It sets basic moral expectations, and thus moral principles, for community.

In his threatening words and actions, the robber told Sandra Pettit: give me what I want, or you will suffer deadly harm. He expressed a particular view of human relations, in which power trumps basic human value. The one with power can disregard the unique person and value of another in order to satisfy personal needs.

Now it is certainly possible, even likely, that the robber just wanted money and thought that a stick-up was the best, perhaps the only way that he could get it. He may not have thought anything about power trumping individual value when he decided to rob the store. ${ }^{7}$ But as discussed in Chapter 2, we blame wrongdoers not just for what they intend, but also for the moral attitude that their acts convey. The act of robbery demonstrates disregard for basic community norms of property ownership and nonviolence.

\section{Distinguishing Conviction and Punishment}

When I teach criminal law, I spend a lot of time helping students distinguish the legally relevant from the irrelevant. A basic skill of the American lawyer (one that nonlawyers tend to find impressive or obnoxious depending on where they stand in the controversy) is to ruthlessly exclude considerations that the law deems unimportant, no matter their importance in other contexts. For example, in our armed robbery case, to secure a conviction the prosecution must prove that the defendant used a deadly weapon in the form of a firearm. But what is a firearm? Under the legal definition used in most jurisdictions, it will not matter whether the gun was loaded, or even if the gun worked. An unloaded gun is still a firearm under the law of armed robbery; so is a mechanically defective gun. The law's reasoning here is that armed robbery is about the threatening use of what appears to be a deadly weapon to obtain personal property. The victim normally does not know whether the gun is loaded or works, but will assume the worst. From the victim's perspective, it is still an armed robbery.

To give another example of the criminal law's limited focus, many people looking at this case of robbery would want to know the defendant's motive. For example, did he rob the store to get money to feed a hungry child, or to feed his own drug habit? For purposes of determining guilt, motive is irrelevant. Guilt turns on why the alleged robber spoke and acted as he did. Did he threaten force to get money from the till? Why he felt the need to get money in such a desperate manner does not matter-to guilt. 
The interests of the law expand when we move from guilt to punishment, however. At sentencing, the judge would likely want to know the defendant's motivation for the offense. Robbing for family reasons versus drug use might change the judge's view of the severity of the offense and the dangers presented by the defendant. Whether the gun was functional and loaded could also change the sentencer's view of the case.

In most jurisdictions, for felony sentencing judges receive what are called presentence reports (or PSRs) that provide the basic facts relevant to sentencing. The following might be a typical summary of a PSR in the (fictional) robbery of the convenience store case.

Thomas Tyrus Daley, was convicted of armed robbery on February 11 of this year in Superior Court by means of a guilty plea. He is a 22 -year-old male, currently in custody in the county jail. He states that he was a well-adjusted kid, successful in school, one of three children raised by his single mother. Then in sixth grade his mother died of breast cancer. He says this is when his life "went to hell." Subsequently he was placed in several relatives' homes, and for a brief time in a foster home, where he claims he was physically abused. He dropped out of school at age 16 and has been on his own since then.

Daley began regular use of alcohol when he was 12 years old. By the time he left school he was addicted to methamphetamine (crystal meth). He has also huffed (used aerosols for intoxicating purposes), smoked marijuana regularly, and on several occasions used cocaine. Two years ago he was treated for depression.

Daley has worked in various part-time jobs, primarily related to transportation (deliveries). He was adjudicated a ward of the court (convicted) of business burglary in juvenile court when he was 17 . He has two arrests as an adult for physical altercations that did not result in convictions.

Daley denies involvement in any other robberies or other offenses, saying that the present offense was a spur of the moment decision on his part, in reaction to hearing that his girlfriend was breaking up with him and would not let him see his two-year-old son. Daley states that the gun he used was lent to him by a friend, and that he threw it into the river afterwards. However, the detective on the case states that he believes Daley was responsible for at least three city robberies prior to this one, based on location, modus operandi (MO), suspect description and the fact that the robberies stopped following Daley's arrest. The detective notes that the way the robbery was carried out suggests that the robber had done it before.

Daley expresses remorse for his offense, but states that he never wanted to hurt anyone, that the gun was unloaded, and denies saying anything to the store clerk except that he wanted the money from the cash register. He says that he knows that 
he has a drug problem and is ready to do any program ordered by the court. He hopes though that he will not have to do prison time because he needs to be there for his son.

What should Daley's sentence be? To make this decision, the judge will have number of tough calls to make.

Where the facts are contested, the sentencing judge must decide who to believe. Is Sandra's account of the robbery accurate, particularly the "you old bitch" statement she recounts, or is Daley's account as given in the PSR likely correct? Did Daley commit other robberies? Even more challenging are the many normative judgment calls that the sentencer must make.

Initially the judge might want to decide on a philosophy of punishment. The main contenders in this field today are retribution and deterrence. ${ }^{8}$ Retribution holds that punishment should be meted out in proportion to the defendant's proven wrongdoing. It assesses the defendant's blameworthiness for the offense, considering his mental state (purposeful, knowing, or reckless, usually) and its intended or predictable consequences with respect to harm done or threatened. The idea is that a defendant deserves punishment according to the relative badness of what he did, regardless of punishment's effects on future behavior. So, for example, a court might sentence a defendant to a long prison term for murder even though the defendant is elderly, has no criminal record and it's clear that he will not offend again. Following retributive principles, murder is murder; the defendant deserves serious punishment because he committed a serious crime.

Under deterrence, punishment is assessed according to what is needed to deter future crimes by the defendant and others. A utilitarian calculus is used: the right punishment is that which produces the greatest good for the greatest number. Utilitarians often correlate good with happiness or pleasure, and bad with unhappiness or pain. Since punishment involves inflicting pain, which is bad, it should be used only if - and to the extent that - it produces a greater good (happiness) in deterring future crimes. The greater the harm that a crime does, the more benefit is produced in deterring its future occurrence; conversely, the more minor the offense, the less justification there is for significant punishment. Because shoplifting a dress causes less social harm than setting fire to an occupied building, deterrence would say that punishment for the shoplifting should be less than that for the arson.

Under deterrence, the defendant's future dangerousness is an important consideration. A young gang member who played a small part in a crime committed with others might not deserve much punishment under retribution, but if he appears likely to commit future serious offenses with the gang, deterrence would support significant punishment. 
Retribution and deterrence provide important guidelines for sentencing, but because they are very general, they may be applied very differently by different sentencers. Complicating matters further is that most judges do not have a singular philosophy of punishment. Most judges consider retribution and deterrence according to what seems to make sense (to them) in the case at hand.

At sentencing, the judge evaluates both offense and offender. The latter effort raises many difficult questions. Returning to our robbery case, the defense may emphasize defendant Daley's family history in seeking a lighter sentence. The defense will tell the story of a young man devastated in youth by his mother's untimely death. Substance abuse, depression, and victimization in a foster home followed. All this puts his current offense in context. His crime appears much more the result of long-standing trauma and depression than the act of an essentially malevolent person. He's not as bad, or as dangerous, as he might otherwise seem.

The prosecution is unlikely to be moved. Everyone has a story, may be the prosecutorial retort. Personal history does not change what he did to Sandra Pettit or what he deserves. As for dangerousness, his unfortunate history might actually make him more likely to offend again.

There are many more issues to consider with the offender's background. Take Daley's prior juvenile record. Does this show him to be more dangerous than someone without a prior record? More deserving of punishment than someone without a criminal history? And what about his history of substance abuse? Do his substance abuse problems make him more or less dangerous? More or less deserving of punishment? What about his statement of remorse? If the judge is not convinced that Daley is taking full responsibility for his actions, how should that affect the sentence under retribution or deterrence?

Even if the judge's sentencing decision in this case is couched in terms of public safety (deterrence) or what the defendant deserves for his crime (retribution), the sentencer's decision process is likely to begin with an intuitive sense of what might be right. Which is another way of saying-though few judges would admit this - that their judgment begins as an emotional response to the case. This means that to ensure just decisions, we need a norm that addresses sentencer emotions. The need for emotional regulation becomes especially acute when we realized that many critical punishment positions are made by voters and their elected representatives. Legislators set the parameters of punishment through statutes; prosecutors, generally answerable to an elected head of office, have extensive authority over the application of punishment laws through charging and plea decisions. 
Bottom line: in determining just punishment, a sentencer's mind often follows the heart. Which means we need a guide for sentencing that is emotionally savvylike moral regard.

Before we apply the regard principle to the sentencing of individual offenders, though, we need to widen our justice perspective to consider the general fairness of punishment in America today. We need to consider the fairness of punishing offenders who have been shaped by a very unfair world. Answering this challenge will make clear what justice in punishment means, and even more importantly, what it does not.

\section{A Reality Check: Just Punishment and Social Injustice}

The discussion of punishment so far has assumed that defendant Daley freely chose to rob Sandra Pettit. We assume that, just like you or me, he was free to choose between right and wrong. We can imagine situations where that would not be true, of course. Someone who was forced at gun point to commit a crime would not be free to choose. But without evidence of some sort of gun-to-the-head type coercion, we assume that all rational adults in America have the same basic freedom to obey or to violate the law. But is this true?

Anyone familiar with the realities of criminal justice today (and frankly at just about any time in the past as well) knows that those who commit crimes come disproportionately from the ranks of the most disadvantaged. Equal opportunity is not a phrase that springs to mind when we look at the lives of the punished. Or at the working of the legal system.

The inequalities of American society are reflected in how the criminal justice system operates; the inequities of society are also vividly illustrated in the lives of those convicted and punished. Which raises an important question. How is just punishment possible when punishment reflects and may perpetuate social inequity?

\section{Due Process: Promise and Reality}

The courthouse is one of the few places in America where people of all backgrounds must interact. The rich and the poor and everyone in between may be summoned to court, or go there to seek justice. People of all races and backgrounds interact as litigants, witnesses, defendants, jurors. The courthouse is where justice for all is done.

Justice for all. A grand ideal, meaning what exactly? At a minimum, it means that the same rules should apply to all. It means that every person should have an equal chance to contest criminal charges brought against them. Every person is 
guaranteed a right to due process of law prior to any deprivation of life, liberty or property under the US Constitution. To be clear: every person has the same right to due process. In fact, money, education, race and social status can determine how much process an accused receives.

One of the centerpieces of American due process, and indeed democracy, is the constitutional right to a jury trial. ${ }^{9}$ Yet the great majority of criminal cases in the United States are resolved by guilty pleas, not trials. This is absolutely vital to the functioning of the contemporary criminal justice system. In most jurisdictions, if even a significant minority of defendants - say 20 percent, maybe even 10 percent-insisted on trials, the legal system would collapse for lack of judges, courtrooms and court personnel, prosecutors, defenders, and jurors. The resource reality is that for the great case processing machinery of contemporary justice to keep grinding on, the great majority of criminal cases must be resolved either by pretrial motions or the defendant must plead guilty. Mostly, defendants plead guilty.

The modern American legal system has found numerous ways to encourage, some would say coerce, defendants to plead guilty. These methods exert considerably more pressure on disadvantaged citizens than on the advantaged. The unfairness involved is often invisible to the outside world because, in the end, defendants apparently choose to plead guilty. They "voluntarily and intelligently" waive their constitutional rights in open court, almost always with the advice of counsel. They would not do that without good reason, right?

In many cases, defendants do have sound reasons for pleading guilty. Their guilt is obvious, meaning they have no good reason to go to trial, meaning that receiving a sentence discount for pleading guilty is actually a good deal for them. Indeed it may be a win-win resolution of the case, as the prosecution receives a certain and relatively inexpensive conviction followed by punishment, in return for giving up the possibility of winning a longer sentence for the defendant following a trial conviction. There are many cases, though, where defendants do not believe themselves guilty and consider the prosecution's case to be highly suspect and therefore would very much like to go to trial. Yet systemic inequities cause them to plead guilty.

On paper, defendants have an impressive package of constitutional rights that they may assert. The judge will inform the defendant of his or her right to confront accusers, to compulsory service of process to bring witnesses to testify and to have a jury of fellow citizens determine his or her guilt at trial. In reality, the cost of exercising these rights makes them unaffordable for many.

In many cases, whether the defendant can secure release from jail pending trial can make all the difference to having a trial. Defendants who cannot make bail because they are indigent, because they are charged with a probation or parole violation or 
for other reasons, face much greater pressures to plead guilty. Staying in jail for even a week or two may mean losing a job, a relationship, a place to live. With a guilty plea, the defendant may be released immediately, or with only a short further stay in custody. Especially in misdemeanor cases, it's not uncommon for defendants to be told that they will spend more time in jail if they go to trial and are acquitted, than if they plead guilty now. Then comes the legal disclaimer: But of course it's your choice. You have the right to a jury trial.

Some defendants plead guilty because their appointed counsel lack the resources to mount an effective defense. For example, appointed counsel often have no time and money for independent fact investigation. Defense attorneys must evaluate the strength of the prosecution's case based primarily on police reports-the same reports that prosecutors used to determine whether charges should be filed. Defense attorneys will also hear their clients' accounts of events, but they know that jurors will often treat testimony from the defendant and his or her friends, associates and family skeptically. In a straight credibility contest between defendant and police officer, the police officer wins, nine times out of ten. Many indigent defendants have prior criminal convictions that persons with better representation in the previous cases would have avoided. This criminal history may make it nearly impossible to effectively contest the present charges because of the chance that it will come out if the defendant testifies. Once the jury hears about the prior conviction, it will be much more likely to believe the defendant is guilty of present charges, regardless of present facts.

In some cases, harsh statutory penalties give prosecutors enormous bargaining power over the defense. If a mandatory minimum penalty of fifteen years applies to a charge, prosecutors can promise that 15 years will be the minimum sentence following a trial conviction, but can offer, through a reduction of charges, that the defendant will get no more than seven years following a guilty plea. Under these circumstances, many defendants, advised by counsel, will decide they cannot risk the longer sentence that would follow a trial conviction, so they plead guilty. ${ }^{10}$ Even defendants who know they are innocent of the charges brought against them sometimes plead guilty because of the disparity between the sentence promised (following a guilty plea) and the sentence threatened (following a trial conviction). These are just some of the standard inequities of contemporary criminal practice, inequities that mirror those of the society at large.

\section{Social Disadvantage and Criminality}

Prior to announcing sentence, the judge will ask the defendant if she or he wants to be heard. Defendants have the right to what is called allocution, to address the 
court on the subject of sentence prior to the decision. Sometimes the defendant will respond with a basic plea for leniency or will offer an apology for his or her hurtful conduct. If the defendant speaks, he or she does not usually speak for long or with much force, however. Many times the defendant will decline to speak, leaving only the defense attorney to advocate for the defendant. From a middleclass white perspective, the lack of vigorous self-advocacy by defendants at sentencing is surprising. Wouldn't anyone facing serious punishment have something important to say on their own behalf to the judge? But most defendants have a different expectation of authority than white middle-class folks do.

They do not expect to get a break. They never have before. They do not expect to be truly heard. They haven't been before. They expect the worst, because that is standard for them. In this sense, even if never convicted before, the experience of sentencing is not new. It has a terribly familiar feel to it.

The defendants who appear for sentencing in America today are largely the most disadvantaged in society. Disproportionately they come from the lowest economic strata. They have suffered the worst educational disadvantages in schools. They are disproportionately people of color, black and brown. Their race makes them suspicious persons in the eyes of police and others, which leads to more extensive criminal records for even minor offenses which cumulates their social disadvantages. They come from groups with the worst health and worst access to quality health care. They have the shortest life expectancies.

The connection between social and economic disadvantage and criminality has been recognized for centuries. Nor does the connection require any great effort to explain. Those who have not lack the same incentives to law obedience as those who have. Those who do not belong are more inclined to see the law as designed for their disadvantage rather than for the mutual advantage of all. The poor have few choices, and even fewer good ones. In communities with sparse legitimate work, black market endeavors may be the only realistic option for supporting self and family.

But my focus remains on criminal violence, not with the general run of drug and property crime. What does all this disadvantage have to do with violence? The more highly stressed the community, the more that members must compete with each other for the few social and economic resources available. Are we really surprised that the resulting competition for opportunity and respect between men, and sometimes between women, often turns violent? It is utterly predictable.

The point is that the socially disadvantaged are very differently situated with respect to the criminal law than the advantaged. Staying straight is harder for the former than the latter. 


\section{Criminal Violence and Childhood Trauma}

Finally there is the unfairness of childhood trauma. Such trauma may be the single greatest contributor to later violence. And it is definitely not chosen.

Poverty and discrimination matter but generally do not lead to criminal violence if children grow up in a stable and caring family. Young people who are raised in a home that is physically and emotionally secure, with consistent attention and love from parents or guardians are likely to avoid serious involvement with the criminal justice system. By contrast, most who commit criminal violence have had caretakers who, at least for important times in their youth, did not provide the support and guidance that children need. Perhaps this was because of a parental struggle with substance abuse or mental illness. Many who subsequently commit violence grew up in chaotic and even violent homes, where affection was uncertain and may have taken twisted forms. Purely economic causes can lead to significant deficits in caretaking. Some offenders lacked for a parental presence when they were young because they grew up in a single-parent household where the parent had to work multiple jobs to keep the family in food, clothing and shelter. Or, everything may have changed for a child with the death of a parent, grandparent or other guardian.

The man who appears for sentencing for murder today may appear a hardened tough guy, but he was once a six-year-old boy given crack cocaine for the first time by his own parents. The defendant convicted of a violent crime last month was once a boy raped by a mother's boyfriend, who went days without seeing a sober adult in the house, who lived on refried beans scraped from a can and stale potato chips. He grew up never knowing who would be at home and whether, as a result, he would be safe. Growing up in foster care, or living on the streets, may be important contributors to criminality for the same reasons.

In exploring the effects of childhood trauma we can get fixated on the most dramatic instances of physical mistreatment of children because these have the greatest emotional impact on us. In recent years, however, the impact of less dramatic mistreatment in the form of parental inconsistency, neglect and absence has become clear. Just the lack of stable and caring guardians can make an enormous difference. For boys especially, the absence of a father correlates strongly with future problems, including criminal violence. ${ }^{11}$

\section{Implications for Just Punishment}

I remember the day I received my life sentence. I was in so much shock. Then I was filled with so much anger. I blamed everyone and everything. I excused the crimes I committed because "I was the victim of life." "Life" had not been fair to me. ${ }^{12}$ 
The question is what do we do with this evidence of discrimination, disadvantage and trauma? What are its implications for justice in punishment?

The justice implications of discrimination in the legal system are relatively straightforward. We must do all we can to eliminate basic inequity in due process. There should be no economic discrimination in the availability of pretrial release from jail. Appointed counsel should have adequate time and investigative resources to provide adequate representation. Large disparities between threatened and promised sentences in plea bargaining should be reduced to minimize the chance of innocent people pleading guilty. And always, the right to a jury trial should be treated as a real world right, and not the cynical promise that it so often appears to be for many defendants.

Given that the due process problems I have described have been known for many years, and have resisted remedy in most jurisdictions, improvement is likely to be gradual. In the meantime, the legal system will be very reluctant to grant individual defendants relief. The problem is not that defendant claims of economic and other discrimination are unworthy, in fact it's the opposite. The problem is that too many defendants can make the same claims. And the system is not about to accept an argument that could hinder its basic functioning and undermine its claim to public respect.

The implications of disadvantage and trauma for punishment require a different discussion. Let's begin with the argument against taking these factors into account. Look at all the people who had things tough growing up. All the folks who grew up poor, went to lousy schools, and suffered discrimination. Look at all the people who had alcoholic parents or got knocked around as a kid. Did most of them commit serious violent crimes? No. The argument is that even in the most stressed communities, most who had rotten childhoods do not grow up to commit murder or rape or rob. This means that those who choose to commit violent crime-emphasis here on the word chooseshould be held responsible regardless of their bad luck in the social and family lottery. They may have been dealt a bad hand, but they still had the choice of how to play it.

My initial response is that this argument denies relational reality. Who we are depends on our relations with others, chosen and unchosen. Each of us is affected by social circumstances and family, both unchosen. Nor does this argument consider the complexity and variability of individuals. Trauma that may devastate one child, another may shrug off, because they are different people. Witness how differently children who are raised in the same home, with the same parents, and in the same community, turn out.

And yet, in the end, I also resist the idea that we should reduce punishment just because of histories of disadvantage or trauma. If we reduced punishment according 
to histories of disadvantage, certain defendants would be punished less than others despite committing crimes of equal severity. It is very likely this would lessen punishment for serious crimes in those communities that already suffer the most from criminal violence, because these communities are where the most disadvantaged live and a disproportionate amount of violent crime occurs.

Similar problems arise when we consider reducing punishment because of childhood trauma. The person abused or neglected as a child may never have had much chance to develop good moral character. Punishing this defendant as if he had the same chances to develop morally as other people did may seem unfair. But reducing punishment because of childhood trauma would weaken the link between wrongful act and consequence. Without fully punishing the crime, how can we make clear its full wrong? The victim's pain does not change according to the perpetrator's personal history. Nor the cost to the community. Finally, reducing individual responsibility for a person almost inevitably leads to a reduction in respect and power for that person. What excuses from punishment also tends to diminish humanity.

And yet - and yet the defendant's life story remains vitally important. We need to hear it as part of deciding sentence. Hearing and considering it is critical to punishing with moral regard.

\section{How to Sentence with Moral Regard}

One of the more extraordinary scenes that happens in American public life occurs in the criminal courtroom. It happens with some regularity. A judge calls the case, the attorneys and the defendant appear, and legal arguments are made; the record is corrected as needed. In some instances victims will speak, or family members or other supporters of the victim. Family and supporters of the defendant may speak. The defendant may speak on her own behalf. The attorneys will argue for their respective positions. Finally the judge will ask the defendant to rise. The defendant and his attorney stand up to face the black-robed jurist who sits on the raised dais before them. And then the judge pronounces sentence.

Especially in a case where the crime is significant and the judge has discretion over the sentence, sentencing is a moment of high drama. So much turns on the judge's words. In her proclamation of penalty, concepts of moral and legal responsibility become reality for the defendant, his family, crime survivors, and community.

I have known judges who relish the chance to hand down harsh penalties. Confident in their moral and legal judgment of the defendant's wrongs, their sentencing remarks are designed to strike mortal fear into the hearts of miscreants both in the courtroom and out. I know other judges who dread handing down a severe sentence 
to the point of experiencing physical distress. Most judges approach sentencing with some degree of ambivalence, understanding its necessity but never fully comfortable with the idea of deliberately inflicting pain on another human being and on their families.

So how should judges decide on the right sentence? Most judges will be guided by principles of deterrence and retribution, in a process that I described earlier in the Daley case. These are important to a just decision. But now, I want to add the perspective of moral regard. This approach engages the judge on a more personal, meaning more emotional level. Like other important decisions, punishment decisions often arise out of intuitive, meaning emotional, assessments.

In a case of criminal violence, using the regard principle in sentencing means seeing the uniqueness of the victim and having concern for his or her good. This means doing what we did in Chapter 1: appreciating hurt to body and soul. The judge assesses how the offender's acts of disregard de-valued the victim and attacked her belonging in community.

In our robbery case, the judge would see that Thomas Daley not only robbed the convenience store; he terrorized Sandra Pettit. His words and actions demonstrated disregard for her as a person, as a woman (the bitch comment) and as an older, more physically vulnerable individual. He did not see her for who she was and certainly did not care about her basic well-being. He threatened her life.

The judge's sentence may show solidarity with Sandra Pettit by demonstrating the community's view of what happened to her. The sentence may communicate to her, the defendant and the community, that the defendant seriously wronged her. If a significant sentence of incarceration is given (and what "significant" means is a whole other discussion), the state will commit significant resources to punishment.

Justice in sentencing must also include moral regard for the defendant, though. The judge must make an effort to see Thomas Daley the man as well as the convicted robber. His upbringing, including the loss of his mother in childhood, his substance abuse history, his mental health status, these will be important for multiple purposes. They may help in assessing his present and future dangerousness and whether (and how) rehabilitative efforts such as substance abuse programs, mental health treatment or education might help him change.

Daley's life story should also remind the sentencer of his humanity and essential value. Without an effort to see him and to care for him as a person, it would be easy to condemn him as fundamentally bad, as a Criminal and not a person capable of good and bad.

This is what a commitment to moral regard in sentencing does. Obviously there is much that moral regard cannot do. It does not, by itself, dictate the proper sentence. 
How much time should defendant Daley do? Might he be given a probationary sentence under some circumstances? Five years, ten years, more? How much should parole and good time (time off for good behavior) rules figure in? Moral regard does not answer these questions directly, but in this it does not differ so much from principles of retribution or deterrence, which also provide only general guidance. What the regard principle does is help the conscientious sentencer avoid basic mistakes by missing basic considerations.

There is no question that sentencing becomes more difficult, morally and emotionally, when the sentencing authority follows the dictates of moral regard. Having moral regard for both victims and defendants means experiencing mixed emotions, meaning conflicting emotions. This condition risks moral and legal paralysis. Final answers become more difficult. And yet this is what moral regard requires. I believe it is what justice requires.

\section{Character Traits for Just Punishers: Confidence and Humility}

People sometimes ask me if I ever wanted to be a judge. I have had different answers over the years, but mostly I say that I never sought the bench because I'm not sure I could do the job. I lack the necessary moral confidence, particularly to sentence convicted defendants.

Judges need confidence to make hard calls and then move on. They cannot agonize about past decisions. This is essential to surviving, and thriving, as a judge. Meanwhile I agonize about giving students low grades in law school even when the grades are deserved and are essentially mandated by the school's grading rules. If I struggle with that, how could I sentence someone to a hefty prison term? Knowing this about myself, I respect judges who carry the weight of hard sentencing decisions in criminal cases.

In the sentencing of our robber, Thomas Daley, a judge would need moral confidence to consider seriously a painful sanction in the case. Such confidence would be based on an assessment of the severity of the wrong done to Sandra Pettit and concern for the community's safety. Yet a wise judge would also be humble enough to be wary of passing quick judgment on another human being. She would also look beyond the acts of a gun wielding man in the convenience store to see how Daley was shaped by his past, and how he might be different in the future.

This moral confidence-humility combination parallels the ideal of judicial temperament, which is much discussed in judicial appointments or elections. In presiding over our courts we want someone who is thoughtful, judicious, fair, balanced. What's valued in the courtroom, though, is much less valued outside it. 
We, the law-abiding, need to hold ourselves accountable for punishment policy in the United States.

\section{Public Responsibility for Sentencing Policy}

I have argued in this chapter that we should see punishment as a form of moral responsibility. It makes tangible the offender's responsibility for serious wrongdoing. But moral responsibility extends to the punisher. The punishment must be justified. And so we have looked at how judges should decide sentences.

Sentencing judges act on the authority given them by laws enacted in a democratic process. A complete view of responsibility for punishment therefore must include the public which has the final word in the democratic process. The American public's changing ideas about punishment have over the last fifty years transformed the law of sentencing and the practice of punishment in America. Where once the nation punished in a manner similar to other developed nations in the world, we now stand alone in our exceptional punitiveness. That's on us. We need to answer for it.

\section{Becoming a Specially Punitive Nation}

You have likely heard the comparisons and seen the numbers. The United States has five percent of the world's population but 25 percent of the world's prisoners. No other developed democracy in the world incarcerates at anything close to the rate that we do. Actually, no nation of any kind incarcerates on the scale that we do. For example, in 2017, United States had a total prison population of about 2.1 million. ${ }^{13}$ The next largest prison population in the world was China's, a nation with a justice system frequently targeted by human rights groups. ${ }^{14}$ With a population more than three times that of the United States, China nevertheless had fewer total prisoners: about 1.6 million people behind bars.

In 2017 the rate of incarceration in the United States (if we include both jails and prisons), was 666 per 100,000. The rate of incarceration for Great Britain (England and Wales) was 146, for Canada was 114, for Germany was $76 .{ }^{15}$ This is consistent with other differences in punishment practice between the United States and other countries. In the US, the majority of states and the federal government retain the death penalty for the most serious offenses. But capital punishment was long ago abolished in Canada and most of Europe. Life sentences, including life without chance of parole sentences, are regularly handed down in almost all American jurisdictions. Many European nations do not have life sentences of any kind. ${ }^{16}$ 
Contemporary American punishment practices are not a reflection of exceptionally high rates of crime, compared to other nations. Many nations in the world have higher crime rates than the US, including for violent crime, but imprison far fewer persons per capita. ${ }^{17}$ Looking to America's past, US crime rates today are not much different than historically, but incarceration rates are.

For most of the 20th century, the United States imprisoned at a rate similar to that of other developed democracies. That changed in the last quarter of the century. Many American jurisdictions changed their sentencing systems from indeterminate to determinate and shifted sentencing authority from parole boards to legislators, prosecutors and judges. In some jurisdictions, prison sentences for certain crimes grew much longer. This will be part of the California story told in the next chapter. Perhaps even more important, more persons were given sentences of incarceration in criminal cases. To accommodate all the new prisoners, many new prisons were built.

In the late 20th century, the politics of punishment in America changed, with major consequences for the American criminal justice system. ${ }^{18}$ Crime and its punishment became a partisan political issue, which it had not been before. This occurred at all levels of government: local, state and national. Tough on crime rhetoric became almost ubiquitous, leading to broad support for harsher sentences. Eventually both Democrats and Republicans seemed to agree that public safety required more people locked up, and for longer. Politically popular mandatory minimum sentences for drug offenses, repeat offenders and for certain crimes of violence made major contributions to increases in incarceration rates.

America's new punitiveness has drawn the most criticism for its racial inequity. If the modern increase in American prison population had affected all segments of the population equally, it would not have been as socially destructive as it has proven. ${ }^{19}$ In fact, the new punitiveness exacerbated existing racial disparities in criminal justice. Under harsher sentencing laws and policies, black and brown men and women were more likely to go to jail and prison, and to receive long sentences, even taking into account race differentials in arrest rates. African-American communities were particularly hard hit. Recall that incarceration affects more than just the person locked up. The defendant and all of his or her relations are affected as well.

Critics of what has been called mass incarceration have often blamed the war on drugs for the major shift in American punishment policy. Draconian penalties for crack cocaine and other extreme penalties in the federal criminal justice system have been particular targets of criticism. ${ }^{20}$ And it's true that the war on drugs had a disproportionate effect on the incarceration of racial minorities in the late 20th century. But if our aim is to end mass incarceration today, sentences for drug offenses are not the main problem. Currently the great majority of state prison 
inmates (and the great majority of those locked up are in state and not federal institutions) are imprisoned for crimes of violence. This means that changing our incarceration rate will require changing our response to criminal violence.

The last decade has seen a moderating trend in American punishment. There has been a modest national decline in total number of persons imprisoned from its peak in 2008. ${ }^{21}$ The degree of change should not be exaggerated, however. A disproportionate amount of the change has occurred in California, the result of actions to meet federal court orders mandating a reduction in prison overcrowding. Nor is there any guarantee that current trends will continue; they may be reversed. Finally, remember the numbers cited at the outset for total number of prisoners in the US and how those exceeded figures for any other nation? These are 2017 numbers.

These are the basic facts about America's exceptional punitiveness. My concern remains with just punishment. Is our commitment to incarceration as punishment morally justified? Can we say that this level of reliance on lock up is necessary to justice, meaning that we cannot do justice in any other less restrictive way? Are all the other nations in the world wrong in their approach, or so very different from us, that they can do justice without such heavy reliance on incarceration? Are we so very different from the nation we were before the 1970s, that we must maintain the current level of incarceration to do justice?

\section{A Constitutional Standard for Cruelty: Toward a Rule of Regard in Criminal Punishment}

While state and federal legislatures have broad authority to enact sentencing laws, there is a constitutional limit: the Eighth Amendment's prohibition on cruel and unusual punishment. This provides courts with a potentially powerful means to assess justification for severe punishment. Until recently, though, the United States Supreme Court has done little to develop Eighth Amendment rules for sentencing outside of the death penalty. That has begun to change in recent years, with decisions involving long prison sentences for juveniles. The Court has applied a principle of individualized sentencing here that largely parallels the moral regard argument that I have been making throughout. To explain the full significance of this development, though, some historical context is required.

The United States Supreme Court has long struggled with the meaning of cruel and unusual punishment. Justices generally agree that the Eighth Amendment prohibits certain torturous methods of punishment that were allowed under 18th century English law, punishments that the framers believed were too "sanguinary" (i.e., bloody). But modern punishment is designed to be nonphysical. In fact, with 
new penal technology, jails and prisons operate in a more hands-off fashion than ever before. And although punishment discourse in the public arena frequently flies to extremes, I do not believe we are about to reinstitute live disembowelment as part of capital punishment or (I hope) any other physically torturous method of punishment. Whether certain modern punishments, particularly solitary confinement, represent a form of psychological cruelty that should be barred under this line of authority, is another question. I will have more to say about solitary confinement in Chapter 6.

The Court has also held that punishment is cruel if the punishment is disproportionate to the offense and offender. Recognizing that both retribution and deterrence require a close relation between severity of crime and severity of punishment, the Court has held that a sentence of incarceration is unconstitutional if it is "grossly out of proportion to the severity of the crime." 22 This is, and was designed to be, a highly deferential rule. Under it, even very long prison terms for relatively minor drug and nonviolent property offenses have been found constitutional. ${ }^{23}$

Our concern remains with long sentences for criminal violence. What are the current constitutional limits here? What should they be? To answer, we must turn to decisions on capital punishment, because it is here that the Supreme Court first established the principle of individualized sentencing. ${ }^{24}$

In 1972, in one of the more surprising decisions of the late 20th century, the US Supreme Court by a $5-4$ decision overturned all existing death sentences and all extant death penalty laws in the nation. ${ }^{25}$ The case of Furman v. Georgia was surprising because just the previous term, the Court had rejected by a 6-3 vote, a basic constitutional challenge to the death penalty. ${ }^{26}$ The Furman case left many wondering why the Court had shifted on the death penalty, and more importantly, what the decision meant. The Furman decision was comprised of nine different opinions by the nine different justices. Among the five voting to overturn all death sentences and laws, there was no clear consensus about why current death penalties were unconstitutional. Complaints that existing laws permitted arbitrary and capricious judgments by juries resonated among the five justices, but what that meant for the future of the death penalty was quite uncertain.

Many state legislatures quickly passed new death penalty laws that they believed would fit the Court's stated concerns. The states took essentially two approaches: guided discretion and statutorily mandated death. States that chose guided discretion established a two phase trial in capital murder cases. In the first, guilt phase, jurors were required to find the defendant guilty of a statutorily designated capital offense. Then at a second, penalty phase, the jury would decide between life or death for the defendant, guided by statutory aggravating and mitigating factors. Meanwhile other states defined 
capital offenses more narrowly, and then mandated that death should be the penalty for anyone convicted of such an offense.

In 1976, the Court considered the new death penalty statutes enacted by four states: Louisiana, North Carolina, Florida and Texas. The Court approved the laws of Texas and Florida, which took different forms of the guided discretion approach, but disapproved the death penalty schemes of Louisiana and North Carolina which established mandatory death for certain offenses.

In the Louisiana and North Carolina cases, the Court held that a jurisdiction could not make the death penalty automatic upon conviction. ${ }^{27}$ Not even firstdegree murder by a prisoner serving a life sentence could support a mandatory death penalty the Court decided. ${ }^{28}$ To sentence a defendant to death, jurors needed to have discretion to choose between life and death based on their own assessments of the defendant and his offense. That judgment could not be made ahead of time by the legislature, via a statutory mandate.

In these and later cases, the Court held that at the penalty phase in a capital case, states cannot limit the kind of evidence that the defense may present to jurors to argue for life. Nor can states restrict how mitigating evidence is considered by the jury. Restrictions of either kind violate the defendant's right to present evidence about his own unique qualities as a human being. This has become known as the right to individualized sentencing.

A process that accords no significance to relevant facets of the character and record of the individual offender or the circumstances of the particular offense excludes from consideration in fixing the ultimate punishment of death the possibility of compassionate or mitigating factors stemming from the diverse frailties of humankind. It treats all persons convicted of a designated offense not as uniquely individual human beings, but as members of a faceless, undifferentiated mass to be subjected to the blind infliction of the penalty of death. ${ }^{29}$

The call of moral regard rings clearly here. At least in death cases, the sentencer must have the opportunity to see and consider the uniqueness of the person punished. The defense must have every chance to make the sentencer care for the good of the defendant and his life.

For many years, the Court limited the individualized sentencing principle to death penalty cases. The Court notably declined to follow this line of authority when it assessed life sentences mandated by California's Three Strikes laws in the 1990s. Here the Court relied on its earlier gross disproportion decisions to approve life sentences mandated by statute even for persons convicted of nonviolent property offenses. ${ }^{30}$ 
Recently the Court has returned to the individualized sentencing principle for juveniles sentenced to life without chance of parole. In Graham v. Florida, the Court struck down an LWOP sentence for a juvenile convicted of robbery, finding a mismatch between the extreme punishment given and the lesser blameworthiness of youth (defendant Graham was 16 at the time of his last offense) and the lesser severity of his offense (attempted robbery and robbery rather than homicide). The most important case for our purposes, though, was the Court's 2012 decision in Miller v. Alabama. ${ }^{31}$

In Miller, the Court struck down two different state penalty schemes that required a sentence of LWOP for first degree murder, regardless of the defendant's age at the time of the offense. The Court held that these laws did not permit the sentencer to consider two key mitigating factors related to youth: the lesser blameworthiness of juveniles and their greater capacity for change. To put this in terms of moral regard, the mandatory LWOP laws precluded sentencer consideration of the unique person of young defendants and their future good.

I believe that life imprisonment can never be justified unless we have assurance that the sentencer attempted individual regard for the punished in the sentencing decision process. When the defendant's serious wrongdoing has led to serious punishment, we should ask first whether law of the jurisdiction allowed the sentencer to consider the unique person of the offender and his or her good in reaching her decision. If yes, then we ask whether the sentencer actually did consider the unique person of the defendant and his or her good in sentencing.

\section{Conclusion}

Punishment is a form of moral responsibility that, like any form of responsibility, can be accepted or resisted by its subjects. In criminal justice this is as true for punishers as for those punished. The difference is that we spot their resistance efforts easily; our own we mostly miss.

We see right through the minimization and responsibility avoidance of offenders. I only did it once. I never meant for anyone to get hurt. I did not know it (the gun, the drugs, the stolen property) was there. I did not know they were going to do that. Really, I was just in the wrong place at the wrong time. It's not that these claims are always false, but they cannot be true as often as they are made.

Defendants who are veterans of the system have their own language for keeping blame at arm's length. They speak of "picking up" cases which lead to incarceration, rather than of doing anything wrong. Admitted crimes are described as mistakes - messing up - rather than ascribed to moral fault. One hears of "lifestyle" choices later rejected, without mention of the kinds of wrongdoing that define the 
lifestyle. The machinations of prison gangs, including the systematic use of violence for control, drugs, money and sex, are referred to as prison "politics." For those still in gang life, there is talk of "putting in the work," meaning doing violence or other wrongs on the gang's behalf.

But calling offenders on their efforts to escape full blame is easy. What about us, in our role as punishers? How willing are we, the law-abiding, to accept moral responsibility for the pain that we very deliberately inflict in ordering (or supporting) long terms of incarceration? That's a form of responsibility we often try to evade, in many creative ways. I will sketch a few of the most important here.

Some say, Punishment is not on me. It's not on us. It's the law. Except that in a democracy, the law of punishment is the product of public choice, direct and indirect. This is our law. And we know that law can be unjust. It can be morally wrong.

A variation on the same theme is to treat punishment as if the only choice involved was the offender's. Don't do the crime if you can't do the time. This slogan makes a close moral connection between crime and punishment, a connection which I have been at some pains to defend. But it elides the responsibility of the person who decides punishment. It implies that the connection between crime and punishment is organic, that punishment follows crime as night follows day, or spring follows winter. But nature does not do responsibility. We do. Humans must decide whether incarceration is warranted, and if so, for how long. Punishment may be just or unjust, according to our decisions.

Situating most prisons far from urban centers and making access difficult for citizens helps us avoid feeling the weight of punishment. The worst pain of punishment, which comes in the days and months and years and even decades of incarceration, occurs long after most of us have turned to other matters, imagining the case done with the ordering of a sentence. For the public, the lived consequences of punishment go unseen.

Mandatory sentencing laws, which will be the subject of the next chapter, offer another form of potential solace for the potentially guilt-stricken punisher. Such laws eliminate judicial discretion so that judges may honestly say that the sentence given is what the law requires and not the judge's choice. Yet a choice has been made. It's just that the real decision-makers-voters and elected officials-chose long ago before the case was ever called in court. The real decisionmakers decided sentence without ever knowing the particulars of the offense or the offender.

And finally, we, the law-abiding, can and often do, avoid carrying the full moral weight of punishment by name-calling. We condemn not conduct but character. They are bad people, we are good. They are Criminals, we are Law-Abiding. They are not just individuals who have been convicted of certain crimes; they are people 
defined by their crimes. They are Murderers, Rapists, Robbers. And a person defined by evildoing is not someone we need to care about.

Name-calling places the full moral weight of punishment on the offender, leaving none for the punisher. My hands, our hands are clean, the punisher declares. This is all your doing. There are no mixed emotions here, no caveats or qualms. There is only disgust and righteous anger.

All these forms of responsibility avoidance make ordering harsh punishment much easier for the punisher.

But punishment decisions should be hard.

\section{Notes}

1 Jeffrie Murphy, Moral Epistemology, the Retributive Emotions, and the "Clumsy Moral Philosophy" of Jesus Christ, in Punishment and the Moral Emotions: Essays in Law, Morality, and Religion (New York: Oxford University Press, 2012), p. 42.

2 On the creation of the penitentiary generally, see Adam Jay Hirsch, The Rise of the Penitentiary: Prisons and Punishment in Early America (New Haven: Yale, 1992); David Rothman, The Discovery of the Asylum: Social Order and Disorder in the New Republic (Piscataway: Aldine Transaction, 2002); Gustave de Beaumont \& Alexis De Tocqueville, On the Penitentiary System in the United States and its Application in France, ed. H. Lantz., trans. F. Lieber (Carbondale: S. Illinois Univ. Press, 1964, orig. 1833).

3 LifeSafer, The History of Drunk Driving Laws in the US, found at https://www.lifesa fer.com/blog/the-history-of-drunk-driving-laws-in-the-u-s/. For information about Mothers Against Drunk Driving, see www.madd.org/.

4 For an introduction to the literature, see Marie Gottschalk, Caught: The Prison State and the Lockdown of American Politics (Princeton, NJ: Princeton University Press, 2015); Michelle Alexander, The New Jim Crow: Mass Incarceration in the Age of Colorblindness (New York: New Press, 2012); Michael Tonry, Punishing Race (New York: Oxford University Press, 2011); Jonathan Simon, Governing Through Crime: How the War on Crime Transformed American Democracy and Created a Culture of Fear (New York: Oxford University Press, 2007). See also National Research Council, The Growth of Incarceration in the United States: Exploring Causes and Consequences (Washington, DC: National Academies Press, 2014).

5 To be clear, this is a fictitious case.

6 Expressive theories of punishment are often associated with the French sociologist Emile Durkheim. See The Division of Labor in Society, trans. W.D. Halls (New York: Free Press, 1984), pp. 62-3. See also Joel Feinberg, Doing and Deserving: Essays in the Theory of Responsibility (Princeton, NJ: Princeton University Press, 1974), pp. 98-105.

7 But it is also true that the experience of power in robbery is a significant motivator for robbers. See Jack Katz, Seductions of Crime: Moral and Sensual Attractions in Doing Evil (New York: Basic Books, 1988).

8 I do not consider restorative justice here because it normally functions as an alternative to criminal adjudication in the courts. Here I focus on how to determine punishment 
within the court system. For an introduction to restorative justice, see Howard Zehr, The Little Book of Restorative Justice (Intercourse, PA: Good Books, 2002).

9 Thomas Jefferson famously viewed the right of the people to serve on juries in the judicial system as even more important than the right to vote for legislative representatives. In 1789 he wrote: "Were I called upon to decide whether the people had best be omitted in the legislative or the judiciary I would say it is better to leave them out of the legislative. The execution of laws is more important than the making of them." Letter of the Abbe Arnoux, July 19, 1978, 15 Papers of Thomas Jefferson, ed. Julian P. Boyd (Princeton, NJ: Princeton University Press, 1958), pp. 282-3.

10 See Jed S. Rakoff, Why Innocent People Plead Guilty, N.Y. Rev. Books, Nov. 10, 2014; Stephanos Bibas, Plea Bargaining Outside the Shadow of Trial, 117 Harv. L. Rev. 2463, 2491-3 (2004).

11 There is a prison saying to this effect: "Bad dads bring home strippers. Bad moms make serial killers. Absent dads make cons (convicts)."

12 Joe, an inmate in California prison, Wisdom from the Cells, Liturgy for Palm Sunday, Jesuit Restorative Justice Initiative, 2015.

13 www.prisonstudies.org, July 17, 2017.

14 U.S. Dept. of State, 2016 Country Reports on Human Rights Practices, East Asia and the Pacific, China 3/3/2017, found at http://www.state.gov/j/drl/rls/hrrpt/humanrightsrep ort $/$ index.htm?year $=2016 \&$ dlid $=265328$

(9/30/2018); Human Rights Watch, World Report 2017, China, found at https:// www.hrw.org/world-report/2017/country-chapters/china-and-tibet (7/25/2017).

15 www.prisonstudies.org.

16 See, e.g., Death Penalty Information Center, Abolitionist and Retentionist Countries at https://deathpenaltyinfo.org/abolitionist-and-retentionist-countries?scid=30\&did= 140; Vera Institute of Justice, Sentencing and Prison Practices in Germany and the Netherlands: Implications for the United States, October 2013. For a useful historical account of how Europe and the US diverged on criminal punishment, see James Whitman, Harsh Justice: Criminal Punishment and the Widening Divide between America and Europe (New York: Oxford University Press, 2003).

17 For example, see homicide rates in Latin America. Alejandro Sanchez Inzunza, A Place Used to Death, New York Times, July 16, 2017.

18 A cautionary note on this standard phrase: the American criminal justice system. The notion of a singular criminal justice system in the US falls apart on close examination. There are a total of 52 separate sovereigns in the United States, each with the authority to convict and punish: the 50 states, the federal government and the military (this excludes Native American tribal jurisdictions which have their own, limited punishment powers). But this is just the beginning of jurisdictional differences. Within states, there are variations between city and county authorities, with different prosecutorial offices, police departments and jails, with separate funding, politics and interests, challenges and philosophies. What might be true for sentencing and punishment policy in Jacksonville, Florida will not be true for Miami, Florida. Police, prosecutors and courts function quite differently in Bakersfield and Fresno than Los Angeles or San Diego, even though all are in the southern half of California. While trying to see the big picture on criminal justice matters in the US - we will get quite lost without it - many 
of the most important decisions in the criminal system are made at the local and state level, where differences in values, laws and policies can be major.

19 Of course one might wonder whether a sharp increase in incarceration would have been so popular in the US if it had affected whites as much as it did minorities.

20 See Alexander (2012); Michael Tonry, Malign Neglect: Race, Crime and Punishment in America (New York: Oxford University Press, 1995).

21 At the end of 2015, an estimated 1,526,800 were locked up in federal or state prison in the US. This was the smallest total number so held since 2005. Bureau of Justice Statistics, Prisoners in 2015, December 2016. An estimated 721,300 inmates were held in city and county jails on an average day in 2015. The highest recorded number for average jail population in the US was 776,600 in 2008. Bureau of Justice Statistics, Jail Inmates in 2015, December 2016.

22 Gregg v. Georgia, 428 U.S. 153, 173 (1976).

23 In the realm of long drug sentences, the Court has found constitutional 40 years in prison for possession of nine ounces of marijuana (Hutto v. Davis, 454 U.S. 370 (1982)); life without chance of parole for possession of 672 grams of cocaine (Harmelin v. Michigan, 501 U.S. 957 (1991)). In cases involving life sentences for repeat offenders convicted of nonviolent property offenses, the Court has approved a life with chance of parole for obtaining money by false pretenses (Rummel v. Estelle, 445 U.S. 263 (1980)) but found unconstitutional a life without chance of parole sentence for issuing a no account check in the amount of $\$ 100$ (Solem v. Helm, 463 U.S. 277 (1983)).

24 I should explain why I do not otherwise consider the death penalty in this chapter, or indeed, in most of the book. As the Supreme Court has repeatedly stated: "death is different." The Court says this to emphasize that the substantive rules and procedures required by the Eighth Amendment in death cases may not be required in other cases. Despite its obvious and important connection to the themes and problems covered here, death as a punishment presents issues different from even the longest prison term. And once we start their consideration, it is hard to stop. The death penalty has a way of taking over every punishment discussion in which it is raised, leading to the neglect of the most common punishments used. I want to avoid that here.

25 Furman v. Georgia, 408 U.S. 238 (1972).

26 McGautha v. California, 402 U.S. 183 (1971).

27 See Sumner v. Shuman, 483 U.S. 66 (1987); Skipper v. South Carolina, 476 U.S. 1 (1986); Roberts v. Louisiana, 431 U.S. 633 (1977); Woodson v. North Carolina, 428 U.S. 280 (1976); see also Eddings v. Oklahoma, 455 U.S. 104 (1982); Lockett v. Ohio, 438 U.S. 586 (1978); Gregg v. Georgia, 428 U.S. 153, 173 (1976).

28 E.g., Sumner v. Shuman, 483 U.S. 66 (1987).

29 Woodson v. North Carolina, 428 U.S. 280, 304 (1976).

30 Ewing v. California, 538 U.S. 11 (2003); Lockyer v. Andrade, 538 U.S. 63 (2003).

31567 U.S. 460. 


\section{CRUELTY BY LAW}

\section{Mandatory Life in California}

They're little more than animals. They look like people, but they're not. And the unfortunate thing is they're preying on us. And we have to get them out so the rest of us can go on living our lives.

Mike Reynolds, sponsor of Three Strikes law in California, on the repeat offenders targeted by the law

I can remember, all too clearly, the moment of dread I felt on arriving home after a trip or even a long day at work. I would unlock the front door, push inside and quickly survey the interior to make sure that no one had broken in while we were gone. Most of the time, all was as we had left it. The mess I saw was our mess, not the disturbance of an intruder. But the fear of a break-in was lodged in my body from past experience. I knew it could happen again. For a while, it seemed almost inevitable.

From 1980 through the early 1990s we lived in four different places in the city of Los Angeles. In two of these places we were burglarized. In a third we were not broken into, but our neighbors were, and I found bent screens on our bedroom window indicating that someone had tried our home as well. The fourth place was a small garage apartment reached from a narrow driveway behind a large apartment building that no one but its immediate neighbors even knew existed.

Once my wife and I went to an event at UCLA and parked our car in a university parking garage. We found it later that night sitting at an odd angle. It was jacked up and the left side wheels had been stolen. At the first house we owned, a bungalow on a broad street with a leafy, peaceful look that made it a popular location for filming, our family's van was stolen from in front of the house. Both my wife and I had our wallets stolen in public places: a laundromat and a movie theater. 
Once, as she jogged around a landmark city reservoir, a passing motorcyclist grabbed at my wife between her legs from behind, then rode off.

This personal history was nothing unusual for LA at the time. Some in the city fared better. Some fared much, much worse. In general the police were overburdened and mostly seemed to go through the motions of investigating crimes like ours. No one was ever arrested or prosecuted for any of the crimes we reported - and we reported all of them except perhaps the wallets. None of our property was recovered except for the van, which reappeared about a month after it was taken, missing its radio and bench seats.

We lived through the Rodney King riots of 1992, watching them start on the small black and white television in our kitchen. We watched the vicious beating of Reginald Denny, pulled from his truck at the intersection of Florence and Normandie, the episode captured by a circling news helicopter. For the next five days we stayed home under smoking skies while chaos prevailed not far away. Several buildings near my school were destroyed by fire.

During these years, discussion of crime was a staple of conversation, along with the price of real estate. This was Los Angeles in the late 20th century.

I begin with these stories of crime and violence in California in the 1980s and 1990s because it helps explain why a state and nation changed so much in its punishment practices. This chapter will focus on California and two forms of mandatory life sentences that were enacted in the late 20th century.

Although social scientists generally distrust personal stories, believing them to be too random and individual to serve as a reliable source of information, I think stories like these are critical to understanding the advent of severe punishment in America. We need to appreciate the fear and pain that drove legal change.

This is a book about justice for crimes of violence, and the changes in punishment policy that we will track here were largely driven by concerns about violent crime, but that does not mean we should leave so-called property crimes out of the picture. Most of the crimes against our family were to property, but they felt very much like crimes against the person. Take residential burglary. Often categorized as a nonviolent offense against property, to victims it is a frightening, infuriating and very personal invasion of space. I can remember feeling helpless rage at the violation of our home that lasted for months and years afterwards. As a father and husband I felt acutely the failure to keep my home safe from intruders. I took to hiding a knife, and later a lead pipe beneath my side of the bed at night.

If you had asked me in those years about criminal justice, I would likely have given a studied answer about retribution and deterrence, poverty, social structure and common patterns of criminal behavior. During these years I was a law student, a law clerk to a federal judge, a federal prosecutor and a law professor. And yet in the basic experience of crime, I don't think I was much different than any other 
Californian. The enactment of severe sentencing laws in United States in the late 20 th century came out of the hurt of increased crime in the nation, particularly increased crimes of violence. This led to a new public rhetoric about punishment that was based on personalized morality. Punishment law became a blunt instrument to crush evil offenders and secure the lives of the law-abiding.

The story of California's mandatory life sentences illustrates (again) the attractions and dangers of good guys vs. bad guys morality. By depicting all offenders as Criminals, tough on crime politicians promoted laws that had disproportionate effects on the most disadvantaged citizens. These laws were part of a larger trend in sentencing in which the burden of incarceration fell even more heavily on poor minority males with scanty education and significant mental and emotional problems.

For the injustice of these laws we can if we wish blame ambitious politicians, a sensationalist media and a racially prejudiced electorate. But even in blaming we must avoid good guys v. bad guys. In the late 20th century, legitimately afraid and angry about crime, Californians became swept up in the simplifying passions of payback justice. They felt threatened by a criminal Enemy, making extreme sentences seem necessary to public safety. The experience of criminal violence inspired extreme and sometimes clearly unjust punishments. Wrongdoing inspired wrongdoing.

\section{The Origins of Mandatory Life in California}

This chapter is about two major sentencing changes in California: the Three Strikes law for repeat felony offenders and mandatory life for juvenile murderers. The Three Strikes law mandated a minimum sentence of 25 years to life for certain repeat felons, even for a nonviolent third offense. Laws mandating life in prison for juvenile murderers, including life without chance of parole, were prompted by fears of a deadly new generation of delinquent youth. Similarities between these laws in their penalties, their mandates and their political origins make them a useful vehicle for exploring larger trends in punishment in California, and the nation.

The origins of Three Strikes and mandatory life for juvenile killers can be found in many factors, including the stress of a state and nation undergoing enormous demographic, cultural and economic change. Race prejudice also played a role. I begin with the phenomenon that proponents said inspired them: concern about violent crime in the late 20th century. Mandatory sentencing laws answered the needs of a public deeply fearful of criminal violence and suspicious of the abilityand willingness - of judges and other government actors to safeguard them. 


\section{Mandatory Life as a California Story}

California has always been a great state for story tellers, which makes telling its story a challenge for the historian. It can be hard to separate truth from legend.

The stories that the state tells about itself, and which it seems to invite from others, are almost always dramatic. The landscape of the state is spectacular, the climate wondrous (or can be), its people enormously varied, its dreams and conflicts outsized. Tales of crime and punishment in the state regularly make big headlines nationally and even globally. This can be a problem for a nuanced view of criminal justice, but it is also an important reality. Public perceptions matter a great deal in a state where populist movements have often rewritten government policy. So it is appropriate that we begin our story with a popular drama, a movie made and set in California, which signaled a major shift in public attitudes toward crime, punishment and the law.

\section{A New Kind of Good Guys v. Bad Guys}

The movie Dirty Harry was a big hit when it was released in 1971. It was also a cultural event. San Francisco police Detective Inspector Harry Callahan, played by the glint-eyed, clench-jawed Clint Eastwood, he of the graceful pompadour hair and long-barreled 44 Magnum, became an icon of crime fighting in America. He was a fierce, tough spoken hunter of human predators. And he was good at what he did. He brought down the bad guy when no one else could.

None of this was particularly unusual in Hollywood terms. The plot line held few surprises. What was different, and important for our purposes, was the depiction of the legal system that the detective had sworn to serve. The emotional pivot point of the movie occurs after Inspector Callahan's initial capture of the Scorpio serial killer. Only through extraordinary efforts, which nearly cost them their lives, have Callahan and his partner managed to arrest the man who killed innocents from a cowardly distance with a sniper rifle. Callahan is then called into the District Attorney's office where the chief prosecutor and an appellate judge (who also teaches constitutional law at Berkeley) await. Instead of congratulating the Inspector for his achievement, the two proceed to lecture him on constitutional law, citing prominent US Supreme Court decisions (Escobedo and Miranda) and the dictates of the Fourth Amendment. They inform Callahan that because of his egregious lawbreaking, the killer must go free. Callahan is incredulous. The audience, having seen what Scorpio can do and what his capture required, is incredulous as well. (Indeed as a former prosecutor I cannot imagine any prosecutor making these remarks or taking this legal position, even considering the constitutional law at the time.) From this point 
on in the movie it is clear that justice depends not on the law but on Inspector Callahan. Dirty Harry has two foes: a serial killer and the legal system.

The Scorpio killer is a full-on psychopath. We watch as he cold-bloodedly kills a beautiful woman swimmer and a boy on a beach with his rifle. He kidnaps, rapes and kills a 14-year-old girl. Finally he kidnaps a busload of elementary school children. As portrayed, he is pure evil, pure Enemy.

The movie and its sequels added classic tough guy lines to the American lexicon-Do I feel lucky? Well, do ya punk?; Go ahead, make my day-which celebrated righteous violence. The movie and its sequels pictured a modern society on the verge of moral and social collapse because of rampant violence. In this context the violent heroics of Det. Callahan provide the only hope of restoring order.

Clint Eastwood's Dirty Harry was the epitome of tough, violent masculinity. He is laconic, determined and quite unmoved by the negative opinions of others about his methods. A fully autonomous man, he sneers at the disapproval of others. He stands true to his values. He acts; he is not acted upon.

The movie crystallized a view of the law that drove some of the most dramatic changes in criminal justice policy in the latter part of the 20th century in the United States. The movie seemed to show that lawyers and judges could not be trusted to do justice. The hopelessness of contemporary law was symbolized by Inspector Callahan's final gesture in the movie, tossing the gold star of his detective's badge into a nearby pond.

It's true that Dirty Harry was just a movie, a made-up story with one-dimensional characters. With respect to criminal justice policy, it was a kind of propaganda piece, not a serious exploration or critique. And yet we will see its themes recurring throughout the debate about criminal justice in California in the years following its release.

\section{The Background to Mandatory Life}

Moving from fiction to fact, we need to sketch the background of crime and punishment in California in the late 20th century to understand why proposals for mandatory life became so popular in a state better known for its liberal culture and politics.

\section{Just the Facts: Violent Crime and Incarceration in California, 1966-1993}

We begin, as that famous LA TV detective Joe Friday might, with the bare facts about changes in the amount of violent crime in California in the late 20th century and the use of incarceration to punish crime. 
Rates of violent crime in California in the latter part of the 20th century followed roughly the same pattern found in the nation as a whole. From mid-century until the mid-1960s, crime rates in the United States were relatively low, meaning that crime was not an overriding issue in politics or community life. Crime rates also did not change much from year to year during this period. Then came the decade from 1966 to 1976, when the rate of violent offenses doubled or more. With some significant fluctuations, violent crime remained at very high levels until the early 1990s, when a significant and sustained decline began.

To describe these changes in more detail we turn to the standard measure for crime: the crime rate per 100,000. This counts the number of offenses in a year, by category, for every 100,000 individuals in the relevant population. Because it is tied to the number of persons in the jurisdiction at the time of measurement, it gives a proportional figure for crime according to population size. (Total numbers of crimes committed are a less reliable guide to changes in criminality because these may reflect increases or decreases in population rather than changes in the rate of crime commission.)

In 1966, California had a homicide rate of 4.7 (per 100,000). This figure more than doubled to 10.1 in 1976 and increased to 12.9, its second highest ever, in 1993. In 1966, California had 116.6 robberies per 100,000 population. As with homicide, this rate more than doubled to 269.6 per 100,000 in 1976. In 1993, the robbery rate was 398, close to its historic peak. California's crime rate for rape followed a similar but not identical pattern. The rate of sexual assault per 100,000 was 21.3 in 1966, a figure that more than doubled to 43.5 in 1976. The rate declined to 37.0 in $1993 .{ }^{1}$

Now to the second part of our statistical survey: incarceration. How was California punishing crime during the late 20th century?

California in 1966 had an incarceration rate of 144.5 per $100,000 .^{2}$ State prisons held approximately 27,500 prisoners. A decade later-a decade, recall, that saw an enormous increase in crime-the state's incarceration rate had actually declined to 95.2. Then came a sea change in punishment policy. Incarceration rates began rising steadily in the 1980s. The rate had doubled by 1986 and more than tripled by 1990. In 1993, California had an incarceration rate of 375.4 and a total number of 119,951 prisoners in state institutions. ${ }^{3}$ Increases in incarceration would continue throughout the rest of the century, with the total number of prisoners reaching a peak of 173,000 in 2006.

\section{Criminal Justice Politics: Populist Reform before Three Strikes}

In the last quarter of the 20th century, California criminal justice became political as never before. Time after time, direct voter action overturned legislation and court decisions. The people-or at least those who voted-took charge. 
The basic mechanism of change was the direct initiative. Since 1911, by gathering the signatures of a percentage of registered voters, an initiative called a proposition could be placed before state voters at the next election. Originally designed as a way to break the stranglehold of special interests on state government, notably the Southern Pacific Railroad, propositions became in the late 20th century a way for politicians, citizens, and interest groups to do an end run around the state government in Sacramento to change state law and policy. ${ }^{4}$ Taxes and criminal justice proved the most popular subjects of direct democracy in the state. Each of the criminal justice measures detailed below were approved by a clear majority of voters; several passed with a super majority.

Changes in California criminal law followed a similar pattern. Proponents made direct appeals to public fear and anger at criminal violence, often citing high profile cases of murder or sexual violence. The vulnerability of the law-abiding public to the depredations of criminals was presented as a spur to and justification for legal change. Good guys versus bad guys moralizing predominated.

Advocates of change argued that elected and appointed legal authorities in the state could not be trusted. The legislature and the judiciary were special targets of criticism. The proposed changes usually sought to overturn the decisions of state governmental actors and to redistribute authority over state law. Finally, each of these measures was part of a larger partisan and ideological struggle for power in the state. Political careers in the state often dramatically rose - and fell — based on the politician's stance on certain criminal justice propositions. Special interest groups also found enormous new power in support for popular propositions, particularly California's correctional guards union. ${ }^{5}$

The first major proposition targeting criminal justice was the 1978 Briggs initiative on the state's death penalty. Following many years of legislative and judicial wrangling over capital punishment, the initiative laid out a death penalty law applicable to most forms of first-degree murder. It overrode the more limited death penalty statute that had passed the state legislature the previous year. The proposition also made the default (noncapital) penalty for first-degree murder 25 years to life instead of a life sentence with the possibility of release on parole (however unlikely) in 7 years. It doubled the penalty for second-degree murder to 15 years to life. ${ }^{6}$ The argument in favor of the proposition that appeared on the ballot focused exclusively on the death penalty as an answer to the threat of violent crime.

CHARLES MANSON, SIRHAN SIRHAN, THE ZODIAC KILLER, THE SKIDROW SLASHER, THE HILLSIDE STRANGLER.

These infamous names have become far too familiar to every Californian. They represent only a small portion of the deadly plague of violent crime which terrorizes law-abiding citizens. 
Since 1972, the people have been demanding a tough, effective death penalty law to protect our families from ruthless killers. But, every effort to enact such a law has been thwarted by powerful anti-death penalty politicians in the State Legislature.

In August of 1977, when the public outcry for a capital punishment law became too loud to ignore, the anti-death penalty politicians used their influence to make sure that the death penalty law passed by the State Legislature was as weak and ineffective as possible.

That is why 470,000 concerned citizens signed petitions to give you the opportunity to vote on this new, tough death penalty law....

Your YES vote on Proposition 7 will help law enforcement officials to stop violent crime-NOW. ${ }^{7}$

In 1982, the Victims Bill of Rights (Proposition 8) enacted a number of changes in California's substantive and procedural criminal law. The proposition considerably narrowed both the state's insanity defense and the ability of defendants to gain acquittal or a lesser conviction for diminished capacity based on mental illness. The proposition eliminated the power of state appellate courts to exclude evidence on the basis of so-called independent state grounds, meaning based on violations of the California constitution rather than the federal constitution. This meant that the state courts would now have to follow generally more conservative federal court decisions on police interrogations and searches and seizures. In an effort to increase sentences, the proposition sought to eliminate plea-bargaining in specified criminal cases. The proposition permitted broader use of prior convictions in the cross-examination of witnesses, a change which increased the risks for defendants who testified in their own defense. And the proposition gave victims the right to speak at sentencing and parole hearings.

Again the arguments presented to voters on the ballot in favor of the proposition focused on violent crime. Again the Legislature was depicted as an obstacle to needed public safety measures. This time, the state's appellate courts were harshly criticized as well. California Attorney General George Deukmejian (who would later win election as Governor using his tough on crime credentials) wrote the following as part of the ballot arguments in support of the proposition:

Crime has increased to an absolutely intolerable level.

While criminals murder, rape, rob and steal, victims must install new locks, bolts, bars and alarm systems in their homes and businesses. Many buy tear gas and have guns for self-protection. FREE PEOPLE SHOULD NOT HAVE TO LIVE IN FEAR. 
Yet, higher courts of this state have created additional rights for the criminally accused and placed more restrictions on law enforcement officers. This proposition will overcome some of the adverse decisions by our higher courts.

THIS MEASURE CREATES RIGHTS FOR THE VICTIMS OF VIOLENT CRIMES. It enacts new laws that those of us in law enforcement have sought from the Legislature without success ...

There is absolutely no question that the passage of this proposition will result in more criminal convictions, more criminals being sentenced to state prison, and more protection for the law-abiding citizenry.

IF YOU FAVOR INCREASED PUBLIC SAFETY, VOTE YES ON PROPOSITION 8.

In 1986, three justices on the California Supreme Court became the target of a statewide political campaign because of their decisions in criminal cases. By law, state appellate judges at the end of their appointed terms face an up or down vote by the electorate. If a majority of voters vote no, the judge is removed and the governor appoints a replacement. In the past, the retention of appellate judges had been virtually automatic. Few voters even knew who they were. Now a well-funded and well-organized campaign targeted Chief Justice Rose Bird and associate justices Cruz Reynoso and Joseph Grodin. Each had been appointed by the previous governor, Democrat Jerry Brown.

The campaign focused primarily on Chief Justice Bird who been the Santa Clara County Public Defender before joining the court. Advocates for a no vote argued that Bird and the other two targeted justices had sought to negate the state's death penalty law by consistently reversing death sentences for defendants (though not convictions) and by delaying decisions in death penalty cases. In the end, a majority of voters cast no votes for each of the targeted justices. This permitted the new Republican governor, George Deukmejian, to appoint three new conservative judges to the high court. Almost overnight, what had been for generations a liberal court on criminal justice issues became a conservative one.

In 1990, Proposition 115 was approved by voters, another compendium of legal changes to make prosecutions swifter and more likely to succeed and punishments more severe. Among its important provisions were changes to speed up preliminary hearings and jury selection. It also allowed juveniles aged 16 or 17 convicted of first-degree murder with special circumstances to be sentenced to life without chance of parole (instead of just 25 years to life). The ballot arguments in favor of the proposition hit almost identical notes to those used for earlier criminal justice propositions, attacking both the legislature and appellate courts as obstacles to public safety. ${ }^{8}$ 


\section{The Experience of Crime and Disorder: California in the Early 1990s}

As the 1990s began, violent crime was a significant concern for many Californians, especially those who lived in urban areas. Despite the changes that had been made to California law in the previous two decades to make prosecutions more effective and sentences more severe, the facts on the ground did not seem to have improved. Indeed, new threats of criminal violence seemed to arise all the time.

In the late 1980s a new drug had appeared, bringing violence and wreaking social havoc: crack cocaine. More powerful and cheaper than powder cocaine, it created large numbers of new addicts with terrible effects on families and neighborhoods, especially in minority communities. The crack cocaine trade was both lucrative and violent as dealers and their drug organizations fought for territory. This contributed significantly to an increase in violent crime in the latter part of the decade.

Meanwhile gangs in California grew more numerous and lethal. The percentage of young people in the population was at its highest since the baby boomers had come of age. This gave gangs plenty of potential recruits. The drug trade provided ample money and turf to fight over. Immigration, especially from Mexico, brought large numbers of young people in California who grew up less restrained by family and community ties, typical of first generation immigrant youth. Some were drawn to gangs for their promise of belonging. Power, money, sex and violence also had their attractions. But the critical new fact about gangs in California (and throughout urban America) was not their burgeoning numbers but the ready availability of powerful guns. Where before gangs fought with fists and clubs, knives and an occasional firearm, now even young teens had access to modern semi-automatic pistols and rifles, which they loved to use. Drive-by shootings and carjackingsarmed robberies of vehicles-became regular headline news.

And then, especially for the residents of Los Angeles, the state's biggest urban area, there was Rodney King. The videotaped beating of King by a swarm of Los Angeles Police Department officers following a car chase was for the AfricanAmerican community in Los Angeles, and many others, the latest and most outrageous evidence of the Police Department's racism and brutality. The LAPD had long compensated for its small size relative to the city's population and geographic sprawl by using militaristic tactics and overwhelming force against targeted individuals and groups. But this arrangement, with a largely white police department aggressively policing an increasingly minority city, was no longer viable. When a state prosecution of city police officers for brutality against King ended in acquittal on virtually all charges, the city exploded into violence, leading to six days of arson, looting, beatings and shootings that took 53 lives and caused more than a billion 
dollars in damage. Only the arrival of armed troops from the state national guard, army and marines was sufficient to restore order.

This was California in the early 1990s.

There was one other important element contributing to Californians' sense of unease during this time. The media had changed how it covered crime. California had always had more than its share of high-profile crimes. From the Manson family in the 1960s, through the serial killers of the 1970s and 1980s (the Freeway Killer, the Night Stalker in southern California, the Zodiac killer in San Francisco), the state always seemed to have a sensational case going that attracted media coverage from local, national and even international reporters. But in the late 1980s, the advent of 24-hour cable news changed how the dominant television medium covered criminal violence. Television's ability (and ratings-driven need) to cover high profile cases at great length and with great intensity (though not necessarily with great insight) raised public concerns with violence and disorder. Continuing through the 1990s, coverage of violent crime increased even as crime rates began a significant decrease. ${ }^{9}$

\section{The Passage of Three Strikes}

It is a story often told in California, the story of how Three Strikes came to be law. It can be told in many ways, as a story about changing politics, about race and class, about media, political ambition and the use and abuse of public fear and anger, or about the failure of legal institutions to maintain the public's trust. ${ }^{10}$ Whatever the theme, the story can never be told without the murders of two young people that inspired this law. The political forces that gathered behind Three Strikes found their driving force in the killings of 18-year-old Kimber Reynolds in 1992 and, especially, 12-year-old Polly Klaas in 1993.

Kimber Reynolds was standing next to her car in downtown Fresno, California on the night of June 29, 1992, when two men drove up beside her on a motorcycle. The man on the back of the motorcycle, Joe Davis, grabbed her purse in a robbery attempt. When Kimber Reynolds did not immediately release the purse, Davis pulled a gun from his waistband and shot her in the head. It was a fatal wound. Kimber's father was Mike Reynolds, a Fresno area photographer. Reynolds turned his grief and anger to action, seeing in his daughter's murder evidence of a major shortcoming in the California justice system. It turned out that Joe Davis had multiple felony convictions and so did the motorcycle's driver who acted as an accomplice in the robbery. Reynolds believed that both should have been in prison at the time, which would have prevented his daughter's murder. "I'm going after these guys in a big way, the kind of people who would murder little girls in this way," Reynolds told California Gov. Pete Wilson. ${ }^{11}$ 
With the help of sympathetic lawyers, Reynolds put together a broad legislative proposal for increasing the punishment of repeat offenders. This was introduced in the California legislature, but was defeated in committee. Reynolds then turned to the initiative process. He gained powerful financial and political backers for this effort, most importantly the National Rifle Association and the California Correctional Peace Officers Association. The effort to register the required number of voter petitions was going slowly, however, until the murder of Polly Klaas. ${ }^{12}$

Polly Klaas, a 12-year-old girl, was kidnapped from the bedroom of her mother's home in Petaluma, California during a slumber party. For nine excruciating weeks, volunteers and law enforcement searched for the young girl. Television coverage of the search for the missing child was unrelenting. Then forensic evidence led police to parolee Richard Allen Davis, who was arrested on another charge. Davis soon confessed to killing the girl. He told police where Polly Klaas's body could be found. The girl's body was recovered in a field; she had been sexually assaulted.

Davis had long ago shown himself to be seriously dangerous. He had a long string of convictions dating back to early adolescence. Many of his adult offenses involved violence, including sexual violence. He was at liberty prior to his latest arrest because he had been released after eight years in prison for robbery and kidnapping. ${ }^{13}$ Many asked, what was he doing out in free society?

Mike Reynolds approached the Klaas family to join his effort to pass a new repeat offender law in California. Appalled by Davis's criminal history, they agreed. ${ }^{14}$

The Klaas murder fundamentally changed the political atmosphere in the state on repeat offender legislation. The question now was not whether a three strikes bill would become law but what kind of three strikes bill would be enacted. Four separate bills increasing the punishment of three-time felons passed the legislature and went to the governor's desk. One was a measure supported by the California District Attorneys Association which provided for a life sentence for anyone convicted of three serious and violent offenses. Gov. Pete Wilson however, signed into law the Reynolds version of three strikes, which was significantly broader. The new statute permitted a life sentence even when the third "strike" was a nonviolent offense.

In order to ensure that Three Strikes would be hard to change by future legislatures, Reynolds continued with his push to put the measure on the ballot as a state constitutional amendment. It garnered the requisite signatures in record time.

The ballot argument for the proposition kept the focus solely on violent crime. It began with two paragraphs about the murder of Kimber Reynolds and the campaign of her father to "spare others from the senseless tragedy that killed his daughter." Its third paragraph set out its aim: "3 Strikes keeps career criminals, who 
rape women, molest innocent children and commit murder, behind bars where they belong." $" 15$ The measure passed by a wide margin.

\section{The Enactment of Mandatory Life for Juvenile Murderers}

Unlike California's Three Strikes law, the legal enactments that mandate life imprisonment for certain juvenile offenders did not come in a single piece of legislation or initiative. Instead we find an accumulation of provisions enacted as part of propositions and legislation across a number of years. Our main focus will be on Proposition 21, passed in 2000, because this was when California voters made their most deliberate decision to increase punishments for juvenile wrongdoers.

The first piece of the legal puzzle was the determination, by proposition in 1978, to make the default punishment for first-degree murder 25 years to life. Next came a gun enhancement law championed by Mike Reynolds called "10-20-life." Reynolds' effort to qualify this for the 1996 ballot failed, but the proposal was taken up in the legislature in 1997. With a significant modification that reduced the number of felonies to which it would apply (eliminating assaults with deadly weapons) the bill won the approval of both Democrats and Republicans in the legislature. It was signed by Gov. Pete Wilson.

Now we come to Proposition 21, formally known as the Gang Violence and Juvenile Crime Prevention Act of 1998. As with Three Strikes and other criminal justice propositions, this was a complex legislative proposal with many provisions that would be comprehensible only to attorneys who worked in the field-in this case the field of juvenile criminal law. The Findings and Declarations section which opened the Proposition, however, gave the voting public a clear sense of its proponents' motivations and aspirations:

While overall crime is declining, juvenile crime has become a larger and more ominous threat. ... Criminal street gangs and gang-related violence pose a significant threat to public safety and the health of many of our communities. Criminal street gangs have become more violent, bolder, and better organized in recent years. ... Gang-related crimes pose a unique threat to the public because of gang members' organization and solidarity. Gang-related felonies should result in severe penalties. Life without the possibility of parole or death should be available for murderers who kill as part of any gang-related activity.

The ballot language repeated the prediction of some criminologists that the nation would soon see a wave of especially violent juvenile offenders. This prediction was used to argue for increased prosecutions of juveniles as adults, the opening of 
juvenile proceedings to the public in some cases (juvenile proceedings are normally closed), and increased penalties for violent offenders.

Dramatic changes are needed in the way we treat juvenile criminals, criminal street gangs, and the confidentiality of the juvenile records of violent offenders if we are to avoid the predicted, unprecedented surge in juvenile and gang violence. Californians deserve to live without fear of violent crime and to enjoy safe neighborhoods, parks, schools. This act addresses each of these issues with the goal of creating a safer California, for ourselves and our children, in the Twenty-First Century. ${ }^{16}$

\section{California's Experience with Mandatory Life}

Proponents of mandatory life penalties in California promised that they would increase public safety and do justice for victims. Opponents warned that sentencing laws alone would not change crime rates, but they would produce unjust results in many cases. So what actually happened when mandatory life sentencing went into effect? Was the public protected from criminal violence as a result? Was justice done? To provide a complete answer on the laws' crime suppressive effects would require a different book than this, but I can sketch some basic points about deterrent consequences-and justice.

\section{Impact on Violent Crime}

The defenders of mandatory life penalties say that these laws did a great deal to improve public safety in California. They point to the substantial and steady declines in violent crime that occurred in California in the 1990s after Three Strikes was passed, continuing into the early part of the 21 st century when mandatory life for juvenile murderers was fully in place. As social scientists are wont to say, however, correlation is not causation.

Most experts in criminology doubt that increased punishment as the result of laws like Three Strikes contributed much to the decline in crime that occurred in the state. California's crime decline was part of a larger trend throughout the United States from the early 1990s into the early 21st century. A similar trend occurred in Canada, a nation with very different punishment practices. Looking at different American jurisdictions, there is no obvious connection between severe punishment laws and crime rates. For example, focusing for the moment on Three Strikes, California's crime rate decline was no greater than that experienced by states without such a law. Within California, crime rates did not vary according to 
how county prosecutors used Three Strikes. Crime rates in San Francisco, where the three strikes provision was least used by prosecutors, declined as much as, or more than, in counties where it was often used.

As to crimes of violence committed by juveniles, there was a very significant decline in juvenile violent crime in the 1990s and the first decade of the 21st century, but the decline was well underway before the passage of Proposition 21. And equally impressive declines in juvenile violence were seen in jurisdictions that did not have similarly severe sentencing laws.

None of this proves that the enactment of mandatory life sentences had no impact on crime, however. One recent study indicated that for felons with two strike convictions, Three Strikes likely brought about a 20 percent decline in new arrests. Even so, the authors of the study concluded that this was not a sufficient benefit to outweigh the substantial costs of incarcerating so many, for so long. ${ }^{17}$

More generally, studies of deterrence have consistently shown that increasing the certainty of punishment matters much more than increasing the amount of punishment when caught. This should not be a great surprise. Most people who break rules worry more about getting caught than about the severity of punishment if caught.

The other way that punishment laws can suppress crime is through incapacitation. Incapacitation reduces crime by locking up an offender who would otherwise be committing crimes. It would seem that both forms of mandatory life in California might have significant incapacitative effects. Third strikers are, almost by definition, prolific offenders, suggesting that long-term incarceration would prevent many felonies that they would otherwise commit. As for teens convicted of murder, having started criminal careers so early and with such serious violence, they would seem to have a long and violent criminal career ahead of them that might be prevented by their long-term incarceration. And given that violent crimes are disproportionately committed by a small percentage of the total number of criminal offenders, it makes sense that keeping even a small subset of violent offenders, like juvenile killers, in prison for a much longer period would have a positive effect on violent crime rates.

In fact, the incapacitative benefits of both forms of mandatory life are likely to be more modest than we might expect. Remember that our focus is on preventing crimes of violence. That is what the proponents of mandatory life sentences promised and certainly what the public that supported them expected. Therefore we want to know, how much violent crime have these laws prevented?

Until its reform in 2012, most three strikes sentences in California were given to defendants who had committed a nonviolent felony as their third strike. Most of these defendants did not have a recent history of criminal violence either. As a 
result, they were not at high risk of committing violent crimes. Most three-strikers were also relatively old when convicted, meaning their incarceration will extend through middle age and beyond, when their rate of offending is likely to decline. (Also if we take into account incarceration costs, it is worth noting that the imprisonment of older offenders is two or three times more expensive than that of younger offenders.)

One of the most basic facts of criminology (the social science of crime and criminal justice) is the age-crime curve. This shows that in virtually all eras and all jurisdictions, criminal activity peaks in the mid- to late teens. Even for offenders with a significant criminal history, criminal activity tends to decline in both frequency and severity of offense after the age of 30 . This means that long sentences for men in their 30s, 40s, 50s and beyond are much less effective in incapacitative terms than the incarceration of younger offenders who are at or near their prime offending years. The age-crime curve tells us that the predictive power of a past criminal record-its value in predicting future crimes-diminishes greatly over time, contradicting a basic premise of Three Strikes.

The incapacitative benefits of a life sentence for juvenile murderers are also likely to be more modest than we might expect. Incapacitation means simply the prevention of crime in society during the length of a prisoner's incarceration. While by definition the juvenile sentenced to life was involved in at least one fatal, criminal incident, this does not by itself establish lifetime dangerousness. The murder conviction, by itself, does not tell us whether the individual has a history of violent behavior or how he may rank on a scale of psychopathy. Both a history of violence and an assessment of psychopathy are more reliable indicators of future violence than a single conviction. In some cases, the juvenile's involvement in homicide may be due to associations and situations that are unlikely to recur in his life.

Perhaps most important, juvenile offenders are young. Obviously. They are still growing up. It can be very hard to predict adult behavior from the acts of a 14- or 15-, 16- or 17-year-old. Finally, as noted before, the age-crime curve predicts that most offenders in this age group will desist from serious criminal activity by their mid-20s or early 30s, meaning that the rest of their life term will provide less of an incapacitation benefit.

For all this, it is likely that mandatory life laws did have some positive effect on rates of criminal violence in California. The broad increase in incarceration of persons involved in serious crime would have to have had some incapacitative effects and some additional deterrent effects. These laws got everyone's attention. The question is whether these effects were enough to justify the laws.

Even taking a purely deterrent view of punishment, harsh sentences are not justified unless they are the least severe option that will produce the most 
law-obedience. Almost all criminal justice experts maintain that there are more effective ways to achieve the same amount of violent crime suppression (or more) with sentencing laws that allow sentencer discretion. Using the money spent on additional incarceration to improve post-release programs for paroled prisoners or adding additional police on the streets or improving the quality of police investigations would likely have produced more public safety benefits.

In any event, crime prevention alone cannot justify incarceration. If it could, we would allow police to detain anyone they thought dangerous. We do not give them this power because it would violate our basic conception of justice. And that, fundamentally, is the problem with mandatory life sentences. They are in some instances clearly unjust.

\section{Three Strikes in Practice: Justice Considerations}

California voters approved Three Strikes largely because of its promise to keep people like Richard Allen Davis in prison. Voters did not want someone with a long criminal history, with two new kidnapping convictions and every sign of being a person dedicated to the worst kind of violent wrongdoing, to receive a sentence of 14 years that only kept him locked up for 8 years because of good time credits. Davis was someone who had proven, over and over, that he belonged in prison.

As noted before, though, the majority of offenders who received three strikes sentences looked nothing like Davis. Until the 2012 reform of the law, most third strike life sentences were given for nonviolent offenses, generally nonviolent drug and property crimes. ${ }^{18}$ This raises questions of both politics and justice.

How could it be that in modern California, life sentences would be meted out to nonviolent offenders? One answer is a failure of democracy. Voters simply did not realize the breadth of the law that they approved at the ballot box. Politicians did not care about the law's overbreadth because they knew they would only suffer politically if they appeared soft on crime. But we also need to consider the emotive appeal of harsh punishments for any repeat felony offender.

Because of their sheer persistence in offending, those who received third strike sentences for nonviolent offenses are among the most annoying offenders to police, prosecutors and judges. They are the Not you again defendants. Their crimes may not be major, but there are so many of them! As Three Strikes proponents sometimes said, these offenders were already doing "life on the installment plan," because their crimes so frequently landed them in jail or prison.

If punishment is conceived as a painful lesson for a past wrong and if the pain is ratcheted up for each lesson not learned, then eventually even a relatively small offense should bring a significant penalty. ${ }^{19}$ Criminal record matters. The individual 
background of the offender should as well, though. Nonviolent three strike offenders almost always have a serious substance abuse problem linked to a history of trauma and significant mental illness. They are almost always broken in some basic way. They are people for whom substance abuse and mental health treatment are far more likely to produce a change in behavior than long-term incarceration, which can exacerbate mental and emotional problems.

Finally, three-strikers are not generally among the worst of drug and property offenders. The offenders who do the most harm are those who deal drugs or commit property offenses without getting caught much. They are good at crime. That does not describe most third strike prisoners convicted of nonviolent offenses. This cohort of offenders may break the criminal law with regularity, but they also get caught with regularity. Whatever wrongdoing they engage in, these individuals rarely get away with it for long. ${ }^{20}$

\section{Juvenile Life in Practice: Justice Considerations}

The justice problems with Three Strikes were well known from the earliest days of its implementation. A life sentence for snatching a child's pizza and similar cases became headline news in California and around the world. The disparity between the offense of conviction and the sentence rendered was guaranteed to attract attention. The justice problems with mandatory life for juveniles, however, were less immediately apparent. These young people had been convicted of murder, usually first-degree murder. To brutally kill at such a young age (which is certainly what most would assume that a first-degree murder signals), suggests someone who needs to be in prison for a long time. Even for life. It is only when we look at the details of defendant lives and offenses that the injustice of mandatory life sentences here becomes apparent.

In January of 2008, Human Rights Watch published a study of juveniles sentenced to life without chance of parole in California. ${ }^{21}$ It documented a number of surprising facts about youth under the age of 18 who had been given a sentence to die in prison. (Life without chance of parole mandates an entire life spent in prison; the only possibility for relief is a pardon by the Governor, which for many years was exceedingly rare.) Youth serving such sentences were often accomplices in the murder offense and not the actual killer. The offenses were often committed with adult crime partners, who then received lower sentences than the juvenile. LWOP sentences were given in disproportionate numbers to African American and Latino youth. While there is racial disproportion in the commission of violent offenses (African-American and Latino youth in California do commit more violent offenses than White and Asian youth do), the racial 
disproportion in LWOP sentences was significantly greater than the racial disproportion found in arrest rates.

Part of the explanation for these patterns of punishment can be traced to the particular challenges of representing juvenile offenders. A large number of youth charged with these offenses have experienced severe trauma in their lives and suffer from significant mental or emotional problems which attorneys who handle adult criminal cases are not well-equipped to understand or appreciate. Most charged with these offenses are boys who are not good at expressing themselves with adults, and have, almost by definition, virtually no experience with the adult criminal justice system. They often do not understand the advice their lawyers give.

Vance Webster was 16 when he faced a murder charge. More than 20 years later, looking back, he explained his relationship with his lawyer this way: "I used to sit there [while my lawyer talked to me] saying 'yes, yes, yes' ... [even] though what he said was going in Chinese and coming out Japanese, and I don't understand either one of those languages."22

Juvenile defendants are not great legal strategists. But then how many 16- or 17-year-olds are equipped to make a sound decision about whether to take a plea offer that will lead to a long prison sentence? How can any teenager imagine that accepting 15 or 20 years in prison is a good deal when the teen did not even pull the trigger on the fatal shot? (Under the doctrine of felony murder, a person who helps in the commission of a felony such as robbery, can be guilty of murder if someone is killed during the felony.) Young defendants, even more than adults, are likely to engage in denial. Again, Vance Webster explains: "I didn't understand a lot of what my lawyer was saying. He did say, 'you're going to spend the rest of your life in prison' [if you don't take this plea deal.] As a kid, though, you tend to think, 'no, this is impossible ...' I kept thinking, you can't give me life." 23

The injustice of mandatory juvenile life sentences is largely hidden from public view because the transformation of the immature teenager to a mature adult occurs in prison. As most young people eventually do, juvenile offenders grow up. They mature. In their 20 s, most finally comprehend what they have done. They grasp the reality of the sentence that they must serve in a way they may not have before. They reconsider the gang life, if they have been gang-involved. Some find religion, or other sources of meaning. Not all decide to change their lives, but some do. And likely more would, if given more reason to change. A life prison term presents a certain disincentive to self-transformation. What's the point? many ask.

The failure to consider how the person punished might change is the worst form of moral disregard in mandatory life sentences for juveniles. 


\section{A Moderating Trend}

California today is not the same state that it was 15 or 20 years ago. Violent crime has dropped to levels not seen since the 1960s. Punishment laws have begun to reflect this drop. In 2012, voters enacted Proposition 36 which, with a few exceptions, requires that the third strike offense must be serious or violent to trigger a life sentence. ${ }^{24}$ Even before this, the California Supreme Court had given trial courts a limited ability to avoid third strike sentences by permitting them to "strike a strike" if a life sentence in the case would not be "in the spirit" of the Three Strikes law. ${ }^{25}$ Most important, by the first decade of the 21st century, elected prosecutors in the state's most populous jurisdictions had instituted office-wide policies not to seek life sentences except where the third strike was violent or the offender's record indicated particular dangerousness. $^{26}$

Meanwhile inroads on mandatory life for juveniles have been made both in court decisions and the Legislature. The United States Supreme Court has held that a mandatory sentence of life without chance of parole is unconstitutional (cruel and unusual) for a juvenile convicted of murder. ${ }^{27}$ (See Chapter 4 for more on this.) The decision has prompted California's courts to review sentences for long terms beyond a youth's life expectancy that arose from mandatory sentencing provisions. $^{28}$ The California Legislature has passed two laws permitting reconsideration of life sentences for juveniles: one permits judicial reconsideration of an LWOP sentence (the judge may reduce life without parole to 25 years to life) and another provides for parole board review of long sentences after a convicted juvenile has served at least ten years of incarceration. ${ }^{29}$

The extent of these changes should not be exaggerated, though. Three strikes sentences given for nonviolent offenses may now be reconsidered, but sentence reduction is far from certain. The original sentence still carries great weight. The same is true for review of juvenile life sentences. Also we should note that unlike Three Strikes, the laws that provide for life sentences for juveniles tried and convicted as adults remain in force, although their actual severity has been lessened by legislative changes in eligibility for parole. ${ }^{30}$

\section{Learning from the Past, Part I: Legislating Disregard with Mandatory Life}

The mandatory life sentences described in this chapter mandated disregard for the person of the punished, in violation of the cruelty rule I proposed in Chapter 4. Disregard in punishment stemmed from the decision of voters and elected officials 
to take on the role normally reserved for trial court judges. They became what I call legislative sentencers. Supporters enacted laws governing the punishment of particular offenses-a standard part of democratic governance-but instead of allowing judges to fit individual sentences to individual defendants and cases, voters and legislators dictated sentence. They sent those convicted to prison for life, sight unseen. By enacting such laws, the most important punishment decision in many cases was rendered long before the sentencing judge was even assigned the case.

To understand what happens with legislative sentencing, imagine what legislators normally do in setting the parameters (usually the upper bounds) of punishment for particular offenses. Legislators try to imagine the particulars of future offenses and offenders who will be subject to the law. This imaginative exercise naturally inclines the mind to the worst in offenses and offenders.

When we contemplate crimes in the abstract, we imagine the most culpable and the most dangerous. If the crime is first-degree murder, we imagine a highly premeditated, vicious killing committed by the most morally aware killer, someone very much like the bad guy in a crime thriller. A repeat felon subject to a three strikes law? We imagine a persistent, violent, and thoroughly unrepentant offender like Richard Allen Davis - who of course inspired many Californians to support the Three Strikes law. Because legislators consider crime in the abstract in passing punishment statutes, they customarily set high maximum penalties. They want to make sure that the worst offenders receive the punishment they deserve. It's still up to the sentencing judge to decide if the defendant standing before the court is the one who merits the maximum allowed by law, however.

The difference between the legislative and judicial role in sentencing is well illustrated by media accounts of criminal cases in the courts. Many times the media, in reporting the issuance of criminal charges, recites the maximum sentence that the person faces under law. (Law enforcement likes to highlight this figure.) Especially with nonviolent offenses, this is likely to be a misleading estimate, though, because in most instances the judge following conviction will impose a much lower penalty based on an individualized assessment of offense and offender. Assuming of course that the judge has the legal authority to order a lesser sentence. ${ }^{31}$

The tendency to imagine the worst offenses and offenders in setting statutory punishment levels is not a problem if judicial sentencers have the authority- the discretion-to impose lesser punishments based on the facts of the case. If the judge determines that the particular offense is not the worst imaginable and the offender not the most dangerous or the most culpable, then a lesser penalty may be imposed. If the penalty is mandatory, however, then the risk of excessive punishment in particular cases rises dramatically. Indeed, it becomes virtually inevitable. 
Legislative sentencing dilutes personal responsibility for punishment decisions. In traditional sentencing, an individual trial judge must decide a defendant's fate. This is a grave responsibility and those who take it seriously should be respected for bearing its moral burden. Mandatory sentences by contrast disperse responsibility for punishment. Those approving the punishments - voters or legislators-need never encounter the punished, while judges who sentence can honestly say they had little or nothing to do with the sentence imposed. It really is not their decision. As a result, no identifiable person need carry the moral weight of taking another person's liberty for life.

Legislative sentencing operates to impede sentencer empathy for the punished. This is by design. Proponents of mandatory sentences wanted punishment to be certain and severe; they understood that sentencer empathy for individual defendants would undercut these goals by encouraging lesser sentences in some cases. Legislative sentencing blocks the empathic impulse by requiring that the critical sentencing decision be made without seeing the person to be punished.

We know as a matter of human nature that it is easier to condemn persons at a distance than face-to-face. On the Internet, ordinary people hurl extraordinary vitriol at others they have never met, using words they would never speak to another person, in person, because in the virtual world their targets are mostly faceless and nameless. The same dynamic applies to punishment. It is much easier to condemn someone to life in prison when the person condemned has neither name nor face, and the decision can be rendered from a great distance in space and time.

In mandating life penalties, California voters effectively sentenced persons to severe punishment without knowing the particulars of their offenses, without seeing their uniqueness as individuals or their potential for good. It mandated a form of moral disregard.

\section{What We See-and What We Choose Not to See: A Case Study}

What we see and what we hear depends greatly on what we choose to see and hear. The eyes and the ears do not perceive on their own; they require the direction of the mind to collect and process sensory information. In Chapter 2 I noted how doing right or wrong depends on how much we try to perceive morally relevant information. It depends on our moral interest. The same dynamic applies to sentencing. To do it right requires moral interest in defendants as well as victims.

To appreciate how much we lose by donning legal blinders and sentencing legislatively, it may help to examine at least one case in more detail. And so I offer the case of Christian Bracamontes, sentenced to a life term for a crime committed at 16 . 
I met Arturo Bracamontes, Christian's father, in 2011. Arturo was perhaps in his late 40 s or early 50 s at the time. We met because his son was doing life without chance of parole in a California prison on a conviction for first-degree murder. Christian had been locked up since he was 16 years old. This is why.

Christian was out with a friend one day, tagging (painting graffiti) on a wash, a concrete gully built for flood control. Christian and his friend were approached by some other young men, one of whom offered to sell them marijuana. They said no. A little later, when they were alone again, Christian's friend suggested to him that they rob the dealer of his drugs. Christian said okay. His friend then showed him for the first time the gun he had in his backpack. Together they approached the dealer.

Displaying his gun, the friend demanded the other's marijuana. The dealer refused. In fact he dared his would-be robber to shoot, warning him that unless he did, he (the dealer) would run the two boys down and kill them. At this point, Christian figured that their bluff had been called, and he turned to pick up his bicycle to ride away. But his friend, having been dared, and with the gun in his hand, would not back down. After a countdown he shot and killed the other young man.

Christian was later arrested and charged with first-degree murder: acting as an accomplice to a felony murder, the felony being robbery. He was offered a deal. If he pled guilty to murder, he would serve a minimum of 16 years in prison and then be eligible for parole. Christian refused, believing that he had not done anything that could be called murder. Christian's parents were Spanish speakers and recent immigrants to the United States; they did not understand the legal process. There was a trial and Christian was convicted. Then the judge sentenced him to LWOP: life in prison without chance of parole. (The only other sentencing option was 25 years to life.) The friend with the gun - and actual shooter-received a lesser sentence because he took the prosecution's plea offer. ${ }^{32}$

Arturo told me that he had done everything he could to pay for lawyers to fight his son's case on appeal, to no avail. At the time we were in Sacramento to work for legislation, eventually enacted, that would give his son at least a possibility of future release.

Arturo described his son as a boy who was "muy callado," meaning very quiet, and a follower. Because of this, he said he and his wife had been very protective of him, and did not want to let him go out of the house. His eyes welling up, Arturo said that maybe they were too protective of him, that perhaps this was why he got caught up in such a bad situation and didn't know how to handle it. If they had been less protective maybe ... His voice trailed off.

Offenses and offenders like this do not fit the picture of predatory criminals offered by the advocates of mandatory life. When ordinary citizens-those without 
much contact with the criminal justice system-hear of such cases, they often think there must be some mistake in the telling. There must be some reason why such severe sentences were meted out. And there is, but it is not a good reason. They stem from the failure, or more accurately the refusal, to see the true nature of another human being. This is a failure of the public in enacting these laws and the failure of legal actors, including prosecutors, judges and sometimes defense attorneys, in applying them. These are cases in which individuals are seen only as dangerous Criminals because of the offense of conviction and, I suspect, because their class and race backgrounds make them seem unworthy of mercy.

\section{Learning from the Past, Part 2: The Politics of Criminal Punishment}

Demagogic politics and a cynical media have often been blamed for the unprecedented increase in imprisonment that occurred in the United States during the late 20th century. Critics have pointed out, accurately, that measures like Three Strikes and mandatory life penalties for juvenile offenders were enacted in a highly emotional atmosphere in which politicians and media both — each in their own way and for their own purposes - played on public fear and anger by focusing on sensational but highly unusual and largely unrepresentative criminal cases in which sympathy for victims was especially strong. This led voters to support extreme laws whose consequences they did not fully understand.

Some critics have argued that this reveals a fundamental problem with the way we formulate criminal justice policy in the United States today. ${ }^{33}$ We make it personal and emotional; we see it as a subject for highly partisan political debate. But to develop sound criminal justice policy requires careful, dispassionate study by experts and bipartisan discussion. The argument is that it makes no more sense to sentence by popular vote than it would for the Federal Reserve to set national monetary policy by opinion poll. Or to put this another way, we need to resolve punishment questions more with the head and less with the heart.

As an academic I am sympathetic to this argument, but as a citizen I am skeptical. Telling someone who is deeply upset to calm down and listen to the experts does not sound like an effective strategy in either personal life or politics. It sounds disrespectful. Lower crime rates today mean that public discussions about punishment policy are less impassioned than they were 20 years ago, but to the extent that feelings of hurt from widespread criminal violence linger-and they do - then any significant reform effort requires addressing these feelings directly. An emotional problem requires an emotional response. And for this, criminal justice experts are poorly equipped. Academics trained in law and criminology - the most likely experts to be consulted in punishment policy-are committed to the dispassionate 
study of criminal justice. They strive to illuminate the reality of crime and punishment in numbers and rules. They are likely to see public emotion as the fundamental problem rather than part of the solution.

The story of mandatory life in California raises tough moral and emotional questions: how do we respond to those most hurt by criminal violence? What call do they have on our attention? What say should they have on punishment decisions?

The cries of the hurt, which found more powerful voice in the late 20th century than perhaps ever before, presented Americans with a series of moral challenges. They accused: you did not keep us safe. You let terrible harm come to our children. Shame on you. They warned: be afraid, be very afraid, for you could be next. Look at what happened to us. And, finally, they raged: no, I will not speak nicely. I will speak my truth. What was done to us was evil and evildoers must be crushed. We must put these animals in cages, where they belong.

Politicians, the media, and others were often cowed by their fierce voices. Leaders had no answer except acquiescence. Yes, okay, we will do everything we can so that this will not happen again. Whatever else may occur, repeat offenders like those who hurt your children will not endanger you. We will keep juveniles who kill or threaten death in prison for a very, very long time. From these human threats you will be safe- or at least much safer than before. Okay? Perhaps this will give you some closure.

This was not an adequate response. In Chapters 7 and 8 I will argue that the emphasis in recent years on helping victims by punishing offenders has distracted from addressing victims' deepest needs. My concern here, though, is with the justice of the punishment ordered.

The fatal flaw- the fatal moral and emotional flaw-in the public dialogue about punishment that gave rise to mandatory life sentences is that it depended on the kind of good guys v. bad guys morality I condemned in Chapter 3. There was no room for considering the humanity of the punished. Apparently their humanity was erased by the fact of their conviction.

Victims of violence have a powerful claim on our moral attention. We must listen to victims as part of caring for them and we should listen to them because they have much to teach us about good and evil. Their calls to action, including punishment, should be taken seriously, but here independent judgment is required. Pain may bring insight. Suffering may open us to others' suffering. But it may also harden the heart. No matter how innocent the victim, no matter how guilty the wrongdoer, the victim's pain does not necessarily make the offender's punishment right.

Sometimes we must have the moral courage to disagree with victims about punishment. Punishment decisions should never deny or avoid the evil which 
victims have faced. Nor should we shirk the social guilt that is properly ours, for having failed a basic task of community which is to keep its members, especially its most vulnerable members, safe from the worst of human harms.

\section{Conclusion}

When I die, that's when they'll send me home.

Charles T., serving life without chance of parole for a crime committed when he was under 18

Coming out of the Barry J. Neidorf Juvenile Hall in Sylmar, California in the early evening, the last of the day's light still held in the sky above the mountains to the north and the night's cool yet to descend, we headed to the dark parking structure where our car waited and it struck me suddenly and hard what the boys we had just spent the last hour and a half with faced. What it meant, that they faced life in prison.

The boys, 16 and 17 years old, black and brown, who were impulsive and giddy, cautious and curious, quick to anger and yet also sensitive, shut down and open, selfish and generous - they were all of these different things in their different persons and quicksilver moods - these kids faced a journey into California's adult prisons that threatened to take most or even all of the lives they had just begun. For some reason it hit me then that they faced life inside and that this was exactly what the people of California wanted.

I understood why. They were gang members most of them, many charged with murder as either perpetrators or accomplices. Most would be convicted by guilty plea or trial in accord with modern due process. They then would appear before a judge to be sentenced by a law interested only in their crimes. They would face a law that declares, if you do the crime, you do the time, no matter your age or personal history. First-degree murder $=$ life imprisonment. How do you defeat that equation?

My wife, a licensed clinical social worker, and I in my volunteer chaplain role had begun a program which we called Strong and Free Inside for those in the Compound at Sylmar, where juvenile boys in Los Angeles County being tried as adults are held. The program combined emotional skill building with spiritual exercises, discussions and a bit of music. But at that moment I was not thinking about our program but about a legal system that I knew well, or thought I did. Except now I was seeing it from a different perspective, not as set out in statutes or court decisions but as a middle aged man trying to imagine an entire adult life in confinement.

I felt frustration that the public and its representatives could not see, or just would not see, what my wife and I had seen inside. As a former prosecutor I was certainly 
aware of the limits of what can be gleaned from prison visits. The kids in the Compound, in their county issued sneakers, sweat pants and white t-shirts were not as they had been in their neighborhoods, drinking and drugging, all "G'd up" (armed), living a self- and other-destructive lifestyle. But still what we had seen was real: teenagers so enthusiastic about singing the old gospel song, $O$ Freedom, that they shouted it out at the top of their lungs and wanted to sing it over and over again, kids who missed their own families - parents and siblings and for some of them, their own children. These were young people who in many cases were still trying to comprehend what they had done to bring them to this place. None of this would be seen by the law that would determine their futures. It would be deemed irrelevant.

In this chapter I have told a very California story, but that does not make it unique to the state. A similar story could be told in many other American jurisdictions, with many similar laws, for they were very popular in the late 20th century. The point of telling the story is to make sense of it. We need to learn its lessons about justice and injustice.

Progressives have often told the story of California's mandatory life penalties as a kind of melodrama, with a venal press, cynical politicians and bigoted voters serving in the villain roles. I prefer to see this as a tragic tale: the tragedy of a people who thought they were doing justice.

Law-abiding citizens, made fearful and angry by years of rising crime and frustrated by the inefficacy of existing rules and institutions turned to extreme measures. Disinterested in details, impatient with complexity, they struck back hard at those who threatened them. Criminals became the Enemy that had to be defeated. Safety and justice demanded their near-permanent exile. Looking back, we may feel the same sense of awful inevitability that comes from watching a classic tragedy unfold on stage or screen.

But tragedy does not excuse. We do not excuse offenders for violent wrongdoing that may be traced to what they suffered as children. Nor are we, the lawabiding, excused for wrongs that we do, even if these were prompted by the wrongs of others.

\section{Notes}

1 California Attorney General, Crime in California 2012, Table 2, p. 6.

2 California Department of Corrections and Rehabilitation, California Prisoners and Parolees, 1993-94, Table 6, p. 35. To put the 1966 California incarceration rate of 144.5 in perspective, in 1972 the national incarceration rate was 161 persons per 100,000. National Research Council, Jeremy Travis, Bruce Western \& Steve Redburn eds., The Growth of Incarceration in the United States: Exploring Causes and Consequences (Washington, D.C.: National Academies Press, 2014), p. 33. 
3 California Department of Corrections and Rehabilitation, California Prisoners and Parolees, 1993-94, Table 6, p. 35

4 If qualified as a state constitutional amendment and passed by a majority of those voting in the election, the new law could not be altered without either a two-thirds vote of both the state's Assembly and Senate or the passage of another Proposition.

5 Joshua Page, The Toughest Beat: Politics, Punishment, and the Prison Officers Union in California (New York: Oxford University Press, 2011), pp. 117-36, 201-3 on the role of the CCPOA, the prison officers' union, in the success or failure of crime and punishment related propositions in California. See pp. 117-36, on the political alliance forged between the prison officers' union and victim groups that took a hard line on criminal punishment.

6 Calif. Pen. Code sec. 190 (a). Also in 1978, the passage of Proposition 13 fundamentally changed the tax structure of California by limiting the ability of the legislature and local government to raise property and other taxes. See Jack Citrin \& William Martin eds., After the Tax Revolt: California's Proposition 13 Turns 30 (Berkeley, CA: Institute of Governmental Studies, 2009).

7 California Ballot Proposition 7 (1978), p. 34, found at https://repository.uchastings. edu/cgi/viewcontent.cgi?article=1839\&context=ca_ballot_props

8 For example, in the pamphlet provided to California voters, the Argument in Favor of 115 began: "YOUR MOST BASIC RIGHT AS AN AMERICAN IS TO BE SAFE FROM VIOLENCE AND FREE FROM FEAR." Criminal Law, California Proposition 115 (1990), found at http://repository.uhastings.edu/ca_ballots_props/1020.

9 For an in-depth look at the media's role in America's understanding of violent crime and how this may have driven public support for punitive justice policies, see Sara Sun Beale, The News Media's Influence on Criminal Justice Policy: How Market-Driven News Promotes Punitiveness, 48 Wm. and Mary L. Rev. 397 (2006). The American public generally perceives crime rates to be much higher than they actually are, perhaps because of the emphasis on dramatic instances of violence which dominate media coverage. See Lauren-Brooke Eisen \& Oliver Roeder, America's Faulty Perception of Crime Rates, Brennan Center for Justice, March 16, 2015, found at https://www.brennancenter.org/ blog/americas-faulty-perception-crime-rates.

10 For largely critical accounts of the enactment of Three Strikes, see Franklin E. Zimring, Gordon Hawkins \& Sam Kanin, Punishment and Democracy: Three Strikes and You're Out in California (Oxford: Oxford University Press, 2001); Joe Domanick, Cruel Justice: Three Strikes and the Politics of Crime in America's Golden State (Berkeley, CA: University of California Press, 2004); Michael Vitiello, Three Strikes: Can We Return to Rationality? 87 J. Crim. L. \& Criminol. 395 (1997). For a supportive account, see Mike Reynolds, Bill Jones and Dan Evans, Three Strikes and You're Out!: A Promise to Kimber (Fresno, CA: Quill Driver Books, 1996).

11 Vitiello (1997), p. 50.

12 Vitiello (1997), pp. 55-6.

13 See Jeffrey Toobin, The Man Who Kept Going Free, The New Yorker, March 7, 1994.

14 The grandfather of Polly Klaas, Joe Klaas, and her father, later came to regret their initial public support for the harsh version of Three Strikes that was passed by the 
legislature and then was adopted as part of the California constitution through the initiative process. Joe Klaas became an outspoken public opponent of the Three Strikes law. See Domanick (2004), pp. 132-41, 243-5.

15 Argument in Favor of Proposition 184, California Ballot Propositions and Ballot Initiatives, U.C. Hastings Scholarship Repository; Increased Sentences. Repeat Offenders (Three Strikes) California Proposition 184 (1994) found at http://repository.uha stings.edu/ca_ballot_props/1101.

16 California Secretary of State, Proposition 21.

17 Eric Helland \& Alexander Tabarok, Does three strikes deter? A nonparametic estimation, 42 J. Human Resources (Feb., 2007). A 2005 report by California's nonpartisan Legislative Analyst's Office was unable to determine what impact, if any, the Three Strikes law had on public safety in California. A Primer: Three Strike-The Impact After More than a Decade, October 2005, pp. 10-11. The National Research Council's conclusion on the crime-prevention effects of long-term incarceration nationwide is relevant here as well: "the evidence base demonstrates that lengthy prison sentences are ineffective as a crime control measure. Specifically, the incremental deterrent effect of increases in lengthy prison sentences is modest at best." National Research Council (2014), p. 155. In general, criminal activity is the product of so many different factors that it is extremely difficult to separate out the effects of any particular law, program or policy.

18 See Joshua E. Bowers, "The Integrity of the Game is Everything": The Problem of Geographic Disparity in Three Strikes, 76 N.Y.U. L. 1164 (2001); Legislative Analyst's Office (2005), p. 5.

19 Ewing v. California, 538 U.S. 11 (2003); Lockyer v. Andrade, 538 U.S. 63 (2003).

20 Another significant justice consideration is the way that the Three Strikes law changes the dynamics of plea-bargaining. Even if a third strike charge is not formally brought, the threat that a prosecutor may bring it can force a defendant to accept a plea to a charge that he may believe unmerited or a sentence that he believes excessive. Such a defendant may not be willing to gamble the rest of his life on the outcome of trial.

21 Human Rights Watch, "When I Die, They'll Send Me Home": Youth Sentenced to Life without Parole in California (2008), found at https://www.hrw.org/reports/2008/ us0108/.

22 Human Rights Watch "When I Die, They'll Send Me Home": Youth Sentenced to Life without Parole in California, An Update (2012), p. 21, found at https://www. hrw.org/report/2012/03/01/when-i-dietheyll-send-me-home/youth-sentenced-life-p rison-without-parole.

23 Human Rights Watch (2012), p. 18.

24 See People v. Valencia, 3 Cal. 5th 347, 350-51 (2017). Proposition 36 also permitted resentencing in cases where a life sentence was imposed for a third strike offense that was neither serious or violent. Id.

25 People v. Superior Court (Romero), 13 Cal.4th 497 (1996). See Michael Vitiello, "Three Strikes" and the Romero Case: The Supreme Court Restores Democracy, 30 Loy. L.A. L. Rev. 1643 (1997).

26 See Bowers (2001), p. 1170.

27 Miller v. Alabama, 567 U.S. 460 (2012).

28 See People v. Caballero, 55 Cal. 4th 262 (2012). 
29 The texts of the laws that were known, respectively, as SB 9 and SB 260 can be found at www.fairsentencingforyouth.org. In related developments, California voters passed Proposition 47 in November 2014, which changed a number of nonviolent and nonserious (defined by statute) felonies to misdemeanors and allowed resentencing in affected cases. In November 2016, voters passed Proposition 57, The Public Safety and Rehabilitation Act of 2016. This law increased parole eligibility for offenders convicted of nonviolent offenses. It also eliminated prosecutorial authority to file certain cases against juveniles directly in adult court, without judicial review. See Jazmine Ulloa, A new era of discretion for state's parole board, Los Angeles Times, July 27, 2017.

30 Increased eligibility of juvenile offenders for parole was accomplished by SB 260, passed in 2013. See California Legislative Information, Senate Bill 260 http://leginfo. legislature.ca.gov/faces/billNavClient.xhtml?bill_id=201320140SB260.

31 The same distinction between punishment considered in the abstract, meaning legislatively, and in the context of a particular case, as sentencing judges normally do, is demonstrated by studies of public views of punishment in the United States and throughout the developed world. These studies consistently show that many believe that sentences currently meted out are too low. Judges need to get tougher on crime. Yet the same individuals when asked how they would sentence in particular cases, choose sentences similar to or even more lenient than those usually given by judges in the jurisdiction. Sentencing in particular cases is very different than sentencing in the abstract. See Rachel E. Barkow, Administering Crime, 52 UCLA L. Rev. 715, 750-2 (2005).

32 See Paige St. John, Some Juvenile Killers Would Get Parole If Jerry Brown Signs Bill, Los Angeles Times, Sept. 21, 2012; Marisa Lagos, Bill Would Let Some Inmates Appeal Lifetime Terms, San Francisco Chronicle, Aug. 17, 2011. The case serves as an excellent example of the way that guilty plea negotiations can produce arbitrary results. The theory behind modern plea negotiation is that the free-market give-and-take between prosecutors and defense attorneys, in consultation with their clients, will produce just results in a pragmatic and efficient way. Enormous variations in the abilities of the attorneys involved, their understanding of the facts, based on only preliminary investigations, the coercive power of potential penalties and the judgment of defendants all contribute to a great deal of arbitrariness in results.

33 See Zimring, et al. (2001). 


\section{OUR PRISONS, OUR PRISONERS}

\section{Cruelty in Penal Practice}

I go home today knowing I saved that child molester from that serial killer. And that pretty much describes the job satisfaction we get. ${ }^{1}$

Joke told by correctional officers in California

It's called the CDCR: the California Department of Corrections and Rehabilitation. But the $\mathrm{R}$ is silent.

Joke told by prisoners about the California prison system

Imagine a society in which the losers really lose. They aren't just voted off the island as in some TV reality show to return to ordinary, untelevised life; they are removed from society entirely. They are banned.

Imagine a society constructed on the model of the English Premier League. In this league, which has some of the world's best football teams (Americans read here soccer), at the end of the season the worst teams in the year's competition are relegated to the next lower division (called the Champion's League) while the highest-ranked teams in the lower division are elevated to the Premier League. A similar system is used throughout European professional football. Competition during the season determines inclusion or exclusion in the league at season's end.

Incarceration in the United States works a little like this. The worst off in society - the worst social and economic performers, if you prefer-are the most likely to go to prison. The poor, the ill-educated, the most traumatized, the mentally ill; disproportionately men and women of color: these are the distinctive characteristics of those incarcerated in America. 
Of course men and women do not go to prison for losing a social or economic competition or just because of trauma or disadvantage; they go to prison as punishment for violating fundamental rules of social conduct. Still the analogy illustrates important features of the relationship between punisher and punished. Having such clear losers in society makes everyone else a kind of winner. Perhaps this is why (or partly why) the United States, one of the most competitive societies on earth, uses incarceration more than any other nation, and why the increase in incarceration in the late 20th century coincided with heightened social and economic competition between individuals and groups. The analogy illustrates the attraction of an institution that excludes from American society those who have fallen short. Getting rid of criminals, shipping them off to distant places of isolation, promises to make free society cleaner, safer, and better for the law-abiding. And best of all, this happens by an apparently meritocratic selection process in which the losers have only themselves to blame for their fate.

In what follows I challenge this view of incarceration and the relationship between American free citizens and those locked up. Prisons and their inhabitants are the legal and moral responsibility of all Americans. The law-abiding are as responsible for prisons as are law breakers. Incarceration forges a close, albeit coercive, relationship between the state and the incarcerated, creating moral and legal obligations for those who authorize and fund prisons, namely us.

To meet our responsibilities we must look closely at both penal policy and reality. I have argued that incarceration may be justified to punish serious criminal wrongs. But what does that mean, exactly? Is the basic deprivation of liberty and separation from loved ones inherent in incarceration sufficient to accomplish its punitive ends? Some seem to believe that virtually every aspect of daily life inside a prison should be a hardship as well, so that the prisoner's experience is totally punitive. Is this justified?

What should our moral attitude be to the incarcerated? Should hostility, suspicion and disrespect characterize official relations with the punished-they are criminals after all—or should prisoners despite their status be treated with respect and some degree of concern?

The highest priority for those running prisons will always be security. Escapes must be prevented. Correctional officers, civilian staff and volunteers must be protected from violence by inmates. The promise of security should also extend to inmates. This means protection from violence by both fellow inmates and staff.

Another function of incarceration, deemphasized in recent years but still important, is providing inmates with an opportunity to change their lives. This is often called rehabilitation. For reasons I will explain, I prefer to use either an older term, reformation, or a much more basic one, change. The question is whether we are committed to helping prisoners change. 
Many ask about the efficacy of programs for prisoners, as in: do rehabilitation programs reduce recidivism? But I will ask a moral question: do we believe that those sent to prison are fully human? Many Americans consider state and federal prisoners essentially hopeless; largely incapable of positive change and definitely dangerous. Their (low) worth is determined by their criminal record. I say that prisoners are fully human and must be treated with moral regard, the same principle that justifies their incarceration.

Much of this chapter focuses on two particular problems in prison management: the use of extended solitary confinement for discipline or control and the sexual abuse of inmates. Each of these involves a form of violence, risking serious harm to body and soul. Each raises serious questions of moral regard.

To anyone familiar with incarceration in America, the limits of this chapter will be obvious. I focus on prisons and do not say much about jails and jail-type institutions such as juvenile detention halls and immigration detention facilities. (While it's true that much of what follows applies to jails, jails hold persons pending trial as well as for punishment on lesser offenses, making jails significantly different institutions from prisons.) Other important issues that I do not address include race conflicts in prison, relations between prisoners and their families on the outside and the different roles of elected officials, prison administrators, prison unions, corporations (that run for-profit facilities) and the courts in setting prison policy. To cover all that would require a book, not a chapter. The point of this chapter is to extend our conception of justice to the realities of incarceration.

\section{Public Responsibility for Life in Prison}

When a sheriff or a marshal takes a man from the courthouse in a prison van and transports him to confinement for two or three or 10 years, this is our act. We have tolled the bell for him. And whether we like it or not, we have made him our collective responsibility. We are free to do something about him; he is not. ${ }^{2}$

Many Americans believe that because prisoners are incarcerated due to their choice to offend, their penal situations are their responsibility—nothing to do with us. And yet consider the reality of prison.

Prisons are not natural institutions. They do not grow from seeds in the ground like trees or bushes. They must be built, staffed and populated. They cost large sums of money to construct and maintain. They require laws, legal judgments, large workforces and extensive bureaucracies. In a democracy, voters through their representatives authorize and fund prisons. This makes what happens to prisoners a public responsibility. 
Sending someone to prison creates a unique relationship between state and convict. The state tells prisoners where they will live and who with, what they will eat, what they can hear and see, what they can experience and not. The physical situation of prisoners, the routine of their daily lives, their medical care, their fates, depend in significant measure on legal and other decisions made by state officers acting on behalf of the American public. There are few relationships as constrained or as closely tied to state authority as that between prison inmates and their keepers. This authoritarian relationship extends to the families and communities of prisoners, for their only access to the prisoner is through the prison authority.

For all this, we, the law-abiding, are responsible.

\section{Who Goes to Prison?}

I was in Palm Springs [California] a couple of months ago, and this woman was like, "I'm from Texas, I'm the judge in a criminal [court], and I never realized that the people I was sentencing were really people."

Laverne Cox, actor on Orange is the New Black, on the impact the television series has had on viewers' view of prisoners ${ }^{3}$

So who are these people who go to prison? One answer is legal: people convicted of serious crimes. Prisoners are defined by their offenses. This is the public's predominant view, and to a large extent the perspective of prison authorities as well. Criminal record weighs heavily in determining what facility prisoners will go to and where they will be housed in the facility. It is the predominant perspective of modern parole boards. Certainly I have emphasized the connection between crimes of violence and punishment in this book. To meet the requirements of moral regard, though, we must consider prisoners as human beings with distinct histories who will be affected in different ways by the prison experience.

Visitors entering a prison for the first time are often surprised less by the strange (everyone expects strange) than by the apparently ordinary. The basic interior features of painted concrete block walls, concrete floors and metal doors are reminiscent of schools and other hard-use public buildings. As for the inmates, while they wear prison uniforms and represent a distinct demographic - all of one sex, no children, almost no elderly and a disproportionate number of people of color-they do not otherwise appear exceptional. Prisoners do not wear signs declaring their criminal offenses. With the exception of those who have taken tattooing to extremes, their involvement in wrongdoing is not written on their faces. They are 
just people. And so, for a moment, let us consider them that way. Do they have any other notable characteristics besides their crimes of conviction? They do, and they are striking. As a group, prison inmates are predominantly males under 40, come from poverty, are poorly educated, have significant histories of trauma and drug and alcohol abuse and as a group have a high rate of mental illness.

Although the numbers of girls and women incarcerated has greatly increased in recent years, and at a quicker rate than for males, the overwhelming majority of prisoners in the United States are still male. Ninety-three percent of inmates in prisons are male; seven percent are female. ${ }^{4}$

Prison inmates are younger than the general population, with the great majority under the age of $40 .^{5}$ The number of older inmates has grown considerably, however, a direct result of the increase in life sentences given over the last 30 years.

Nationally, the majority of American prisoners are African-American or Hispanic, even though whites remain the significant majority in the general population of the US. In 2011, 38 percent of state and federal prisoners were African American, 35 percent were White and 21 percent were Hispanic. ${ }^{6}$ For a sense of how these figures compare with the general population, consider the statistical risk of incarceration by race. Comparing their numbers in the general population to those in prison, white males in America have a 6 percent chance of serving prison time at some point in their lifetime. Hispanic males have a 17 percent chance. Black males have a 32 percent chance. ${ }^{7}$ To put this in terms of incarceration rates, a measure we have employed before, in California in 2005 the rate for white adult men was 770 per 100,000; the rate for Latino adult men was 1,100 and for African American adult men was 5,125 per $100,000 .^{8}$

Those in prison are considerably less educated than those on the outside. This may be the single most important difference between prisoners and the general population because of the strong connection between education levels and poverty, health and other critical life measures. The majority of prisoners never finished high school, but in many instances their actual educational level is even lower than their highest grade completed. A representative portrait of actual educational achievement may be found in the Florida Department of Corrections' annual report of Tests of Adult Education (TABE) scores for its prisoners. The TABE assesses the person's current level of intellectual functioning. In 2011 the median grade level achieved by Florida prisoners according to the TABE was $7^{\text {th }}$ grade. Approximately 50 percent performed at a $6^{\text {th }}$ grade level or below; 39 percent scored at 5 th grade or below. Only 36 percent of prisoners demonstrated literacy skills at the level of the GED (General Educational Development test) which is set at a $9^{\text {th }}$ grade level of achievement. ${ }^{9}$ 
The incarcerated present a different profile from the general population with respect to family background. In a 2002 national survey of jail inmates, half grew up in either a single parent household or with a guardian; 31 percent in a household where a parent or guardian abused drugs or alcohol. Twelve percent grew up as wards of the state in foster care or in the care of an agency or institution. Eighteen percent reported having been physically or sexually abused in the past: 13 percent of male inmates and 55 percent of female inmates.

The incarcerated are much more likely than others to have friends and family who have been incarcerated. In California, 58 percent of women in prison had an immediate family member who has been imprisoned; 42 percent of male prisoners had an immediate family member who is or was incarcerated..$^{10}$ A national survey of jail inmates revealed similar numbers: 31 percent of those in jail had a brother, 19 percent a father, 9 percent a sister and 7 percent a mother who had been incarcerated. ${ }^{11}$

Many prisoners are parents of minor children. In 2006, two-thirds of women in California prisons had children under the age of 18 . About half of men in prison are fathers of children under $18 .^{12}$

Current estimates are that a majority of prison inmates suffer from some mental health problem. ${ }^{13}$ Estimates of serious mental health problems like bipolar disorder or schizophrenia vary considerably, with recent figures ranging from 10 percent of prisoners to 25 percent. Even at the lower figure, this is double the rate in the general population. ${ }^{14}$

Rates of substance abuse for prisoners are also much higher than in the general population; a majority of prison inmates report a substance abuse problem. The rate in the general population is 9 percent. $^{15}$

Finally, those sent to prison come disproportionately from poverty. A very rough measure of the poverty-crime-incarceration connection comes from the use of court appointed counsel for the indigent. In 1997, 73 percent of those sent to prison had been represented by court appointed counsel. ${ }^{16}$ Incarceration also works to the serious and often permanent economic disadvantage of prisoners after they are released. Prison does not look good on your resume, to understate the matter considerably. It also erases critical years that could have been used to develop the skills and relationships needed for success in the world. ${ }^{17}$

This portrait of the incarcerated reveals the enormous personal and social disadvantages that prisoners have faced in their prior lives and will face on their release. (And the great majority will be released.) In a society that maintains that everyone can make it if they try hard enough, many of the incarcerated have had very few real chances at success. This truth needs to be respected along with the truth of their wrongdoing. 


\section{The Purposes of Incarceration}

Punishment is suffering inflicted on the criminal for the wrong done by him, with a special view to secure his reformation ... [T] he supreme aim of prison discipline is the reformation of criminals, not the infliction of vindictive suffering.

Declaration of Principles Adopted and Promulgated by the 1870 Congress

of the National Prison Association

The Legislature finds and declares that the purpose of imprisonment for crime is punishment.

California Penal Code sec. 1170(a)(1) $(1977-2016)^{18}$

As these quotations demonstrate, the purpose of incarceration has been debated for a very long time in the United States. Three rival norms compete for dominance: punishment, security and reformation. Punishment and reformation wage the most public battle for priority, but security mostly prevails in the end.

\section{The Ideological Debate: Reformation v. Punishment}

From the late 19th century to the late 20th century, most US jurisdictions relied on a correctional system to handle those who violated the criminal law. ${ }^{19}$ For those convicted of crime, judges could choose between ordering probation for the offender, or incarceration. Probation was designed to give offenders a chance to mend their ways while still residing in the community: they could keep their jobs and live with their families, subject to the supervision of probation officers and courts. Those ordered incarcerated for crimes were given indeterminate sentences in correctional facilities (prisons) where rehabilitative programs were emphasized. The actual time that a prisoner spent in prison was ultimately determined by a parole board, based on its estimation of the inmate's progress toward social reformation. A separate juvenile delinquency system expressly designed to rehabilitate, handled juvenile offenders.

The central idea behind these institutions and practices was that, using the new sciences of criminology and penology, experts in criminal justice would devise individualized programs to modify offender character and behavior. Post conviction treatment would focus on changing the offender rather than punishing the offense.

The correctional system's official commitment to offender reformation was evidenced in many ways, including the naming of penal institutions as correctional facilities. Whether those carrying out incarceral policy ever fully committed to correctional ideals is questionable, however. The enormous discretionary powers given correctional decision-makers and institutions were often used more 
for institutional control than actual offender reformation. And the vast majority of those who worked in correctional institutions and served on parole boards lacked significant (or any) education or training in criminology, psychology or related fields as was contemplated by the original proponents of the correctional model.

In part because of the mismatch between ideals and practice, the correctional system came under harsh scrutiny by the 1970s. In the case of prisons, its ideals were largely abandoned in many jurisdictions by the end of the decade. The ideological shift was succinctly stated by the California legislature in its determinate sentencing enactment that was quoted at the beginning of this section: "The Legislature finds and declares that the purpose of imprisonment for crime is punishment." Judges were no longer to send offenders away for rehabilitation; prison was for punishment.

The new punishment philosophy sought to base incarceration on legal criteria: the offense of conviction and the offender's criminal record. Decisional authority was legal: sentencing statutes and judicial orders (sentences). In this way, legal authority supplanted the purported criminological expertise of prison authorities and parole boards.

As to how inmates were treated in prison, this was largely left to prison authorities. The result was the triumph of punishment and security interests over prisoner reformation.

Prison administrators oversaw the construction of many new facilities to handle an influx of new prisoners. This was critical to the new era of mass incarceration. Prison authorities also devised new systems of inmate management, including increased use of solitary confinement. In the late 20th century, elected officials in some jurisdictions strove to make the prison experience harsher. Variously called the "no-frills" movement (by supporters) and the "penal harm" movement (by critics), this sought the removal of prisoner privileges such as conjugal visits, individual televisions and recreation equipment, especially for weight lifting.

Meanwhile many inmate rehabilitation programs were reduced or eliminated. Without ideological support, cuts in funding were inevitable. ${ }^{20}$ In recent years, attention to offender reformation has revived among academics and activists (both liberal and conservative) who are concerned with prison policy. Not a great deal has been accomplished to change a status quo widely recognized as unsatisfactory, however. Today rehabilitative programs for inmates are unevenly distributed among the prison population according to a variety of factors, including the interest of wardens, the security level of the prison, the length of the prisoner's sentence (generally the longer the sentence, the less access to programming) and the availability of volunteers to staff educational and other programs. Volunteer availability in turn often depends on the facility's proximity to an urban area, and many prisons 
are located far from population centers. Prison programming could be significantly increased with even modest increases in public funding. The political reality is that even small increases for prison programming are hard for elected officials to support when education and other vital services for the law-abiding lack full funding. ${ }^{21}$

\section{Security Above All}

In prison, security comes first, always. Whose security, how it is measured and what it requires, are ever-contested matters, however.

We begin with some obvious facts about prison security, because they can be overlooked. Guard duty is hard duty if done well. Done badly, it is not so hard. To keep hundreds or even thousands of people confined against their will for months, years, and even lifetimes without regular resort to physical force and without allowing violence to break out between inmates is a challenge. To do this with a group that has a proven propensity for rule breaking including criminal violence, increases the difficulty. To do this with an unarmed staff that is greatly outnumbered by inmates, according to rules handed down by elected officials, bureaucrats and judges who have little or no personal experience of prison life, compounds the challenge.

But institutional security can also be achieved by darker methods, including violence. Correctional officers and prison administrators may use their powers arbitrarily, keeping inmates constantly guessing where they stand. Guards may manipulate divisions between inmates and prey on the most vulnerable, making them cautionary examples for all. In short, they may wield power in tyrannical fashion. These methods may keep prisoners in line, at least for a time. They do not constitute a moral or even lawful approach to prison security, however.

Properly understood, prison security begins with the safety of correctional officers and civilian staff. This might be considered a corollary of the oxygen mask rule on airplanes: take care of yourself before taking care of anyone else. If guards and staff are not safe, inmates will not be either. Security for staff means measures to minimize the risk of assaults, both deadly and nondeadly. The security concerns of staff go beyond this, though, to the larger question of authority. To run a prison, officials require the means to both reward good behavior and punish bad behavior. Those in charge must have some ability to compel the actions of inmates without resort to violence.

Security also includes inmate safety. What this entails in practice is a more fraught question than it is for staff. How much must inmates be protected from verbal harassment, threats or from nondeadly force attacks? What level of protection is required to keep inmates safe from sexual violence and abuse? Safeguarding inmate 
life should be the highest priority but even deadly health threats are sometimes ignored in the name of security and lack of resources. Institutional commitment to minimizing nondeadly threats to inmate safety varies widely. ${ }^{22}$

Security for inmates must include protection from unjustified staff violence, including beatings and sexual abuse. Hard data on staff abuse is difficult to obtain for many reasons. The line between justified and unjustified force will be contested in many instances. Barriers to inmate reporting of staff abuse are enormous in the closed culture of prisons, meaning that even interested senior administrators may not know of abuse when it occurs. Here again some obvious realities need to be confronted. Power tends to corrupt according to the amount of power wielded and availability of checks upon its use. Prisons score high on the former and low on the latter, making them high-risk environments for abuse. Correctional personnel have a great deal of power over inmates and while officers and staff are overseen by superior officers, administrators and the courts, these authorities are generally far removed from prison life and often do not know what occurs inside on a daily basis. One recent indication of the problem of staff abuse comes from new national confidential surveys of inmates about sexual abuse while incarcerated. These surveys consistently indicate that both male and female inmates face a greater risk of sexual abuse from staff than they do from fellow inmates. ${ }^{23}$ The problem of sexual violence will be considered later in the chapter.

And then there is the security norm that no one will openly proclaim or defend, which is the norm of institutional security. By this I do not mean concerns about the individual safety of staff or inmates, but the well-being of the prison as an institution. Human institutions seek to protect themselves from attack just as individuals and groups do. So it is that prisons and prison systems make the efficient processing of inmates and the avoidance of public controversy their highest priorities. These are key to institutional well-being in the form of funding and public repute. Prisoners should not escape or die. Staff should not be injured or killed. But above all, nothing should happen that draws negative attention to the institution.

The norm of institutional security powerfully reinforces the tendency of prisons to keep tight control over all information about the facility. As long as details about life inside do not get out, administrators and staff can act with a relatively free hand. This means that in practice, unwritten rules of conduct in prison may be as important as written rules. Inmate and staff practices that violate official policy, but seem to promote the daily smooth running of the institution may be tolerated even if they are contrary to the norms of offender reformation or punishment.

Because security is their overriding concern, correctional officers view inmates with suspicion. Just as well trained police officers are constantly on the lookout for threats to public order, so correctional officers (COs) are trained to watch 
constantly for inmate manipulation, defiance and rule violations. The presumption of COs is that inmates are always looking to break the rules and for a way to undermine $\mathrm{CO}$ control of the institution.

Correctional officers view inmates with distrust; inmates reciprocate. Correctional officers have the keys, the pepper spray and the authority to discipline; inmates have the advantage of numbers. Neither has much reason to like, or respect, the other. This does not mean that guard-inmate relations must be hostile or disrespectful, but it does limit the ability of correctional officers to engage in reformation programs. ${ }^{24}$ Successful prison programming generally depends on civilian staff and volunteers who, because they are not charged with security, can establish relationships of trust with inmates.

The other critical player in prison security is the structure itself. Architecture and technology have always been critical to prison security and dictate many features of prison life. Today surveillance cameras and electronic controls allow guards to manage the movement of prisoners with minimal direct contact between inmates and staff. This is a key component of supermax prisons and solitary confinement units in prisons.

\section{Offender Reformation}

And still, even now, a third norm competes with punishment and security for influence in incarceration policy: the reformation of offenders. Reformation, more commonly called rehabilitation, suffered a great reputational decline in the 1970s. The shift to determinate sentencing-meaning sentences set by the judge and not subject to discretionary decisions by a parole board-was driven in part by the elevation of retribution as a punishment norm. Offenders were sent to prison because they deserved punishment for the crime, not because prison would make them better citizens. Many also came to doubt the efficacy of rehabilitative programs. Sociologist Robert Martinson wrote a series of articles in 1974 entitled, "What Works?" that summarized an extensive social science review of rehabilitation programs. Martinson came to such discouraging conclusions that the shorthand for his articles became: nothing works. ${ }^{25}$ This led to the erroneous conclusion that nothing would work. In fact, there is evidence today that a variety of programs may have a positive impact on offender recidivism, including substance abuse programs, some forms of mental health therapy, educational programs and work programs.

Before taking a deeper look at the challenges and possibilities of offender change, a word about terminology. I prefer to speak of offender reformation rather than the more commonly used term, rehabilitation. Re-habilitation suggests that offenders were fully functioning, productive citizens before suffering de- 
habilitation. Rehabilitation is what a builder undertakes with a house damaged in the storm, or a physical therapist with someone recovering from surgery or a fall. But this does not describe well, even by analogy, the person in prison. The personal and social dysfunctions that lead to imprisonment are in many cases so deeply rooted that it makes no sense to try to restore the individual to an earlier state of being. The aim must be to help the inmate change his or her life direction.

Equally important, rehabilitation is based on a health norm. This is consistent with modern social science, which views physical, mental and social health as the ultimate goal of all public efforts and consciously avoids making moral judgments. But as I have maintained throughout, criminality, especially violent criminality, involves the wrong of moral disregard. We should reject violence as a means of gaining power and respect not just on grounds of personal and social well-being, but because it is wrong. The word reformation better conveys the moral dimension of needed change than does rehabilitation.

Exactly what does a commitment to offender reformation entail? Seeking offender reformation simply means that the incarcerated should have a chance to change their lives. We should not expect that any prison program will by itself change the offender, but the offender should have the opportunity to develop personal, social and work skills and values needed for a law-abiding life.

Offender reformation as a norm is important in its own right. It also serves as an important corrective to the potential excesses of punishment and security norms. Without reformation and its insistence on the humanity of inmates, incarceration can easily devolve into human warehousing, in which persons may be treated worse than animals in a zoo. ${ }^{26}$

\section{Striking a Balance}

So how do we reconcile the competing norms of punishment, security and reformation? Reconciling punishment and security is not so hard, for they generally work well together. To the extent that security measures make the life of prisoners more difficult, so much the better for punishment. It's not a holiday cruise, as correctional folks are wont to say. In recent years, the alliance of punishment and security has determined the realities of prisoner life in most institutions. But then there is offender reformation. How can incarceration be punishment and still promote offender reformation? The answer lies in a return to first principles of moral responsibility.

Imprisonment is ordered as a consequence for serious crime. It is responsibility imposed on the prisoner by society. We hope that the offender will internalize 
society's judgment about the wrongness of his conduct and accept personal responsibility for having broken the law. Reformation seeks the same result, but by a different path. Offender reformation occurs when the individual freely chooses to accept personal responsibility for harmful actions and relationships rather than just suffering the consequences of society's legal judgments.

For those who have committed violent crimes, reformation usually means turning away from what I call violence thinking: the inclination to see all slights, challenges and opposition as existential threats that require the use or threat of force to repel. Instead of seeing slights, real or perceived, as requiring a violent response, the person chooses nonviolent ways of building and maintaining self and social respect. Reformation requires developing respect for oneself and others based on moral regard, not force.

The norm of reformation should inform the management philosophy of the institution. It cannot just be about the programs that outsiders bring in. The organization of the facility must allow for personal change. If daily life for inmates in prison is brutal and survival depends on constant power calculations, manipulation and even predation, then reformation in prison becomes nearly impossible.

The dynamics of offender change will be the main subject of Chapter 9. For the rest of this chapter we will consider two particular problems with moral disregard (cruelty) in prison life: the use of solitary confinement and the prevalence of sexual violence.

\section{Penal Discipline, Control and Solitary Confinement}

In its intention, I am well convinced that it is kind, humane and meant for reformation; but I am persuaded that those who devised the system of Prison Discipline [permanent solitary confinement], and those benevolent gentleman who carry it into execution, do not know what it is that they are doing. I believe that very few men are capable of estimating the immense amount of torture and agony which this dreadful punishment, prolonged for years, inflicts upon the sufferers ... I hold this slow and daily tampering with the mysteries of the brain, to be immeasurably worse than any torture of the body: and because its ghastly signs and tokens are not so palpable to the eye and sense of touch as scars upon the flesh; because its wounds are not upon the surface, and it extorts few cries that human ears can hear; therefore I the more denounce it, as a secret punishment which slumbering humanity is not roused up to stay.

Charles Dickens, on the use of solitary confinement in Pennsylvania, $1842^{27}$

From the earliest days of the penitentiary in America, questions about proper methods for prison discipline and the use of solitary confinement have troubled 
those charged with running prisons. In the early 19th century a fierce internecine debate arose between defenders of the New York system of penitentiaries where guards could whip prisoners to enforce the institution's rule of absolute silence, and the permanent solitary confinement of prisoners in the Pennsylvania penitentiary system. $^{28}$ It was the practice of the latter that inspired Charles Dickens's quote above. Advocates for each system argued over which was more cruel-occasional whipping or constant separation-and which was more effective in achieving prisoner reformation.

New York system advocates held that extended solitary confinement was cruel as it drove prisoners crazy and did not actually reform their characters. Pennsylvania system advocates responded that holding inmates in solitary cells was not cruel but actually was good for their souls. They contended social isolation would prompt them to repent of wrongdoing. Pennsylvania system defenders called the disciplinary use of whipping in New York system penitentiaries a cruel and brutal return to primitive punishment methods of the past.

Today the debate about prison discipline and solitary confinement has changed: no one seriously advocates whipping disobedient inmates or argues that extended solitary confinement is good for the soul. The discussion today is whether severe forms of inmate isolation are needed for prison discipline and whether they can seriously harm prisoners.

Contemporary solitary confinement is very different from "the hole" of days past: a dark fetid closet of a cell into which a prisoner might be placed for days, weeks or longer as a disciplinary measure. Today solitary confinement can be found under a number of different labels, including Administrative Segregation (AdSeg), Intensive Management Unit (IMU), Restricted Housing Unit (RHU), and Secure Housing Unit (SHU). The one term that prison administrators generally avoid is solitary confinement. I use it nevertheless because it describes the essential feature of this kind of imprisonment: nearly complete physical isolation from other inmates in the prison. As I use the term, solitary confinement involves being locked in a single cell for 22-23 or more hours a day. The cell is usually about the size of a small bathroom or a parking lot space. The prisoner is normally denied any electronic media (television or radio). Books, papers and other sources of mental stimulation are significantly restricted. Prisoners are usually allowed out of their cells for between 30 and 90 minutes a day for showers or exercise, but usually without interaction with other inmates in this time. Inmates are subject to continuous surveillance by cameras. $^{29}$

In the last 30 years the use of solitary confinement has grown enormously in US prisons, jails and juvenile detention facilities. Today most facilities have a unit or wing designated for extended prisoner isolation. Some entire prisons, known as 
supermaxes, have been expressly designed and built for the confinement of prisoners in solitary.

The reasons for the increased use of solitary are many but the rationale is always security. Prison administrators came to believe that extended isolation of especially troublesome prisoners was a necessary tool for maintaining prison discipline and control.

Certainly the security challenges facing prisons in the late 20th century were many. They needed to handle more prisoners than before-way more-and this often led to overcrowding. Overcrowded conditions challenge discipline and increase the risk of serious violence. The danger of prison riots and total loss of institutional control receded by the latter part of the century, but the memory of prisoner takeovers like those of the New Mexico State penitentiary in 1980 and the Attica, New York prison in 1971 remained fresh. ${ }^{30}$

The increase in extremely long sentences and the elimination or reduction in parole grants meant that a larger percentage of prisoners had less to lose from basic rule violations in prison. They had no good time credits to forfeit or parole board to impress. Simultaneously, a decrease in rehabilitative programs meant that prisoners had fewer privileges to lose as well. Without carrots to offer, prisons had to rely more heavily on the stick for control, which increasingly meant solitary confinement.

The late 20th century also saw a significant increase in the number of severely mentally ill prisoners, largely as a result of the closing of state institutions for the mentally ill. The criminal justice system became the default mental health system for the nation. Mentally ill prisoners have difficulty managing the stress of prison life, leading to conflicts with other inmates. They also find it hard to follow facility rules, leading to conflicts with staff. Both make them prime candidates for solitary confinement. ${ }^{31}$

In some Western states a significant increase in the power of prison gangs presented a new and serious challenge to staff control of the institution. Shot callers for the prison gangs (not to be confused with street gangs that operate primarily outside prison) threatened to become de facto leaders of the inmate population, ordering violence inside and even on the outside, and directing trafficking in drugs and other contraband in facilities.

Finally, new surveillance and building technology made feasible an entirely new level of prisoner isolation. With cameras and central electronic controls, guards could monitor prisoners in their cells and direct their movements in the institution without close contact with staff or other inmates, significantly reducing the risk of violence. Long-term removal of prison gang members and leaders from the general prison population promised to give prison officials a major weapon against prison gangs. 
Essential to the rationale for the new solitary confinement is a phrase that recurs over and over again in the discussion of modern supermax units, where much of contemporary solitary confinement occurs: that the prisoners sent there are "the worst of the worst." Out of all those sent to prison, these we are told are the prisoners most likely to wreak havoc on other inmates, staff and institution based on their past behavior. Administrators argue that these are prisoners who have killed or beaten other inmates, attacked staff, attempted to escape, started riots. Or they may be leaders of prison gangs or other groups that threaten institutional control. The argument is that these inmates stand out as especially dangerous, violent and incorrigible and that they need to be isolated, potentially for long and even indefinite periods, for the safety of all.

The move to extended solitary confinement raises two questions for our purposes: (1) are those in extended solitary really the worst of the worst? and (2) what does this kind of confinement do to prisoners?

Criteria for defining the "worst of the worst" vary greatly from institution to institution and prison system to prison system. The most common criteria are repeated acts of violence by the inmate, a demonstrated escape threat, and membership in a so-called Security Threat Group, usually a prison gang. It is this last category that is the most problematic because of questions about the evidence needed to establish membership and the extent of the threat presented by the individual and group.

Critics have also argued that some inmates land in solitary confinement primarily as a result of mental illness. The seriously mentally ill are among the most difficult of prisoners. They may be disruptive to other inmates, insolent to staff, and resistant to the usual checks and balances of prison life. Some are also capable of unpredictable violence. For all these reasons they are prime candidates for solitary. But still they would not seem to qualify as the "worst of the worst" in the sense that prison administrators have used the phrase. Nor does long-term placement in isolation promise to improve the disturbed inmate's behavior in the long term.

Now to look at the effects of extended solitary confinement on prisoners. In 2011, psychologist Craig Haney summarized the impact of solitary on California prisoners this way:

$[\mathrm{P}]$ risoners in these units complain of chronic and overwhelming feelings of sadness, hopelessness, and depression. Rates of suicide in the California lockup units are by far the highest in any prison housing units anywhere in the country. Many SHU inmates become deeply and unshakably paranoid, and are profoundly anxious around and afraid of people (on those rare occasions when they are allowed contact with them). Some begin to lose their grasp on their sanity and badly decompensate. Others are certain that they will never be able 
to live normally among people again and are consumed by this fear. Many deteriorate mentally and emotionally, and their capacity to function as remotely effective, feeling, social beings atrophies. ${ }^{32}$

Here are accounts from prisoners in Massachusetts in the early 1980s about their experience in solitary confinement in the Walpole penitentiary:

The cell walls start wavering ... Melting, everything in the cell starts moving; everything gets darker and you feel you are losing your vision. ${ }^{33}$

I start to dwell on things - too many roaches-get scared one might get into my ear. Start to feel hot-extreme heat-then I can barely breathe, start sweating, heart races, can't sit still, shaking, get a headache-real bad. ${ }^{34}$

I can't concentrate, can't read ... Your mind's narcotized ... sometimes can't grasp words in my mind that I know. Get stuck, have to think of another word. Memory is going. You feel you are losing something you might not get back. ${ }^{35}$

Like any form of stress, the effects of solitary confinement depend on the individual. The mentally strong can survive long periods in solitary confinement without suffering significant harm. The more vulnerable may be psychologically damaged or destroyed by the experience, however. Unfortunately, it can be difficult to determine ahead of time who can handle this stress and who will, to use the mental health term, seriously decompensate.

Although frequently ordered as a disciplinary measure, extended isolation does not necessarily improve prisoner behavior. It can have the opposite effect. Some who have spent significant periods in solitary confinement experience almost uncontrollable rage, increasing their risk for violence on release from solitary. (Usually inmates will be released from solitary back to the general prison population, but sometimes under determinate sentencing laws, they will be released directly from solitary confinement to the free world.)

I try to sleep 16 hours a day, block out my thoughts-muscles tense- think of torturing and killing the guards-lasts a couple of hours. I can't stop it. Bothers me. Have to keep control. This makes me think I'm slipping my mind. Lay in bed too much - scare yourself with thoughts in bed. I get panicky-thoughts come back - picture throwing a guard in lime - eats away at his skin, his flesh-torture him. Try to block it out, but I can't. ${ }^{36}$ 
Human beings are social animals and, with few exceptions, need regular contact with other human beings as much as they need food, water or exercise. Extended solitary confinement leads to desocialization: the loss of social skills and social confidence. It can produce extreme anxiety about social encounters. These effects are widely understood. For example, the military has learned that because prisoners of war often are held in extreme isolation, they need a very gradual resocialization process before returning to life in free society. Under the military's reentry program for such prisoners, contact with loved ones is delayed for a time and then restricted to accommodate the released prisoner's fragile mental state. Otherwise the social experience of even a family reunion can be so overwhelming as to be intolerable.

We have seen before the way that violence can fundamentally change a person, so that a survivor emerges from the experience a different person than he or she was before. And we have seen that violence harms survivors' abilities to make and sustain close connections with others. We see the same phenomena in at least some prisoners following extended solitary confinement. This suggests that solitary confinement might be considered a form of violence, as an attack not on the body but the soul. As with all victims of violence, the question becomes whether prisoners kept for long periods in solitary confinement have the resources, personal and social, to heal from their psychic injuries. Clearly some do not.

Inmates in solitary confinement are more likely than any other prisoners to engage in deliberate self-injury, such as smashing their heads against concrete walls or cutting themselves. Such behavior is generally treated by corrections staff as a rule violation subject to disciplinary sanctions. Staff generally consider such conduct to be manipulative. ${ }^{37}$ Self-harm sometimes goes further. Inmates in solitary confinement consistently have a higher suicide rate than other prisoners. ${ }^{38}$ These are all signs of deep harm to the spirit.

There is a look in the SHU prisoner's eyes that is haunting. A foreboding look from eyes that have themselves stared into the eyes of madness and human cruelty. Eyes that have looked far into the abyss of emptiness. Eyes belonging to a species of a lesser God. ${ }^{39}$

Prison authorities need the ability to isolate especially dangerous inmates for the protection of staff and other inmates. Some form of solitary confinement may also be justified as a temporary disciplinary measure. The use of extreme forms of solitary confinement as a near-permanent response to a wide spectrum of demonstrated and potential security threats, though, cannot be justified. It is cruel.

To be cruel, punishment need not be mean or angry or violent. It does not have to inflict bodily injury or involve unlawful conduct. It does not require an intent to harm. Cruelty in punishment is the infliction of great suffering on prisoners by staff or institutions who have shown themselves indifferent to that suffering. It involves 
actions or inactions that cause great harm, not as an inevitable consequence of loss of liberty, but because of a failure to see the inmate for who he is and a failure to care about his most basic welfare.

I keep coming back to a story told me by a lay Catholic chaplain, Javier Stauring, some years ago. He related that he had recently visited a man incarcerated in the supermax SHU at Pelican Bay, who he had first met as a teenager in juvenile hall in Los Angeles County. Javier had made the long trip from Los Angeles to Pelican Bay, and on greeting the man, had given him an embrace. The man later said that it was the first time in 14 years that he had been touched by anyone who wasn't medical staff or a guard putting handcuffs on him. Fourteen years. ${ }^{40}$

The modern supermax facility may be seen as the latest in a long line of American penal innovations. From the perspective of prison administrators and corrections officers, it is an extraordinary technical and administrative machine for the safe and lawful handling of some of the most dangerous human beings imaginable.

It is also cruel.

The supermax is state of the art, 21st-century cruelty: clean, cold, reasoned, implacable, indefinite and soul-destructive. In most jurisdictions, in most forms, it is entirely lawful. It defeats threats to life, limb and order by a method of confinement that can profoundly disturb the mind. By preventing ordinary contact with others with whom he might share his daily experience, solitary takes from the prisoner something essential for life as opposed to mere existence. In isolation the soul starves. And no, daily contact with correctional officers who deliver and pick up meal trays is not sufficient to meet the inmate's basic need for social interaction. Nor is shouting down the halls or through vents to other prisoners sufficient to meet the basic human need for community.

Of course if those sent to the supermax really are the worst of the worst, then we may not care how much they suffer. We will only care if we believe there is a human being housed in that isolated cell.

My name is Toby Chavez. New Mexico Penitentiary. Living life in solitary confinement has been the most horrendous experience I've had to endure in all my 43 years on this earth. I have been in prison for 15 years, 13 of them in solitary confinement. ... Each and every day that comes and goes takes a piece of humanity away from me to the point, I don't really know who I am. ... I'm forced to eat every meal, exercise, and play games by myself. I laugh at myself sometimes because it's the only voice I can hear. My own shadow has literally become my only friend. ... I live each day contemplating death, throwing in the towel and just calling it quits. A person can only take so much loneliness. ${ }^{41}$ 


\section{Sexual Violence Inside}

If you were to ask the average American man, or perhaps even boy, what he fears most about going to prison, assuming he had no personal experience of the place, I suspect he would not speak of the long hours that stretch empty of meaning and grind down the mind, body and soul, or of the lack of privacy and crowding inside, or the brute ugliness of surroundings built to resist any expression of individuality or beauty, the awful processed food, or the noise or the company, the endless suspicion and jealousy and maneuvering of those incarcerated, or the sometimes calculated and more often casual disrespect of correctional officers (at least some of them), the capriciousness of prison rules and their administration, the loss of personal identity, the strain on or even destruction of relations with family and friends, the loss of work and the sense of purpose it brings, the loss of reputation, or self-respect, the depression and despair, or the dangers of psychological institutionalization, though all these are common features or consequences of imprisonment. I suspect the average man, or perhaps even boy, would express a fear of being raped. Sexual violence would top the list, a fear greater even than fear of being beaten or killed. The risk of sexual attack occupies the darkest place in the imagination of the American male considering prison life. This may be seen in all the jokes men tell about rape in prison. Jokes often reflect our fears.

Despite this fear, or perhaps even because of it, the public response to prison rape and sexual abuse has featured large amounts of denial, minimization and avoidance. Putting aside the ugliest of responses - that prisoners deserve it - public concerns about the wrong of sexual violence inside remain strongly infused with a sense of inevitability. It's bad of course, quite unfortunate really, but seriously-what are we supposed to do about it? Look at who's in prison.

When inmates are seen just as Offenders, then sexual violence is normal, making major efforts against inmate on inmate attacks seem a poor use of public resources. ${ }^{42}$ Seeing inmates just as Offenders also impedes recognition of sexual wrongs committed by staff. If the inmates are the bad guys (being Offenders), then the prison staff who courageously supervise their confinement must be the good guys. Taking this perspective, we are not likely to recognize or appreciate the wrong of sexual violence and abuse by staff, no matter how prevalent.

And yet, the situation with respect to prison rape in America is changing. In the last 15 years public attitudes towards the wrong have shifted, important legislation has been passed, new evidence about sexual violence and abuse in jails and prisons has been gathered and analyzed; correctional officer training and practices have begun to change. The extent of change can easily be exaggerated, but still the 
direction and significance of the move against sexual violence in prison needs to be appreciated. When it comes to punishment, news of any real improvement should be celebrated because the greatest enemy of reform is despair, the idea that there's nothing we can do, which almost always reflects the view that there's nothing we really want to do.

\section{The Wrong of Sexual Violence, Again}

In our name, judges send offenders to prison for criminal wrongs. The offender's loss of liberty makes personal and concrete society's condemnation of conduct showing disregard for others. This is how we justify incarceration. If incarceration brings sexual violence and abuse, however, its claim to justice is severely undermined.

We know that sexual violence is among the worst of wrongs because of the damage it does to an essential part of the person. Sexuality provides a direct route to the spirit and commandeering that route by forcing sex on another is nothing less than invading the soul. It does enormous damage to the relational person, corrupting the trust capacities needed for close friendship, for romantic love, for family and even for professional relations.

Sexual violence inside jail and prison is awful and wrong in all the ways that it is on the outside, but it is worse inside in some critical respects. Victims often cannot escape their perpetrators, whether they are fellow inmates or staff. They may have to see them daily. Victims often have no support system, no one they can tell. Shame and humiliation make victims reluctant to speak, as on the outside, but in prison there is a more powerful disincentive as well. Telling may be dangerous. Revealing that one has been victimized by another inmate may create a label of victim that encourages further victimization. Revealing staff violence or abuse can lead to retaliation by prison staff.

Sexual violence undermines prisoner reformation. The hurt to victims makes them less capable of the kind of social relations needed for economic and personal success on release. For perpetrators, committing sexual violence while incarcerated reinforces a pattern of masculine dominance and violent identity that is likely to produce more violence in the free world.

Sexual violence and abuse is a sign of a badly run facility and contributes directly to institutional insecurity. To the extent that inmate on inmate sexual violence is prevalent, vulnerable inmates must seek the "protection" of gangs and more powerful inmates, supporting a power structure independent of correctional authorities. Sexual contact between staff and inmates directly undermines the authority of facility rules and staff. 


\section{Patterns of Victimization}

Recent confidential inmate surveys along with other social science research into sexual violence and abuse in prison have provided new and more reliable information about patterns of victimization. In a place characterized by severe imbalances of power, sexual wrongs are committed by the powerful against the perceived weak.

When a person comes to prison, if they see fear in their face, or anywhere, they will be easy prey. ${ }^{43}$

At greatest risk for sexual violence in prison are those with a nonheterosexual orientation: lesbian, gay, bisexual or transgender. In all prison settings, for both male and female prisoners, LGBT status greatly increases the risk of sexual victimization by both fellow inmates and prison staff. ${ }^{44}$ For example, in a survey of recently released state prisoners, an estimated 3.5 percent of heterosexual male inmates were sexually victimized by another inmate; 5.2 percent by staff. The numbers for bisexual males were 34 percent and 18 percent respectively; for homosexual males, 39 percent and 12 percent. $^{45}$

Replicating a pattern found outside of prison, those who have previously been the victims of sexual assault are more likely to be assaulted again in prison. Among inmates with a prior history of sexual victimization, 12 percent of prisoners reported victimization by a fellow inmate during the past year in prison; 6.7 percent reported victimization by staff. ${ }^{46}$

For me, being sexually abused as a child made me an easy target. It was in our file, and the guards could see that. We are easy targets because we learn from a young age to keep our mouths shut. There are repercussions to telling. It is brainwashed into us. It was almost the norm because of how I grew up. I just felt like, "Well, here comes another one."47

For a significant number of male victims of inmate assaults in prison, one assault leads to another. The victim is "turned out" meaning he becomes the target of many.

When I went to prison, I was 28 years old, I weighed 123 pounds, and I was scared to death ... [Later] I had to list all the inmates who sexually assaulted me, and I came up with 27 names. Sometimes just one inmate assaulted me, and sometimes they attacked me in groups. It went on almost every day for the nine months I spent in that facility. ${ }^{48}$ 
Finally, the mentally ill are at greater risk of sexual victimization than are other prisoners. ${ }^{49}$

Most sexual violence and abuse of inmates is not reported to prison officials. The most recent national confidential inmate survey indicates that only a third of inmates who suffered sexual violence or abuse by fellow inmates reported it to staff; less than 6 percent of those who were sexually abused by staff reported it. ${ }^{50}$

A lot of guys don't say enything about what happens to them, because they got to live there. What if they told, what could happen to them ... I know you think they should tell what happens to them. But until you put yourself in there shoes you don't know what you do. Some prisons are hard. Fights, killings, ect. everyday. One thing guys don't like his guys who tell on others. What are your chances if you told someone ${ }^{51}$

Shame is also a powerful disincentive for men who have been raped by other men.

I believe only a minute amount of these incidences get reported; the individules this happens to live in fear. In fear of the perpetrators, but even more signifigant, thay fear other people knowing thay've been victimized in this mannor. They suffer in silence, think thay are less men and fearing the world and thair familys will know of thair shame. ${ }^{52}$

Fear of retaliation for reporting is a significant reason for nonreporting, especially of staff violence and abuse.

I was raped by a corrections official, and I was afraid that if I told anyone what happened, not only would I not be believed, but what would his fellow employees do to me? The warden made it very clear that if anything ever came down to the word of a prisoner versus an employee, she would always believe the employee. If I did report their rapes, would I lose my date to go home? In my case the rapes continued for six months, several times a week. How could I tell my husband of 18 years what happened to me? Would he leave me ${ }^{53}$

One of the most challenging aspects of sexual wrongs in prison involves conduct that falls short of outright force or threats but in which the prisoner is pressured to grant sexual favors. In prison a great deal of sexual activity that may look consensual, actually depends on implicit or explicit threats for noncompliance. The inmate agrees to sex with another inmate, or staff, not because he or she 
wants to, but because he or she believes that the consequences of refusal would be worse.

\section{Changing the Rules, Changing the Culture}

There are few places as rule bound as prisons. A prisoner's life is highly regimented from the beginning of the day to its end. Correctional officers enforce dos and don'ts with respect to the most mundane conduct. Prison is also a place where the unwritten rules can be more important than - and very different from-the written ones. To combat sexual violence and abuse in prison, the written and unwritten rules of prison life need to be reconciled. For real progress, these two different kinds of rules cannot, as they often do today, contradict each other on the question of what kind of force and coercion is permitted inside. This requires a change in prison culture for both correctional officers and inmates.

Both correctional officers and inmates have historically adopted a culture of power masculinity in which manhood is shown by heterosexual conduct and the use of force. Some commentators have called this hypermasculinity. Within this culture, homosexual attraction or any consensual sexual activity with another man represents femininity and a loss of manhood. This explains the "fuck or fight" response of some guards toward inmates who complain of sexual threats or coercion. Either the inmate should submit (proving of course that he is not a real man) or he should fight to defend his manhood (regardless of his chances of winning the fight). Within this scheme, correctional officers may, with evident reluctance, intervene to the extent of ordering the complaining inmate into protective custody (often involving a form of solitary confinement) or transfer him to another institution where a similar scenario may play out anew. Underlying this perspective is a view of inmates as Offenders with little value. Here inmates tell of their encounters with this culture:

The mentality of a lot of guards is that it's only a convicted felon screwing another, so who cares? ${ }^{54}$

I was young and yes i was weak. My weight was only 120 pounds, the first few months i was raped and beat up many times, i would always Fight back, i wanted my attackers to know I was not a Willing Subject for their evilness. I went to the guards for help and was told there was nothing that could be done, that $\mathrm{i}$ would have to stand up like a Man and Take Care of my own troubles. ${ }^{55}$

The guards just turn their backs. Their mentality is the tougher, colder and more cruel and inhuman that place is, the less chance a person will return. This 
is not true. The more negative experiences a person goes through, the more he turns into a violent, cruel, mean, heartless individual, I know this to be a fact. ${ }^{56}$

When a man gets raped nobody gives a damn. Even the officers laugh about it. I bet he's going to be walking with a limp ha. I've heard them. ${ }^{57}$

Many correctional guards today (a number of whom are female) and most prison administrators reject this attitude towards sexual violence by and against inmates. In fact the quotations given here all date from inmate letters written in the 1990s. We will see that important changes in correctional policy on sexual violence have been instituted in many prison systems in the last decade. But it would be naive to think that power masculinity has disappeared as an important influence on correctional staff.

Inmates abide by their own version of power masculinity in which the ability to force sex on other men proves the victim's femininity and simultaneously establishes the perpetrator's masculinity. The rapist of a man is a true man, because he has dominated and taken ownership of the other, making him his "bitch," his "punk." Anyone with homosexual tendencies or a non-heterosexual orientation will be targeted for this kind of violent feminization, explaining their high rate of victimization in almost all institutions.

Inmate victims of sexual violence and abuse frequently blame themselves in some measure for their own victimization. They explain that they did not properly negotiate the norms of prison life and as a result found themselves in a vulnerable position. Or, they should have been able to physically defend themselves. A real man would not have let this happen. This kind of self-blaming occurs even in situations where the victim was truly powerless to prevent victimization.

I remember after he left, the sun was rising, I was standing there in total shock. My body and my mind was numb. ... The fear went on a rampage in my mind, shutting down my whole system. For the rest of the day I was like this. I do remember wanting to kill them or either myself. ... I cannot fully state to you now the actual feelings of guilt or shame I felt at the time. In retrospect, I feel now that there was more I could have done and my mindset that was one of tremendous speculation. But, it all comes down to feelings of being inadequate in the defense of myself. ${ }^{58}$

The bottom line is that real reform requires a change in culture for guards and inmates, perpetrators and victims. The question becomes: how do you accomplish that? Culture seems too diffuse and deep-rooted for any kind of near-term change, which may discourage us from the effort. But when we consider how much cultural change has occurred in the United States in recent years, we have 
reason for optimism. In my lifetime, racial bigotry has gone from being an acceptable prejudice in America to largely unacceptable, attitudes towards women's rights and gay rights have fundamentally shifted; in recent years the prospect of gay marriage has gone from a bizarre idea to a reality. In criminal justice, basic changes have occurred in the culture of policing (this has been particularly important in my home city of Los Angeles) and attitudes towards crimes as diverse as drunk driving, child abuse and sexual assault (treating them more severely) and drug possession (trending towards less severe treatment). Cultures can change, and more quickly than we might expect.

The passage and implementation of the Prison Rape Elimination Act of 2003 (PREA) was both a sign of and a spur to major cultural change with respect to sexual violence and abuse in jails and prisons. This federal law, passed with overwhelming bipartisan support (it was approved by Congress without a single negative vote) created new mandates for services for inmate victims of sexual violence, new institution reporting requirements and funding for confidential inmate surveys to determine the prevalence of sexual violence in state and federal facilities across the nation. For the first time, institutions are publicly ranked according to their dangerousness to inmates. New standards for preventing sexual violence and abuse are now being implemented nationwide. These are positive changes. How much they have changed the reality of prison life for vulnerable inmates remains unclear, however. ${ }^{59}$

I need to offer a caution about the road ahead. Prisons have a number of features that make them natural sites for sexual violence: great disparities in power between guards and inmates, single sex populations, high stress and a community largely cut off from the outside world. In addition, as we saw in the priest pedophile scandal discussed in Chapter 4, the lack of a sexual good-here the inability to express sexuality in a mutually respectful and loving relationship — can lead to sex without consent. If sex is not making love, then it is fucking, a word that connotes a power relation as much as a sexual one. For an inmate who feels largely powerless in prison, fucking (by force) another inmate provides an experience of power. For a $\mathrm{CO}$ or staff member who coerces sex from the vulnerable, the sexual act becomes a visceral exercise of personal power. There will be no simple fixes here.

\section{Conclusion}

New breed guards seldom beat men with clubs. Modern penology is not that personal. The system does a number on the brain cavity that creates psychological cripples. 
We are profoundly social creatures; our lives consist of finding our place in the community of human beings ...

Bessel van der Kolk ${ }^{61}$

Physically speaking, modern times are great times. At least for those who live in the developed world, life spans are longer and daily life is vastly more comfortable than it was a hundred and certainly more than it was two hundred years ago. Air conditioning, central heating, hot and cold running water, antibiotics, anesthetics and antisepsis, the availability of powerful pain relievers-these are just a few of the advances that help most live longer and more comfortably than in ages past.

Mentally, though, the suspicion grows that modern times may be tougher times. The world is more crowded, more competitive, and much, much faster paced than before. Technology and rapidly changing social structures have weakened relational ties in families and communities. The body may be better fed and cared for, but the soul often seems starved for strong connections with others. Even as new organizational systems and technology have created the ability to communicate with extraordinary numbers of persons simultaneously, many feel more isolated. Rates of depression and serious mental illness are high. Suicide is the leading cause of death among a number of groups, young and old.

The same dynamic - better physical health and worse mental health-can be found in jails and prisons. The physical brutalities common in penal institutions just a generation past seem to be on the decline today due to changes in law, corrections culture, and penal technology. ${ }^{62}$ Improvements in physical safety may be paired with worsened mental conditions, though. Without question there are more seriously mentally ill in prison today. ${ }^{63}$ And we know that increased prisoner isolation, longer sentences, overcrowded conditions and far fewer prison programs and services can have a serious effect on the mentally vulnerable. Even as bodies are safeguarded, souls are starved.

In American jails and prisons today we see a trend also found in the free world, of systems and technologies deployed to achieve institutional aims without concern for their soul effects. Institutions package prisoners, like processed food, to keep them physically intact for long periods of time. Human beings though are social creatures; we are relational in nature. I think about that when I visit the High Observation Housing $(\mathrm{HOH})$ units in Tower One of the Twin Towers jail in Los Angeles. This is where the most severely mentally ill male inmates, or at least those most likely to hurt themselves or others, are housed. ${ }^{64}$

Coming onto a high observation floor is like stepping into an enormous, walk-in refrigerator. The walls are white, the fluorescent light is harsh white, and the air is heavily chilled. Inmates are housed in two levels of single cells in pods that face a 
central control booth. Each cell has a heavy metal door with a thick plastic rectangular window in front. Often inmates will stand at their cell door yelling, pounding, screaming.

It is an implacable, hard place that offers little or nothing apart from the necessities of confinement. Inmates spend 22 hours or more in their cells. Meals are delivered through the door slot. There are few, if any programs. No television or radio in the cell. There is a security rationale for the severity of treatment-these are individuals who often present a clear danger to themselves or others-but it is a deeply disturbing place. And puzzling. Confining some of the most mentally ill people in a place that would test the sanity of any human being? Putting the most lost and isolated people in a place further removed from ordinary human connection than almost any imaginable?

It's an example of technology solving a problem at the cost of basic humanity. In meeting institutional needs, we (this is all done in our name, with our money) deny basic human needs for connection and community. There is no intent to harm inmates here. But if those confined are human (and they are), if they have souls (and they do), then real, relational, harm is done by extended confinement under these conditions.

Whether conditions of confinement in jail or prison can be justified depends on moral regard. We should always ask: Are inmates treated as human beings?

\section{Notes}

1 Quoted in Bill Chappell, A Prison Guard Tells His Side of the Story, Over Whiskey, NPR, the two-way, March 10, 2011.

2 Address by The Chief Justice, Record of the Association of the Bar of the City of New York 14, 17 (March 1970 supplement) quoted in Farmer v Brennan, 511 U.S. 825, 854 (Blackmun, J., concurring).

3 Jailhouse Blues: Creators and Producers, "Orange Is the New Black" discuss the pros and cons of playing cons, The New York Times, June 1, 2014.

4 The Sentencing Project, Facts about Prisons and People in Prison, www.sentencingp roject.org (figures based on 2014 Bureau of Justice Statistics reports; hereinafter, Facts about Prisons).

5 National Research Council, J. Travis, B. Western \& S. Redburn eds., The Growth of Incarceration in the United States: Exploring Causes and Consequences (Washington, D.C.: National Academies Press, 2014), p. 211.

6 Facts about Prisons.

7 Facts about Prisons.

8 Amanda Bailey and Joseph M. Hayes, Who's in Prison? The Changing Demographics of Incarceration, Public Policy Institute of California, 8 California Counts: Population Trends and Profiles, August 2006, p. 4. These incarceration rate numbers are 
significantly higher than the incarceration rates cited in previous chapters, because these numbers are only for men-and men comprise the great majority of prisoners.

9 Florida Department of Corrections, 2010-2011 Annual Report, p. 17.

10 Id., p. 8.

11 Doris J. James, Bureau of Justice Statistics, Profile of Jail Inmates, 2002, revised 10/12/ 04, p. 10.

12 Bailey \& Hayes (2006), pp. 7-8.

13 National Research Council (2014), p. 204.

14 National Research Council (2014), p. 205; A. Beck, R. Caspar \& C. Krebs, Bureau of Justice Statistics, Sexual Victimization in Prisons and Jails Reported by Inmates, 201112 (2013), p. 25. Nearly 15 percent of state and federal prisoners had symptoms of serious psychological distress. That compares to a 3 percent rate in the general population. Beck et al. (2013), p. 26.

15 National Research Council (2014), p. 206.

16 Overall, 80 percent of US defendants receive appointed counsel. In the most serious cases, such as homicide, the percentage is somewhat lower as defendants and their families may make enormous efforts, including borrowing against relatives' property to raise money for a private attorney. Caroline Wolf Harlow, Defense Counsel in Criminal Cases, Bureau of Justice Statistics, Nov. 2000, p. 7.

17 See generally, National Research Council (2014).

18 The change in language was made to symbolize a change in policy with respect to incarceration in California. The change became effective in 2017.

19 This was not true for many southern states that followed a more explicitly punitive model. See Edward L. Ayers, Vengeance \& Justice: Crime and Punishment in the $19^{\text {th }}$ Century American South (New York: Oxford University Press, 1984).

20 As an indication of the priority given to rehabilitative programs for prisoners, consider California. In the 2016-17 budget for the California Department of Corrections and Rehabilitation, the state agency responsible for prisons prison and prisoner parole, out of a projected total expenditure of $\$ 10.6$ billion, $\$ 434$ million was allocated for rehabilitation efforts. CDCR Budget, found at www.cdcr.ca.gov/ Budget/.

21 For example, in 2014 fierce political opposition forced New York Gov. Andrew Cuomo to withdraw a proposal he had made to use state funds to expand college education programs for state prisoners. Thomas Kaplan, Cuomo Drops Plan to Use State Money to Pay for College Classes for Inmates, The New York Times, April 3, 2014.

22 For indications of nondeadly violence levels in prison, see National Research Council (2014), p. 224.

23 The latest numbers for state and federal prisoners was an annual rate of victimization of 2 percent for incidents involving another victim and 2.4 percent for incidents with staff. Beck et al. (2013), p. 6. This ratio is consistent with prior surveys. Under the survey's methodology, inmate on inmate victimization is limited to nonconsent sex. The staff incidents include both so-called willing and unwilling sex according to the inmate reporter's distinction. Most but by no means all staff incidents are labeled as willing, but may nevertheless involve significant implicit or explicit use of coercion. All 
sexual contact between staff and inmates is illegal and the power imbalance involved makes any concept of real consent difficult at best. The most troubling figures involving staff abuse come out of juvenile facilities where inmates are most vulnerable to coercion and the sexual contact may be criminal, regardless of consent. In the most recent survey of such facilities, 2.5 percent reported victimization by another inmate; 7.5 percent by staff. Allen J. Beck, Bureau of Justice Statistics, Sexual Victimization in Juvenile Facilities Reported by Youth, 2012, p. 4. In all facilities, most of the sexual contact by staff involves female staff with male inmates. Id., p. 5.

24 For an argument that correctional officers are more accurately termed prison guards because of their nearly exclusive focus on security, see Michael Santos, They're Prison Guards, Not Correctional Officers, in Prison News Blog, Prison News and Commentary, Feb. 9, 2009, found at prisonnewsblog.com.

25 The Martinson article that received most notice was, What Works? - Questions and Answers about Prison Reform, The Public Interest (Spring 1974), pp. 22-54. It was based on Douglas Lipton, Robert Martinson \& Judith Woks, Effectiveness of Correctional Treatment: A Survey of Treatment and Evaluation Studies (Santa Barbara, CA: Praeger, 1974).

26 See Samuel H. Pillsbury, Note, Creatures, Persons and Prisoners: Evaluating Prison Conditions under the Eighth Amendment, 55 So. Cal. L. Rev. 1099 (1982).

27 Charles Dickens, American Notes for General Circulation (New York: Penguin, 2001), pp. 146-7.

28 For modern accounts of the penitentiary movement in the United States, see Adam Jay Hirsch, The Rise of the Penitentiary: Prisons and Punishment in Early America (New Haven: Yale University Press, 1992); David Rothman, The Discovery of the Asylum: Social Order and Disorder in the New Republic (Piscataway: Aldine Transaction, 2002). For contemporary accounts, see Gustave de Beaumont \& Alexis De Tocqueville, On the Penitentiary System in the United States and its Application in France, H. Lantz ed., F. Lieber trans. (Carbondale: Southern Illinois University Press, 1964, 1833); William Crawford, Report on the Penitentiaries of the United States (Montclair, NJ: Patterson Smith, 1969, 1842). The New York system was also called the silent system because it enforced total silence between inmates. Prisoners would work together in the day, in silence. The Pennsylvania system was also called the separate system because in its original design (and as viewed by Dickens), prisoners were individually housed in a single cell, day and night.

29 One of the best depictions of modern solitary confinement and its effects on inmates is in the television series Rectify (2013-16), created by Roy McKinnon and originally aired on SundanceTV. The main character Daniel Holden spent 19 years on death row before his release based on new DNA analysis. Flashbacks show conditions on death row; present day sequences show the long-term effects of the confinement on Holden.

30 On Attica, see Tom Wicker, A Time to Die: The Attica Prison Revolt (New York: Quadrangle/New York Times, 1975); Heather Ann Thompson, Blood in the Water: The Attica Prison Uprising of 1971 and Its Legacy (New York: Pantheon, 2016). On New Mexico, see Roger Morris, The Devil's Butcher Shop: The New Mexico Prison Uprising (Albuquerque, N.M.: University of New Mexico Press, 1988).

31 See Doris J. James and Lauren E. Glaze, Bureau of Justice Statistics Special Report, Mental Health Problems of Prison and Jail Inmates, September 2006, p. 10. The report 
indicated that $58 \%$ of state prisoners with a mental health problem were charged with breaking facility rules compared with $43 \%$ of those without a mental health problem. A similar disparity was documented in jails.

32 Statement of Professor Craig Haney at Hearing of California Assembly Public Safety Committee, Aug. 23, 2011, quoted in Sal Rodriguez, "Pawns in a Failed Experiment": Testimony of Dr. Craig Haney on Solitary Confinement, Sept. 1, 2011, found at http s://solitarywatch.org/2011/09/01/pawns-in-a-failed-experiment-testimony-of-dr-cra ig-haney-on-solitary-confinement/

33 Stuart Grassian, Psychopathology of Solitary Confinement, 140 Am. J. Psychiatry 1450-54, 1452 (1983).

34 Grassian (1983), p. 1452.

35 Grassian (1983), p. 1453.

36 Grassian (1983), p. 1453.

37 Kenneth L. Appelbaum, et al., A National Survey of Self-Injurious Behavior in American Prisons, 62 Psychiatric Services 285, 287 (2011). The authors note that such behavior may represent a maladaptive effort to communicate or achieve a particular end, but still represents a symptom of mental illness that requires treatment. Id. at 289.

38 See Jeffrey L. Metzner \& Jamie Fellner, Solitary Confinement and Mental Illness in U. S. Prisons: A Challenge for Medical Ethics, 38 J. Am. Acad. Psychiatry \& Law 104 (2010) (notes 9-10).

39 From If the SHU Fits: Voices from Solitary Confinement, compiled by Andy Griggs \& Melvin Ishmael Johnson (2013), p. 5, found at www.ncrcat.org/if-the-shu-fits.

40 The fact that Javier was able to embrace the man was itself unusual. Visits to prisoners in the SHU normally occurred behind barriers; little or no physical contact was allowed. For many years, California held large numbers of inmates indefinitely in its specially built supermax unit, the Security Housing Unit at Pelican Bay, primarily based on prison gang identification. Prison officials employed an internal process called validation that depended on confidential informants and circumstantial evidence to identify gang membership. Once validated as prison gang members, inmates could secure release from solitary only by "debriefing," meaning revealing their knowledge, with names, of anyone else involved in a prison gang, actions that could subject inmates and even their families to gang retaliation. For conditions in the Security Housing Unit, see Madrid v. Gomez, 889 F. Supp. 1146, 1227-37 (N.D. Cal. 1995). For an overview of the history of the SHU at Pelican Bay and eventual inmate resistance in the form of a hunger strike, see Alessandro Camon, The Short Corridor: How the Most Isolated Prisoners in America Took on the System, and Won, Los Angeles Review of Books, May 15, 2016, found at https://lareviewofbooks.org/article/shortcorridor-isolated-prisoners-america-took-system-won/.The 2015 settlement of Ashker v. Brown, an inmate lawsuit brought against the state, changed state use of solitary confinement. At the time, more than 500 inmates had been held in the Pelican Bay SHU for more than 10 years; 78 for more than 20 years. Summary of Ashker v. Governor of California Settlement Terms, found at https://ccrjustice.org/sites/default/files/a ttach/2015/08/2015-09-01-Ashker-settlement-summary.pdf. Under new prison policy, confinement to solitary confinement is limited to those who have committed serious rule violations, and then for a determinate term. Another form of less restrictive 
but separate confinement was created for inmates who posed general security concerns. Id.; see also Jessica Berg, CDCR converts Pelican Bay SP Security Housing Unit to a general population for low-level offenders, Inside CDCR, August 9, 2017, found at https://www.insidecdcr.ca.gov/2017/08/cdcr-converts-pelican-bay-sp-secur ity-housing-unit-to-a-general-population-for-low-level-offenders/.

41 Griggs \& Johnson (2013), p. 8.

42 Evidence of this perspective on inmates and their sexual victimization can be found in Justice Clarence Thomas's concurring opinion in the United States Supreme Court case of Farmer v. Brennan, 511 U.S. 825 (1994). The petitioner was Dee Farmer, a federal prisoner who is transgender: a biological male with a feminine appearance. Farmer said that after being transferred from one federal prison to another, authorities placed him in the general prison population, putting him at great risk. Three days later he was severely beaten and raped. Farmer claimed that his treatment was unconstitutional, amounting to cruel and unusual punishment. Thomas wrote in his opinion: "Prisons are necessarily dangerous places; they house society's most antisocial and violent people in close proximity with one another. Regrettably, "[s] ome level of brutality and sexual aggression among [prisoners] is inevitable no matter what the guards do ... Unless all prisoners are locked in their cells 24 hours a day and sedated." Id. at 858-9, quoting McGill v. Duckworth, 944 F.2d 344, 348 (7th Cir. 1991). Prisoners here are seen as antisocial and violent individuals. But even if criminal conviction is synonymous with antisocial character, the violent label is overbroad. Many prisoners serve time for nonviolent offenses. Farmer, for example, was in prison for credit card fraud. Later, in laying out his personal view (not shared by the Court) that the Eighth Amendment's cruel and unusual clause applies only to the sentence ordered and not the conditions of confinement, Justice Thomas wrote: "Because the unfortunate attack that befell petitioner was not part of the sentence, it did not constitute 'punishment' under the Eighth Amendment." Id. at 858. Thomas's view of prison inmates emerges most clearly in the words used to characterize inmate rape: "regrettable" and "unfortunate." These are two of the weakest critical terms in the English language, yet they refer to the worst form of personal violence short of homicide.

43 M.O., Illinois, 10/20/96 in Appendix I, Letters from Prisoners, in Human Rights Watch, No Escape: Male Rape in U.S. Prisons (2001), p. 186, https://www.hrw.org/ reports/2001/prison/report.html.

44 Beck et al. (2013), pp. 18, 30. See also Dee Farmer's case, discussed previously in notes.

45 Allen J. Beck \& Candace Johnson, Bureau of Justice Statistics, Sexual Victimization Reported by Former State Prisoners, 2008, May 2012, p. 16.

46 Beck et al (2013), p. 19.

47 Robin, an incest survivor, quoted in Just Detention International, Hope Behind Bars: An Advocate's Guide to Helping Survivors of Sexual Abuse in Detention (2015), p. 4 (hereinafter Hope Behind Bars), found at https://justdetention.org/wp-content/uploa ds/2015/10/Advocates_Manual_FINAL.pdf.

48 Account of Bryson Martel, quoted in David Kaiser \& Lavisa Stannow, The Rape of American Prisoners, The New York Review of Books, March 11, 2010, p. 57.

49 Beck et al. (2013), p. 25; V. Jenness, C. Maxson, K. Matsuda \& J. Sumner, Violence in California Correctional Facilities: An Empirical Examination of Sexual Assault, 
The Bulletin, Center for Evidence-Based Corrections, June 2007, pp. 2-3, found at http://ucicorrections.seweb.uci.edu/files/2013/06/BulletinVol2Issue2.pdf.

50 Hope Behind Bars. p. 10; see also Beck \& Johnson (2012), pp. 30-2.

51 M.F., Ohio, 9/6/96 in Human Rights Watch (2001), p. 167.

52 B.H., Florida, 10/22/96 in Human Rights Watch (2001), p. 188.

53 Jan Lastocy, quoted in Hope Behind Bars (2015), p. 12.

54 R.L., New York, 9/9/96 in Human Rights Watch (2001), p. 169.

55 B.L., Florida, 9/5/96, Human Rights Watch (2001), p. 166.

56 R.L., New York, 10/21/96, Human Rights Watch (2001), p. 187.

57 J.G., Minnesota, 9/7/96, Human Rights Watch (2001), p. 168.

58 R.D., Virginia, 9/16/96, Human Rights Watch (2001), p. 174.

59 The latest national survey indicates a decline in "willing" sexual activity with staff but that the rate of other forms of sexual victimization remains the same as before. Beck et al. (2013), p. 6. Current evidence is conflicting, ambiguous or complex on a number of important aspects of sexual violence and abuse in jails and prisons today. Prisoner accounts of prison rape almost universally describe youth as a significant risk factor; recent confidential inmate surveys do not support this, however. Inmates over the age of 55 are at somewhat lesser risk than younger inmates, but prisoners in their teens and early 20s do not report a higher level of victimization than other inmates. NIS 2012, pp. 18, 21. It may be that lack of prior experience with incarceration is a more important factor than youth alone. Confidential surveys indicate that more female inmates suffer sexual violence and coercion from fellow inmates than male inmates do. Beck \& Johnson (2012), pp. 15-16. Questions remain about the significance of this finding. Does it stem from different levels of reporting by gender? Are there differences of significance in the kind of coercion experienced? Race is also a risk factor in victimization, but with potentially important variations between prison systems and distinctions between abuse by inmates or by staff. Nationally white inmates are at greatest risk for inmate on inmate violence. See Beck et al. (2013), p. 17 (whites and mixed race inmates at greater risk than black inmates). In California, Hispanics make up the majority of the prison population. The most recent national survey of juvenile correctional facilities also shows higher victimization rates in youth on youth sexual violence for whites than blacks or Hispanics. Allen Beck \& Ramona Rantala, Bureau of Justice Statistics, Sexual Victimization Reported by Juvenile Correctional Authorities, 2007-12, January 2016, pp. 7-8.

60 Jerome Washington, Iron House: Stories from the Yard (Fort Bragg, Calif: QED Press, 1994) p. 7.

61 Bessel van der Kolk, The Body Keeps the Score: Brain, Mind, and Body in the Healing of Trauma (New York: Viking, 2014).

62 One of the best indicators is a decline in homicide rates in prison. These have dropped from a rate of 54 per 100,000 in 1960 to 4 per 100,000 in 2002. Bureau of Justice Statistics, Special Report, Suicide and Homicide in State Prisons and Local Jails (Aug. 2005). On sexual violence in prison, see the discussion earlier in the chapter.

63 Estimates are that the percentage of prisoners who are seriously mentally ill nearly tripled from 1983 to 2004-5. E.F. Torrey et al., More Mentally Ill Persons Are in Jails and Prisons Than Hospitals: A Survey of the States, Treatment Advocacy Center, May 2010, 
p. 1. The historical increase in mentally ill prisoners coincides with a steady decrease in state-funded hospitals and other residential facilities for the mentally ill. Id. at p. 8. The numbers of mentally ill prisoners in local jails and state prisons continues to climb today. Abby Sewell, Mentally Ill Inmates Are Swamping the State's Prisons and Jails, Los Angeles Times, June 19, 2016.

64 Almost all the inmates in both Tower One and Tower Two receive some form of mental health care, making this likely the largest mental health facility in the West. 


\section{PART THREE}

Relational Justice 


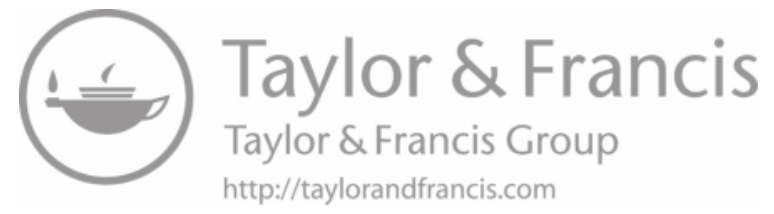




\section{INTRODUCTION TO PART THREE}

Crime, prosecution, punishment. Rights violated, rights vindicated. This is the standard account of American criminal justice. A story that begins with wrongdoing, concludes with the wrongdoer's punishment. As the judge's gavel falls for the last time and the defendant is led away in chains, the credits roll and the music swells. The audience gets up to leave, or at least switch channels. The case is over. Our journey so far has followed a similar progression from offense to conviction to punishment. But this book is about more than crime and punishment. We have set off in search of a larger conception of justice and this requires a longer, and more complicated journey. In Part Three we transition from justice as standardly conceived in America-justice under law-to what I call relational justice.

American criminal justice as we know it today is all about the vindication of individual rights under law. A violation of a person's rights to property, autonomy or life leads to public condemnation in conviction and punishment. Rights violated, rights vindicated. This is what law does. But if justice is to be victim-centered, this is not enough. Justice must also contemplate the relational needs of victims, which means we must consider the possibilities of relational justice.

In relational justice we still punish wrongdoing, but we also address the relational harms and wrongs of violence. If violence harms the soul (which it does), if violence tears and often destroys the connections that make life worthwhile (which it does), then community actions that help heal the soul should be part of doing justice. This justice is about just relations.

In Chapter 7 we examine how justice under law may serve the needs of victims in providing for their future security and opportunities to be heard in the legal 
process. In Chapter 8, we look at relational healing for victims and what this entails for individuals, community and public officials. In Chapter 9 we take up the challenges of relational healing for offenders. In Chapter 10 we consider community healing for the wounds of race violence. In Chapter 11 I suggest how individuals might live out a larger conception of justice. 


\section{7}

\section{VICTIMS AND JUSTICE UNDER LAW}

I suspect that when historians of American criminal justice look back at the last 50 years in the United States, they will call it the Age of the Victim. That is because so many of the movements for change in criminal law and policy have depended on the experience of victims, particularly victims of criminal violence. (Unless otherwise noted, I use the word victims here to include both direct victims and family member survivors.) Calls for change in the law's treatment of sexual violence, child abuse, domestic violence, and drunk driving have all relied heavily on what these crimes do to victims. Support for the death penalty, for longer prison sentences for offenders, for changes in sentencing hearings, and for post-penalty sanctions such as civil commitment of the sexually violent and lifetime registration of sex offenders, have been based on past victim experiences and fears of future victimization. It's all for the victims and it's all about the law.

This chapter looks at what the criminal law can do for those harmed by violence. The arrest, conviction and punishment of wrongdoers may provide some assurance of personal safety and continued moral order in the community. In recent years, improvements in policing and changes in the prosecution and punishment of certain crimes have contributed to lower crime rates and a greater sense of security in many American communities for victims and others. And yet, law enforcement often falls short in its efforts to hold wrongdoers accountable. We will look especially at shortcomings in the investigation of sexual violence here.

We will also look at important changes in criminal justice in the late 20th and early 21 st centuries brought by the victims' rights movement in the United States. Advocates successfully promoted increased punishment for violent crime and the enactment 
of new procedural rights for victims in the courtroom. These changes will be the subject of the second half of this chapter. We will particularly examine the right to make victim impact statements at sentencing hearings. In practice, these statements go well beyond their legal function in addressing judges on sentence. Speakers address relational needs, which means that to incorporate them into the legal process, we will need to develop a conception of relational justice.

\section{Dreams of Law, Realities of Law's Enforcement}

In our entertainment - at the movies and on television-we Americans glory in justice by force. Get that bad guy. Crush him. We saw this in Part One. But in our public discourse about the challenges of crime, we focus on justice by law. Faced with outbreaks of senseless violence, liberals turn to gun control legislation; conservatives answer with the Second Amendment. When Americans saw a need to do more to combat child abuse, the response in most jurisdictions was to pass laws that require a wide variety of persons, from teachers to nurses to clergy, to report any credible suspicions of child abuse to the authorities. Debates about domestic violence for a long time concerned rules for the arrest and prosecution of suspects. Changes in our approach to sexual assault have led to changes in legal rules concerning admissible evidence in rape cases: an elimination of sexual reputation evidence, reform of victim resistance requirements, and greater admission of similar, prior bad acts by defendants. Talk of getting tough on crime to minimize future victimization usually meant support for increased punishment. Across a range of offenses, from drunk driving to murder, a desire to get tough on wrongdoers has led to tougher sentencing laws and policies.

The emphasis throughout is on change by legislation. We hear: there should be a law against that. Or, the law must be changed. When the question is what to do about crime, the answer is mostly more, or different laws.

Soon we will take up laws that have been enacted on behalf of victims as part of America's victims' rights movement. Before we do that though, we need to consider criminal law enforcement. The day-to-day challenges of law enforcement are less discussed than the need for legislative change, but meeting them is usually more important to victims.

\section{Security and Accountability}

Victims of violent crimes generally want from the criminal justice system what every member of the public wants in the wake of wrongful violence: an assurance of future safety by bringing perpetrators to account. We all want to be safe. 
What should count as basic safety is not always easy to say, however. Life is not safe. Spending all resources to safeguard physical existence will diminish the life that we have. For victims, defining security is particularly challenging, because of their trauma-induced sensitivity to any repeat of their particular violence experience. I can face anything but that. This can skew overall safety priorities.

Making safe includes the essentials of modern crime-fighting: a public willing to report crime and cooperate with investigators, police who are well-trained and engaged with the community, investigative and prosecutorial agencies that readily share information and a legal process capable of reliable assessment of guilt and determination of just punishment. This is the ideal. What is the reality?

In crime shows, the police, or whoever else acts as crime investigator, almost always gets the bad guy. That is the final satisfaction of the drama. We all know that this is not real life, but many Americans still discount the gap between fiction and reality. They do not realize that most crimes of violence in the United States do not result in arrest.

In 2015, the nationwide clearance rate for all crimes of violence according to the FBI was 46 percent. ${ }^{1}$ This means that police in 46 percent of violent crime cases developed enough evidence to arrest a suspect. To put this another way, it means that more than half of all reported violent crimes go unsolved. That is a lot of unsolved crimes. And yet, it almost certainly overestimates police success in crime investigation.

Clearance rate numbers come from voluntary annual reports made by police departments to the FBI. Police departments vary greatly in their ability and interest in keeping accurate crime statistics. Departments have strong incentives to keep the numbers of serious reported crimes down, while keeping clearance rates up. In addition, even if we assume a high level of integrity and accuracy in keeping local crime figures, clearance rates only take account of crimes reported to police. Unreported crimes do not figure in clearance statistics, though we know that many serious crimes go unreported, especially domestic violence and sexual violence. Police may also, in a variety of ways, discourage victims from making an official police report, which keeps these offenses out of the tally as well. Finally, these are figures for cases cleared by arrest. They do not say anything about whether the suspect was then convicted or punished. Conviction and punishment is for many Americans the real test of whether justice under law is done.

Clearance by arrest rates varies significantly according to crime. Among serious crimes, police do best with homicide. Nationwide, the clearance rate in 2015 for murder offenses was 61.5 percent. For rape (again remembering this is only for reported rapes), the figure was 37.8 percent. For robbery, perhaps the most common crime of violence, the national clearance rate in 2015 was 29.3 percent. $^{2}$ 
True democracy is impossible where there is widespread impunity under law for wrongful violence. This is a hallmark of nations or regions where government has failed or is failing. Even in the US today, there are neighborhoods where violent wrongdoers mostly get away with their crimes. There are places with high rates of gang violence, and schools and institutions with high rates of sexual assaults. In many families, domestic violence is endemic. In many prisons and jails, violence is common. In all these places, victims of violence need some assurance that they will be safe in the future, because they have not been before. Even with violent crime rates falling overall, improvements in law enforcement are urgently needed in many jurisdictions. Especially with respect to crimes of sexual violence.

\section{Accountability for Rape}

[I]n homicide, there are real victims; all of our cases are bullshit. ${ }^{3}$ complaint of detective in Baltimore's Sex Offense Unit

A striking example of law enforcement failing victims is in the investigation of sexual offenses in many jurisdictions. In-depth studies of selected police departments across the nation by the US Department of Justice have revealed repeated instances of police disinterest, incompetence and prejudice in responding to rape victims. Questions like, "Do you really want to ruin this guy's life?" and judgmental comments about what the victim was wearing, or the time of night or location of the interaction, indicate that many police officers still engage in victim blaming, and still hold to pernicious stereotypes about what is a "real" rape. It is clear that many police officers, both patrol and detective, are at best uncomfortable handling the basic sexual assault case. ${ }^{4}$

Listen to the voices of two victims of sexual violence who said they were mistreated by police in the nation's capital in recent years.

Reporting to the police was far more traumatizing than the rape itself. ${ }^{5}$

By failing to classify the crime committed against me as an attempted rape or sexual assault, by ignoring my account of the story, you condemn me to a life where I mistrust the police, abandon any faith I possessed in the criminal justice system, and you have caused me more victimization than the actual perpetrator of the crime committed against me. Moreover, you failed the community you have sworn to protect. ${ }^{6}$

The underreporting of rape cases by police departments, their misclassification in reporting systems, and the failure to conduct basic, competent investigations—all of 
which were documented by the Department of Justice investigators in a number of jurisdictions-point to systemic problems in many police departments. Whatever the pronouncements of public officials and police chiefs, and whatever their sincerity, the actual commitment of many police officers to the investigation of sexual assault cases is lacking.

A clear example of the lack of commitment to victims of sexual assaults by law enforcement has come in recent controversies over the failure to process rape kits. When someone reports being raped to police, she or he is usually given a thorough and highly intrusive physical examination at a hospital which produces evidence collected in a rape kit. The aim is to preserve any physical evidence, especially DNA evidence, that may assist in the identification and prosecution of the attacker. The assumption of most rape victims is that once collected, the rape kit will immediately go off to a crime lab for processing and, as on TV crime shows, quickly produce investigative leads. At least they expect the evidence will be processed. In practice, in Los Angeles and many other cities until recently, unless a suspect was already identified, many rape kits went into storage without being processed. If a suspect in the case was later identified by other means, then the kit might be processed to provide corroborating evidence for prosecution. When the failure to process most rape kits was revealed, many rape victims felt betrayed. An implicit promise had been broken.

Victim advocate groups raised an outcry over this practice, leading to new funds and policies for processing all rape kits. The new testing, in tandem with developments in DNA analysis and the taking of DNA samples from a wider range of arrestees and prisoners than before, has produced important new evidence of crimes, including offenses by serial rapists. In at least in some instances, it appears that testing the kits might have prevented subsequent sexual attacks. ${ }^{7}$

Regardless of its importance, improving law enforcement investigations in sexual violence cases (or other cases) is a difficult undertaking. Citizen oversight of police departments is often weak and almost always highly localized. Better practices require better training and often more investigators, which takes money that taxpayers often are unwilling to pay. Police forces and law enforcement organizations can be formidable political players, with significant control over access to critical criminal justice information. These features can make it difficult for outsiders to pass judgment and change police practices. Reforms pushed from the outside or from the top down may be subverted by the rank-and-file over time. Even more than most professions, law enforcement officers resist outsiders telling them how to do their job. From a reform perspective, changing the laws that govern courts and law enforcement seems much easier. Judges, prosecutors and law enforcement personnel have to obey the law, right? This helps explain why most criminal justice 
reform activity centers on legislation. This has certainly been true of the victims' rights movement.

\section{The Victims' Rights Movement: Punishment and Voice}

In the late 20th century, a movement arose in the United States to give victims of crime their own legal rights. ${ }^{8}$ This happened at a time when all of America seemed to be engaged in rights agitation. From then until now, almost every campaign for major legal and social change in America has included a call for new or expanded legal rights. (By legal rights, I mean legally enforceable demands that an individual or a group may make against the state.)

Beginning with the civil rights movement of the 1950s and 1960s, individual rights were the focus for many different public interest groups in America. In addition to long-recognized rights to free speech, due process and racial equal protection, there have been calls for women's rights, for rights to choose, rights to privacy, disability rights, gun rights and the right of same sex couples to marry, to name some of the most important. In the criminal area, the United States Supreme Court interpreted the federal Constitution to give criminal defendants in state courts a range of new individual rights, including Miranda rights in custodial interrogation, the right to exclude evidence from illegal searches and seizures under the Fourth Amendment, the right to appointed counsel under the Sixth Amendment, and limitations on the death penalty under the Eighth Amendment. Victim advocates saw a major imbalance here. If persons accused of serious wrongdoing have so many rights, what about those who have been wronged? Victims should have some rights as well.

The flag of victims' rights has been raised on behalf of a wide variety of criminal justice reforms. Early efforts to support victims of violent crime led to changes in rape law and its prosecution. Requiring court orders for victim restitution from defendants was also an early aim. Because defendant resources for restitution are often very limited, both federal and state governments have provided some (limited) financial assistance to victims of violence for medical and therapeutic services.

Campaigners for victims' rights have won a variety of rights to information and participation in criminal cases. These include rights to be notified about the filing of charges, bail decisions, the scheduling of hearings, notification of guilty pleas and rights to speak at sentencing and parole hearings. Statutory rights for victims to attend trial and a separate victim right to a speedy trial have been enacted in many jurisdictions.

Finally, many recent efforts on behalf of victims have sought to make criminal prosecutions easier, and punishment following conviction more severe. 


\section{Victims and Tough on Crime Legislation}

Especially in the 1980s and 1990s, victims' rights and tough on crime politics often appeared synonymous in public discussions. For example in California, an important early ballot box proposition that approved a number of pro-prosecution changes in criminal law and procedure was titled the Victim's Bill of Rights (1982). A more recent proposition which included new restrictions on prisoner rights to parole hearings was titled the Victim's Bill of Rights Act of 2008: Marsy's Law. We saw, in Chapter Five, how Three Strikes legislation was championed by and on behalf of victims of homicide, and how campaigns for life sentences for juveniles were framed in terms of preventing victimization.

Since the 1980s, federal legislation on crime has frequently been brought in the name of crime victims, for example, the Victim and Witness Protection Act (1982); Victims of Crime Act (1984); Victims of Child Abuse Act (1990); Victims' Rights and Restitution Act (1990); Violence Against Women Act (1994); Mandatory Victims' Restitution Act (1996); Victims' Rights Clarification Act (1997); Crime Victims with Disabilities Awareness Act (1998); The Scott Campbell, Stephanie Roper, Wendy Preston, Louama Gillis and Nila Lynn Crime Victims' Rights Act, part of the Justice for All Act (2004); and the Adam Walsh Child Protection and Safety Act (2010).

In previous eras, questions about criminal procedure and sentencing were largely determined by courts and public officials working closely with criminal justice professionals and experts. Now ordinary citizens took leading roles. In the 1980s and 1990s, from pictures of missing children on milk cartons, to crime stories on the nightly news and TV magazine shows, to emotional appearances on talk shows, to political speeches featuring victimization stories and appearances by victim survivors, accounts of awful criminal violence became regular features of modern American public life. This laid the emotional and political foundation for increasing severity in punishment. ${ }^{9}$

Until very recently, the most influential and best funded victims' rights groups have focused their public advocacy on increasing convictions and more severe punishment of offenders. In California, such groups have played important roles in longer sentences for repeat offenders, for juveniles and gang members, and for limits on parole. ${ }^{10}$ We saw this in Chapter 6 , where we looked at the dynamics and consequences of new laws mandating life sentences for juvenile murderers and offenders. There we also looked at the justice of these laws according to principles of moral regard. Now I want to consider how the kinds of cases that brought victims' rights to public attention have shaped the way we talk about criminal justice in America. 


\section{Victim Representation: The Limits of Headline Cases in Setting Criminal Justice Priorities and Policy}

The American public came to know the victims' rights-tough on crime movement largely through headline cases of awful violence, virtually all murders. The most prominent victim advocates have generally been members of a family with a loved one who was killed. Most advocates have been white. Most of the victims were white and young, often children. Most victims were from economically stable families; rarely did they come from the margins of society.

Headline crimes are almost by definition, especially terrible. That's what earns the headlines. The headline crimes of the victims movement were (and are) terrible because they touched on the fear that anyone in society might lose a treasured family member, even a child, to a stranger's predatory attack. The worst of these crimes included a sexual assault.

Almost by definition, headline cases are unusual cases. The headline cases in the victims movement have been unusual in many ways. Consider the kind of violent crime: murder. Even in high crime areas, homicides are relatively unusual. In numerical terms, there are few compared to aggravated assaults, robberies, crimes of sexual violence, and domestic violence.

The headline murder cases of the victims' rights movement have almost always involved stranger killings, but many homicides occur between persons who had a prior relationship to each other. The stranger attacker model is particularly misleading when sexual violence is done to a child. Although strangers who sexually attack children are enormously dangerous, they represent a small percentage of child sex abusers. Most young people who suffer sexual violence are victimized by persons that they and their families knew and trusted. ${ }^{11}$

Most, though by no means all, of the headline cases in the victims' rights movement have been cases in which there was an arrest and prosecution and significant punishment. Many cases, of course, never get as far as an arrest.

Many of the murder cases highlighted by the victims' rights movement have involved a perpetrator of a different race than the victim. Yet most homicides are committed within a racial group, not across race lines. Whites mostly kill whites, blacks mostly kill blacks, Hispanics mostly kill Hispanics. And men mostly kill men. Many of the victims in headline cases have been female, but the majority of homicide victims are male. ${ }^{12}$

And in terms of percentages, most victims of homicide come from the social and economic margins. Disproportionately, they are have-nots. This means that a disproportionate number of persons murdered in the United States are black and brown. ${ }^{13}$ This means that most victims do not look like the mostly white victims in 
headline cases. It also means that most homicides, being crimes against the poor and people of color, go largely unnoticed by the public.

Given the differences between headline cases and ordinary cases of criminal violence in America, the question becomes how much this matters for the discussion of criminal justice policy. All of us understand that stories in the news are not necessarily representative of what happens at other times and places. That does not change their reality, however. Even if statistical outliers, headline crimes have real victims and real consequences. The fact that a crime has a white and middle-class victim does not make it any less deserving of our concern than if the victim is poor and minority. But neither does it make it more deserving of our concern. The same is true of the offender's race. The problem is that our visceral responses to crime often turn on similarities between ourselves and victims, and dissimilarities between ourselves and defendants. Race and class similarities-and differences-can be powerful though often unconscious influences on how we respond.

The stories we choose to tell about criminal justice matter because they help shape how we perceive major problems in criminal justice and their solutions. Victims' rights advocates often root their public presentations in their own personal stories. The accounts they provide describe the person whose life was taken as uniquely wonderful, and their killers as thoroughly evil: see what they did to my loved one. The personal truth of their accounts is powerful and undeniable. But it is not the only truth relevant to punishment policy.

Victim advocates champion moral regard for those whose lives have been taken, insisting upon their specialness, the loss of their life opportunities, and their great value. They do not wish to acknowledge-and frankly it would be ludicrous for us to think they should personally acknowledge-the uniqueness and value of the perpetrator. But if justice requires moral regard for all, then we are missing something important to the larger discussion unless that is supplied. An account that pits a person (the loved one) against a monster (the perpetrator) presumes the need for the wrongdoer's annihilation. Monsters need slaying. If such accounts set the terms of the public discussion, it becomes difficult to imagine a view of crime and punishment in which there might be moral regard for defendants and their families, as well as for victims and community.

The headline cases, and the most prominent victim advocate voices, may also mislead on the question of what most victims want in terms of punishment. In fact many victims of violence do not see severe punishment as their greatest justice need or the highest priority for society in responding to violence.

Some victims are not overly concerned with punishment policy because in their case, no wrongdoer is likely to be punished. No suspect has ever been identified, let alone arrested or prosecuted. For some victims, religious, moral or other values incline them 
to less punitive responses. We see this with some regularity in cases where surviving family members in a murder case disagree among themselves about the death penalty for the defendant. For other victims, their life experience makes them much less trusting of law enforcement and much less sanguine about the justice of the American legal system than many victims' rights advocates are. Being a racial minority in America, living in a highly stressed community, and struggling to make it economically, gives many victims a different perspective on policing and punishment. The good guy, bad guy categories that are so popular in the populist politics of criminal justice can look very different in the neighborhoods where some of the worst violence occurs. In these places there are more than a few families that have direct experience of both sides of criminal justice: the murder of a loved one and the loss of a family member to a long prison sentence. In general, the movement's emphasis on punitive results is not likely to resonate with victims who have had bad experiences with law enforcement, or who have seen or heard about others who have been poorly treated.

Finally, victims who struggle with the traumatic effects of violence-who desperately need emotional and spiritual healing to put the most basic parts of their life together-may find that ramping up the punishment of convicted offenders is not their first, or even second priority. They are focused on their own survival.

The bottom line is that there is no automatic connection between victim interests and harsh punishment. In the end, the merits of a particular punishment regime depend on our shared justice values. In the discussion of what punishment is just, victims have an important voice; more accurately, they have many different and important voices. We must listen to them, even when we would rather not. Perhaps especially, when we would rather not. But in the end, punishment can only be justified by principles of justice that apply equally to all.

\section{A New Voice in the Courtroom}

In contemporary criminal justice the victim serves only as a means to an end, namely a piece of evidence to be used by the state to obtain a conviction. ${ }^{14}$

This statement from a criminologist in 1976 captured what was for many years the American law's view of the victim in the criminal justice process. If victims had a role, it was as a witness. Unlike the legal systems of many other nations, the crime victim in the United States is not a party to a criminal prosecution. The prosecution is directed entirely by the public prosecutor. She may consider victim desires, but will ultimately make her own judgments in the case based on her assessment of the justice needs of the whole community. In the courtroom, American criminal justice is an adversarial process in which prosecutors and defense attorneys direct the action, subject to the rulings 
of the court. This structure often leaves victims sidelined. It was this experience that many victims' rights were designed to change. And in that regard, they have made some difference, though less than many hoped.

While victims usually have the right to notification of important case events, in many busy jurisdictions, victims find that accurate and timely information is a precious commodity. Sometimes they get it; sometimes they do not. Depending on the nature of the case and the police and prosecutors involved, victims may be consulted on plea bargains; often they are not. Many jurisdictions have victim service advocates, whose job it is to help victims access public services and understand the legal process. Many victims never learn about these services, however, and their quality is enormously variable, even within the same jurisdiction. Due to victims' rights legislation, surviving family members in homicide cases can almost always attend trials, where in the past they might have been excluded as potential witnesses. And victims gained a statutory right to speak at sentencing.

As a result of these rights and the awareness created by the victims' rights movement, prosecutors are more solicitous of victim views in serious cases than before. Judges are also more respectful of victims throughout the proceedings, but especially at sentencing. Police may be more respectful of victims as well. Still there remains a basic structural problem: how to fit third-party (victim) rights into an essentially two-party (prosecution-defense) system.

Generally, for a right to be effective, rights holders need lawyers to argue for the right. With very few exceptions, though, victims must rely on prosecutors to see that their rights are respected. This works fine when victim and prosecutor interests align, but poorly when they do not. ${ }^{15}$ Also, there is a problem here with remedy. Most victim rights are created by statutes that do not say anything about a remedy for rights violations. By contrast with defendant rights, where courts have determined that serious violations may lead to the exclusion of evidence, dismissal of charges or the invalidation of a conviction, it's not clear what happens, if for example, victims are not informed of important proceedings or not given a chance to speak at sentencing. In some instances, a proceeding may be ordered redone, but mostly there is no legal consequence.

There is one new victim right that is widely respected: the right to make a victim impact statement at sentencing.

\section{Moving from Legal Justice to Relational Justice: Victim Impact Statements}

Victim impact statements may be the most visible product of the victims' rights movement in the American courtroom today. In every state, victims have a right 
to provide personal statements to the sentencing authority. ${ }^{16}$ Such statements, often delivered orally, feature prominently in media coverage of sentencing in high profile cases. A public and legal consensus has arisen that such statements are a vital part of the criminal process in the courtroom today. But why? What role do these have in informing the sentencing judge about proper sentence? What other purpose might they serve as well?

\section{Origins of the Right in the Death Penalty: Payne v. Tennessee}

The right to give victim impact statements initially arose in death penalty cases, as a way for victim survivors to give distinctive emotional voice to their hurt and to support the prosecution's effort to win a death sentence. After an earlier decision held to the contrary, the United States Supreme Court authorized the use of victim impact testimony under the Eighth Amendment in Payne v. Tennessee in $1991 .{ }^{17}$

The prosecution's evidence at trial indicated that on the afternoon of June 27, 1987, after a day of drinking and drug use, Pervis Payne went to see his girlfriend Bobbie at her apartment building. She was supposed to be coming back that day from a week's visit with her mother in Arkansas, but twice before he had stopped by and found that she had not yet returned. Payne finally decided to knock on the door of the neighboring apartment which belonged to 28-year-old Charisse Christopher. They had met before. Apparently he was invited in. He then made sexual advances to her. When Charisse spurned him, the evidence indicated that Payne took a butcher knife from the kitchen and attacked Charisse, her two-yearold daughter, Lacie, and her three-year-old son, Nicholas. ${ }^{18}$ He killed Charisse and Lacie. Nicholas somehow survived despite enormous blood loss from numerous stab wounds, including a knife thrust that went through his entire torso. A man matching Payne's description was seen running from the scene. Payne was arrested later that day hiding shirtless in the attic of an acquaintance's house. Blood on his clothes matched that of the victims. The jury convicted Payne of two counts of first-degree murder and one count of attempted murder. ${ }^{19}$ The case then moved to the penalty phase to determine if Payne should live or die.

During the penalty phase, the prosecution called the homicide detective in the case to introduce a video which he had taken of the murder scene. The only other witness for the state in the penalty phase was Nicholas's grandmother, Mary Zvolanek. The prosecutor asked Zvolanek how Nicholas had been affected by the killing of his sister and his mother. Zvolanek said:

He cries for his mom. He doesn't seem to understand why she doesn't come home. And he cries for his sister Lacie. He comes to me many 
times during the week and asks me, grandmamma, do you miss my Lacie. And I tell him yes. He says, I am worried about my Lacie. $^{20}$

In his final arguments, the prosecutor urged the jury to vote for death so that when he grew up, Nicholas would know that justice had been done to the killer of his mother and sister. Responding to mitigating evidence introduced by the defense at the penalty phase, the prosecutor sought to switch the focus from Payne to his victims. The prosecutor complained that Payne's defense counsel:

... wants you to think about a good reputation, people who love the defendant and things about him. He doesn't want you to think about the people who love Charisse Christopher, her mother and daddy who loved her. The people who loved little Lacie Jo, the grandparents who are still here. The brother who mourns for her every single day and wants to know where his best playmate is. He doesn't have anybody to watch cartoons with him ... ${ }^{21}$

Justice William Rehnquist, writing for the Court's majority, held that the testimony of Nicholas's grandmother informed the sentencing jury about the extent of harm done by the defendant and thus went to the severity of his offense. The majority thought this important even though the grandmother had no direct information about either the crime or the defendant, which are usually the focus of sentencing. Rehnquist noted that in death penalty cases the defense is entitled to present evidence about the defendant as a "uniquely human being" to argue against a death sentence. ${ }^{22}$ Rehnquist asserted that the defense's opportunity to present such testimony about the defendant demanded that the prosecution have a similar opportunity to humanize any homicide victim. Without this, the victim might remain a "faceless stranger" to the sentencing jury, depriving the prosecution of the "full moral force of its evidence.",23

In dissent, Justice Stevens charged that the majority's approach privileged emotion over reason. ${ }^{24}$ And clearly the force of the victim impact testimony here, as in many cases, depended on its emotional effect. Which brings us to the central justice question: can victim impact statements further just sentencing even if their content is primarily emotional rather than factual?

\section{Victim Statements in Noncapital Cases: A Legal View}

Victim impact statements are most often used in noncapital cases, where judges rather than juries decide the defendant's sentence. Because judges are assumed to be 
less emotional than juries, concerns with the emotionality of victim statements would seem to be less in noncapital cases than where execution is a sentencing option. ${ }^{25}$ We might expect that judges, with their commitment to a judicial temperament and the rule of law, would not be swayed by the passions of victim speakers. Yet judges are human; they also may be moved by the expression of deep loss and anger. And even if they are not, there must be a justice reason for encouraging highly emotional statements in the generally dispassionate setting of the criminal courtroom.

Under law, the sentencing hearing serves to provide a forum for the presentation of relevant facts and legal arguments on punishment in the case. There are two ways that victim statements might help in this process. Victims might: (1) provide new factual information about the offense or offender, or (2) make a personal recommendation on sentence. Neither fully explains what happens with victim impact testimony in many cases today.

Victims in their statements may give judges important data about the case relevant to sentence. By virtue of their knowledge of the crime, victims may speak to the culpability or dangerousness of the offender or the severity of the offense. Particularly in cases of sexual violence, victims will know things about the crime and the defendant that no one else does. Victims may also be able to inform the court of economic losses which may be addressed in an order for restitution. But there are many cases (see Payne above) where victim speakers do not have direct information about either the offense or the offender. In these cases, the sentencing judge learns about the offense and offender almost exclusively through pretrial hearings, trial testimony (if any) and the presentence report in the case. Prosecution and defense attorneys may also provide relevant information in their presentations. As a result, victim impact statements usually do not add significantly to what the judge already knows about the case.

Another role for victims at sentencing might be to recommend a particular sentence. The lawyers in the case normally give the judge sentencing recommendations, the prosecutor on behalf of the state and the defense attorney on behalf of the defendant. The impact statement might give victims the chance to recommend a sentence independent of either attorney. Although this goes against the basic two party, prosecution versus defense, structure of American law, some US jurisdictions give victims a statutory right to state their sentencing preferences to the judge. This remains the exception, though. In many jurisdictions, victims are told not to give their opinions about sentencing length. ${ }^{26}$

Regardless of the right to recommend sentence, in all cases the judge must decide the sentence according to basic principles of justice for all. Giving victim recommendations special weight, particularly in cases of serious violence, could 
undermine the commitment to justice for all. Should a defendant convicted of murder be treated leniently just because a survivor desires this? Should a defendant convicted of robbery be punished more severely because his victim holds particularly punitive views on sentencing? Cognizant of this, most sentencing judges will listen respectfully to victim impact statements, but will generally seek to rest their incarceration decision on more objective grounds.

That victim impact statements are not, in many cases, about informing the judge about important facts or providing an independent sentence recommendation, becomes clear in those cases where the judge has little or no discretion in sentencing. Sometimes, by virtue of a mandatory sentencing law or the constraints of a plea bargain, the sentence is essentially preordained. And yet, even in these cases we often see lengthy victim impact hearings, sometimes lasting for days. Something else must be going on here.

\section{A Relational Understanding of Victim Impact Statements: Speaking Personally to Court, Community and Defendant}

We turn now from a legal understanding of victim impact statements to their actual practice. In practice, we find victims speaking personally, meaning emotionally, about their victimization. They speak primarily to the sentencing judge, but also to the defendant and the community at large.

In preparing impact statements, victims are told that this is their chance to tell their own story in their own words. Victims are told that statements should come from the heart and speak to the heart of listeners. Here are instructions to victims, from three different sources.

Your goal is to help the court feel your trauma. While nobody can truly understand what you are feeling, you can help others identify with your trauma by using feeling evoking words and phrases. ${ }^{27}$

Your goal is to help the court feel your loss. Your words will help others in the court understand your experience. ... Write and speak from the heart about your pain. $^{28}$

You should stay, "feeling focused" in your written victim impact statement. Your personal feelings of the effects of the crime can and should be in your statement. ${ }^{29}$

This is the language of psychotherapy, not law. Emotional expression may be essential to successful therapy, but it is generally discouraged in the courtroom where objectivity and dispassion are prized. How can speaking personally and 
emotionally be valuable to justice under law? The answer involves the difference between cognitive and emotional understanding.

From the beginning of our journey in search of justice for wrongful violence we have seen differences between cognitive and emotional understanding. The minimization, avoidance, and denial of evil that are so familiar in response to sexual violence testify to the inadequacy of cognitive understanding in at least some situations. As one victim of abuse recently noted, "[i]t's so hard (for people) to grasp what child abuse truly is. People understand what it is, but if you don't force them to have an emotional reaction to your words, it's not really going to sink in." 30

By speaking personally, victims can speak directly of the soul devastation of violence. They can give listeners a view of the dark land to which they have been exiled. Even if the speaker offers no new facts, the personal force of the spoken words may deepen listeners' understanding of the wrong done. For example, a woman who was raped said this in her impact statement:

I struggle to believe I have anything to offer my friends any more. I am not the person I was before the assault and I will never be the same as a result of what has been done to me. I struggle to remember what life was like when things like safety could be taken for granted. I am afraid I cannot live up to the expectations of those who knew me before. I struggle to connect to people in good faith and to trust them. I constantly wonder if the people around me mean well or mean me harm. I struggle to find the energy, on so many days, to fight through the difficulties sexual assault has created for me and reach out to others. Solitude and isolation too often seem like the safe option, the safest option and so, social isolation has become yet another reality of life for me since the assault. ... Sexual assault has cost me profoundly, in many ways, and has set my life on a completely different course from the one it would have taken, had I not been assaulted. I have lost so much and many of those losses cut right to the core of who I am and can never be undone. ${ }^{31}$

This is a more eloquent expression of the soul harm of rape than any professional advocate could make.

At their best, victim impact statements answer the worst effects of violence. Violence to the person is a powerful form of silencing; speaking at sentencing represents a recovery of voice.

Violence denies the victim's autonomy by making him an object of the perpetrator's choices, rather than an independent person with free choices to make. Speaking at sentencing, the victim publicly takes charge of his own life. 
Violent acts disregard the unique and valuable person of the victim. In speaking at sentencing, the victim asserts her unique value, in her own voice. The speaker can step out of the generic role of victim to be a sui generis person, valued for her own unique attributes.

Violence isolates. It takes the victim out of social belonging. Speaking in the courtroom, in response to a judicial invitation, represents a symbolically important recognition of the person's place in community.

These are some of the ways that victim impact statements might answer the moral disregard of criminal violence. But is this how they are actually used?

\section{Powerful Voices: The Sentencing of Dr. Larry Nassar}

In January of 2018, sentencing hearings in two state courtrooms in Michigan captured national attention. Over the course of seven days, a total of 156 women gave victim impact statements, telling how defendant Larry Nassar had sexually abused them under the guise of medical care. The story of what he had done fits the pattern that we saw in Chapter 3 of other cases of long-term sexual abuse. A trusted figure working in trusted institutions-here a doctor for a Michigan State University sports clinic and for USA gymnastics - used his access to vulnerable young people to commit sexual abuse. For years complaints about his conduct were ignored. Finally, attention began to be paid. The earliest victim to speak out publicly suffered skepticism and personal attacks from some, but she was heard. The dynamics of public understanding shifted. When an Indianapolis newspaper published extensive stories on the abuse, when law enforcement investigated fully and when both state and federal charges were brought against Nassar, the public tide turned powerfully against him. Then, everyone agreed that Larry Nassar's conduct was horrific beyond words. Then, the enthusiasm for blaming him and anyone who had failed to stop him, was great. ${ }^{32}$

In those Michigan courtrooms in the first month of 2018, the emotional floodgates opened. Victim speakers addressed the judge, the defendant, and the public. They expressed their hurt and their anger and their determination, in presentations that were broadcast and reported nationwide.

Your Honor, I ask you to give Larry the strongest possible sentence, which his actions deserve. For by doing so, you will send a message to him and to other abusers that they cannot get away with their horrible crimes. They will be exposed for the evil they are and they will be punished to the maximum extent of the law. Let this sentence strike fear in anyone who thinks it is OK to hurt another person. Abusers, your time is up. The survivors are here, standing tall, and we are not going anywhere. ${ }^{33}$ 
Victims raged at the defendant. "I can't even put into words how much I fucking hate you," said former US gymnast Mattie Larson. "34 "You are so sick I can't even comprehend how angry I feel when I think of you," said Aly Raisman. ${ }^{35}$

Many victims told Nassar they felt empowered speaking to him at sentencing.

Imagine feeling like you have no power and no voice. Well you know what, Larry? I have both power and voice and I am only beginning to just use them. All these brave women have power and we will use our voices to make sure you get what you deserve-a life of suffering spent replaying the words delivered by this powerful army of survivors. ${ }^{36}$

Victims warned Nassar that they would no longer be silenced.

Little girls don't stay little forever. They grow into strong women that return to destroy your world. ${ }^{37}$

The army you chose in the late 90s to silence me, to dismiss me and my attempt at speaking the truth, will not prevail over the army you created when violating us. ${ }^{38}$

A clear indicator that we have moved beyond the usual bounds of the sentencing hearing is who victim speakers address with their statements. If statements were just about the defendant's sentence, then we would expect speakers to address themselves exclusively to the sentencing judge. ${ }^{39}$ Yet here (and in other cases) victims address the defendant and the community as well as the court. They speak not just to what the defendant did, but to relationships past, present and future. Victims speak to reset relationships created by sexual abuse. I will say more about this kind of relational change in the next chapter. For now, it is enough to recognize that we face a new justice challenge here. The usual procedural rules for sentencing will not suffice, because these do not acknowledge the relational dimension of statement-giving. ${ }^{40}$

\section{Toward Relational Justice at Sentencing: Problems with Victim Impact Statements}

For all their popularity, victim impact statements remain controversial in American law. ${ }^{41}$ Although an established part of the legal process, their legal function remains poorly defined. Clearly such statements do something more than provide information or sentencing recommendations, but what is this something more? Is it consistent with doing justice? How do we prevent courtrooms from being converted into ersatz reality 
television sets, where personal attacks and extreme emotional displays are the norm? I suggest we turn once more to principles of moral regard.

Sentencing hearings should be conducted with moral regard for victims and defendants. Victims should have the chance to name the evil of what the defendant did. Defendant name-calling should be discouraged, however. Declaring the defendant a monster or animal, excrement or vermin may be an authentic expression of the victim's passion, but it violates the basic (and often challenging) principle that to do justice we must strive to recognize the nature and value of fellow human beings. That is the basic principle that criminal conviction and punishment defends. A sentencing hearing should not be an occasion for their violation. Or to put this another way, just punishment is not just payback. Court proceedings should not condone emotional violence any more than they should physical violence. ${ }^{42}$

Many have argued that victim impact statements overemphasize the need for harsh punishment. ${ }^{43}$ But there is an opposite worry as well: that victims who support lesser punishment will be silenced. In many jurisdictions, victim impact statements are prepared in coordination with prosecutors. Prosecutors often see these statements as part of their own advocacy at sentencing. But victim statements are supposed to be victim presentations. While many victims support the state's efforts to secure a particular sentence, not all will. In death cases, conflicts between prosecution and victim preferences about sentencing can be especially stark. ${ }^{44}$ In nondeath cases, prosecutors often seek to edit victim statements to better support the lawyer's sentencing argument. But if this is a victim's right to speak, then all victim voices should be heard. Victims who wish to speak in a merciful voice must be heard as well.

Finally, in hearing victim impact statements, judges must remind themselves that victims should not be judged worthy or unworthy. This is a temptation regardless of victim impact statements, but it can be exacerbated by differences in victim speakers and their speaking ability. Where articulate, powerful speakers appear, whose situations resonate personally with the sentencer, the loss from violence will be felt more than where speakers are less effective communicators, or come from a very different background, or when there is no one to speak for the victim. Differences in potential judicial responses according to speaker race and class and culture and gender and age need to be monitored. Both the need for sentencer humility, discussed in Chapter 6, and the need to guard against unconscious bias, the subject of Chapter 10 , come into play here. ${ }^{45}$

\section{Conclusion}

You think you're going to feel so much better once that person is arrested and convicted and sent to jail! You think life is going to get back to normal. 
Everything's gonna be okay; the slate's gonna be wiped clean or the scales will be even. And that is about the farthest thing from the truth. I went away from court, and in a couple of months I was probably in worse shape than before. ${ }^{46}$

In recent years, public officials have promised victims of violent crime in the United States a great deal. Victims have been promised new rights in the courtroom to counterbalance defendant rights. Victims have been promised that perpetrators will be severely punished. Victims have been promised justice by law.

But promise-making is a hazardous enterprise, as anyone in authority, from parent to President, soon learns. We should not promise what we cannot deliver, for the hurt and anger of the disappointed can be enormous. The promises made to victims of violent crime in recent years, I believe, have been overstated, and misstated, because they misrepresent and misunderstand what the law can and cannot do for victims.

The promise that public officials make to victims of violent crime that legal justice will be done in their cases is a noble one. It is one to which I have committed myself as a federal prosecutor, a teacher of law, and a scholar of criminal justice. But realistically, what promises can we make to someone who has been badly hurt by a fellow human being and is trying to decide whether to report it to the police, or who needs help managing a legal process already begun?

Can we promise a victim that she will be believed? In most instances, we cannot. American criminal law employs an adversarial process that tests all important sources of evidence. Survivors who have case-relevant information (and even some who do not) may be questioned closely, sometimes skeptically, even aggressively, and not just by defense attorneys in cross-examination at trial, but by police and prosecutors and others involved in the legal process. In many cases, victim credibility must be earned; it will not be assumed.

Can we promise that the victim will be treated respectfully by police, prosecutors and the courts, at least to the extent of being kept fully informed about the case? Again, the answer must be no. Law enforcement officers and courts in many jurisdictions are too overburdened, responsibilities for communication are too diffuse, and the competing demands for time and attention of other cases too great to guarantee timely communication with all victims. Survivors will often find themselves in the dark about the state of a police investigation, or when the next court hearing will be or what it will entail; they may even be confused about what is happening in front of them in the courtroom. Phone calls to police and prosecutors and others will often go unanswered, though victims are desperate for even the smallest bit of case information. 
Can we promise that if convicted, the defendant will receive a sentence commensurate with the severity of harm experienced by the victim? Once more, the answer must be no, because there are many other factors contributing to what is an appropriate sentence in the case.

For these reasons (among others) we should be cautious about what we promise victims by way of law.

In part to avoid disappointing victims and other needy individuals with whom they interact, many criminal justice professionals develop an emotional carapace, a protective shield around themselves to limit personal interactions. Such professionals stay entirely within their professional role. The police officer will take a "just the facts, ma'am" Joe Friday approach to victims, never deviating from the investigator's script. Prosecutors and judges and others may do the same, hewing close to the formalities of the legal process. This approach avoids over-promising, but at the potential cost of estranging victims.

A person who has been treated with serious moral disregard, who has had their uniqueness denied and their essential value trashed by a violent attacker, comes to law enforcement and the legal system with basic relational needs. He needs to be seen and heard and valued. Sometimes this happens in the courtroom. Whether it does or not, though, legal professionals can work to see and hear and value victims as persons. We should see this as justice work, because it answers the original wrong of the crime. Justice by rule of law is not the only form of justice we might seek.

\section{Notes}

1 Federal Bureau of Investigation, Uniform Crime Report, Crime in the United States, 2015, Offenses Cleared.

2 Id. Clearance rates for rape are especially suspect because of the demands that policeand to some extent prosecutors-place on the evidence needed to make an arrest. See Cassia Spohn \& Katharine Tellis, Justice Denied?: The Exceptional Clearance of Rape Cases in Los Angeles, 74 Alb. L. Rev. 1379 (2011).

3 US Dept. of Justice, Civil Rights Division, Investigation of the Baltimore City Police Department, August 10, 2016, p. 122 (comment made at a party attended by police officers and victim advocates, reported by a victim advocate).

4 US Dept. of Justice, Civil Rights Division, Investigation of the Baltimore City Police Department, August 10, 2016, pp. 122-7; US Dept. of Justice, Civil Rights Division, Investigation of the New Orleans Police Department, March 16, 2011, pp. 43-50; Human Rights Watch, Capitol Offense: Police Mishandling of Sexual Assault Cases in the District of Columbia, Jan. 24, 2013. The report may be found at https://www. hrw.org/report/2013/01/24/capitol-offense/police-mishandling-sexual-assault-casesdistrict-columbia. Mistreatment of victims also occurs in prosecutors' offices. See US 
Dept. of Justice, Findings Letter-Missoula County Attorney's Office-Feb. 14, 2014. This may be found at https://www.justice.gov/sites/default/files/crt/legacy/2014/02/ 19/missoula_ltr_2-14-14.pdf

5 Sandra D., who reported a sexual assault to D.C. police in 2011, quoted in Human Rights Watch, U.S.: D.C. Police Mishandle Sexual Assault Cases, Jan. 24, 2013, found at: https://www.hrw.org/news/2013/01/24/us-dc-police-mishandle-sexual-assault-cases.

6 Letter of Eleanor G. to Metropolitan Police Chief Cathy Lanier, concerning treatment by police after reporting attempted sexual assault in 2014, quoted in id.

7 See Erik Eckholm, No Longer Ignored, Evidence Solves Rape Cases Years Later, The New York Times, August 3, 2014, at 1. For an example of how police work in this area can and should proceed, see Kathy Dobie, To Catch a Rapist, New York Times Magazine, Jan. 5, 2016 (profiling the Special Victims Unit in the New Haven Police Department). For a close study of continued issues in policing and prosecution in sexual assault cases, see Spohn \& Tellis (2011).

8 For historical accounts, see Jill Lepore, Sirens in the Night: How the Victims'-rights Revolution Has Remade American Justice, The New Yorker, May 21, 2018; Jon Kyle, Steven J. Twist \& Stephen Higgins, On the Wings of Their Angels: The Scott Campbell, Stephanie Roper, Wendy Preston, Lourna Gillis and Nila Lynn Crime Victims Act, 9 Lewis \& Clark L. Rev. 581, 583-93 (2005).

9 For critical views of the connection between the victims' rights movement and tough on crime policies in America, see Markus Dirk Dubber, Victims in the War on Crime: The Use and Abuse of Victims' Rights (New York: New York University Press, 2002), pp. 1-10; Lynne Henderson, The Wrongs of Victim's Rights, 37 Stan. L. Rev. 937, 942-53 (1985).

10 In California, the most politically powerful victims group has been Crime Victims United of California, crimevictimsunited.com. The group has been a strong supporter of Three Strikes and other tough on crime laws. It has had close ties with the California Correctional Peace Officers Association, the politically powerful corrections officers' union that has generally taken a hard line on punishment policy in the state. See Joshua Page, The Toughest Beat: Politics, Punishment, and the Prison Officers Union in California (New York: Oxford University Press, 2011), pp. 81-110; Joe Domanick, Cruel Justice: Three Strikes and Politics of Crime in America's Golden State (Berkeley and Los Angeles: University of California Press, 2004), pp. 112, 250-2. See also National Organization of Victims of Juvenile Murderers (NOVJM) at www.teenkillers.org. The NOVJM says it takes no stand on sentencing in individual cases but it has mobilized against resentencing of juvenile murderers on the ground of the harm to victims in revisiting punishment issues. "We stand for the importance of giving devastated victims' families LEGAL FINALITY in their cases so that they do not have to spend much of the rest of their lives constantly having to re-engage with the person who destroyed their lives by murdering their loved ones" (NOVJM website, Sept. 7, 2017). Similarly, the National Organization of Parents of Murdered Children (www.pomc. com) is primarily a victim support organization. It does engage with punishment issues in support of member efforts to block parole for certain offenders. In recent years, victim groups with a more liberal agenda on punishment issues have arisen in the state. See Healing Dialogue and Action, healingdialogueandaction.org, and California Crime 
Victims for Alternatives to the Death Penalty, californiacrimevictioms.org. For an organization devoted to healing for survivors and others affected by homicide, see Healing Hearts, Restoring Hope, https://www.hhrh-la.org/.

11 See D. Finkelhor, H. Hammer \& A.J. Sedlak, Sexually Assaulted Children: National Estimates and Characteristics, in OJJDP: Juvenile Justice Bulletin, 2004, p. 2, found at https://www.ncjrs.gov/pdffiles1/ojjdp/214383.pdf.

12 James Alan Fox \& Marianne Zawitz, Bureau of Justice Statistics, Homicide Trends in the United States, found at https://www.bjs.gov/content/pub/pdf/htius.pdf.

13 During the period 2002-11, on average, blacks were 6.3 times more likely to be victims of homicide than whites. Erica L. Smith \& Alexia Cooper, Bureau of Justice Statistics, Homicide in the U.S., Known to Law Enforcement, 2011, December, 2013, found at https://www.bjs.gov/content/pub/pdf/hus11.pdf.

14 William McDonald, Towards a Bicentennial Revolution in Criminal Justice: The Return of the Victim, 13 Am. Crim. L. Rev. 649, 650 (1976) quoted in Wayne LaFave, Jerold Israel, Nancy King \& Orin Kerr, Criminal Procedure $\left(^{\text {th }}\right.$ ed. St Paul MN: Thomson West, 2016), sec. 1.5(k).

15 This may occur when victims support less punishment for the defendant than prosecutors seek. See, e.g., Sabrina Tavernise, A Vandal's Act, Met With Mercy, The New York Times, Aug. 27, 2017, p. 1 (victims of burglary and vandalism of a mosque supported a misdemeanor conviction for an apologetic defendant, while the prosecutor insisted on, and got, a guilty plea to a felony).

16 Victim Impact Statements, The National Center for Victims of Crime, found at http:// victimsofcrime.org/help-for-crime-victims/get-help-bulletins-for-crime-victims/victim -impact-statements. For an introduction to the legal literature critical of the use of victim impact statements, particularly in death penalty cases, see Susan Bandes, Empathy, Victims, "Closure," and the Sociology of Emotion. 72 Law \& Contemp. Prob. 1 (2009); Narrative and Victim Impact Statements. 63 U. Chi. L. Rev. 361 (1996). For a defense, see Paul Cassell, In Defense of Victim Impact Statements. 6 Oh. J. Crim. L. 611 (2009).

17501 U.S. 808 (1991), overruling Booth v. Maryland, 482 U.S. 496 (1987).

18 Physical evidence at the scene also indicated a sexual assault on Charisse Christopher. State v. Payne, 791 S.W. 2d 10, 13 (Tenn. S.Ct. 1990). This was not mentioned in the subsequent decision by the US Supreme Court.

19 Payne maintained his innocence, saying that another man fitting his description committed the crimes and that he got blood on himself and his clothing when he entered the apartment after the crime-then he fled, thinking he would be accused of it. 501 U.S. at $813-14$.

20501 U.S. at 814-15.

21501 U.S. at 816.

22501 U.S. at 818.

23501 U.S. at 825, quoting Gathers v. South Carolina, 490 U.S. 805, 821 (1989) (O’Connor J dissenting).

24501 U.S. at 866.

25 By their nature, life and death decisions are more likely to call on a sentencer's personal values, making them more emotional. They are also notoriously difficult to regulate by 
predetermined legal rules. The difference between the capital and noncapital context is important in assessing the value of impact statements both within the standard justice under law model and under any conception of relational justice. Much of the critical literature on victim impact statements, both in law and social science, has focused on their impact on juries in death cases. E.g., Bandes (2009), (1996); James R. Acker \& David R. Karp eds., Wounds That Do Not Bind: Victim-Based Perspectives on the Death Penalty (Durham, NC: Carolina Academic Press, 2006), pp. 141-201. Cf. Erin L. Sheley, Reverberations of the Victim's "Voice": Victim Impact Statements and the Cultural Project of Punishment, 87 Ind. L.J. 1247 (2012).

26 For example, see this advice to victims from a prominent victims' support group on victim impact statements: "Do not ask for a specific sentence for the murderer. This is the prosecuting attorney's job. He/she will include the sentence their office is asking for in their argument." National Organization of Parents of Murdered Children, Inc., Preparing a Victim Impact Statement, found at http://www.pomc.com/impact.html (hereinafter, Preparing a Victim Impact Statement).

27 Victim Support Services, found at http://victimsupportservices.org/help-for-victims/ victim-impact-statements/.

28 Mothers Against Drunk Driving (MADD) Victim Services, Victim Impact Statement Booklet, p. 8.

29 National Organization of Parents of Murdered Children, Victim Impact Statements, found at http://www.pomc.com/impact.html.

30 Emmanuella Grinberg, These Women Made You Understand what Larry Nassar Did to Them, CNN, Jan. 28, 2018, https://www.cnn/2018/01/27/US/nassar-victim-impa ct-stmts/index.html (quoting former gymnast Kyle Stephens).

31 Kate Ravenscroft, Victim Impact Statement, posted May 23, 2014, found at https:// 16impacts.wordpress.com/2014/05/23/victim-impact-statement/. This impact statement appears to have been given in court in the state of Victoria, Australia.

32 See Marisa Kwiatkowski, Mark Alesia \& Tim Evans, A Blind Eye to Sex Abuse. How USA Gymnastics Failed to Report Cases, IndyStar Aug. 8, 2016, found at https:// www.indystar.com/story/news/investigations/2016/08/04/usa-gymnastics-sex-abuse-p rotected-coaches/85829732/; Christine Hauser and Maggie Astor, The Larry Nassar Case: What Happened and How the Fallout is Spreading, The New York Times, Jan. 25, 2018. On the initial response to public reporting of Nassar's abuse, see Rachel Denhollander, The Price I Paid for Taking on Larry Nassar, The New York Times, Jan. 26, 2018.

33 Mahita Gajanan, "It's Your Turn to Listen to Me." Read Aly Raisman's Testimony at Larry Nassar's Sentencing, TIME, Jan. 19, 2018 (hereinafter Raisman VIS).

34 Natalie Musumeci, Nassar victim: "I f-king hate you," New York Post, Jan. 23, 2018.

35 Raisman VIS.

36 Raisman VIS.

37 Kyle Stephens victim impact statement, found at https://www.rt.com/sport/ 416195-victims-statements-larry-nassar/.

38 Tiffany Thomas Lopez victim impact statement, in Carla Correa \& Meghan Louttit, More than 160 Women say Larry Nassar Sexually Abused Them. Here Are his Accusers in Their Own Words, The New York Times, Jan. 24, 2018. 
39 In fact, some trial judges require that victims address only the court and no one else in giving their impact statements.

40 For an argument about the value of victim statements in expressing collective and relational harms, see Sheley (2012).

41 See, e.g., Lepore (2018); Susan A. Bandes \& Jessica M. Salerno, Emotion, Proof and Prejudice: The Cognitive Science of Gruesome Photos and Victim Impact Statements, 46 Ariz. St. L.J. 1003 (2014).

42 Sentencing proceedings in the Nassar case actually featured an instance of physical violence, as an angry father of a victim tried to attack the defendant in the courtroom. David Eggert \& Mike Householder, Associated Press, Judge Admonishes Victims' Dad who Charged at Nassar in Court, February 3, 2018, found at http://www.chicagotri bune.com/sports/international/ct-victims-father-attack-larry-nassar-20180202-story.html. For an example of victim name-calling, see the victim impact statements in the sentencing of serial killer Dennis Rader, in which the defendant was repeatedly called a monster, as well as social sewage, a rabid animal and a walking cesspool, found at http:// www.freewebs.com/thebtksite/sentencingtranscript081805_7.htm.

43 For a review of research suggesting that victim impact statements encourage jurors to support harsher punishment (relevant in death cases), see Bandes \& Salerno (2014), pp. $1035-6$.

44 See Andrew Cohen, When Victims Speak Up in Court-In Defense of the Criminals, The Atlantic, Jan. 24, 2014. The issue of whether family survivors and the right to speak in favor of a life sentence at the penalty phase of this death case was obviated conflict when the state allowed the defendant to plead guilty and receive a life without chance of parole sentence. Mark Hansen, An Admitted Murderer Seeks Justice in the Death of his Daughter, ABA Journal, August 2015, http://www.abajournal.com/maga zine/article/an_admitted_murderer_seeks_justice_in_the_death_of_his_daughter. For more on such conflicts, see Wayne A. Logan, Victims, Survivors and the Decision to Seek and Impose Death, in Acker \& Karp (2006), pp. 161, 173-5.

45 Alternatively described, judges should exercise their moral imagination at sentencing. See Susan A. Bandes, Moral Imagination in Judging, 51 Washburn L.J. 1 (2011).

46 Marcella Hammett, Permanent Heartache: Portraits of Grief, Hope, Survival and Life after Homicide (Huntington, NY: Kroshka Books, 1998), p. xxii. 


\section{8}

\section{VICTIMS AND RELATIONAL JUSTICE}

It is one thing to survive tragedy. Most of us do, in whatever fashion, go on. But how to latch onto the audacity and means to thrive? ${ }^{1}$

Justice answers wrong. To be just, our response to wrong must recognize the nature and severity of what was done. In this way, justice and wrong must align.

If wrongful violence constitutes a violation of law-and only a violation of lawthen legal determinations of guilt and punishment may be sufficient for justice. But if wrongful violence harms souls, if it damages and even destroys valued relationships, and if in profound and complex ways it harms the person's ability to form and keep close relationships, then justice must comprehend these harms as well. If, in the words of writer David Grossman, survivors of violence are "cast out to a land of exile," then justice might offer a means of return. ${ }^{2}$ We have seen that some of the most important harms of violence are not legal, but relational. A full and just response must be relational as well.

In Part One we confronted the emotional consequences of surviving violence: the numbness, the anger, the fear and the pain. We saw the sense of social isolation that victims experience. The surviving husband described in Chapter 1, whom I encountered in a North Florida courtroom, stood profoundly alone. His world had been blown apart when the most important relationship in his life-his bond with his wife-was destroyed. How might he heal, relationally? How might he belong again?

From the hard-won experience of many victims, we know that relational healing from violence is possible. Someone who has lost his place in community due to 
violent loss may find a way to belong and live again. This outcome is not certain. Much depends on the individual's hopes and desires, fears and choices, his mental and emotional resources. But it will also depend on community efforts.

This chapter is about how we can encourage relational healing by listening to and being with victims. We will encounter the importance of accompaniment and mourning. We will look at the varieties of victim acceptance that can help in relational change and healing. Finally we will look at how relational justice values may inform the work of those in law enforcement.

The discussion begins with personal understandings of relational healing. Only when we understand personally, and therefore emotionally, how the hurt may heal and return to belonging does it make sense to explore how criminal justice professionals may help victims heal.

\section{Healing Basics: What the Community Can Do}

Doing these three things will help relational healing for victims of violence:

Make safe.

Listen close.

Be with.

To make safe means to provide victims some assurance that they will be protected from future violence by the perpetrator and others like him. This includes a public determination of what happened to the victim and who did it. An extensive discussion of security is not needed here, however, because it was a main topic of the last chapter, and because it is so prominent in most public discussions of criminal justice. We are always talking about what is needed for public safety. The same cannot be said of the need to listen close and be with victims, however. These require considerable explanation and discussion.

To listen close means listening to the victim's story without a predetermined purpose, such as to investigate for litigation, to diagnose or to treat. It means holding the pain the victim expresses, and not pushing it aside. We have had a glimpse of this kind of listening in the discussion of victim impact statements. Sentencing judges should listen closely to victims even when their statements will not affect the sentence given.

Being with means being present with the hurt, emotionally and usually physically. While such presence may not sound like much, indeed may not sound like doing anything, that is not true. Being with is what we do when there is nothing else we can do. Its modesty is its magic. It is much harder, and also more powerful, than it sounds. 
The basics of relational healing-making safe, listening close and being withcome directly from our foundational principle of moral regard. In doing these three things we see the uniqueness of the victim and we care for his or her good.

\section{Listening Close: Seeing, Hearing, and Believing Victims}

Those who survive violence need to be heard when they tell of their victimization. This does not mean that every word they speak must be taken as true. Persons who have been badly hurt can also be badly mistaken. Some may lie about being hurt or how they were hurt. But what victims of violence expect, and have a right to expect, is that their testimony will find a sympathetic audience.

Like most of us, victims expect that should the worst happen to them, police and prosecutors will listen to their account with an open mind. They do not expect to be met with harsh, even threatening questions about their own character and motivation. They do not expect to have to produce incontrovertible proof of their own injury or its significance to be believed. Especially with sexual violence, and especially with female victims, this happens all too frequently. Similar issues often arise with domestic violence as well. ${ }^{3}$

\section{Being With Victims}

Being with the hurt can take many forms. Perhaps the most important are accompaniment and mourning.

\section{Accompaniment}

I said, "My name's Eddie. I'm a trooper that's assigned to you. I'm here for whatever you need. I'm not going to leave your side."4

I had a friend who would stop by every day. She wouldn't say anything. She would just hug me. And that was so important to me. She never had to say a thing. It was just that hug. Just [to] let me know. I'm right here for you. ${ }^{5}$

I struggled with the concept of accompaniment when it was first explained to me. I was taking part in a program called Clinical Pastoral Education (CPE) in which I would work as a chaplain intern in a hospital in the San Fernando Valley of Los Angeles. I and fellow students were to provide patients with what was called a ministry of presence. We were not to attempt religious conversions. We were not to impose ourselves on the unwilling. We were just supposed to be there for 
patients on our floors who might want some company. We were to stop by each new patient's room to see how they were doing and ask if they might want to talk for a bit. We were not to take it personally if our offer was declined, as in many cases (of course) it was. Just making the offer was important.

What I had a hard time understanding initially, but came to appreciate, was how much simply being there for-and with-another person could help. Sometimes the conversations I had with patients concerned the most important issues in life, including death, but often they were, at least on the surface, mundane. What mattered was the offer and experience of accompaniment in an often lonely and frightening place.

Victims of violence also need accompaniment. I have heard a friend, Rita Chairez, explain to one of my classes how she took up her work in victim accompaniment. She knew the hurt of homicide because two of her brothers had been killed, years apart. Her work with victims began with a young woman whose boyfriend had been shot and killed on the streets of East Los Angeles, near where Rita lived. The young man's body lay on the street while police processed the crime scene. The woman was distraught because it was a cool night and she thought her boyfriend would be cold. She just wanted someone to put a blanket over him but no one at the scene would do it. Because Rita knew someone to call higher up in the police department, she was able to get the slain man covered. Then Rita sat with this woman in her apartment, not saying much, just being there for her. Later the woman told her that it made an enormous difference.

Another example of accompaniment may be found in the response to the slaughter of schoolchildren in Newtown in December, 2012. That is where the first quotation which heads this section comes from. On hearing about the shootings, Jenny Hubbard rushed to Sandy Hook Elementary where her two young children, Freddy and Catherine went to school. She immediately saw Freddy, who told her: "Mama, I can't find Catherine." Jenny calmed him down, left him with a teacher and went to try to find her daughter. She already believed - her "mother's instinct" - that Catherine was dead. She went to the firehouse where parents were to reunite with their children if they hadn't found them yet. There she learned that Catherine had been killed. And it was there that Connecticut State Trooper Eddie Vayan approached her and said, "My name's Eddie. I'm a trooper assigned to you. I'm here for whatever you need. I'm not going to leave your side." He had been a trooper for all of three years.

Trooper Vayan helped make the travel arrangements so that her husband Matthew could make an immediate trip home from a business trip in Switzerland. Using a photo of Catherine, Vayan handled the official identification of her body. He insulated the family from the media and became a kind of big brother to Freddy. At Freddy's request, Trooper Vayan stood by Catherine's 
casket at her wake in full uniform. Assigned to the security detail on Freddy's first day back at school, he left the boy a note on his desk, with the trooper's e-mail and cell phone number. The two exchanged messages during the day. "It's a kindness in him that goes far beyond what anybody could ever expect," Jenny Hubbard said of Vayan. ${ }^{6}$

Accompaniment is mostly done by family and friends, but law enforcement has an important role here as well. At a minimum, law enforcement should return phone calls, texts or e-mails to keep victims informed even when there are no developments in the case. It's a matter of accompaniment. It's proof that victims still belong.

\section{Mourning}

Mourning is a practice widely misunderstood and frequently neglected in modern America. Mourning is the process of grieving a serious loss. It can be done collectively in a ritual of mourning such as a funeral or memorial service. It can also be done privately in both ritual and very personal ways. Mourning is important for the spiritual and emotional recovery of those who have suffered the death of important people in their lives. We should also mourn other significant losses such as the loss of a job, one's health, or a marriage. Certainly this includes the losses that come from violence. As we have seen, even when no one dies, serious violence takes a life because it takes an essential part of the person.

Certain extreme, well-publicized episodes of violence produce mass mourning. The bombing of the federal building in Oklahoma City, the attacks of 9/ 11, the Boston Marathon bombing, the Newtown shooting, the Parkland, Florida shooting - these produced losses that even complete strangers mourned. We are familiar with the spontaneous appearance of flowers and notes, stuffed animals and other objects as memorials, and all manner of remembrances online that follow mass violence.

Mourning respects and is patient with sadness. This is difficult for many Americans today. In the 19th century, when death by sudden illness was a regular feature of life, melancholy and sorrow were mainstream emotions, commonly expressed, and mourning was a familiar theme in popular culture. Today, sadness is often confused with depression, and in our entertainment, protagonists are more likely to respond to loss with retaliation than with mourning.

When someone has suffered a serious loss, we need to respect and be patient with the sadness that loss engenders. We need to resist the benevolent impulse to cheer up the sad, which may lead to saying stupid things like, it'll all be okay. Trying to move the grief-stricken out of sadness prematurely can disrupt the mourning 
process, which is necessary for healing. I will return to this theme later in connection with public officials' promises of closure for victims.

\section{Changing Victim-Offender Relations}

I hope you relive the image of you murdering my baby in your mind for the rest of your life ... I pity you. You are a failure as a father. You are a failure as a man. You are a failure as a human being. ${ }^{7}$

Mother of murdered five-year-old boy, speaking at sentencing to the boy's killer

We have seen throughout our journey, but particularly in the last chapter, the great anger that victims often feel, directed at violent offenders. This frequently finds expression in victim impact statements at sentencing. The ferocity of survivor anger can be disquieting, even scary. In person it can have an electric quality to it, the emotional equivalent of a downed power wire. You don't want to get too close for fear of getting zapped. And this anger can last, unchanged, for months, years, decades. How should we respond?

We have seen in previous chapters how victim suffering and anger has been used in the political arena to increase the severity of punishment in America. Prosecutors often use it in the courtroom to argue for harsh sentences for particular defendants. But if we are concerned about victim healing, shouldn't we be concerned about what extreme anger does to victims? At a certain point, doesn't rage become selfdestructive? Consider the many accounts that celebrate individuals who have survived victimization or adversity without becoming "bitter." I think of the saying that staying angry at someone who has hurt you is like drinking poison, believing that it will kill the harm doer.

And yet victims have the right to rage at wrongdoers. Who are we to judge them for hating those who raped, molested or robbed them or killed a loved one? Who are we to say that anger cannot express love for one lost, or provide a bulwark against despair? Who are we to criticize, we who did not protect them from attack and have not experienced what they have?

Victims must find their own way forward. Unsolicited advice from strangers will often be unwelcome and unhelpful. (How often do you heed unsolicited advice from strangers, especially about what you should feel?) And yet we need to stand ready to help, if opportunity presents. For this, we have the example of victims who have created new lives and who have, to greater or lesser extents, laid down the burden of great anger. Understanding their experience may give us ways to invite victims back to belonging. They may also help should we become victims.

Victim anger, whether other- or self-directed, often seems like a major obstacle to relational healing. As a result, it may seem that the problem is located in the 
victim. He or she needs to change his or her emotional state. But relational healing is relational. The return to belonging that relational healing entails is less about changing victim emotions than about changing relationships between victims and others, particularly between victim and wrongdoer. It is about ending or transforming the unchosen relationship that violence has forged between victim and offender. When that relationship changes, the emotional experience of victims will change accordingly.

\section{Unchosen Relations}

I hated the idea that he-this faceless pronoun-was now a presence in our lives and that she, in some sense, remained in his grasp. ${ }^{8}$

$A$ husband on the unidentified man who violently assaulted his wife

I share my life not with the girls and boys I grew up with, or the students I went to Syracuse with, or even the friends and people I've known since. I share my life with my rapist. He is the husband to my fate.?

A young woman who was raped at college

On September 14, 2010, the Los Angeles Police Department held a press conference to ask for the public's help in locating a recent parolee suspected of murder. The next day the Los Angeles Times published a photograph from the press conference, which the paper titled, A Mother's Anguish. Taken by photographer Brian van der Brug, it depicts Gail Cameron, whose daughter Cheree was murdered.

Gail Cameron stands near an easel that holds a mug shot of the murder suspect. LAPD Captain Justin Eisenberg moves to comfort her by placing a hand on her shoulder. Cameron wears dark sunglasses that hide her eyes but not the awful pain written on her face. She is in pain because her daughter Cheree was recently murdered. She was killed two weeks before she was to be married. Cameron is in pain because she has just heard that Cheree's likely killer has the same birthday as Cheree.

The photograph presents a striking illustration of the way that an act of violence can forge a close connection between wrongdoer and victim. Daughter and killer share the same birthday. How awful. Even when violence occurs quickly and the attacker is a complete stranger, violence can create a strong, even intimate connection between victim and offender that may last for as long as the victim lives. ${ }^{10}$ Obviously this kind of close connection is not what victims want.

Most victims want nothing to do with the offender. In fact, victim healing often depends on a severing, or sometimes a transformation of the connection between victim and offender. Victims who have managed this can teach us much about 
healing from trauma. They show how a return to belonging depends on accepting some painful relational truths.

\section{Acceptance of Life Lost}

That's what violence does. It separates you from yourself. You are not the person you once were. From then on, you have to remake yourself from a different place. ${ }^{11}$

I used to think that maybe in five years it'll be over, and I can get on with my life; but now I know I'll never get over it. I realize that I am who I am because of what happened, and knowing that allows me to move forward with my life. ... The best advice that I could give to someone who has [to deal] with this, is that they need to understand that this is something that you'll have to live with for the rest of your life. And once you accept that, then you can begin to heal. ${ }^{12}$

And I must say that I still have feelings of wondering, "where do I fit in? Where do I belong? What's my role in this big picture?" It's like nothing is ever the same; it's not secure and safe anymore. And I have resigned myself to the fact that this is the way it will be for the rest of my life. ${ }^{13}$

I have emphasized from the beginning that serious violence takes lives beyond those that are physically ended. Few want to accept this. Indeed, victim survivors are inclined to make defiant statements that begin with, I will never accept that .... And yet for most victims, accepting relational loss from violence is critical to healing.

Accepting relational loss means accepting that a past life cannot be resumed. The person who was raped will never be the man or woman, boy or girl, who lived prior to the assault. Unless the victim can acknowledge the reality of this loss and incorporate it into his or her personal identity, a new life will be impossible.

Another kind of acceptance may also be needed: acceptance of limited control. Being victimized is fundamentally an experience of losing control. We thrill to action movies because of the way that protagonists stay in charge despite facing apparently overwhelming threats. But this is not the norm for those who face violent threats. Mostly they find themselves helpless to stop the attack.

Those who survive violence often try to hold onto a sense of agency by engaging in elaborate what if thinking about what happened. The survivor imagines how everything might have changed with different actions or words or timing. If I had just done this, or not done that, then none of this would have happened. Most of us indulge in what if thinking following disastrous events, a sign of how deeply ingrained is the idea that we can direct our own lives through our decision making. 
With a few different choices, everything would have been different. But sometimes we have no control; sometimes our considered choices cannot affect the outcome of events in any predictable way. The truth is we are much less the authors of our own lives than we would like to think.

Finally, many victims find relief when they can accept limited responsibility for doing justice. The victim may come to see that bringing the wrongdoer to justice, in whatever form that might take, is not his or her personal responsibility. It can be left to the law, or to fate, or to God. Acceptance means that the survivor's love for the murdered son or daughter, parent or spouse, sibling or friend need not be shown by pursuing his suffering.

\section{Acceptance of Offender Humanity}

I don't forgive him, but, you know, he's a human being. You have to move on. ... it's just as simple as that. ${ }^{14}$

A woman on the man who raped her years before

Earlier I described a photograph of an agonized Gail Cameron, whose daughter had been murdered two weeks before her marriage. The suspect, Omar Loera, was later arrested and charged in the case. He pled guilty to first-degree murder and received a life sentence. At the sentencing hearing, he read a brief statement of apology to the family and loved ones of the woman he killed, Cheree Osmanhodzic. He said he took responsibility for what he had done. "I will pay in full. I would give my life ... if I could bring her back. I can't do that."

The man who was engaged to marry Cheree, Adam Culvey, said nothing at the hearing, but after making eye contact with Loera, Culvey told his father, "Dad, all I feel is hurt and compassion for that man." The father related this statement to the sentencing judge, adding for himself, "As a father, how great is that - that now my son who has been through tragedy enough is not going to live his life in hate and vengeance?" 15

Through acceptance of Loera's humanity Adam Culvey created relational distance between himself and the killer of his wife. He refused the anger that can bind offender and victim together.

\section{The F Word for Victims: Forgiveness}

So what about forgiveness?

You can't go long in any contemporary discussion about healing from trauma, without some mention of forgiveness. Forgiveness can transform painful relationships, 
and so holds great promise for relational healing. Commensurate with its power to heal is its potential to hurt, however. That is why I call it the F word here.

Proponents say that forgiveness is vital to healing from trauma. Anger and fear should be exchanged for love, hostility for embrace. If you are hurt, you should forgive the one who hurt you. But the context for forgiveness matters. It matters what the wrong was. It matters what the previous relationship was between you and the wrongdoer. The wrongdoer's present attitude may matter. Most important of all, it matters why forgiveness is considered. Is forgiveness a purely therapeutic good? Or does it have something to do with justice? As always, our main concern is with justice.

Forgiveness is not part of justice under law. Forgiveness by the victim does not change a wrongdoer's liability or what punishment is appropriate according to general punishment principles. Forgiveness is not necessary to either justice under law or relational justice. It is not required for a community to call out the wrong and to bring those who were hurt back to belonging. It's only because forgiveness can be such a powerful instrument of healing that we consider it here.

Legal philosopher Jeffrie Murphy calls forgiveness a change in feeling and attitude toward the offender comprised of "the overcoming, on moral grounds ... of the vindictive passions of resentment, anger, hatred, and the desire for revenge."16 To forgive a wrongdoer means not just to renounce anger at him or her but to care for the wrongdoer's good. At its best, forgiveness works a kind of moral and emotional alchemy, converting anger, fear and disgust into concern, compassion and even love.

We know about forgiveness mostly from our close relationships: from friends, family, partners. Forgiveness can save a valued relationship threatened by a hurtful action. But forgiveness can also occur between persons who previously (before the wrong) were strangers.

For some victims, forgiveness is key to living again. For others, talk about forgiveness feels like salt sprinkled in open wounds. This is why we need to be so careful with forgiveness talk.

\section{Misunderstanding Forgiveness}

Forgiveness is frequently misunderstood. Here are a few of the most common misunderstandings.

Forgiveness cannot be demanded or expected. It is a gift that must be freely given. Even if it is good to forgive, an expectation of forgiveness tarnishes its rewards. In the case of wrongful violence, expecting victims to forgive can deepen the victim's isolation by showing how others don't understand. For these reasons many victims of violence bristle at any expectation of forgiveness for a perpetrator. ${ }^{17}$ 
Forgiveness need not depend on a wrongdoer's apology or confession. A sincere admission of responsibility and expression of remorse by the wrongdoer obviously makes forgiveness easier. Many people believe it is a prerequisite to forgiveness. But forgiveness can happen without apology or confession. ${ }^{18}$ Recall that we are concerned with forgiveness as a way to change the victim-offender relationship. Many who have forgiven their wrongdoer describe the decision to forgive as entirely self-interested. I did it for myself, not him. Indeed, a victim might forgive the wrongdoer without ever communicating that to him or anyone else. The act of forgiveness can be completed within the heart of the person who was wronged.

Forgiving does not mean forgetting the wrong done or the pain suffered. Forgiveness does not change what happened. Its reality and the pain it caused remain. Forgiveness does not erase the memory of what happened. Nor does it in any way excuse the wrongdoer from moral or legal responsibility. Forgiveness may change a victim's view of just punishment, but it also may not. The one who forgives may believe that significant punishment is merited for all of the generally accepted reasons given for punishment. Often, the forgiver will simply leave the question of punishment to others.

For most people, forgiveness is a process. Although many describe the decision to forgive as a one-time decision, it commonly takes place in stages. It may also require regular renewal. Yesterday the victim may have felt forgiveness, but today, anger is back in force. In this respect, forgiveness is like any other decision or emotion; it is subject to later revision.

\section{It Can Happen in Court: Defendant Confession and Apology}

I've had people ask me what it would take to bring me peace, because there is no peace. I would take a confession. That's what it would take for me. Nothing else really matters. ... A conviction is not enough. The death penalty would not be enough for me without a confession. ${ }^{19}$

Brother of murder victim

Conviction and punishment matter to victims, but often what they really want is to hear the defendant admit wrong and apologize. This by itself can fundamentally change the victim-offender relationship. Within the span of three weeks in the summer of 2015, this happened in two cases in Los Angeles courtrooms.

\section{Case One}

On her birthday in 2013, 39-year-old Rebecca Stafford got into a heated argument outside her Los Angeles home with a woman who objected to Stafford feeding 
stray cats in the neighborhood. The woman's adult son, Ian Eulian, intervened. He became angry on his mother's behalf and struck Stafford. He punched Stafford repeatedly, knocking her unconscious. Eulian was later arrested and criminally charged.

As the case proceeded through the courts, Stafford suffered lingering neck pain. She also was fearful. She avoided the market in her neighborhood for fear she might encounter Eulian. Then during the sentencing hearing in the case, defendant Eulian turned to Stafford and whispered: "I'm sorry."

"Thank you," Rebecca Stafford replied.

Addressing the court, defendant Eulian expressed remorse for what he had done and said that in the incident, "my emotions got the best of me."

In her remarks to the judge, Stafford thanked Eulian for his apology and said that she also understood what it was like to lose one's temper. She said that her longstanding fear of Eulian had disappeared with his apology. She did not have a recommendation to the court about whether he should serve time in jail. In fact he was sentenced to 180 days in jail, in addition to a term of probation, community service and anger management classes.

Outside of court, Stafford told a reporter that Eulian's unexpected apology to her had changed her entire perspective on the case. "That's kind of what I wanted from the beginning," she said.

\section{Case Two}

Los Angeles Police Department Officer Mary O'Callaghan, a former Marine and an 18-year veteran of the police department, was convicted of assaulting 35-year-old Alesia Thomas during the course of an arrest. The dashboard camera in her patrol car recorded the interaction between O'Callaghan and Thomas as Officer O'Callaghan worked to secure the arrestee in the back of the car. Thomas stated at one point, "I can't move. I can't breathe." According to newspaper reports, Officer O'Callaghan can be seen in the video striking Thomas in the throat with an open hand and jamming her boot into the woman's crotch three times. O'Callaghan is later seen on camera smoking a cigarette on the street. Realizing that Thomas has fallen unconscious, she remarks "that ain't a good sign."

An ambulance was called for Thomas about 30 minutes after Thomas first asked for help. She was pronounced dead shortly after arriving at the hospital. The coroner's office described cocaine intoxication as a "major factor" in Thomas's death. No determination could be made about the possible contribution of police actions to her death. ${ }^{20}$ 
At O'Callaghan's sentencing, Sandra Thomas, the mother of victim Alesia Thomas, criticized the defendant for her callousness. "You have to show compassion for people. ... It makes me feel like she [O'Callaghan] wanted that to happen."

When it was her turn to address the court, defendant O'Callaghan instead turned to Sandra Thomas and said, through tears: "Mother to mother. I am extremely sorry for the loss of your daughter." 21 O'Callaghan is a mother of three. Later O'Callaghan moved toward where Sandra Thomas was seated in the courtroom, but was blocked by courtroom bailiffs. O'Callaghan asked the judge, "Can I give her a hug?" The judge replied: "No hugging. Cannot be done."

After the proceeding, Sandra Thomas told a reporter that she was satisfied with the sentence of 16 months that O'Callaghan received and with O'Callaghan's expression of remorse. "I feel a great sense of relief," Thomas said.

The apologies in these two cases clearly meant a great deal to the victims and defendants involved. What happened seemed to resonate with observers as well. Yet nothing of legal significance occurred. The exchanges did not affect guilt or punishment. What happened was purely relational. With the defendant's apparently sincere apology, and its acceptance by the victim, their relationships fundamentally shifted. The soul wounds of a beaten woman and a surviving mother were recognized and lamented. A state of unjust and unchosen relations between victim and offender was transformed, at least for a moment, into relations of moral regard.

When events like this happen in court, they often seem miraculous, the result of extraordinary circumstances. But that, I think, says more about our expectations for justice than about its actual possibilities. Consider: most defendants plead guilty. A significant percentage are remorseful. Many victims would like to hear them apologize, personally. Given this, why should an in-court, personal apology be an extraordinary event? The answer has to do with the law's understanding of justice. In many cases, it's just too small. ${ }^{22}$

\section{Relational Justice Values for Prosecutors, Judges and Public Officials}

I am familiar with the polite silence with which criminal justice professionals often receive my, and others', urgings that they incorporate concerns with victim healing into their work. Whether spoken or not, conscious or not, I know what many are thinking: that's not my job. I say it should be.

In this last section I suggest how a commitment to relational justice for victims might shift the priorities and practices of three different groups: prosecutors, judges 
and public officials. This is just an introduction to the possible interaction between relational justice and legal justice. I do not address several critical professional groups, most notably police, probation officers and defense attorneys. And with each group that I do address, I make only one basic suggestion for change, either affirmative or negative. My aim is modest: to show how some victim needs for healing might be addressed within the legal process.

\section{Prosecutors: Being with Victims}

Victims want prosecutors not just to do their job, but to care. They want prosecutors to be with them on their journey. They hope that prosecutors will show concern for their pain. They expect close listening. Here are some representative comments of surviving family members in praise of the prosecutors who sought justice on behalf of a murdered love one:

The prosecutors had great compassion for us. ${ }^{23}$

The assistant DA did a very thorough job. [He] understood what was going on and he was able to express some of our anger at the injustice of the murder [to the jury]. ${ }^{24}$

Many contemporary prosecutors understand the need for an emotional bond with victim families in homicide cases: "I think it's real important [that] they do have a bond and [that] they trust the [prosecutor]. If you do go to trial, they need to trust that you really know what you're doing, that you really care, and that you're there to help them.",25

Sometimes prosecutors and victims bond naturally, without conscious effort on the lawyer's part. Prosecutors find they very much want to be with surviving victims, from start to finish. The murder of a mother in a strong middle class family, the rape and beating of a junior high teen on her way home from soccer practice, these are cases where many prosecutors will strongly empathize with victims. But if the victim was involved in drugs or prostitution or gangs, or the victim's family is dysfunctional, if there are significant race and class differences between victim and prosecutor, these will make an emotional connection difficult. In such cases, prosecutors mostly keep their emotional distance from victims. If asked, prosecutors will likely say (and believe) that they are just being professional. Their job is about convictions and punishment, not handholding. But notice the difference in relational treatment, a difference that victims will sense immediately. Why should some victims get justice under law and relational justice, while others get only law ${ }^{26}$ 
Perhaps the biggest obstacle to prosecutor-victim connections is the raw emotionality of victims. This can threaten the emotional stability of prosecutors, as it may threaten the emotional stability of other criminal justice professionals. Victim pain and suffering seems to have no end.

What I feel is that most people are so afraid of being victims themselves that when they are dealing with a victim they treat us as anathema. Our very existence makes them uncomfortable. I imagine I look like someone you know. Maybe I look like someone you love? I might make you feel uncomfortable just by my existence. Rape happened to me. It wasn't nice. It wasn't midnight, and I wasn't alone around the bar. I didn't ask for it.

This makes people uncomfortable. I would ask prosecuting attorneys not to hide behind sarcasm here, nor employ the games of the law, not to be afraid of being somehow compassionate, not to confuse cold with professional. ${ }^{27}$

Rape survivor testifying before Congress

Emotions are contagious and powerful emotions are powerfully contagious. Like other lawyers, many prosecutors develop a cool demeanor to help them engage highly emotional people without being emotionally affected themselves. The problem is that appearances have a way of becoming reality. It is actually quite difficult to appear emotionally disengaged without actually being emotionally disengaged.

Finally, prosecutors like all lawyers, have limited time to do their work. Being with and listening close to victims is time-consuming. To a harried prosecutor it will often seem like time wasted. How many times do I have to listen to her say the same thing? I need to get back to work. But if prosecutors can grasp the importance of close listening and being with for victim healing and if they can see how victim healing can be part of a larger justice, then time spent doing this looks much more valuable. It starts to look like a very important part of the job. ${ }^{28}$

\section{Judges: Guilty Pleas and Personal Acceptance of Responsibility}

If you have ever seen a defendant plead guilty in a criminal courtroom, you know that this is a scripted enterprise, in which there are certain things that the judge must say, that defense attorneys and prosecutors must say, and that the defendant must say. It is a legal ritual of rights proclaimed and waived. Given that this procedure provides the only public determination of the defendant's guilt in most cases, one might expect that there would be significant time devoted to what the defendant did wrong. We might also expect the defendant to take personal 
responsibility for wrongdoing. Both of these happen on occasion, but more often the plea ceremony is entirely ceremonial, without any personal admission of responsibility by the defendant. This does not comport very well with the truthtelling and truth-determining needs of victims, and of the community.

The judge that I clerked for, US District Court Judge William Matthew Byrne Jr, would always ask defendants at the plea ceremony a simple question: "What did you do?" He insisted that the defendant answer this question personally, not his attorney. And if the defendant could not or would not admit to facts that constituted the crime charged, the judge would set the case for trial. This practice was consistent with federal law, which requires the defendant to provide a factual basis for a guilty plea. By contrast, in California state courts, the factual basis can be provided by a stipulation (an agreement by the lawyers) or a summary of a police report or the legal charge, followed by acquiescence by defendant or defense attorney. There is usually no personal taking of responsibility by the defendant. I have been told by state court judges that there is no time for this. And certainly state judges in busy urban jurisdictions face huge pressures on their court time. I also realize that plea bargains are easier to reach when defendants do not have to condemn themselves in public. It's why corporations will pay millions and even billions to plaintiffs to settle cases without any public admission of fault.

But in a criminal case where there is no trial, a defendant's personal admission of wrongdoing serves important justice needs for both victims and the community. ${ }^{29}$ In relational justice terms, clear personal admissions of guilt both validate the victim's experience of being wronged and help restore her sense of moral order. It helps when the defendant admits that what she did was bad.

\section{Public Officials: Resisting the Siren Call of Closure}

Finally, a commitment to relational justice may tell us what we should not do in responding to criminal violence.

Public officials often promise that legal events such as arrest, conviction or sentence will bring a measure of closure for victims. Public officials thereby express the hope, and impliedly they promise, that victims will feel better, and be better able to move on as a result. The problem is, there is no such thing as closure for victims. It's a word that applies to legal cases and physical wounds, but not to the soul harms that victims suffer.

Generally we use the verb to close with things and not people. Roads and stores are closed. We close bank accounts, files and cases. We do not close memories of loved ones or feelings like sadness or anger. No one leaves a funeral service feeling that there has been "closure" with respect to the deceased. Not if it is a loved one. 
We also close physical wounds with stitches and bandages. This facilitates healing. But while one may fully recover from a physical wound, there is no returning to the life taken by violence, whether the life was taken physically or in spirit.

Because both the public and the criminal justice system are very concerned with closing criminal cases, the concept of closure is enormously appealing to public officials. It seems like something concrete we can offer victims. ${ }^{30}$ But closure is not a victim benefit. We feel better when some part of legal justice has been accomplished. We feel like we can move on. We should not claim this as a special good for victims. In fact, some victims will be hurt and angry after hearing public officials suggest that their deep hurts have been eased, when that is untrue. It's just more evidence that no one really understands.

I do not mean to say that signal accomplishments in a criminal investigation, like the discovery of a body, or the arrest of a suspect provide no relief to survivors of violence. They do. There can be relief in knowing: with the discovery of a body, we learn basic facts of what happened. There is another kind of relief, a moral relief, with an arrest, which brings the promise that the person who did great evil will not escape all consequences. I think of the 2018 arrest of the socalled Golden State Killer in California, a former police officer who authorities believe committed hundreds of burglaries, many rapes and a number of murders across California, without ever being identified before. Law enforcement's gathering of DNA and other evidence against him must count as a great gift to victim survivors, as well as the rest of the public. ${ }^{31}$ I just think public officials should avoid the word closure in describing this gift. Because events like these, however welcome, actually resurrect old pains. They may help in the grief and survival process, but they do not end the hurt.

And so for public officials tempted to speak of closure, I would advise: don't. This is not something in your power to provide or promise.

\section{Conclusion}

I have studied justice for crimes of violence for many years, and always thought that I knew how to respond to victims. But knowing how and actually doing it are quite different things.

In 2011, I was asked to speak before a state legislative committee on behalf of a bill that would allow juveniles who were given a life without chance of parole sentence (LWOP) to petition for a reduced sentence: 25 years to life. Almost all had been convicted of first-degree murder. I spoke to the committee for the allotted two minutes, following my prepared script, as did others who supported the bill. Later a speaker appeared who opposed the bill. She told how her adult 
son, a police officer, had been killed in the line of duty by two teens. The teens were convicted of murder and were currently serving LWOP. Although I am sure she had told her story many times, the passion and pain of her account made it powerful. She believed that there should be no change in current law, that LWOP sentences should be legally inviolate. She saw this as necessary for public safety and basic justice.

Later that day, as I was waiting in the Sacramento airport for my flight back to Los Angeles, I saw this speaker standing at the far end of the waiting area. It seemed as if we were both on the same flight back to LA. And I thought, I should go over and speak to her. I should introduce myself and say something about how even if we disagreed on the bill, I felt for her loss. Or just that I was sorry for what happened to her son. But I was tired, it had been a long day, and I certainly did not want to make things worse for her. This is what I told myself, rationalizing. I did not go over and I kept my distance getting on the flight. But I felt guilty about it.

Some time later I shared this experience with my friend Rita Chairez, who had also testified in favor of the bill that day. (Although a homicide survivor herself, having lost two brothers to murder, she favored the legislation.) I told Rita that I felt that I should have said something to the speaker at the airport. I hoped that Rita would give me some form of absolution. Instead she gave me the truth.

"You should have, Sam. Absolutely."

And then she shared that after the committee hearing, she had seen this speaker go into the ladies room in the statehouse building, just as she (Rita) was coming out. So Rita turned around and went into the ladies room again and spoke to her, to offer her support. They embraced, two victim survivors of terrible violence.

Victims of violence belong to us. ${ }^{32}$ Whether they look like us, whether they are like us, whether we like them as people, whether we agree or disagree with them on politics or policy, whether they are "innocent" victims in our eyes or not, whether the violence was recent or long ago, they belong to us. When we have the chance, we should listen to them closely and be with them. On that day, I failed to do what I should have done. Nor was this the only time that I have not listened close or been fully present with someone who has been hurt by violence. Knowing the right thing to do and doing it are very different. It's why I am so impressed when I see someone doing it right.

There was a photograph in the Los Angeles Times on August 27, 2015 that showed someone doing it right. In the photograph, two women speak across the top of a fence, yellow police tape in the foreground marking the boundary of a crime scene. On the left is the sister of a murder victim, her face twisted in grief. To the right, an LAPD sergeant has reached over the fence to hold her hand, seeking to comfort her. Both are African American women. ${ }^{33}$ This is not the usual 
image of police at work, not in what this officer is doing, or in gender or race. Nor does the grieving sister look like the headline victim of modern American culture. But the photo does show what relational justice can look like in America today.

Unfortunately the article that accompanied the photograph sent a very different message. An unbylined story beneath the photo said that two men had been shot to death the day before on a South Los Angeles street. One of those killed was this woman's brother. The paper gave the double homicide a grand total of six sentences. The account appeared in a compendium of other brief news items detailing the death of a whale in an Oakland waterway, the theft of a gun from a police officer's car in Oakland and a mountain lion's attack on a poodle in a Burbank backyard. ${ }^{34}$

If this is any indication of the degree of public concern about the murder of these men (and likely it is), how much keeping safe, listening close, or being with those who grieve their loss is likely to follow in the days, weeks, months and years to follow?

We must acknowledge and respect the needs of all victims for relational healing. This is essential to doing justice.

\section{Notes}

1 Charisse Coleman, Matters of Life and Death, in James Acker \& David Karp eds. Wounds That Do Not Bind, (Durham, NC: Carolina Academic Press, 2006), p. 28.

2 Woman, in David Grossman, Falling Out of Time, trans. Jessica Cohen (New York: Knopf, 2014) p. 19.

3 See American Civil Liberties Union, Responses from the Field: Sexual Assault, Domestic Violence, and Policing, October, 2015, pp. 1-2. Found at www.aclu.org/ responses/fromthefield.

4 Scott Pelley, A Guardian Angel Helps Family Heal in the Aftermath of Newtown, March 27, 2013, CBS News.

5 Marcella Hammett, Permanent Heartache: Portraits of Grief, Hope, Survival and Life after Homicide (Huntington, NY: Kroshka Books, 1998), p. 34.

6 Among the best descriptions of accompaniment is found in Charisse Coleman's essay, Matters of Life and Death: "What would happen if we changed our message to families shattered from violence from: 'Here, let us help you get over this,' to: 'We are here with you. We offer our presence for the duration of your pain and anger. We honor the strength and truth of those feelings. We are here to help to keep you from losing yourself in sorrow, and we will be here when you're able to step more fully into yourself as the weight of sorrow begins to lift." Acker \& Karp (2006), p. 20.

7 Nicole Santa Cruz, After Killing his Son, a South Pasadena Man Enjoyed Vegas Shows and Skydiving. Now He Is Heading to Prison for Life, Los Angeles Times, August 23, 2017.

8 Jamie Kalven, Working with Available Light: A Family's World After Violence (New York: Norton 1999), p. 43. 
9 Alice Seybold, Lucky (New York: Back Bay, 2002), p. 53.

10 As noted in Chapter 1, we do not think of negative connections with others as relationships, but they are. And they can prove to be close relationships in emotional terms. As a mundane illustration, think of those heated, on the field arguments that we see between a player and referee in soccer, or in baseball between a team manager and home plate umpire (more common in the days before instant replay). The angry litigant "gets in the face" of the official, and verbally they go "toe to toe." The men stand as close to each other as is possible without touching. We might even say they get in kissing range, which is normally unthinkable, socially. It's a moment of intimacy, inspired by rage.

11 Terri Jentz, Strange Piece of Paradise (New York: Picador, 2006), p. 514.

12 Hammett (1998), p. 51 (account of Lisa Rayam).

13 Hammett (1998), p. xxii.

14 Seybold (2002), p. 222.

15 Jack Leonard, Man Gets Life for Fatal Stabbing, Los Angeles Times, June 15, 2011.

16 Jeffrey Murphy, Punishment and the Moral Emotions: Essays in Law, Morality, and Religion (New York: Oxford University Press, 2012), p. 6, a conception of forgiveness that Murphy takes from a 1726 sermon by Bishop Joseph Butler "Upon Forgiveness of Injuries."

17 For a particularly sharp example, see Kathleen Sheeder Bonanno's poem Communion, in a book of brilliant poems Bonanno wrote about the murder of her adult daughter. She describes a minister offering forgiveness like a communion wafer, "because, after all, he must," and her responding with an angry toast of wine: "Here's to hate, you say,/ slugging it back,/eyeing the dregs." Slamming Open the Door (Farmington, ME: Alice James Books, 2009), p. 45. On social expectations that victims should forgive, see Charisse Coleman in Acker \& Karp (2006), p. 20.

18 For an example, see Marisa Gerber, A Cathartic Confrontation in Courtroom, Los Angeles Times, Sept. 24, 2014.

19 Hammett (1998) (Ray Adams following the murder of his sister), p. 133.

20 Police originally went to Thomas's house to investigate her for child abandonment. Thomas had earlier left her two children, aged 3 and 12, at a police station with clothes and a note that indicated she felt she could not care for them. Kate Mather, City Will Pay \$2.5 Million in LAPD Beating, Los Angeles Times, Oct. 16, 2015.

21 Javier Panzar, L.A. Officer Sentenced in Taped Assault, Los Angeles Times, July 24, 2015, at A1.

22 For a thoughtful look at apologies in the law that goes well beyond the issues discussed here, see Nick Smith, Justice through Apologies: Remorse, Reform, and Punishment (New York: Cambridge University Press, 2014).

23 Sarah Goodrum, Bridging the Gap Between Prosecutors' Cases and Victims' Biographies in the Criminal Justice System Through Shared Emotions, 38 Law \& Soc. Inquiry 257, 269 (2013).

24 Id. at 274.

25 Id. at 276.

26 One may also wonder how much legal justice such victims receive. Prosecutors will be much more vigorous in the prosecution of a case where they care about the victims than in cases where they do not. 
27 Senate Hearings at 65-66, quoted in Lynne N. Henderson, The Wrongs of Victim's Rights, 37 Stanf. L. Rev. 937, 1021 (1985).

28 The forms that relational justice values can take in prosecution work can be surprising. Several years ago one of my law students told me a story about working as an extern in the LA District Attorney's Office in a section of the office that handled sex crimes. Jeff, my student, was a cheerful young man in his 20 s with an infectious enthusiasm for the law and doing justice. His easy manner and lack of pretension put others at ease. The case involved allegations that a family member had committed sex offenses against a young teenage girl. Jeff was in the courtroom sitting at counsel table with the prosecutor on the case when the girl testified. The girl had held up well so far, but in lengthy crossexamination, she became agitated. Under hard questioning by the defense attorney, it appeared as if this teen, testifying about her sexual violation by a family member, was going to lose her composure completely, with potentially devastating effects for the case. She glanced across the courtroom at Jeff, who she knew from pretrial preparations. They made eye contact and Jeff decided to make funny faces at her. Like a big brother acting goofy to make his kid sister laugh, he used his tongue to bulge out his cheek and made other odd expressions, inspiring her to smile and giggle. After this she got her breath back and continued with her testimony, once more in control. At the recess of court proceedings for the day, she gave Jeff a big hug and said that she couldn't have done it without him. I think this was an example of relational justice, prosecution-style.

29 On a related point, in California courts it is common for defendants to plead no contest rather than plead guilty. A no contest plea has the same legal effect as a guilty plea but the defendant need not say that he or she is guilty. The no contest plea has the legal advantage that it cannot be used against the defendant in future civil litigation, but in many cases there is no real chance of that happening. I believe that judges should generally discourage no contest pleas and, where possible, insist on an admission of guilt. This is because personal admissions of wrongdoing by defendants at guilty pleas are important to justice.

30 For a recent example, in describing the death of a suspect in six murders as police closed in on him, the Maricopa County Sheriff in Arizona stated: "Today is not a success story, but it's a story that has closure." Anne Ryman \& Uriel J. Garcia, Six People Killed by Scottsdale Murder Suspect, Police Say, azcentral, June 4, 2018, found at https://www.azcentral.com/story/news/local/scottsdale-breaking/2018/06/04/ scottsdale-police-closing-murder-suspect/668075002/. On closure for homicide survivors provided by victim impact statements, see Susan A. Bandes, Victims, "Closure" and the Sociology of Emotion, 72 Law \& Contemp. Prob. 1 (2009).

31 See Joseph Serna, Richard Winton, Sarah Parvini, Melanie Mason \& John Myers, Suspected Golden State Killer, a Former Police Officer, Arrested on "Needle in the Haystack” DNA Evidence, Los Angeles Times, April 25, 2018.

32 I take this phrase from a speech I heard by Greg Boyle, the Jesuit priest who has devoted much of his life to helping gang involved youth through his organization, Homeboy Industries. Fr. Boyle used the refrain, "they belong to us" to refer to youth on the margin, including those in gangs.

33 California Briefing, Los Angeles Times, Aug. 27, 2015 at B5.

34 Id. 


\section{REDEEMING THE RESPONSIBLE}

Tracy Takahashi ... Tracy Takahashi. His name is grooved in my mind deep-so deep I cannot run from it. I will always be connected to him ... Tracy Takahashi. He will be with me until I die.

John Paul Madrona, a California prisoner, speaking of the man he murdered ${ }^{1}$

We are all caught in an inescapable network of mutuality ... And whatever affects one directly, affects all indirectly. For some strange reason, I can never be who I ought to be unless you are who you ought to be.

Martin Luther King Jr. ${ }^{2}$

To the notion that we should worry about the well-being of the incarcerated, I hear a distinctly American voice rise in protest. Why should I care? Seriously, why should I care? You're talking about someone who has taken a life or lives, either in body or spirit. This person has been convicted - found morally and legally responsible - and been punished accordingly. Why should I care about him, or her, now? Of all the people in the world to care about, why should I care about a convicted violent offender? What could possibly be in it for me or for anyone I care about?

In this chapter I try to answer this voice. While there are self-interested reasons for the law-abiding public to care about offender redemption, such as making optimal use of public resources, my concern remains with justice. We have a responsibility to those we lock up in the name of justice. As Dr. King maintained, we are mutually and inextricably connected. This makes assisting the redemption of the convicted an important part of our own justice efforts.

We send them far away, for as long as we can. Those convicted of violent offenses are generally taken far from their home communities to live behind prison walls and 
gates and doors. From there they may be further exiled to prisons within prisons, units of solitary confinement that go by acronyms like the SHU or THU. Some who have a "for life" sentence, a "with an L" in prison language, will die in prison. Most sent to prison will eventually be released, however.

This chapter addresses questions about offender return to free society. Is real change possible for serious offenders? What does it take? What does it look like? If an offender has changed, will we, the law-abiding, permit his return to free society? Or will we always see the person as defined by his criminal record? If we do agree to release, will we do so only on condition of permanent suspicion?

\section{From Reformation to Redemption}

Not so long ago, offender reformation, also known as rehabilitation, was a central goal of American criminal justice. (For my preference for the word reformation here, see Chapter 6.) The correctional system sought the offender's personal correction. Whether the law's sanction took the form of a probationary term, commitment to a juvenile facility, jail, prison or even confinement in a mental health facility, the goal was to alter the individual's behavior to prepare for a safe return to society. Incarceration was for offender reformation.

In the late 20th century, the policy tide turned swiftly and strongly against reformation in American criminal justice. This story has already been told before, particularly in Chapters 5 and 6 . Here it is sufficient to say that in the late 20th century with rising crime rates, with a new preference for retribution instead of deterrence in penal philosophy, and serious doubts about the effectiveness of rehabilitation programs, incarceration became focused on punishment. More recently, with major declines in rates of criminal violence and a new appreciation of the costs of mass incarceration both in dollars spent and cuts to other public services, there has been renewed interest in offender reformation. Whether the public will support serious new reformation efforts, especially if new spending is required is unclear, however.

In any event, offender reformation should not be the end of the justice story. The ultimate aim should be offender redemption. Reformation describes a personal change in the offender. Redemption represents society's decision to welcome the changed person back into free society.

Redemption takes two (at least). For example, the purchaser of a municipal bond, if he holds it to maturity may claim the face value of the bond from its issuer, plus interest. In this transaction, the bond is redeemed. To use a more street (though not Wall Street) example, a musician who borrowed money from a pawnbroker, leaving as security a violin or saxophone, may redeem the instrument 
on payment of the amount due. If payment is made within the contracted time, the pawnbroker must return the instrument to its owner; it is redeemed.

For a prisoner to be redeemed, he must show that he is reformed and thus ready for social return. He must show that he has changed. Then society should permit his or her return.

Finally, drawing on its use in Judaism and Christianity, redemption connotes the restoration of an outcast to belonging. ${ }^{3}$ We have seen how violence often stems from not-belonging, how it may be motivated by a hope to belong, or conversely, anger at exclusion. This makes an invitation to belonging one of our most powerful weapons against violence. Redemption of offenders occurs when offender and society both commit to the prisoner's return to membership - to belonging - in free society.

In Western culture, we have many examples of individuals who have been redeemed from past failure, disgrace or wrongdoing. We find these in religion and politics, and above all in popular entertainment, where it seems like a space in the bright lights is always reserved for a Name making a public comeback. Whether past sins might involve drugs or alcohol, sexual misbehavior or domestic violence, racist, sexist or homophobic comments or abject failure, ritual exercises of contrition are all that is needed to bring the person back into the fold. Often with a big public hug.

Those convicted of crimes of violence, however, remain largely beyond redemption in the public's eye, assuming of course that they were never famous. (The famous have their own rules.) The ordinary violent offender is written off. He is permanently dangerous. Not salvageable.

Yet most will be released from prison, eventually. And some clearly do change in fundamental ways.

\section{Offender Change Inside}

Western culture provides very few acceptable ways of saying, "I did some bad things. What can I say? I was a prick. But I'm not a prick anymore." A story like that will not fly in a society that believes, crudely, "once a prick, always a prick.",

Offenders who seek redemption must take responsibility for their past wrongs. Society will demand this to assure future good conduct and to defend basic moral and social principles. Yet taking personal responsibility cannot mean permanent condemnation, or redemption will be impossible. There must be a place in the offender's life story for change. 
We begin our consideration of offender redemption with the changes that offenders must make. Then we consider how society responds.

Just as victims of violence find that healing is a journey, and a long one, so those imprisoned for crimes of violence must travel a long road to redemption. As with victim healing, the journey lasts as long as life does. Still there are landmarks that mark one's progress.

The following account of one man's journey may serve as an introduction to the process. His name is Mario.

I first went to jail when I was 10 years old. My friend and I were playing with a 12 gauge shotgun and killed my friend, José, by accident. It took half of his shoulder off and half of his neck. There was blood everywhere. [Eventually, $t$ ] he police figured it out ... They know it was an accident so they decided to let me go home....

I didn't know it then but that's when I started to repress my feelings. I never learned how to express when I was hurting. I remember at the funeral [for José] I watched everybody crying, yet I never did. I thought if I cried I would be looked at as weak. So I never did. I never showed emotions or even cared whom I'd hurt.

I was in and out of jail until the age of 17 when I committed my murder. It all happened so fast - all I knew was what happened was something I couldn't take back.

It took a lot of soul searching in order to deal with all the pain I caused. I never cared that my victim had a mother or father or family or friends who really cared about him the way I feel about my loved ones.

You know growing up in prison isn't something I'd wish on anybody. These places are full of people with hate in their hearts and they all think like you-you know, like no one can touch me. I know how it feels to think you are so tough that you don't fear anybody. I want to tell you prison is full of people like that. I know. I thought that for a lot of years. ...

I remember always making excuses for everything. Nothing was ever my fault. I always blamed everybody else for my problems. Until one day I finally started to accept responsibility for myself. I took responsibility for my choices, for the decision I made in my life. ...

When I started to go back into my life and saw what got me where I am today, it also brought a lot of pain because I started to see and feel the pain I caused. My victim had a name-Carlos. He also had a beautiful family who loved him. I caused them a lifetime of pain. I murdered their son. I killed 
someone they love and miss very much. I remember when I started to feel the pain. I couldn't stop the tears because I started to feel all my pain.

I know the words I'm sorry don't even come close to giving my victim's family any kind of comfort. I feel so ashamed for the pain I caused. I know now there is nothing I can say or do to help heal the family. And I have to live with the decision for the rest of my life. Today I continue to look at myself and continue to better myself. It took the life of a human being in order for me to see and feel the pain I caused and I will regret that decision for the rest of my life. No one has the right to take someone else's life. If you want to see what I mean ask your mother how she would feel if you had been the one who died. ${ }^{5}$

Mario's story is a familiar one: a boy's early experience of trauma leads to emotional repression. In adolescence, he determines to make his way in a tough world by being tough. He lives highly attuned to threat, ready always to respond with force. He does what he feels he must, giving little thought to the consequences for others. Later in life he begins to think and feel relationally. He sees the link between his own actions and the suffering of others. He commits to personal change.

This is a story of connecting by one disconnected. Mario tells of connecting with emotions from which he has been disconnected for years. He connects with people beyond his immediate circle of relations. He sees the link between his own actions and those he hurt, not only the woman he killed but her loved ones and friends. Mario takes responsibility for his past wrongful actions and responsibility for his past self who did not care about others. He also takes responsibility for who he is today.

Someone like Mario, who has committed serious criminal violence and makes a claim for redemption, presents us with at least three fundamental questions. First, does he get it, what he did? Does he recognize the evil of wrongful violence? Does he show insight into his past life and criminal offense, to use the word that figures prominently in parole board decisions?

Second, is he for real? Are his words sincere? Is he expressing a true change of mind and heart or is he just saying what we want to hear in order to get out?

Third, assuming he shows insight and has changed, are we willing to stop punishing him for what he did? Are we willing to change our relationship with him?

\section{Personal Transformation: Beginning with the Pain}

For me a big surprise of jail ministry was the tears. I did not expect to see men crying in jail. Now I should be clear, this does not happen all the time. On the ins, 
meaning while in jail or prison, toughness is expected. Flat facial expressions; eyes hard or distant, these are pretty standard. Occasional anger, sure. Tears? Crying? Not for men locked up. Crying is for girls. For a man, tears show weakness, almost unthinkable in a place where weakness can provoke verbal, economic and physical attack. And so guys inside don their face masks every morning along with their jail issued clothes and wear them faithfully. Until something happens and the mask slips.

In ministry, the tears often come in a private conversation or prayer, when something painful is confided. Or it might be in a small group, where sufficient trust has been built that long suppressed feelings and experiences can surface. They may come in a discussion of mercy or guilt or shame or forgiveness. Mostly they come when thoughts turn to loved ones on the outside who have been hurt or who will be hurt by the man's deeds and incarceration. Thoughts of parents or grandparents, children, brothers or sisters, cousins, who suffer because of what he has done or not done or because of his absence, this is the pain that lies closest to the surface and is most likely to find expression in tears. Related to this pain, but rarely given voice, is the fear of losing connection with loved ones. Every prisoner fears abandonment, being left behind, having no place of true belonging in the free world.

Guys in prison are tough in many ways, they have to be, but that is not their whole or even essential nature. As with most of us, what they present to the world is not all that they are. The connections that the men feel to those on the outside, whether to a mother or grandmother, a step father, father or an uncle, a sister, girlfriend or wife or even former wife or girlfriend, provide a critical anchor in their relational world. These individuals comprise their circle of regard-the people they care about. Redemption requires expanding this circle of regard to include even strangers.

It is a given in corrections that inmates who stay connected with friends and family are the most likely to succeed when released. Compared to other prisoners, these men and women have the strongest sense that they do-or can-belong.

There are plenty of prisoners, however, who get no visits or calls or letters, who seem to have been abandoned by those they once knew on the outside. There are also many prisoners who remain emotionally shut down, who continue to suppress feelings and memories. For these the path to redemption is more difficult. Not impossible, but longer and more difficult.

At the end of Chapter 5, I referred to a program that I was part of that combined spiritual discussions and therapy exercises for 16- and 17-year-old boys who were incarcerated at juvenile hall in Los Angeles County. All had been charged as adults; many faced possible life sentences. I did the program with my wife who is a 
Licensed Clinical Social Worker. She led them through a number of imaginative, writing, drawing and physical exercises designed to help them gain better understanding and control of their feelings. I remember that during one session, while the others in the group did the exercises, one young man sat quite still, never speaking or moving. Then, after a discussion of emotions, he spoke up. Looking directly at me he asked, clearly and calmly, "What if you don't do emotions?"

I do not know whether his not-doing-emotions was a conscious decision on his part, the result his upbringing, a symptom of a psychological condition or might be explained in some other way. ${ }^{6}$ He did not say. The question has stuck with me because of its stark challenge. How does someone work towards redemption without "doing" emotions? One answer (I suspect there are many) is a journey into the past.

\section{Connecting with the Painful Past}

Criminal violence emerges from social experience, most commonly brutal social experience visited upon vulnerable children, who suffer for our neglect of their welfare and return in vengeful wrath to plague us.

Richard Rhodes ${ }^{7}$

I was a good provider. I worked hard, made good money. Took care of my family. So in that respect I was really responsible. But when it came to emotional stuff, when it came to interacting with my wife, in a sharing from something deep inside me, I never made it to that point. I just kept everything to myself. Smashed everything down, for all my life, whatever it was, ever since I was a kid. And that's a big reason I ended up shooting Charlie. That's where it all exploded: on Charlie.

Former lifer on the murder that he committed ${ }^{8}$

Those who commit serious violence are almost always survivors of serious trauma. They have experienced some of the worst that life can offer a young person in the way of neglect, abuse, family chaos and witnessing violence. All of which they have survived. To survive is not the same as to live, however. In fact, strategies used to survive-disassociation is a classic example - may cause major problems in living. Suppressing emotion, denying the past, developing hypersensitivity to threat, these are other survival skills that may interfere significantly with life in community.

Most who commit serious violence are survivors of serious trauma in another way as well. They have grown up with traumatized adults. When parents or caregivers have what is called unresolved trauma, usually meaning histories of violence that they have not fully acknowledged or worked through, they cannot provide 
the calm and secure models of behavior and relations that children need. Instead of demonstrating consistent concern, the caregiver may become unpredictably cold and distant, or terrifyingly angry. The relational bonds needed for a secure life are never formed. ${ }^{9}$

We know that the experience of serious trauma may leave a person with a fractured, volatile, unpredictable self. In important ways, the person may not understand him- or herself, may not understand why he or she thinks or feels as he or she does. The individual may not comprehend or even recognize that situations that appear to him as life-threatening, would seem only mildly challenging to others. The person may also be unable to deal with the ordinary challenges of intimate relationships, suddenly resorting to violence for reasons that not even he understands.

I hurt someone I really cared for, that's what put me here [in prison]. I can't forgive myself, let alone expect anyone else to forgive me. I can't understand why my life keeps going in a direction contrary to my wishes. I try and I pray, but my ego takes control for just five minutes, and I do something I regret for the rest of my life. ${ }^{10}$

Of course, being a criminal by choice and inclination, I am very fragmented in my personality and can do two completely different things within the space of a few minutes, and be sincere in both of them $100 \%$. This is why most people regard people like me as "phonies" when in reality we can be quite sincere but totally inconsistent. ${ }^{11}$

Someone who has been traumatized has strong reasons not to revisit traumatic events. Why go back to what caused and still may cause so much pain? Why not focus on present problems and future possibilities? There is a simple answer: because a painful past can hold the present and future hostage. The change desired for today may be impossible without a change of understanding and attitude toward what occurred in the past, even the distant past.

Work on a painful past requires recognizing what happened, appreciating its significance, and accepting, even embracing, the past self who suffered. ${ }^{12}$

Just recognizing what happened can prove challenging. Trauma can cause dissociation, leaving blank spaces in the memory. With the help of a skilled therapist, these can be filled in to some extent. Without this work, though, the memory remains lodged in the body, where it can affect future life in surprising and usually disturbing ways. Unfortunately, effective trauma therapy is rarely available in jails or prisons, where mental health professionals are primarily tasked with psychological assessment and medication management. 
Next, the significance of past trauma must be appreciated. The male tendency to shrug it off as something long ago survived and surmounted is powerful. Yeah, my dad used to beat us up pretty bad along with my mom, and then when she finally left him we ended up in a lot of really nasty places, saw some bad shit, whatever. But that's not me now. Women may complain about past injury, but men need to get over it. Men retaliate for injury or become harder as a result. Men deny or deflect pain. A man is not a victim.

Which brings us to the challenge of acceptance. Can the individual fully accept past losses and hurts? How does today's man view the boy who was so badly hurt or scared, who felt so lost and hopeless? For offenders, the relationship between past and present is often characterized by blame and harsh judgment. Hey kid, you should never have let that happen. Or, you can't let that kind of thing get to you. You need to be tough. Or even worse: you disgust me. You should feel ashamed. The present self may seek to put maximum distance between present and past iterations. I don't want to hear you, feel you, see you. Get lost.

These attitudes block change. For the traumatized, change goes through the pain, not around it. The similarity here to victim acceptance of loss should be clear, and makes sense, because both involve healing from past hurt.

Acceptance of a past self requires connecting past actions or experiences with the person today. The word ownership, common in recovery and therapeutic circles, is useful here. Can the individual own some of the most painful experiences of his life? Can the person say about past bad experiences: that's part of me, as opposed to treating them as events that can be denied, minimized or pushed away?

None of this would be so hard but for the dark force of shame. Shame is feeling worthlessness in the eyes of others and oneself. In the context of violence, feeling shame can be paradoxical, as innocent victims often feel shame from their own victimization. The man feels ashamed for what happened to him or for what he saw when he was a boy. Shame is especially strong in response to sexual victimization. Such victimization is common in the backgrounds of male offenders. Shame can be inspired by experiences of youthful terror, or by failures to protect mothers, sisters, brothers or cousins from violence, no matter how impossible that might have been under the circumstances. We know that shame from victimization can be a powerful instigator of later violence. ${ }^{13}$

Acceptance of past pain means realizing that the young victim or witness should not be blamed, and never had any cause for shame. It means realizing that the boy had every reason to be scared. Ideally, the present self treats the past self with concern. It's a matter of moral regard. Can the man of today see the boy or young man as he was then, and care about his good? 


\section{Taking Responsibility for Wrongdoing}

Now we come to what the law-abiding most want from the offender: acceptance of responsibility.

Edel Gonzalez was convicted of first-degree murder and sentenced to life without chance of parole for his participation in an attempted robbery and murder. He and fellow gang members decided to carjack a car. They needed transportation to retaliate against a rival gang. Gonzalez stepped in front of a car driven by Janet Bicknell, a teacher's aide. His action forced her to stop; he then tried to open the driver's side door, but it was locked. At this point a fellow gang member fatally shot Bicknell in the head. Seeing what they had done, Gonzalez and his gang compatriots fled, without the car. Gonzalez was 16 at the time.

What follows is from the statement that Gonzalez gave to the parole board. (He became eligible for parole because of new legislation in California that permits the resentencing of those sentenced to LWOP for crimes committed as a juvenile.)

I'm here before you ashamed, embarrassed of my actions and the senseless, horrendous crime that took the life of Ms. Janet Bicknell and that I have hurt so many lives. Mr. John - her brother, her only brother, Mr. Carl David Forni, her life partner, family, friends, her students to name a few, for the pain, suffering, stress, headaches, sense of loss I put in their lives ... and their mind, for their tears that I caused, I apologize. Because in the midst of a crime, I behaved as a coward for not speaking up and saying no, let's not do this or stop, don't shoot. There are points in the life crime where I should have made the decision to leave and not be part of this horrible tragedy but I didn't because I was fearful and a coward. I lived with the knowledge that my insecurities, my needs to approve and fit in, my pride, my selfishness, the fear to be my own man led me to commit the senseless crime. I ripped Ms. Janet Bicknell from her life, her family, her loved ones. I hurt them immensely. I broke their hearts. I can only imagine the initial fear that Ms. Janet Bicknell must have felt when ... I stepped in front of her car to slow it down. That fear quickly turned into terror. I attempted to open her door as she sat there in complete shock and disbelief. Within seconds, she saw a gun pointed directly at her. Her whole life flashed before her ... ${ }^{14}$

Here Gonzalez expresses his understanding of the evil of the crime in which he participated. He details its relational consequences well beyond the death of the victim, and expresses remorse for his participation. He identifies specifically the wrong choices that he made and did not make. 
Gonzalez then passes judgment on his own character at the time of the crime: "I am forever reminded of the type of person I was, the horrible crime of taking Ms. Bicknell's life." And he tells the parole board of his commitment to change. "I know now as an adult I do not ever want to become that person again. I want to cherish and appreciate and love life. I want to help young kids to understand that all this false family of this gang lifestyle out there in society and in prison is nothing but a lie." 15

Gonzalez was found suitable for parole and, at the age of 39, having been incarcerated since he was 16 , he was released from prison.

\section{The Identity Dilemma: Reconciling Past and Present}

We would like all violent offenders to be as forthright as Edel Gonzalez, taking full responsibility for past wrongs and character flaws. We would like all offenders to condemn the evil acts they did and commit to fundamental moral change in the present. Few reach Gonzalez's level of moral insight, candor and judgment, however. Why? Why is such a full-blooded statement of personal responsibility so difficult even for offenders who know they have done wrong? Call it the dilemma of identity. How can you condemn past acts without condemning the person who committed them?

Consider this. How many people do you know who will condemn-morallyimportant actions that they have taken in the past? I do not mean admitting making mistakes, conceding general immaturity or bad influences. I do not mean admitting to self-destructive, insensitive or stupid behavior. I mean, forthrightly admitting to serious moral wrongs. How many will detail how they have lied, cheated, or committed crimes, with names and dates and specifics? That's rare. The social costs are too high. If we admit that, we worry that no one will ever like or trust us again. But it's not just the social costs that hold us back. We cannot admit to ourselves that we went so far wrong. We cannot admit to being such a person then, because if we did, we could not live with ourselves now.

For offenders, redemption requires a life narrative that embraces both past wrongs and present possibilities. The offender must find a way to take responsibility for past violent acts, but not be defined by them.

Veterans of combat returning to civilian life must do much the same. Karl Marlantes who has written searchingly about killing in combat, asks: "So am I a killer?" He answers: "No, but part of me is." ${ }^{, 16}$ Most of us distinguish in our own lives between acts that seem to be more products of particular situations than reflections of our own essential character. We do the same for people we like and respect. We reject this approach for anyone convicted of a violent offense, though. 
For example, consider these words from someone who committed a sex offense: "I did rape ... that night, that time, I think I did. But I'm not a rapist."17 Many will hear rationalization, minimization and denial in these words. We would certainly need to hear much more to be convinced that the speaker takes full responsibility for past actions. But do we expect this man to call himself a rapist? What is left after that? ${ }^{18}$

Acknowledging the viciousness of past selves can preclude contemporary change. It can even excuse an offender from making the effort to change. I'm just bad. That's how it is.

I think part of the trouble is that we cons become oppressed by our crimes. All of us spend too much time looking back. We see how stupid and useless our lives have been, and then it is hard to believe that we might be capable of the tremendous task of the divine journey. We find it hard to believe that God is really within us. ${ }^{19}$

Finally, a word about personal expressions of change. Offender redemption requires a shift in understanding, attitude and commitment. Statements of confession, remorse and responsibility may indicate these shifts. But actions count more than words. Which means we should be skeptical about offenders who say the right things but whose record of change is mixed. We should trust more those who struggle to find the right words, but whose lives show change.

\section{Creating Opportunities for Change Inside}

No one can be made to change. No one can be made to feel responsible. No one can make another person change their behavior when they have a choice about how to act. This is one of the hardest lessons of life, that there are basic limits on anyone's ability to affect another's choices. Parents can strongly influence their children's behavior, but moms and dads know that even the youngest have wills of their own. In adult relationships, influence is even more constrained. A wife may influence her husband, and a husband his wife, but only sometimes and usually in small ways. You have to stop drinking so much, eating so much, working so much. How often do these words change the problem behavior? You need to get some help because you have a problem. Will the person then get professional help? If threats and cajoling from those closest to the individual mostly fail to produce the desired change, what are the chances that the state's mostly coercive efforts will alter the lives of prisoners? Would you change how you think and feel, or how you live your life because the state said that you should? Would you change if the state said that you must? 
The simple truth is that the state cannot force prisoner rehabilitation. If a prisoner does not wish to change, the best rehabilitative programs will not work.

This does not relieve us of obligations to assist change, however. The obligation of moral regard (remember the idea that we should punish with moral regard) says that we must give the incarcerated an opportunity to change. For their redemption, we must do our part.

Again note the similarity to victim healing. Whether and when and how victims change their response to the crime depends on the victim. He or she must decide. Still there is much we can do to help victims heal. The same is true for those who have committed violent crimes.

\section{Growth through Story Telling}

Individual growth through story telling sounds more than a little ridiculous as a plan for violent offenders. But it can work. We have seen the need for offenders to connect present realities to past experience. That's the stuff of storytelling. Hearing the stories of other offenders can be revelatory this way. Another man's painful story may help the listener understand that he is not alone in his experience, and that what he suffered is not evidence of weakness or cause for shame.

A number of researchers in psychology and criminology in recent years have undertaken narrative studies that analyze the accounts that individuals give of their own lives. This is based on the idea that our identities depend on the stories we tell about ourselves. One of the great challenges of offender redemption is the construction of a coherent personal narrative that connects a painful past to a promising present. Here are some common ways that is done.

\section{Conversion Stories: the Role of Religion in Personal Change}

Many offenders who change their lives give all the credit to God. Prisoners frequently say that faith in their Creator (or Jesus Christ, or Allah, or other names for the divine or a higher power) has made all the difference in how they see themselves. God plays a vital role in their narratives of personal transformation. The following are accounts from inmates in California state prisons.

I remember when I left my gang. It was only then that I could get serious with God and open my heart to him. I didn't want to do it before because it was like I was living two lives and I was being a fraud. So I waited until I was ready to break all ties. By this time I was truly hungry for God because I knew 
if anyone could clean up the mess I was within, it was through God's miraculous power that I stood any chance.

The day I opened up to God, really prayed to him, I remember I felt this strong peace afterwards, and I knew that this was the beginning of the healing process. That day I felt truly loved and it also brought me a hope that I [had] lost. ... There's a lot of things in life that I regret doing, but I'm very grateful to the mercy and grace of God that I'm given a second chance to make things right by living for God, my family and those in need. ${ }^{20}$

I have been a sinner for a very long time. I have been damaged. But Jesus has healed my suffering. He has made me want to be a better person. I will show him that I was worth it by helping others and being a man he will be proud of. ${ }^{21}$

I remember my last two years or so as an active gang member sitting in the SHU. ${ }^{22}$ The disillusionment with "The game" really started to sink in and I felt angry that my pride would not allow me to walk away from a life that I no longer believed in. ... I felt unworthy of [my family] and unworthy of God. ... But one day God gave me the strength to walk away from that life. He showed me that I wasn't worthless. That I am somebody. That through His grace, I am worthy. ${ }^{23}$

Many who hear words like these may say: wonderful if true, but how are we to tell? The American commitment to separating church and state in the public realm means there must be a secular basis for evaluating offender redemption. While positive changes that result from religious experience are welcome (because positive changes are always welcome) judges, parole board members and other public officials should be reluctant to examine their faith foundations. How can anyone tell if another's faith is sincere, and whether it will endure? Surely we do not want public officials assessing the validity and sincerity of any person's faith. Down that path lies all manner of ugly sectarian and intra-sectarian disputes.

Following the secular approach I have taken so far, I will limit myself here to addressing widespread doubts about the reality of jailhouse conversions. Why should we believe the inmate who says that he found God in jail when this profession may be used to win release or lessen punishment? A recognition of the inmate's self-interest here surely warrants skepticism on our part. And, even if the inmate's faith is sincere and true now, who can say whether it will hold when the person faces the temptations and stresses of life in free society? These are legitimate questions, often debated by inmates themselves. And yet there are reasons to expect that religious conversions in prison may be for real. 
The experience of serious illness or the death of loved ones, often brings questions of religious faith to the fore. (Even as, for some, these experiences have the opposite effect.) Personal crisis can inspire faith. As noted before, incarceration presents an existential threat to the prisoner. So much is taken: freedom, relationships, work, community. Prisoners lose most of what gives life meaning. The question of how to go on, how to find meaning in this place of awful routine and extreme limits, of hard rules both written and unwritten, and little hope, is profoundly challenging. Religion provides an answer. Religious faith can supply hope, meaning and purpose. For those who feel alone inside, experiencing the presence of a loving God can be transformative. Few people need God more than prisoners do.

Given this we should not be surprised, nor should we treat with special skepticism, claims of religious conversion in jail or prison. As always, what matters most is action, not words.

\section{Recovery and Other Narratives of Change}

Beginning in the 20th century, another kind of conversion account has gained power in America-the recovery narrative of addicts. Twelve-step programs, originally developed for alcoholism, have been adapted to drug addiction and addictions to gambling, eating, and sex. The most important such programs for offenders are Alcoholics Anonymous and Narcotics Anonymous. Each provides a communal structure for articulating what a person has done and experienced, and a framework for changing a life course. Twelve step meetings feature personal accounts of the individual's substance abuse past and present, and his or her experience of (or struggles with) sobriety. Narratives of a personal fall due to drugs or alcohol, a recognition of powerlessness to change without help, a commitment to community, acceptance of responsibility, recovery and giving back are essential features. ${ }^{24}$

There are other programs, less structured in terms of the narratives encouraged, that emphasize self-exploration. Of this type, one of the most impressive I know of is a California-based program called Victim Offender Education Group (VOEG), in which a small group of prisoners meet weekly for 18 months with facilitators to work through past experiences and take present responsibility. Based on a carefully developed and tested curriculum that draws on therapy practices, the program challenges prisoners to come to terms with their own past victimization and the harms they have done to others. ${ }^{25}$

InsideOut is another California-based program that helps youth incarcerated in juvenile detention halls find their voices, and a greater sense of identity and 
agency. ${ }^{26}$ Writers and teachers lead small groups of teenagers in writing exercises and discussions. Many of them, for the first time, find power and insight in telling their own stories and sharing their stories with peers.

\section{Finding Purpose: Education and Vocational Training}

Among the many things incarceration takes from the prisoner is purpose. For many locked up there is nothing to do inside except time. Effective rehabilitative programs can change this by giving offenders a new purpose through education or work training.

Most incarceral facilities have some form of General Education Degree (GED) program for those who do not have a high school diploma. Given the educational deficits of many prisoners, this is vital. Many facilities also offer two-year Associate of Arts (A.A.) degrees, equivalent to that provided by two-year community colleges. Relatively few jails or prisons offer college degree programs except through correspondence courses, which are useful, but no substitute for live, in-person teaching. The evidence is clear, though, that in-prison education helps reduce recidivism. ${ }^{27}$

In the past, prisons offered a wide range of vocational training. Over the last twenty or more years many such programs have been cut, but some remain. Depending on the institution (generally the lower the security level, the more programs are available), there may be training in welding, plumbing, carpentry, in the electrical trades, heating, ventilation and air conditioning, in barbering, food services and medical assistance, in the use of computers and automotive repair. These give inmates skills they may use on the outside. Equally important is growth in self-confidence that comes from doing difficult, productive work. A good example in California is fire camp, in which youthful offenders are trained in fighting wildfires and then go onto the front lines to fight fires. Unfortunately, as with educational offerings, vocational training opportunities for inmates are often limited by budget cuts, the availability of teachers, security restrictions and prisoner transfers between institutions. ${ }^{28}$

The best inmate programs are empowering. They give prisoners the opportunity to do and to become. Animal training programs are a great example. Another that has impressed me in California prisons is Prison of Peace. This program trains inmates to become conflict resolution mediators. ${ }^{29}$ Participants learn the basics of restorative justice and mediation, in the process learning a great deal about their own emotional lives and communication skills. Those who complete the program are certified as mediators and can help resolve inmate conflicts within the institution. The most committed can become trainers of other inmates so that the program becomes self-sustaining in the facility. It seems to be a great fit between individual and institutional needs. ${ }^{30}$ 


\section{Reality Check, Part One: Offenders Who Do Not Change, or Haven't Yet}

A hard truth: some offenders don't change. They may be so broken from prior traumas that, with the limited help available in the facility, they cannot manage the transformation that redemption demands. Or, the person may set himself against redemptive change. He may consider violence part of his moral code. For example, here is an inmate justifying the murder of another inmate who had killed the speaker's crime partner.

I don't have any regrets at trying to kill him and even if he died and I received a life sentence, I still would not regret it ... I respected my [crime] partner and [our] friendship to the extent that I felt what I did had to be done. It's oldfashioned when it comes to values and morals and living by the convict code, but that's me, and I've never claimed to be anyone but. ${ }^{31}$

Some inmates despair of change. This is who I am; it's too late to change. Or they despair that anyone will care if they do change. What's the point if everyone sees me as a monster? And finally there are those who do not see anything wrong with predation. As serial killer Ted Bundy explained to an interviewer: "I feel sorry for those who feel guilt., 32

With offenders who have not changed, the temptation is to say they never will. And perhaps that's right. As long as human life lasts, however, change is possible. Unlikely and improbable do not equal impossible.

\section{Reality Check, Part Two: The Culture of Modern Corrections}

Early in my academic career I wrote an article about the history of penal reform in America in which I argued that from the creation of the penitentiary in the early 18 th century to the late 20th century development of determinate sentencing, major change in punishment methods or policy has occurred when liberals and conservatives joined forces. In each instance, liberal reformers proposed what they believed were more enlightened ways of responding to crime and conservatives came on board when they decided that the proposed change promised a more effective way of punishing crime and keeping social order. ${ }^{33}$

What change actually resulted, what was put into action, did not just depend on this (usually fleeting) liberal-conservative coalition, however. There was a third group that in the long run had the final say on punishment in each epoch: those who ran the newly created or reformed penal institutions. Penal institutions, like all 
institutions, seek to protect their own powers and position and these interests may not align with the larger ideals that public officials proclaim. Institutions can develop their own cultures impervious to outside direction.

I remember the first time I visited a prison in California. I was immediately struck by the dress and demeanor of the guards - the correctional officers-as they are called. (This nomenclature is preferred by officers to emphasize their status as peace officers. ${ }^{34}$ ) In their green jumpsuits, dark belts and holsters at both waist and thigh, black boots, and for outside wear, floppy hats and opaque sunglasses, they looked as if they were ready to deploy to Iraq or Afghanistan. It might be pepper spray in their holsters instead of a gun, but the presentation was similar enough to cause initial confusion. These COs carried themselves with a swagger, both male and female. They were the ones in charge of this level four (highest level of security) institution-and they were in charge. Before our religious volunteer group set off to go into the prison, one male CO loudly warned us to stay alert to the hazards that might lie ahead.

There is a direct connection between the perceived dangerousness of inmates and the perceived value - to COs - of corrections work. The more dangerous and irredeemable the inmates, the more valuable — and difficult — the work of keeping them locked up. In this way, correctional officers become professionally invested in seeing inmates according to their offenses, rather than as people capable of change.

Of course inmates can be dangerous. And unpredictable. And clearly the whole enterprise of keeping other human beings, most of them male and young, in captivity for years is grinding, hazardous work. It requires constant vigilance, not just to prevent violence and escape, but to maintain the psychological authority that outnumbered guards must maintain. In this work, far better to be too suspicious than not suspicious enough.

Nor do I think that corrections officers should be expected to do much corrections work. The requirements for maintaining security and encouraging rehabilitation are too different to do both well. It should be enough for corrections officers to treat inmates with basic respect. Inmates complain most and most bitterly about being disrespected. Although it is common, disrespect does not further any legitimate penal goals, including security.

\section{Redemption? Parole and Reentry}

Redemption takes two: a redeemed and a redeemer. So far we have looked at what offenders must do to be redeemed; now we look at society's role as redeemer. We look at the decisionmakers who have the power to grant or to deny social redemption. 
There is no greater test of our willingness to give up good guys v. bad guys thinking than the question of whether we are willing to consider-to consider-the redemption of violent offenders. Are we willing to entertain the idea that a person might be more than his or her crime, if the crime is serious? Are we willing to consider that a person who did a serious wrong might change enough over time to rejoin free society? Will we acknowledge that a freed offender belongs among us?

I will focus on two sets of redemption issues here: (1) the decision whether to grant parole release to life-term offenders, and (2) the conditions of an offender's reentry to free society.

\section{Parole Decisions: Reconciling Present and Past}

There was a time in California (in the 1960s and early 1970s) when the state's parole authorities had more say over how much time a prisoner served than the sentencing judge in the case. The state had a particularly indeterminate version of what was called indeterminate sentencing. Under this scheme, a judge would sentence an individual to prison, setting a minimum and maximum length of incarceration. The parole board later decided how much time the prisoner actually served. It was not unusual for prisoners to receive sentences like one year to life or three years to life. Many states followed a similar model, although with not as great a penal range.

Indeterminate sentencing was premised on the idea that correctional experts could determine which inmates were ready to return to society and which were not. At least in theory, the length of incarceration depended as much (or more) on the individual offender as on his or her crime of conviction.

In 1976 this changed, as California became one of the first states in the country to enact a determinate sentencing law. Under the new regime, for the great majority of defendants, the judge's sentence determined the length of incarceration, subject only to standard good time credits. ${ }^{35}$ Discretionary parole releases were eliminated except for offenses where the offender was given a life sentence with the possibility of parole. These were primarily murders. Many states took similar actions. Some states went further and abolished discretionary parole entirely, making any life sentence effectively a sentence of life without chance of parole. ${ }^{36}$

In later years, legal and political changes in California made obtaining parole release extremely difficult for inmates who were statutorily eligible. In 1988, voters approved Proposition 89, which modified the California Constitution to give the Governor the power to overturn parole board decisions. Under this new law, the parole board might find a life term offender suitable for parole release and provide a date upon which that inmate might be released, but the Governor had 150 days to 
"take the date" by reversing the parole board decision. Successive governors, both Republican and Democratic, used their review power extensively, making parole releases rare. Prisoners serving to-life sentences in California were more likely to die in prison than to be released. ${ }^{37}$ In recent years, parole releases for California lifers have become more common. A steady decline in the crime rate, a significant change in correctional philosophy by Gov. Jerry Brown and a ruling by the California Supreme Court that parole release cannot be denied based entirely on the facts of the original crime has changed the parole landscape. ${ }^{38}$

Nationwide, controversies about parole release frequently involve a struggle between the relative significance of past and present: the past crime and the present prisoner. Law enforcement representatives normally emphasize the prisoner's past crime, seeing it as the most reliable indicator of individual character. Advocates for offenders argue that parole decisions should depend on contemporary assessment of the person. Individuals do change over time. A person who might have been dangerous as a young man or woman may be a very different person 15 or 20,25 or 30 years later. ${ }^{39}$

\section{Reentry: Something Less Than a Welcome}

Most offenders sent to jail or prison are eventually released from confinement. Release from jail or prison should not be confused with a welcome back to community, however. Families may welcome back the formerly incarcerated-or they may not. American society almost never does. Instead, the near-total exclusion from society that characterizes American incarceration, gives way in many cases to a myriad of hidden restrictions and exclusions that make former offenders a truly suspect class. ${ }^{40}$

The recently released are second-class citizens by law. Most lose their constitutional rights against unreasonable searches and seizures during their time on probation or parole. Where they can live and how far they can travel is usually restricted for years. In many jurisdictions, felons lose the right to vote and to serve on juries. They may be excluded from public benefits, including public housing and food stamps. Their convict status bars them from many occupations, including those for which they may have trained in prison. Even beyond formal prohibitions, finding work can be difficult because many employers will not hire an ex-con, will not even consider hiring an ex-con.

And then there is the treatment of those convicted for sex offenses. Required registration as a sex offender, in some states for life, brings social shame, severe employment limits and residential restrictions. With sex offenders we see better than anywhere the hazards of conflating person with offense. Some sex offenders, particularly those with a history of repeated sexual attacks against strangers, are 
extraordinarily dangerous. They absolutely warrant special law enforcement attention. They are, however, a small percentage of those convicted of sex offenses. This means that, as a measure to protect public safety, the current sex offender classification is too broad, labeling as dangerous persons who do not pose a special risk of future sex offenses. (Statistically, most who commit sex offenses have no prior record of sex offenses.) Such broad categorization also spreads law enforcement resources thin, meaning less ability to monitor those who have the greatest propensity for sexual violence. ${ }^{41}$

\section{Supporting Change after Release}

In personal narratives, speakers often identify specific past events or experiences as the pivot points in their lives. Before that happened (i.e., before I found God, hit bottom, saw my mother in tears, was sent to the SHU, etc.), I was one way; afterwards I was another. Looking closely at the important changes that former offenders make in their lives, however, we see that change is more often a gradual process, with many starts and stops, detours and reversals. Just like for everyone else. Changing your life is rarely a one-time decision. Instead, like the recovering addict's struggle for sobriety, it is a one-day-at-a-time effort that requires the continuing support of others. Change is interactive and continues over many months and years.

Critical to making and sustaining lifestyle change for many former offenders is taking up what have been called generative activities: giving back to family and community. ${ }^{42}$ Those who have spent decades in prison may emerge to find themselves taking on the role of family or community elder. They see a particular obligation to help young people avoid the mistakes that they made. In this way they may find meaning in past pain and wrongs. There are many programs that feature former offenders going to schools, churches, social organizations and also detention halls, jails and prisons, to tell their life story and offer life lessons. Sometimes generative activity takes surprising forms. Recently I went to an event held to support the Francisco Homes in Los Angeles, which offers transitional housing and services for former lifers, where a man recently released from prison told the following story. Late one evening he was bicycling back from work at a restaurant (many recently released depend on bike transportation, lacking a valid driver's license) and saw a young man confronting an older woman at a bus stop. It looked to him like a robbery in progress. So he wheeled up and spoke sharply to the young man, telling him that back in the day this was not something that any standup guy would do. The would-be robber cursed him out, but he left. The former lifer had become crime-stopper. Who would have thought? 


\section{Redemptive Dialogue: Speaking across Party Lines}

Whether it occurs in penal institutions or outside of them, dialogue between the "us" and the "them" of criminal justice can be transformative. Defense and prosecution attorneys sit on different sides at the front of a criminal court; behind them, spectators take different sides as well. The lines of division are clear. In a homicide case, the defendant's family and supporters often sit on one side and the victim's family and supporters on the other. The system mostly prefers it this way. Everyone has a place and an expected role to play. But special things can happen when the lines are crossed.

Although I have seen it happen on a number of occasions, I often wonder how it happens. How can the simple recounting of personal experiences do so much? What is there in the exchange of words and sometimes hugs that can produce such important changes in those who participate?

I believe that dialogues between persons with different experiences of violence provide a direct experience of redemption. In crossing apparently impassible relational divides, participants come to a surprising place of belonging. They learn that they share experiences with persons who might otherwise be considered enemies.

These dialogues reveal the power of personal relations in shaping identity. Dialogue across offender-victim lines can create new relations and new identities.

\section{Offender-Victim Dialogues}

The most powerful form of dialogue is that between offenders and victims. This can happen in a number of different ways. Victims may be brought into prisons or detention halls to tell their stories to offenders who may be imprisoned for similar cases. Individual meetings between an offender and his or her actual victims may also occur, often arranged through a facilitator. ${ }^{43}$

For victims, a dialogue with offenders can help in healing. Even if offenders disappoint in their words and emotions, the interaction usually reveals their basic humanity. This can check the consuming rage or fear that violence can inspire in survivors. For offenders, dialogues help offenders see the real person or persons affected by their actions. In a setting far less charged than the criminal courtroom, they can begin to appreciate the wrong they did.

To illustrate the dynamic of such dialogues I often show my law students a short segment in a recent documentary called The Interrupters, about the nonprofit CeaseFire group's efforts to stop street violence in Chicago's Southside. A young man who participated in the armed robbery of a beauty salon apologizes to the victims of the robbery three years later. Lil Mikey was one of three gang members who 
held up a barbershop and beauty salon more than three years before. He explains on camera that the robbery was "a war thing," committed to get money to buy more guns for the gang. Mikey was 15 at the time. He spent almost three years in prison for the offense.

The scene opens with Mikey, a nervous smile on his face, standing in the middle of a family-run beauty salon. He addresses those affected by the robbery.

I understand that on August 21 me and two other fellows stuck the place up. I know I am deeply, deeply sorry. I know I made a mistake. I was 15 and I was following the crowd but now I'm older, I'm more mature than I was and I want to let you know that I was sorry for what I did on my own behalf ... I know I made a complete 360 almost three years being incarcerated.

Mikey had no legal requirement to meet his victims or personal advantage to gain by his apology. He was motivated by his own conscience. And yet, as delivered, his words do not carry the emotional or moral force that we might expect. The teen's brief speech comes across as rehearsed. His apology and commitment to change are expressed in generic terms. Mikey describes the crime only generally ("we stuck up the place") and attributes his involvement to immaturity, a condition now cured. This is an apology whose depth and authenticity a skeptic might question. And yet Mikey's sincerity seems clear, as is the courage required to make this in-person apology. These prove enough to begin a serious dialogue.

After Mikey finishes, a woman who appears to be one of the owners of the shop, who has been listening to Mikey with her hands over her face, looks up at him and begins to speak. Her face is wet with tears, her voice hoarse with pain. She talks about how her daughter was present at the robbery, along with her "baby," her 10-year-old son. Patting her hand against her chest she says to Mikey:

And you just don't know the impact that you put on my life, holding us with guns, I'm nervous now just even meeting you and I thank God that you have changed your life but you just don't know what that have did to me and my kids. I deal with this every day. Every day of my life! Every day! You came in here and asked for a haircut, you left back out, you came back in and you did this to my kids, and Jeremy, my baby, with the gun up to his head. ... And you told my coworker Rhonda that you were going to kill her cause she was calling the police. My life was in your hands. I didn't know if you were going to kill me. My daughter kept saying, Momma, we gonna die. ... You want to protect your kids and you can't, at that moment. 
She describes how the robbers put seven people in a single bathroom in the back where they waited, not knowing what would happen. And then she speaks about her son Jeremy, who is shown sitting nearby, his face perfectly impassive. "And right now to this day he never talk about that robbery. It's three years gone and he just turned 13 and he never has said nothing. I don't know what's on his mind but I just praying that God don't let him hold that in."

The mother then stands up and approaches Mikey. She says: "But you know what - I'm a better person now-and I hope that you be a better man." She gives him a full hug. "That's all I'm saying." She pulls back, but holds his two hands in hers. "And I hope that you are sincere." With these words and gestures, the room is transformed.

Later when he is alone with the CeaseFire facilitator, Mikey says that it was "hard, real hard" to hear about how the robbery affected the victims. He says, though, that going in he did not recognize any of the people in the room from the robbery itself. Experiences of violence are often asymmetric in this way, with perpetrators remembering much less than victims. A benefit of offender-victim dialogues is that through victim testimony, offenders start to fill in the details of the victim experience and come to a fuller understanding of the harm inflicted.

There are of course limits to what victim-offender dialogues can do. Even in this interaction we might ask how much actually changed. The person who was perhaps in greatest need of healing was Jeremy, who was ten at the time of the violence. He says nothing throughout. His face gives away nothing. He looks locked down, a dangerous sign as his mother notes. This boy represents the next generation of men in the community. Will the cycle of violence stop here, or will he be drawn into it as well? From this encounter we cannot say.

\section{Family Member Dialogues}

In the Preface, I described a dialogue held by a California group called Healing Dialogue and Action (HDA), which brings together family members of homicide victims with family members of offenders serving long sentences for homicide. The group was initially organized to give family members affected by homicide-on both sides - an opportunity for healing dialogue and, if they wished, to have a larger voice in California criminal justice relating to the punishment of juvenile offenders. (The original action part of Healing Dialogue and Action involved reforming California's law regarding sentences of life without chance of parole for juvenile offenders.)

HDA dialogues begin with participants and facilitators sitting in a large circle and stating their own names and what has brought them to the gathering. Participants 
say the names of their loved one who was killed or the loved one who is incarcerated. Participants usually say the number of years since the loved one's murder, or the total years of incarceration to date, and then say something about their own journey.

The stories told are very different in their details but similar in the pain expressed. A mother tells of her only son shot to death in front of the family home by a teen as part of gang initiation; a husband and wife speak of how their son-in-law took the lives of their daughter and granddaughter, and how they have nevertheless forgiven him; a sister talks about losing a younger brother to prison; brothers talking about losing their sister to incarceration, and mothers talk about losing sons to violence, whether via a bullet or a prison cell.

Those assembled then break into small groups, where people speak in greater depth about their experiences. Again it's hard to say exactly how it happens or when, but in the exchange of accounts, the isolation that violence so often creates is eased. Participants recognize each other because they recognize the other's pain. They can see each other in a way that most people do not, because this other person, he or she gets it, somehow. It's like meeting a fellow countryman in a distant country, with whom one would ordinarily have nothing in common, who now promises friendship just because of shared nationality. A closer analogy might be war veterans who meet those who fought on the other side. They discover that by virtue of their combat experiences they share more with each other than they do with many in their native land, even family and friends.

The differences between family members of victims and offenders remain. Losing someone to prison is not the same as losing someone to murder. Death is incomparably different. Most who speak from the offender side are careful to acknowledge this. Even so, these family member dialogues can create new community. All participants have spent years in the land of darkness that violence makes. By sharing their hurts, they create a new, if temporary, place of belonging.

\section{Conclusion}

History shows that human society can function perfectly well when some members are devalued. The economy may be strong, culture may be vibrant and public safety may be generally secured, even as certain ill-favored groups are treated with great disregard. For the haves, this arrangement works well. And even for those who don't have much, the devaluation of a designated group can have major psychic benefits. It feels good to know that no matter how low one sinks, one will always stand above them. Putting people down can actually feel great. 
We can talk all we want about how we can save money with less incarceration, without sacrificing public safety, but basic change in American punishment practices requires meeting the gut level sentiments that support the lock-em-up enthusiasm of modern voters. They are bad and dangerous and should go away forever. Ultimately punishment must be framed as a justice question. We must ask: can the harsh treatment of all these past wrongdoers, for such long periods, be justified? Many see this as a hard question.

In general, there are two kinds of hard decisions. The first kind is where we don't have enough information, or we must reconcile powerful, competing values. In these situations it can be genuinely hard to know what is right. The second kind of hard decision is difficult because, although it's clear what we should do (if we are being honest), actually doing it is hard. It would threaten our most treasured relations, our self-esteem, the feelings of friends or family or peers. We really don't want to do what we should. It would just cost too much. And so it becomes almost unthinkable.

With respect to offender redemption, there are truly hard decisions about whether an individual offender has changed. But there are also many decisions that fall into the second, but-I-really-don't-want-to-do-that category. The offender makes a valid claim for redemption that we do not want to grant by virtue of his past crime. Too many on the outside are still hurt and angry about the past offense to release the offender, regardless of his personal transformation.

Americans take pride that our law does not recognize caste or class or race. Individuals are judged by actions and not type. But this commitment to formal, legal equality can coexist with, and may even encourage, a ruthless ranking of persons by other means. The human need for social hierarchy has found especially powerful expression in modern America in the verdicts of criminal law. Some people are Criminals: they have been found guilty, right? This seems to give us permission to treat them as criminals, always and everywhere. The principle of punishing with moral regard says no, however. Their violation of the criminal law does not make us God.

The most powerful force pulling ex-offenders back to their old offending lifestyle is not friends or family or drugs or money, but the belief that they have no real alternative, that regardless of how things may work for others, they have no chance at a "good" life. No matter what they do, they will always be have-nots, scrapping for remnants left by the haves. If they play by society's rules, they are doomed. If they don't, they may be doomed as well, but at least for a time they can live free.

The best way to break this mindset is to prove it wrong. Those we have sent away for punishment must be given a chance to change. And those who have changed, we must welcome back. Justice requires it. 


\section{Notes}

1 Kurt Streeter, At a Loss for the Right Words, Los Angeles Times, Nov. 21, 2011, at A1.

2 A Christmas Sermon on Peace, 1967, found at www.thekingcenter.org/archive/ document/christmas-sermon.

3 God's freeing of the people of Israel from slavery in Egypt is a central example of redemption in Judaism. Christianity is built around the belief that God, through the life and sacrifice of his son Jesus Christ, redeemed humanity from the wages of sin and death. In both Hebrew and Christian scripture, the concept of divine redemption draws from the ancient practice of slavery. God frees humans by redeeming-paying for the freedom of-persons held in servitude.

4 Shadd Maruna, Making Good: How Ex-Convicts Reform and Rebuild Their Lives (Washington, DC: American Psychological Association, 2000), p. 144.

5 Mario's Testimony, My Victim Had a Name, Jesuit Restorative Justice Initiative (JRJI), July 2015.

6 The mental health term is alexithymia: an inability to identify or express personal emotions.

7 Richard Rhodes, Why They Kill: Discoveries of a Maverick Criminologist (New York: Vintage, 1999), p. 322.

8 Nancy Mullane, Life after Murder: Five Men in Search of Redemption (New York: Public Affairs, 2012), p. 187.

9 See Daniel J. Siegel \& Mary Hartzell, Parenting from the Inside Out: How a Deeper Understanding Can Help You Raise Children Who Thrive (New York: Tarcher, 2003), pp. 129-31.

10 Bo Lozoff, We're All Doing Time: A Guide for Getting Free (Durham, NC: Human Kindness Foundation, 1985) (letter from Arthur, a prisoner in Michigan), p. 188.

11 Id. at 160-1 (letter from Bill, a prisoner in Florida).

12 "To find the path to peace/ You will have to meet your pain/ And speak its name." Desmond Tutu and Mpho Tutu, The Book of Forgetting: The Fourfold Path for Healing Ourselves and Our World (San Francisco: HarperOne, 2014), p. 60.

13 See James Gillian, Shame, Guilt, and Violence, 70 Soc. Res. 1149 (2003); Larry Ray, David Smith \& Liz Wastell, Shame, Rage and Racist Violence, 44 Brit. J. Criminol. 350 (2004); June Price Tangney, Jeff Stuewig \& Logaina Hafez, Shame, Guilt and Remorse: Implications for Offender Populations, 22 J. Forens. Psychiatry Psychol. 706 (2011).

14 In the Matter of the Life Term Parole Consideration Hearing of Edel Gonzalez, October 15, 2015, Transcript at pp. 77-8.

15 In the Matter of the Life Term Parole Consideration Hearing of Edel Gonzalez, October 15, 2015, Transcript at pp. 77-8.

16 Karl Marlantes, What It is Like to Go to War (New York: Grove, 2011), p. 69.

17 Tim, quoted in Lois Presser, Been a Heavy Life: Stories of Violent Men (Champaign, IL: Illinois University Press, 2008), p. 145.

18 I have seen a similar kind of resistance when talking to youth in juvenile hall about their families. Initially I expected them to talk about abuse and neglect because I knew that this was part of most of their backgrounds. Instead, most spoke very positively of 
their families. I realized eventually that this made sense for many reasons. One is: if you are locked up and you condemn those who raised you, then who do you have left on the outside?

19 Lozoff (1985), p. 196 (Jim).

20 Manuel, a prisoner in California, Wisdom from the Cells, April 5, 2015, JRJI.

21 Jesse, Wisdom from the Cells, May 31, 2015, JRJI.

22 Secure Housing Unit: an area of the prison where the inmate is held in a form of solitary confinement, away from other inmates.

23 José, Wisdom from the Cells, November 9, 2014, JRJI.

24 See Alcoholics Anonymous: The Story of How Many Thousands of Men and Women Have Recovered from Alcoholism (4 ${ }^{\text {th }}$ ed. 2001).

25 The program is run by Insight Prison Project. For more, see http://www.insightp risonproject.org/victim-offender-education-group-voeg.html.

26 The program has inspired several books by its teachers. Mark Salzman, True Notebooks (New York: Knopf, 2003); Edward Humes, No Matter How Loud I Shout: A Year in the Life of Juvenile Court (New York: Simon \& Schuster, 1996).

27 See Lois M. Davis, et al., Evaluating the Effectiveness of Correctional Education: A Meta-Analysis of Programs that Provide Education to Incarcerated Adults, RAND, 2013; Legislative Analyst's Office, From Cellblocks to Classrooms: Reforming Inmate Education to Improve Public Safety, Feb. 2008.

28 On the effectiveness of vocational training, see William G. Saylor \& Gerald G. Gaes, Training Inmates Through Industrial Work Participation and Vocational and Apprenticeship Instruction, 1 Corrections Management Quarterly, 32-43 (1997).

$29 \mathrm{http}: / /$ www.prisonofpeace.org/. I am on the board of this organization.

30 Prison of Peace program reports that, to date, its graduates have a zero percent recidivism rate. Id.

31 Lozoff (1985), p. 154 (Lloyd, prisoner in Louisiana).

32 Stephen G. Michaud \& Hugh Aynesworth, Ted Bundy: Conversations with a Killer (New York: Signet, 1989), p. 288. Bundy also said: "I don't feel sorry for anyone who doesn't feel guilty because the guilt doesn't solve anything, really. It hurts you. You don't need guilt to do the right thing. ... You don't need to feel badly. You don't need to regret."

33 Samuel H. Pillsbury, Understanding Penal Reform: The Dynamic of Change, $80 \mathrm{~J}$. Crim. L. \& Criminol. 726 (1989).

34 For an illuminating account of the role change in California from correctional officers who had rehabilitative as well as security responsibilities, to the contemporary, almost exclusive emphasis on security obligations for corrections officers, see Joshua Page, The Toughest Beat: Politics, Punishment, and the Prison Officers Union in California (New York: Oxford University Press, 2011), pp. 18-40. The California prison union's contention that corrections officers had the "toughest beat" in law enforcement was part of its successful effort to win pay parity with California Highway Patrol officers. Id. at pp. 38, 77.

35 Release dates are then determined by an administrative calculation based on the original sentence, goodtime credits and any other modifications for additional crimes committed while incarcerated. 
36 This is true, for example, in Florida. See Graham v. Florida, 560 U.S. 48,57 (2010).

37 See Mullane (2012), p. 147.

38 In re Lawrence, 44 Cal. 4th 288 (2008). In parole board decisions about prisoner release we often see great tension between the principles of punishment, largely retributive, that focus on the severity of the original crime, and the original concept of parole, often embodied in parole statutes, which focuses on whether a prisoner would represent a danger to society now if released.

39 See Michael Gottfredson \& Travis Hirschi, Age and Explanation of Crime, 89 Am. J. Sociol. 552-84 (1983).

40 See Michael Pinard, An Integrated Perspective on the Collateral Consequences of Criminal Convictions and Reentry Issues Faced by Formerly Incarcerated Individuals, 86 B. U. L. Rev. 623 (2006); Kinnaird \& Thompson, Offender Reentry and the Collateral Consequences of Criminal Convictions, 30 N.Y.U. Rev. L. \& Soc. Ch. 585 (2006). Marc Mauer \& Meda Chesney-Lind eds., Invisible Punishment: The Collateral Consequences of Mass Imprisonment (New York: New Press, 2002). For a listing of collateral consequences in every state, see Justice Center, Council of State Governments, Inventory of the Collateral Consequences of Convictions, found at https://niccc. csgjusticecenter.org/.Although the trend line is modestly down, the total number of persons on probation or parole supervision in the US remains high. At the end of 2015 , a total of 4.65 million adults were on some form of probation or parole supervision, or about 1 in 53 adults, in the US Bureau of Justice Statistics, Probation and Parole in the United States, 2015, Revised Feb. 2, 2017. https://www.bjs.gov/con tent/pub/pdf/ppus15.pdf. As of 2013, the US had five times the average rate of persons on probation of European nations. A. Corda \& M. Phelps, American Exceptionalism in Community Supervision, Perspectives, Am. Prob. \& Parole Assn., found at http://www.appa-net.org/Perspectives/Perspectives_V41_N2_P20.pdf.

41 Social science studies of sex offender and community notification laws have generally raised questions about their efficacy in reducing future sex offending by registrants. See Karen J. Terry, Sex Offender Laws in the United States: Smart Policy or Disproportionate Sanctions? 39 Intl. J. Compar. \& Applied Criminal Just. 113, 120-23 (2015). These laws may have a number of unintended negative consequences for registrants and their families which may increase the risk of future criminality and prevent registrants from becoming productive citizens. See id., E. Mustaine, R. Tewksbury, D. Connor \& B. Payne, Criminal Justice Officials' Views of Sex Offenders, Sex Offender Registration, Community Notification, and Residency Restrictions, 36 Justice System Journal 63, 64 (2015).

42 Maruna (2000), p. 99.

43 See Susan L. Miller, After the Crime: The Power of Restorative Justice Dialogues Between Victims and Violent Offenders (New York: NYU Press, 2011). 


\title{
10
}

\section{HEALING THE AMERICAN COMMUNITY}

\author{
Race and Criminal Justice
}

"You just don't get it."

No one likes to hear this, but how much these words sting depends on the speaker and situation.

When your kids tell you that you are clueless about their lives, you may sigh or grimace - or you may ask why-but you likely will not be devastated. You won't be emotionally crushed, even if there is some truth to the statement. (And there usually is.) Parents and children stand in different places in the world, making it hard to fully appreciate the other's situation. When men say this to women, or women to men, we may also accept that for all our efforts, our understanding of the other gender may fall short. We just seem to be built differently.

When the you-just-don't-get-it proclamation crosses race lines and concerns race, though, when the statement is made by a person of color and is directed at me or folks like me, meaning white people, it cuts deep. Especially for a white liberal it cuts deep. I have tried so hard to get it. Really. I could give you my good faith race credentials if you want. They go back years. No, you don't want to hear them? Okay. But really-after all these years of talk and soul-searching, after all of the stories and articles and books and documentaries and consciousness-raising programs, after all the protests and court cases and legislation, what could we still be missing? A lot, it turns out, and a lot that is critical to healing community. By community healing, I mean healing the wounds of past violence that discourage many from believing in justice, or the possibility of real peace in America.

In this chapter we consider a subject that has arisen many times before on our journey: race in American criminal justice. Our most serious community divides involve race, 
often in the context of criminal justice. I take up two current issues, one which has garnered enormous attention, and the other considerably less. The first is police use of deadly force against minority men, particularly young unarmed African-American men. The second is minority on minority homicides, particularly black on black killings.

I use these controversies to explore white views about race and crime and how these can block needed change. I am looking for why whites don't "get it" about race and even more, why we (whites/majority Americans) might not want to get it. This leads to a discussion about white views of America's racial past, present desires for racial separation and the nature of relational responsibility for race.

\section{Writing as a White Man}

I write now, as I have written this entire book, as a white man. In this I had no choice; I am a white man.

Like many whites in America, I resist identification as White. As a liberal, I know that white consciousness has long been associated with white supremacy, the ideology used to justify the conquest of native peoples and the enslavement, segregation and oppression of blacks. But that's not the real reason, if I'm fully honest, that I resist identification as White. I resist my whiteness, in a way that I don't resist other aspects of my identity such as maleness or American-ness, because of the social and moral burdens that come with this racial assignation. I don't want to feel bad for being White.

I hate the idea that I must carry personal shame or culpability for the past wrongs of others with pale-ish complexions. I would like to be seen for who $I$ am and not for what my appearance might signify. I want to be seen as a unique person and not a type. Isn't that what everyone hopes? It's an essential part of moral regard. It's what Martin Luther King meant, in his March on Washington line about hoping that his children would be judged on the content of their character and not the color of their skin. ${ }^{1}$

So I'd like not to go where I go here. But this is where the route to greater justice goes.

A fundamental lesson of our journey so far is that who we are depends on relationships with others, chosen and unchosen. All in the United States are engaged in race relations, like it or not. All of us have racial identities that are shaped in part by the expectations of others. Acknowledging personal racial identity is essential to doing justice under law and to relational justice. For whites this does not mean forever cringing in guilt or shame. But it does mean taking responsibility for more than our own individually chosen actions. It means taking responsibility for 
ingrained social attitudes and perceptions which we may never have chosen, but which still shape our lives. It means taking relational responsibility for race.

\section{The Urge to Forget and the Need to Remember: Race and Police Use of Deadly Force}

James Baldwin, one of America's greatest analysts of race, wrote of the necessity of accepting the truth of America's past. “To accept one's past-one's history-is not the same thing as drowning in it; it is learning how to use it. An invented past can never be used; it cracks and crumbles under the pressures of life like clay in the season of drought." 2

Especially when it comes to race, many Americans resist the past. We have always been big on today and tomorrow; yesterday, not so much, particularly if yesterday was a bad day. Unlike other peoples who carefully preserve memories of historical hurts, handing them down from generation to generation like treasured heirlooms, we Americans, by which I mean majority Americans, try to put the bad stuff behind us and, as we like to say, move on.

There is a major cost to American impatience with painful and shameful events, though. Violence teaches that if we do not remember past losses, if we do not speak their truth and mourn the lives taken, past hurts will haunt us. To live fully today, we must respect the hurts of long ago, even if the people hurt were not our people.

\section{A Los Angeles Story}

From my office window I can see some of the recent history of racial conflict and wrongful violence in Los Angeles. It is a hidden history, though, visible only to those who know the past.

When I moved into my fourth floor office in 1986 I could see a liquor store, a mid-rise glass and steel office building, a pair of time-worn tenement apartment buildings and La Curacao, a department store catering to Latin American immigrants. Now I look out on a law school campus that has expanded to include a basketball court, a broad lawn with trees, and the school's Girardi Trial Advocacy Center. Beyond, on the next city block, I can see the new Olympic Primary Center for preschool and kindergarten.

The differences between the view now and then may be traced in part to the effects of an early 1990s economic recession and the Northridge earthquake of 1994, but the biggest factor may be what happened following the 1992 acquittals of LA police officers for beating Rodney King. ${ }^{3}$ Without the fires that burned in the 
neighborhood, destroying the apartment buildings and damaging other structures nearby; without the looting and violence that followed the state trial verdict, it's hard to imagine the current view, because it was the consequent damage to property and faith in the city's future that opened the way for the new structures I see. Which means that without the videotape of King's beating replayed endlessly on the television news, and without the history of toxic relations between the Los Angeles Police Department and minority residents, especially African Americans, this view would not exist.

Another event that shaped this view was the killing of a 15-year-old African American girl, Latasha Harlins. On the morning of March 15, 1991, Harlins entered the Empire Liquor Market and Deli in South Los Angeles and picked up a $\$ 1.79$ bottle of orange juice. According to witnesses, she put the bottle halfway into her backpack and then approached the front counter with $\$ 2$ in her hand, apparently to pay for the juice. ${ }^{4}$

These were not good times to run a liquor or convenience store in South Los Angeles. It was a time of high crime in the city, with some of the most frequent and most violent crime occurring in then predominantly black South Los Angeles. The Empire store was run by Korean American immigrants, as were many liquor and convenience stores in South Los Angeles. Tensions between Korean Americans and African Americans had reached a dangerous state in the previous summer. African Americans complained of disrespectful treatment in stores owned and run by Korean Americans; Korean American owners and employees complained of crime and disrespect by blacks. The Empire market had been burglarized repeatedly and robbed three times. The eldest son, Joseph $\mathrm{Du}$, reported being terrorized by local gang members. Shoplifting was a constant problem at the store. ${ }^{5}$

On that Saturday morning, filling in behind the cash register was Soon Ja Du, a 51-year-old woman who had come to the United States from Korea. According to witnesses, Du accused Harlins of trying to steal. Footage from the store surveillance camera showed that $\mathrm{Du}$ reached over the counter and grabbed Harlins by her sweater. Harlins responded by punching $\mathrm{Du}$ in the face several times. Harlins then broke away from Du's grasp. Du hurled a small stool at Harlins. Harlins tossed the contested orange juice bottle on the counter and turned to leave. Du reached down and pulled from its holster a .38 caliber handgun that was kept there for the store's protection. She raised the gun and shot Harlins once at close range, hitting her in the back of head.

The gun's firing mechanism had been altered to give it a hair trigger. Du may not have been aware of this. At trial she said that the shooting was accidental.

$\mathrm{Du}$ was charged with first degree premeditated murder, but at the end of the prosecution's case, the trial judge reduced the highest charge to second degree 
murder. Although the trial was one of the highest profile proceedings in the county at the time and would normally have been assigned to an experienced jurist, it ended up with a recent appointee to the bench, Joyce Karlin. A former federal prosecutor, it was Judge Karlin's first jury trial presiding as a state judge. ${ }^{6}$

After four days of deliberations, the jury convicted Du not of murder but of voluntary manslaughter. Voluntary manslaughter is a serious felony generally punished by a significant prison term in California. Because Du used a gun, the maximum sentence in the case was 16 years in prison. But Judge Karlin placed Du on probation, meaning she did not serve any time behind bars. Du was also ordered to do community service and pay a fine.

In her sentencing decision, Judge Karlin emphasized Harlins's assault on Du, the past crimes that had been suffered by members of the Du family, the hair trigger on the gun and Du's lack of any criminal record. The judge said the offense involved "circumstances of great provocation, coercion and duress" and that Du's "overreaction" to Harlins was "understandable."

The judge began her sentencing remarks by rejecting the Deputy District Attorney's argument for the maximum sentence of 16 years. "Statements by the district attorney [which] suggest that imposing less than the maximum sentence will send a message that a black child's life is not worthy of protection, [are] dangerous rhetoric, which serves no purpose other than to pour gasoline on a fire."7

Many African Americans in Los Angeles saw the sentence of probation as clear evidence of a racial double standard: while black defendants convicted of crimes against nonblacks invariably received harsh sentences, whites or other nonblacks who victimized African Americans received little or no punishment.

The case fit a pattern of what I call mercy discrimination, where race plays its greatest role in deciding when the harshness of criminal law should be alleviated according to the individual circumstances of offense and offender. From investigation to sentence, the individuals most suspected of dangerous criminality - and race here contributes strongly to such suspicion-receive the full measure of law's punitive force. Crimes by persons whose characters are seen as less essentially "criminal" may be treated with greater leniency, for similar deeds.

When the white LAPD officers who beat Rodney King were acquitted by a largely white jury the following April, many black Angelinos saw this as nothing new. That was the problem. With the memory of Latasha Harlins's case fresh, it seemed like the same awful story, all over again. Black victimization did not matter. Again.

I remember standing in the law school café on the afternoon of April 29, 1992, at the back of a crowd of students, watching the verdicts come in on the television that hung from the wall in one corner. As the court clerk read off the not guilty, 
not guilty, not guilty verdicts from the verdict sheet, my gut tightened. So many times in the 1980s and 1990s the criminal justice system in Los Angeles seemed to fail us. Earlier that day, in the photocopy room, a fellow professor had asked me if I thought there was going to be trouble after the verdicts, which were expected shortly. I remember being surprised by the question. No, I didn't think so, I said. I had seen no signs of that. But by the time I reached home late that afternoon, it had started. I watched the beating of white truck driver Reginald Denny by a black man, Damian "Football" Williams. Williams had pulled Denny out of the cab of his truck at the intersection of Florence and Normandie and bashed him repeatedly in the head with a brick. Images of this violence were captured by a circling TV news helicopter and appeared on a small black-and-white television in our kitchen as my wife and I got our girls dinner. (What we did not see then was a group of African American residents put Denny in their car and rush him to the hospital, perhaps saving his life. ${ }^{8}$ )

As violence to person and property spread across South Los Angeles, the police department retreated. Across the city, but concentrated in South Los Angeles and Koreatown, stores were looted and burned; people were assaulted and shot. Over a three day span, more than 60 died as a result of the violence and fires, many businesses, especially those owned by Korean immigrant owners, were destroyed. ${ }^{9}$ I remember coming back to the law school when order was finally restored, thanks in part to the deployment of the National Guard, and wondering what the dark powder was on the outside stairs of our Frank Gehry designed main building. It was ashes from the fires in the city.

After the violence came a period of intense civic introspection. Why had this happened? How could this have happened in such a cosmopolitan American city, in the last decade of the 20th century?

After the 1992 riots, Los Angeles took on issues of race discrimination in policing. Two LAPD officers were later convicted on federal charges for the assault on King. There were major public investigations of the city's police department and the county sheriff's department, changes in police leadership, a change in the city's charter, and a Department of Justice lawsuit against the city over policing practices that was resolved by a consent decree. Today the makeup of the city's police department is far more reflective of the city's racial diversity. Police leaders work hard at community relations. And yet controversies over race and police use of force arise again and again. In recent years, Los Angeles Police Commission meetings have featured displays of extraordinary public vitriol over the issue. ${ }^{10}$

It would be an enormous mistake to believe that Los Angeles, or any other jurisdiction in the United States, has solved problems of race and police use of force. History tends to repeat here. Again and again controversies about police use of 
force against black men have triggered serious and sustained civic violence in the United States: see Baltimore, 2015, Ferguson, MO, 2014, Cincinnati in 2003, Los Angeles in 1992; Miami (Liberty City) in 1980. Other developed nations experience civic violence over political and economic differences; for Americans it seems to be race and use of force by police. Race is the great fault line in America's past which makes it the great fault line in society today. It remains our greatest barrier to the belonging needed for a peaceful and just community.

\section{The Shadow of the Past: Fear of the Police}

After the killing of Michael Brown in Ferguson, Missouri in 2014 and other controversial police shootings of African-American males, many commentators mentioned The Talk that black parents give their growing children about how to deal with the police. This conversation is often referenced in capital letters to signify its importance and ubiquity. Just as parents everywhere attempt to educate their children growing into adolescence about the mysteries and hazards of sexuality, black parents in America have seen the need to educate their children about police officers who may consider them threats because of their race. Parents teach African-American teen drivers how to act when stopped by police. They talk about how to keep hands on the steering wheel at the two o'clock and ten o'clock positions, how to remain calm and avoid angry, challenging responses. The Talk is preparation for an often fiercely administered police attitude test. The Talk is an education in racial fear. African-American parents teach their boys to be afraid of the police, because history teaches that a wrong move can cost a young black man his life.

The perceived necessity of The Talk has not changed even as cultural attitudes towards race appear to have changed, as local, state and national politics about race have changed, and as many big city police departments have become more diverse racially. Black parents educate their children about the dangers of the police because they believe, with reason backed by statistical evidence, that their children are at greater risk of being beaten or shot by law enforcement, because of their race.

White parents, and parents of other non-African-American children, do not have an equivalent talk with their children. In majority communities, the young are taught that the police are their friends. They can be trusted.

There is another kind of talk that white parents give children about racial dangers, however. This is a conversation, sometimes explicit, sometimes suggestive, about the connection between race and criminal violence. There may be comments about bad neighborhoods that need to be avoided, and the need to look out 
for unspecified bad people. Among the more educated, any explicit reference to African-Americans tends to be orally italicized with pauses and a lowered voice to signal a matter of great sensitivity. The adult's message is that: we're not racist and you shouldn't be either, but you do have to be careful. It's a matter of understanding that they — at least some of them, not all of them, to be sure-can be very dangerous. These warnings go more to girls than boys. The great fear expressed, by words or implication, is of sexual violence by black men. This is another form of education in racial fear.

A long history of race relations lies behind each of these talks. African-American parents can point to a history of racial discrimination, in which law enforcement has done the dirty work of a bigoted majority. White parents can point to a history of high levels of criminal violence in predominantly black neighborhoods. While these parental conversations anticipate future encounters, they draw on lessons from the past.

White people and black people in America are divided as much by history as by appearance. Different histories create different expectations and relational patterns. As a result, we have different perceptions of who and what is dangerous and who and what is safe.

Many whites become impatient, even angry, with recollections of past racial wrongs that put whites on the wrong side of history. They complain that the past, especially the distant past, should not be used as an excuse for present shortcomings. As Darren Wilson, the police officer who shot Michael Brown in Ferguson, Missouri, told a journalist much later: "What happened to my great-grandfather is not happening to me. I can't base my actions off what happened to him." He maintained that in police work, "We have to fix what's happening now. That's my job as a police officer. I'm not going to delve into people's life-long history and figure out why they're feeling a certain way, in a certain moment." 11 He said he was not interested in a federal report that documented pervasive and long-standing race discrimination in local criminal justice: "I'm not going to keep living in the past about what Ferguson did. It's out of my control.", 12 These value statements about the significance of the past, particularly our racial past, reflect a perspective shared by many white Americans today.

On this journey we learned early on about the present significance of past violence. How could anyone understand American public life today without appreciating the effects of the terrorist attacks of $9 / 11$ and subsequent attacks targeting Americans and westerners, from London to Madrid to Paris to San Bernardino? In comparison, race violence in this country has a far longer history, has taken far more victims, and is entirely domestic. It has all happened on our shores. Worst of all, this wrongful violence has often been condoned, and frequently committed, by 
public authorities, and then ignored, denied or rationalized by the majority. ${ }^{13}$ Of course this past still matters today.

\section{Going Back a Generation: Shooting Fleeing Felons and Patterns of Mercy Discrimination}

After notice of intention to arrest the defendant, [if] he either flees or forcibly resist[s] arrest, the officer may use all the necessary means to effect the arrest.

Statute on police authority to use of deadly force ${ }^{14}$

You cannot know the terror that black folk feel when a cop car makes its approach and the history of racism and violence comes crashing down on us. The police car is a mobile plantation, and the siren is the sound of dogs hunting us down in the dark woods.

Michael Eric Dyson ${ }^{15}$

To better understand present controversies over police shootings, I want to go back to a law that was in effect for many years in many parts of the United States. This law illustrates how mercy discrimination operated in the past, which will shed light on how it operates today.

When I was a police reporter in Jacksonville, Florida in 1978, officers regularly shot and killed felony suspects as they ran from officers. The typical case involved a white police officer and a teenage African-American boy suspected of a potential felony, who instead of obeying a police order to halt, tried to run away. The young man would then be shot, often in the back. Under the law of Florida and many states at the time- - see the Tennessee statute quoted above-it was lawful for police to use deadly force to capture a fleeing felon, regardless of the danger the suspect then posed. Police were instructed to shoot if no other means of capture seemed possible. In the newsroom we joked about police officers who practiced saying "Halt police, halt police, halt police" (these warnings being required by local police procedure) as fast as they could as training for shooting fleeing felons. Under these rules, a few patrol officers were responsible for a number of fatal shootings.

At least in the larger white community in Jacksonville, these shootings were accepted. Despite their frequency, they did not provoke serious protests. The assumption seemed to be that when the police yell at you to stop, you should stop, end of story. And if you had committed a crime and then got shot, well, you got what you deserved. The official law enforcement position was that the rule was required for deterrence. It was believed that without it, virtually all felons would run from police and some would get away. 
I do not recall any cases of unarmed white teens, suspected of felonies, being shot and killed by police, though it seems likely that such crimes, burglaries especially, were committed by both white and black teens in this city of half a million. Did white teens never run from the police? Or did police largely refrain from shooting when they did? I do not know.

The law on shooting unarmed and nonviolent fleeing felons changed in 1985, when the United States Supreme Court by a 6 to 3 vote in Tennessee v. Garner held that the Fourth Amendment of the United States Constitution prohibited the use of deadly force in these situations. The Court ruled that the police could not use deadly force to arrest except to capture a felon who posed a serious risk of death or great bodily injury to officers or others. ${ }^{16}$

The case that spurred this ruling followed the pattern familiar to me from Jacksonville. On the night of October 3, 1974, two police officers responded to a "prowler inside" call in East Memphis. One of the officers went to the back of the property where he heard a door slam and saw a teenager run across the yard to a 6 foot chain link fence. With the light from his flashlight, the officer saw the teen's hands and later said he did not believe that the individual was armed. The officer said that he believed the person to be 17 to 18 years of age and 5 foot 5 to 5 foot 7 inches tall. The officer issued a command to halt. After a moment's hesitation, the teen tried to jump the fence. Believing that the suspect would escape if he made it over the fence, the officer fired. The shot struck the teen in the back of the head, killing him. The teen turned out to be Edward Garner, a 15-year-old boy who stood 5 foot 4 inches tall and weighed between 100 and 110 pounds. He was in the eighth grade. In his possession was $\$ 10$ and a purse that he had apparently taken from the house.

Neither the majority opinion by Justice Byron White nor the dissent authored by Justice Sandra O'Connor mentioned race. They did not mention that Edward Garner was African-American, nor that the civil case about the shooting arose out of long-standing bitter conflicts between the black community in Memphis and its police department. They wrote as American judges often do, as if race was not an issue, and indeed it was not the critical legal issue. The legal issue concerned the police officer's constitutional authority to use deadly force against a person reasonably suspected of committing a nonviolent felony. And yet the Court's decision occurred in a historical context in which race was the story. ${ }^{17}$

At the time of the Court's decision, the old English common law's fleeing felon rule remained in force in a number of states, but predominantly in the South. This is potentially significant, as the South has a particular violence history concerning race: race slavery, race discrimination in criminal justice and racial terrorism. By racial terrorism I mean the organized use of violence, usually officially condoned, to 
kill, brutalize and threaten African-Americans and sometimes other groups such as Jews or Catholics, to effect political and cultural ends. Racial terrorism flourished in southern states from the end of Reconstruction in the 1880s until World War II and only dwindled in the 1950s and 1960s. ${ }^{18}$

Of course race discrimination in criminal justice was never confined to the South. Police use of extra force against blacks, the imposition of additional penalties against minority defendants by the courts, the disregard for claims of wrongful conviction of persons of color have occurred throughout the nation.

None of this background was referenced in the decision; the only history detailed in the Court's opinion was legal: accounts of 17th and 18th century English common law, the United States constitution, modern legislation and court decisions and police use of force policies.

In Garner the justices differed primarily about public safety. Justice White, writing for the majority found no need for police to use fatal force to capture apparently unarmed felons like Garner. Justice O'Connor disagreed. While she described the shooting as "deeply regrettable,"19 O'Connor believed the dangers of nighttime burglaries justified police use of all available means to capture suspects. She concluded that " $[\mathrm{t}] \mathrm{he}$ legitimate interests of the suspect in the circumstances are adequately accommodated by the Tennessee statute: to avoid the use of deadly force and the consequent risk to life, the suspect need merely obey the valid order to halt." ${ }^{20}$ If Garner had stopped atop that fence, he would have lived. If he had just trusted the police and the legal process, he would have lived. ${ }^{21}$ Note the classic expression of the autonomy ideal: an individual is held responsible for his or her own choices, regardless of the larger social context. Youth, race, history-none of these matter.

To appreciate this decision historically, we need to supply the context that the Court left out. The following are facts about Memphis police, use of force and race discrimination that were available to the Court at the time.

When Garner was killed, the Memphis police department had no formal shooting policy; it did not provide formal training in shooting for its officers. The only limits placed on officers were those of state law. Individual officers had discretion whether or not to shoot an unarmed suspect fleeing the scene of a possible felony. New officers were told that they just had to live with themselves if they killed someone. ${ }^{22}$ Underlining the free rein given city police officers at the time, it appeared that no Memphis police officer had ever been disciplined for improper use of a gun. ${ }^{23}$ Unsurprisingly, given American history, this broad discretion was not exercised in a racially neutral fashion.

From 1969 through 1974, 85.7 percent of those shot by Memphis police were black; 14.3 percent were white. ${ }^{24}$ Compared to their percentage of the Memphis population, blacks were ten times more likely to be shot at by police when 
suspected of property crimes than whites, 18 times more likely to be wounded and five times more likely to be killed. Focusing just on rates of police shootings of those suspected of property offenses, the rate for blacks wounded by police gunfire was six times higher than the rate for whites. The death rate for blacks shot by police while unarmed and nonassaultive was 18 times higher than for whites. ${ }^{25}$

In retrospect, the Court's conclusion in Tennessee $v$. Garner seems obviously correct. Of course using deadly force to seize a person suspected of a nonviolent offense, who presents no dangers to others, amounts to excessive force. This seems very much like an unreasonable seizure of the person under the Fourth Amendment. And when we consider contemporary controversies over police use of deadly force in cases where officers claim self-defense, a much more powerful moral and legal claim, it seems almost unimaginable that the law permitted and police departments encouraged officers to shoot unarmed, non-dangerous fleeing suspects just to effect their "arrest."

Thus we might take solace in how much has changed in American policing since Garner's shooting. Even by the time the Court handed down its decision, the Memphis Police Department had an actual shooting policy. As a result of the Garner decision, the law of shooting fleeing felons changed nationwide. No contemporary US police department does, or could, wield deadly force with such abandon and with such racially disparate results as did the Memphis police in the early 1970s. From these developments we might reach certain reassuring conclusions about our present race situation. We have learned a great deal about race and policing since the early 1970s. We have grown as a nation. We have fixed, mostly, what needed to be fixed. Which means that it's time to move on from this old controversy. Right?

But if we move on without looking beneath the surface of this history, we will miss its most important lessons. We need to ask tougher questions. Why did this rule of law persist for as long as it did? Why did it have such strong support among those in law enforcement and elected officials, among voters and even among Supreme Court justices in 1985 (there were three dissenters), long after the signal accomplishments of the civil rights movement some two decades earlier?

The answer involves moral regard. Who are seen as individuals, and who are seen as types? Do we see the person shot as a suspected felon, or as person suspected of a crime? Is he a burglar or a boy? Obviously he can be both, but what we initially perceive often dictates our moral—and legal—conclusions. Memphis's mayor at the time defended the police department's shooting practices this way: "[Y] ou let him get away, tomorrow he's in another place stealing guns and maybe the next week he's in the 7-11 blowing somebody's brains out. I'm just a strong man on feeling that a felon is a felon and if you commit a burglary you will step up gradually to 
something else." 26 Notice, the mayor did not mention race here; his justification was entirely about crime, violence and public safety. That does not mean that race did not matter, however.

A thought experiment may help here. Imagine a city where whites comprise the majority and hold a firm grip on political, social and economic power. Imagine that significant numbers of unarmed white teens are shot fatally in the back while fleeing from the scene of suspected business or residential burglaries, where there is no violence but a small amount of property is taken. Would these fatal shootings be seen as fully justified by most citizens and their elected representatives? Or would there be, in fairly rapid order, popular demand for changes in law and police practice with respect to use of deadly force? Might we expect even greater public concern if it was revealed that the police receive no specific training in when to shoot? Might that criticism grow on learning that the department uses soft-point (dum-dum) bullets because these bullets inflict the maximum damage on human targets? ${ }^{27}$ And if there would be a public outcry in this situation, but there was little or none when young blacks were shot and killed - under the same circumstanceshow can we say that race made no difference?

In the American criminal justice system, race disparities follow a standard pattern. Where the severity of criminal law falls primarily on minorities, severe treatment seems justified - to the majority. Criminals just get what they deserve under the law. When those who are judged to have "made a mistake" face harsh penalties for criminal violations, however, the exercise of discretion suddenly seems necessary to do justice. Police, prosecutors, or judges find ways to ameliorate the potentially harsh rule of law. Because obviously its full severity was not intended to fall on someone who just made a mistake.

The problem is that because of race, some suspected of wrongdoing are presumptively seen as criminals, while others are seen as persons who made a mistake. Because of this difference in character perception, the same rule of law can produce different results according to race. This is what happened with the rule allowing the shooting of fleeing felons; it's what happens with many other rules today. The doctrinal particulars may change but the pattern of selective application remains the same.

Seen from today's vantage, the wrongs of our racial past are clear. And so we may say to ourselves, well, we're never going to do that again. And if we define what occurred in the past narrowly enough, that may be true. But the real lesson of the past comes in understanding what made it seem right or acceptable then. Because similar justifications will appear today, in slightly different circumstances, expressed in slightly different ways. We need to examine past failures to alert us to contemporary dangers; they should not reassure us of our present virtue. 


\section{Respecting the Past through Remembrance}

Victims of violence know about anniversaries. The anniversary of a sexual attack, the birthday of a loved one who was murdered, or the date of her death, can bring emotional storms even decades later. At least on these days, the past is very much present. Most victims learn about the necessity of acknowledging anniversaries. Even as survivors move forward, anniversaries must be marked.

The other group with a keen appreciation for the need to honor past losses is the military. All branches of the military have rituals of remembrance both formal and informal, some to be done almost immediately and others much later, to honor lives taken by violence. We see a similar reverence for violent loss at the funerals of police officers killed on duty and, at their best, in public holidays to honor the military's dead, such as Memorial Day in the United States. Notice, though, that these are remembrances of majority suffering. They are not commemorations of suffering inflicted by the majority.

What if we had a day, or even just a designated time on a designated day, to remember lives lost in past racial attacks in America? This would be a time to acknowledge losses in both body and spirit. It would not be an occasion for recrimination or shaming, but acknowledgment, acceptance and accompaniment. I'm not sure this should be a day off from work or school, for such holidays quickly become excuses for sales events and sporting contests, with only passing recognition of their original purpose. This would be a time for sorrow and stillness. I imagine a time like when the siren sounds in Israel at 10am on the morning of Yom HaShoah, a day set aside every year in that nation to remember the Holocaust. Another example is Germany's commemoration of the Holocaust by prominent markers of places where Jews and their property were taken. Or the project of Bryan Stevenson and the Equal Justice Initiative, to commemorate lynchings in the United States. ${ }^{28}$

The great obstacle to a broader remembrance of race violence is the American belief that we are morally special, an exemplar for the world. We celebrate our past victories, not our past losses. Formal remembrance of the ugly past would require us to sacrifice our historically-rooted sense of moral election. We could not use the glories of the Declaration of Independence (all men are created equal) and the constitution to erase memories of race slavery and colonial conquest. We could not erase past attacks on native populations, both direct and indirect, by celebrations of immigration, past and present. We would have to, at least for a time, admit that our past contains much of the same moral darkness found in the pasts of other nations.

To which the impatient reader may reasonably and forcibly object that all this remembering will do little to address immediate concerns with police use of force. 
What does some general commitment to recalling past wrongs do for outraged communities and devastated families? Or, for that matter, what does it do for police officers who feel themselves under moral, physical and political siege? Where in this is the need for better police training on use of force, including a greater emphasis on conflict de-escalation rather than confrontation and unconscious bias training? Where's the consideration of civilian oversight boards or use of police body cameras? Most importantly, where is the discussion of the proliferation of guns in America, which is the underlying, foundational fact of law enforcement in the US that makes every citizen-police interaction potentially deadly in a way that is not true in any other developed nation? ${ }^{29}$

These are critical issues in addressing police use of deadly force. But I have used this controversy on police use of force as a window into the larger question of what we whites often miss about race and criminal justice. An important part of the answer is, the weight of the violent past for African-Americans. The same is true for Native Americans. That is a weight that most whites do not feel, but need to appreciate if we are truly committed to equal justice for all.

To understand where the present level of black outrage comes from, and to resist the temptations to become defensive ( am not a racist-how dare you say I am), or to retreat from the discussion entirely (just forget it, I'm out of here), we need to respect the past. This means respecting our overlapping but very different pasts. Because of our radically different pasts, whites and blacks stand in a different place in America today even when we physically occupy the same space and even when we share the same apparent social status. It's a basic truth, easy for whites to forget, almost impossible for people of color.

\section{Defining Us: White Views of Minority on Minority Homicide}

What about the poor black child that is killed by another black child? Why aren't you protesting that? ... Why don't you cut it [black on black violence] down so many white officers don't have to be in black areas? ... The white peace officers wouldn't be there if you weren't killing each other 70-75 percent of the time.

Former New York City Mayor Rudy Giuliani, debating Michael Eric Dyson on the protests against police use of force in Ferguson, Missouri ${ }^{30}$

To yell "black-on-black crime" is to shoot a man and then shame him for bleeding. Ta-Nehisi Coates ${ }^{31}$

Police use of deadly force is statistically exceptional. Many police officers go their entire careers without firing their weapons except at the shooting range. 
Police homicides of unarmed black or brown men are even more unusual as a statistical matter.

By contrast (and there is a great deal, we will see, in deciding to make this contrast), young black men shooting and killing other black men happens with some frequency in major American cities. Latino young men doing the same to other Latino young men is also common. This happens on Chicago's Southside, in South LA and East LA, in New Orleans and Detroit and Philadelphia and many other cities.

In terms of numbers, police shootings constitute a tiny part of the problem of deadly violence in the most stressed urban communities in America. The great majority of young African-American and Latino males who are shot, are shot by men like themselves, not by the police. And so some have argued, as Rudy Giuliani did above in the quote above, that the real violence problem facing minority communities is not police violence, but minority violence resulting from the dysfunction of family and community structure in some minority communities. ${ }^{32}$

Most of the time, minority on minority shootings and killings receive little public notice. Most are not reported in any detail, or even mentioned at all, in the daily newspaper or on the nightly news. If the death numbers add up to a particularly sensational total, or the person killed is an especially sympathetic figure, such as a small child, a pregnant woman, or a teen going to school (maybe) then the majority may take notice. In this very basic sense, black on black homicides do not matter much to majority (predominantly white) America.

And yet the subject of black on black homicide comes up with regularity in the discussion of race in criminal justice, often when race discrimination by police has been asserted. It's a revealing juxtaposition. The killing of young people in certain urban communities is certainly a major public safety and justice issue in modern America. It has huge economic costs. But why should this be considered a question of race- and what does it have to do with police conduct?

There are many non-racial ways of framing issues concerning high rates of urban homicide today. We might ask about killings of young men by young men, because that is the standard pattern. We might be interested in killings by firearms, as guns take the most lives. We might want to study killings by geography, as most of these killings occur within relatively small geographic areas. We might highlight poverty or education issues (the correlation between school problems and youthful violence is particularly striking) or family dysfunction including mental illness and substance abuse, child abuse and neglect, or the absence of a father figure in a boy's life: all frequently appear in the backgrounds of perpetrators. We might focus on killings by gangs, because a great deal of minority on minority homicide is gang-related.

Asking about race in homicide means that we seek a race answer, at least in part. This may be because we are interested in assessing race fault to rebut racial 
criticisms of police. As in, no, what's happening is not the police's fault, it's your fault. This suggests an effort to find a racial group, or at least a part of that group, socially or morally responsible for these homicides. Another explanation might be that we choose to focus on race because it seems to play an important role in homicide dynamics and therefore can play an important role in homicide prevention. As we proceed, we will need to keep in mind the question of why race should be highlighted here.

\section{Race Differences in Homicide}

There are a few basic facts about violent crime in America that have persisted over decades. The US has a higher homicide rate than other developed nations and more firearms offenses. Violent crime is committed at higher rates in the South and the West than in the Northeast. And African-Americans commit homicide and are victims of homicide at significantly higher rates than any other race.

Homicide is and has always been a largely intra-racial offense. While cross-racial killings are the most publicized-particularly if the victims are white-for the most part, whites kill whites, blacks kill blacks, Latinos kill Latinos—and men kill men (although they also kill plenty of women, it must be said). With relatively small yearly variations, some 90 percent of African-Americans killed were killed by African-Americans; roughly 82 percent of white victims of homicide were killed by whites. ${ }^{33}$

Proportionally, African-Americans are far more likely to be killed than persons of any other race in the US. For 2015, over 50 percent of homicide victims in the country were black, although African-Americans made up just 13.3 percent of the population. ${ }^{34}$ By contrast, whites, who comprised 77 percent of the population made up 43.5 percent of the victims of homicide.

The race of homicide offenders roughly tracks the percentages of victims, consistent with the intra-racial nature of homicide. In 2015, for those homicides where the race of the offender was known, 36.7 percent of offenders were African-American; 30.2 percent were white, 12.7 percent were Latino or Hispanic. (Reflecting the fact that many homicides go unsolved, the race of the offender was unknown in 31.2 percent of reported cases.) ${ }^{35}$ From this we see that African-Americans commit a disproportionate number of homicides compared to their overall population numbers.

There are many explanations for race disparities in American homicide, just as there are many explanations for huge gender differences in homicide commission, age differences, geographic differences and even differences according to time of day and season of the year. But any account of race disparities in homicide today 
must begin with our history of race violence. The highest contemporary rates of violence are found in the two race groups, African-Americans and Native Americans, who have experienced the worst race violence and oppression in the past and whose status in the larger American community has always been intensely contested by the majority.

The race disparities for homicide parallel race disparities in socioeconomic status, physical and mental health, education and housing. ${ }^{36}$ High levels of homicide occur in highly stressed communities where fierce competition for belonging, economic and social, inspires cultures of violence. ${ }^{37}$

An important piece of the puzzle from a criminal justice perspective is the relative ineffectiveness of homicide investigations in urban minority neighborhoods. Although the rates vary by city and police department, minority on minority homicides are solved at a lower rate in the United States than other homicides. ${ }^{38}$ Unsolved homicides increase the chance of future violence, both by uncaught perpetrators and by those retaliating for the homicide. They also deepen the sense of exclusion, isolation and grievance in communities that feel simultaneously abandoned and oppressed by the police.

In some minority neighborhoods, many residents assume that the police do not care about solving homicide cases if the victim is black or brown. They have reasons to believe this. The level of police attention and the attitudes of responding officers, particularly patrol officers, suggest as much. ${ }^{39}$ Resources for homicide investigation in minority communities can be astonishingly paltry compared to the need. Finally, as noted before, clearance rates for homicides in minority communities are low. Without arrests, there can be no prosecutions, convictions or punishment.

Police respond that low clearance rates for homicides in minority neighborhoods are not due to lack of diligence on their part but lack of cooperation on the community's part. After killings that happen in public places that are witnessed by many, frequently no one will admit to seeing anything. Identified witnesses do not speak forthrightly. Despite what we might see on television, most homicides are not solved by physical evidence; arrests and convictions depend on witness accounts. If they won't talk to us, how is that our fault? A lack of trust in the police and a general culture of noncooperation with police in minority urban communities undoubtedly contributes to low success rates in crime solving. $^{40}$

In many cities a powerful negative feedback loop has taken hold. Community members do not trust the police based on prior mistreatment and so provide little cooperation with investigators, which angers and frustrates the police, who come to accept low clearance rates as a result, which leads to further community distrust, 
including a sense that killers in the community have legal impunity. This leads to greater incentives for violent retaliation, which worsens the homicide problem. The police won't do anything; we have to take care of this ourselves. Jill Leovy, a journalist who embedded with homicide detectives in South Los Angeles, has asked us to imagine the response of white teens to the situation faced by many black teens in high-homicide neighborhoods:

Take a bunch of teenage kids from the whitest, safest suburb in America and plunk them down in a place where their friends are murdered and they are constantly attacked and threatened. Signal that no one cares, and fail to solve the murders. Limit their options for escape. Then see what happens. ${ }^{41}$

Minority on minority homicide represents a serious justice problem in America today, perhaps our most serious justice problem involving criminal violence. But my concern remains what white people don't get about race and criminal justice, which prompts the question, what do majority Americans think about minority on minority homicide? Consistent with the approach taken in this book, I begin asking this question with respect to victims. What do majority Americans think about the victims of minority on minority homicide?

\section{A Difference in Value According to Race}

The plight of those most hurt by violence should be at the heart of criminal justice. The race of a violence victim should not matter. Who would say that the killing, or rape, or robbery of a person of one race is worse than the same violence against a person of another race? And yet the strongest evidence we have of race discrimination in criminal justice in America today involves different treatment according to the race of the victim.

From death penalty sentencing to resources for homicide investigations to media attention, the story is the same: killings of people of color appear less blameworthy to legal decisionmakers and less noteworthy to the public than the killings of whites. The first time I saw this was when I covered state courts in Jacksonville, Florida and noticed that the State's Attorney almost always charged criminal homicides with black victims (and usually with black defendants) as second-degree murders, while those with white victims (regardless of the defendant's race) were charged as firstdegree murders.

In earlier chapters we saw how in recent years we have tried to help victims of violent crime through increasing punishment for convicted offenders. We have also 
seen how this effort may speak more to our emotional needs than to the deepest needs of victims. We have seen how survivors need security, accompaniment and mourning to heal. In this chapter we have seen how low clearance rates for homicide investigations in minority communities contribute to ongoing violence, a major security concern. But what of accompaniment and mourning for victims of minority on minority homicides?

America knows how to accompany and to mourn outrageous violence. It seems that almost every month, and in a bad month, almost every week, brings some terrible mass violence episode that inspires vigils and memorials and personal remembrances of those taken. We know the drill. When wrongful violence does not come in some extraordinary form, though, and when it takes people we do not know, who live in a place we do not know very well (even if it is close by) and especially if the victims do not seem to be entirely "innocent," most Americans swiftly move on, assuming they notice at all. Under these circumstances a local murder will mean less than the chance of rain in the forecast. A lot less.

In majority communities, the murder of a Steve inspires more concern than the slaying of a Ta'Quan; a John more than a Juan. Can you can recall a murder making the headlines when the victim was a young black man or Latino? Especially if his likely killer was of the same race? Have there ever been any contenders for the crime of the century, or decade, or even the year, where the victims were not white? White deaths really do matter more to the majority in America than do black deaths.

Some may say that this is just human nature. Everyone, on some level, cares more for their own. Their own nation, town, school, team. Their own family. Surely there is a limit to how much we can care about what happens to strangers. Caring about every victim of wrongful violence would lead to emotional paralysis.

While there is truth here, it should be a very uncomfortable truth. Remember, we are now concerned with minority on minority homicides in our own cities and states, not across the country or across the world. And we are talking here about a difference in caring about victims according to race. Also, it must be said, often according to class.

The difference in caring about murder victims illuminates where black and brown minorities stand in majority white America. They stand over there. They do not stand with us. We do not want to stand with them.

The differential in concern suggests that for whites, black membership in the American community is contingent, dependent on proof of individual value or special claim on our sympathies (the elderly, children, a recently returned veteran). White membership in community is presumed and may be lost—if at all—only on proof of serious individual wrongdoing. 


\section{How is This My Problem? Or, White Dreams of Separation}

Given that the worst homicidal violence in most cities is intra-racial and occurs in minority communities, given that significant (though far less than optimal) law enforcement resources are deployed in such communities, many who live in safer areas, especially if white, may think to themselves: of course this is awful. It's just terrible to see young people killing each other so senselessly. Better schools, better housing, more jobs, well, maybe that would help. But stopping the killing-isn't that really up to them? Honestly, what can we do about that? How is this my fault? How is this my problem?

Note again the significance of the pronouns used: them and $u$ and $m y$. These pronouns are simple but powerful indicators of belonging and exclusion. These simple pronouns raise the question of who counts as us in America. It's a question we have been struggling with from the very beginning of America.

From the earliest European settlement, the white peoples of America have dreamed that this land would be their place of freedom and prosperity. If this sounds strange and malignant, let me shift to the first-person plural more standardly used in American accounts of the past: Our ancestors came here seeking opportunity and freedom, and through their efforts and sacrifice, they bequeathed to us precious gifts of freedom and opportunity.

But who, exactly, is this us, this we, this our?

The abolitionist and former slave, Frederick Douglass became one of the first to publicly question how America defined itself racially. In his "What to the Slave Is the Fourth Of July?" delivered in Rochester, New York on July 5, 1853, Douglass distinguished between the legacies of American independence for white citizens and black slaves. Speaking to a predominantly white, antislavery audience, he declared, "the 4th Fourth of July ... is the birthday of your National Independence, and of your political freedom. This, to you, is what the Passover was to the emancipated people of God." He carefully delineated the moral and political achievements of the nation's leaders in throwing off English rule. After further prologue, he transitioned from third person to first:

I say it with a sad sense of the disparity between us. I am not included within the pale of this glorious anniversary! Your high independence only reveals the immeasurable distance between us. The blessings in which you, this day, rejoice, are not enjoyed in common. The rich inheritance of justice, liberty, prosperity and independence, bequeathed by your fathers, is shared by you, not by me. The sunlight that has brought life and healing to you, has brought stripes and death to me.

Then having built up a powerful head of rhetorical steam, Douglass turned to the title of his address. He asked, "What, to the American slave, is your 4th of July? I 
answer: a day that reveals to him, more than all other days in the year, the gross injustice and cruelty to which he is the constant victim."

From the earliest days of what would become America, white settler hopes of freedom and prosperity depended on white ownership and control. Efforts to eliminate, dominate, segregate or move nonwhite peoples were integral to achieving the (white) American dream. It's true that this was now a long time ago. In American historical terms, the conquest of native tribes seems like ancient history. Racial slavery is also long gone. The rule of racial segregation that was law for so long in the South and an organizing principle of social life in the North and West, is history too. In the work force (mostly) and in culture (mostly) and in politics (sometimes), the people of America are diverse. Look, we've even elected a black President, twice!

But facts on the ground speak another truth. Whites still prefer-strongly prefer-race separation in the most important personal spaces of their lives. Neighborhoods and churches and elementary schools and middle schools and high schools are still largely segregated by race. Public schools, for example, are as racially segregated today in many parts of America as they were at the time of the Brown v. Board decision. Many high paying industries, most notably high tech, employ few black and brown workers. Many whites have few personal relationships with black people and even less contact with the black community.

Many Americans believe that this state of race separation is fine. It is the morally neutral (on its own, neither good nor bad) product of free choice: people living where they want to, among the people they feel most comfortable with. It reflects a personal preference, like choices in cars or music or movies or clothes or food. It's a free country; we get to choose. Except that the freedom to live where one wishes, limited only by affordability, is a freedom enjoyed far more by whites than by blacks. Except that the freedom to choose the best schools for children is a freedom enjoyed far more by whites. That is because most neighborhoods remain racially segregated less because of contemporary choices about where parents of color want to live, than a history of intentional segregation decisions by financial institutions, developers, and government officials throughout the country. ${ }^{43}$

Racial separation is not a morally neutral act when it replicates and reinforces historical patterns of race discrimination. Racial separation is not a morally neutral act when money and power concentrate with some racial groups and not with others. It is not a morally neutral act when separation brings great differentials in economic opportunity, educational opportunity, quality of housing and health services. During the civil rights struggles of the mid-20th century, Northern liberals scoffed at Southern pretenses of separate but equal, pointing out the obvious ways that Jim Crow segregation created and enforced inequality. Today legal segregation 
is gone, but the appeal of separate but equal remains, everywhere. Then, as now, racial separation and equality are enemies.

Minority on minority homicide has a distinct geography. It occurs primarily in minority communities where racial segregation was in the past enforced by law and violence. Especially for African-Americans it occurs in places of historical concentration, which are also places of exclusion from the rest of the community. Given all that we have learned about violence and its intimate association with notbelonging, that it should thrive in such places should not surprise.

A white preference for racial separation makes accompaniment of black homicide survivors and mourning for black victims almost impossible. How can we feel for their loss if they live over there, where we will not go? How can we call them to belonging with us if we are committed to their not-belonging? Can't be done.

\section{Separation and White Fear of Violent Crime}

But what about race separation that comes from legitimate fear of violent crime? We know the cost of wrongful violence. I have mentioned before the need for violence prevention. To the extent that racial separation, especially residential, is linked to fear of violent crime, how is that wrong? No one wants to live in a high crime neighborhood if that can be avoided and predominantly African-American neighborhoods generally have higher crime rates. Look at way they kill each other. I'm going to do whatever I need to protect my family. Including living in a safe neighborhood and sending my kids to safe schools. If that leads to race separation, so be it. But don't blame me for what other people are doing.

In Chapter 3 we first encountered the problem of race fear. We saw there the power of race to exaggerate fear in decisionmakers. It's not that race is entirely irrelevant to statistical assessment of risk; like gender and age and class, it has some predictive power. The problem is that unlike these other categories, our race-based fears almost always go beyond the evidence in practice. In assessing risk in particular cases, which is the critical task for criminal justice decisionmakers, intuition based on race proves faulty, again and again. In this regard it's also worth noting that our current concern is with black on black homicide. Those most at risk of being killed by a black man - by far-are other black men. Not whites.

We must also confront the close relationship between separation and fear here. Race separation may result from racial fear; race separation also fosters it. Living in separate neighborhoods and sometimes behind gates, barred windows and in homes with private security systems would seem to provide extra protection from outside threats. Many people, from real estate agents to security companies to politicians, sell this promise to receptive listeners. But by providing a constant reminder of the 
apparent threat of outsiders, separation can increase anxiety and fear. It is possible to heighten security and fear at the same time.

And yet for all this, the race-violence link in America is real. It is a fact of American life. Minorities suffer more from this race differential in wrongful violence than do whites, but whites are victims as well. And all wrongful violence must be taken seriously. Taking violence seriously is a fundamental of justice. Reducing levels of minority on minority homicides should be a priority for all because it affects all, directly or indirectly.

\section{The Impossibility of Relational Separation}

Physical separation of the races may occur in America, but relational separation is impossible. We are in racial relationship, even if we do not personally interact with persons of another race. President Lincoln's words issued in 1861 to the southern states that had either seceded from the Union or were contemplating secession, could also apply to the races in America today.

Physically speaking, we cannot separate. We cannot remove our respective sections from each other, nor build an impassable wall between them. A husband and wife may be divorced, and go out of the presence, and beyond the reach of each other; but the different parts of our country cannot do this. They cannot but remain face to face; and intercourse, either amicable or hostile, must continue between them. ${ }^{44}$

No one can opt out of race relations in America. We can physically separate, but that only changes the nature of our race relations, it does not end them.

Many Americans, mostly but not all white, claim immunity from any relational responsibility for race, citing personal freedom. Everyone is responsible for their own choices. If I do something wrong, I gotta take the consequence. But if I don't do anything wrong myself, then somebody else's hard time is just not my problem. It's a free country.

Once more, talk of individual choice proves misleading because it ignores relational realities. In relationships, choice is real, but limited. Like family relations, our race relations have certain features that were established long before we came on the scene. We have to deal with the race, class, gender and other relational patterns in which we find ourselves, with all their pre-existing complexities. We must choose how to respond to relational dynamics, but with very few exceptions, we cannot, by ourselves, transform those relations. They are bigger than any individual. 
Finally, it turns out that the independence we say we want may not be what we truly desire. Turns out that majority Americans are also vulnerable to feelings of racial exclusion. We also may feel a need to belong that depends on others.

\section{White Need for Belonging in America}

Whether I like it or not, or whether you like it or not, we are bound together forever. We are part of each other. What is happening to every Negro in the country at any time is also happening to you. There is no way around this. I am suggesting that these walls - these artificial walls-which have been up so long to protect us from something we fear, must come down.

James Baldwin ${ }^{45}$

On my sabbatical in 2013-14, I filled in occasionally on Sunday for the Protestant chaplain at the Greene Correctional Facility in upstate New York. I led worship services for a predominantly black congregation of inmates.

In taking on this new role, adjustments had to be made on all sides. The men had to assess this Episcopal deacon, in part to make sure that I wasn't really Catholic. (In prison there is an important, perceived, divide between Catholic and Protestant.) I had to figure out the men's worship expectations and needs. And then there was the race thing. I specifically addressed our race differences when we did a special service to honor the birthday of Martin Luther King, Jr. I noted that I was white and that King was an important figure in my life, which he is. The men appreciated the celebration, as did the regular chaplain who was able to attend that service. It was not something that had been done before.

On my last Sunday at Greene, several months later, we said our goodbyes and talked about our time together. I said how much I appreciated their acceptance of me as a white man. One of the men joked that I was "white even for a white guy." Something about how I dressed and spoke, I think.

The generosity of the men at Greene in accepting me, in seeing me for who I was (at least a part of who I was) and not the type that I presented, moved me greatly. I was-and am-socially clueless sometimes, including about race. But in that large, over-heated, and unadorned room on those Sunday mornings, I belonged for a time, which felt like a gift beyond words.

Looking back at this experience, what strikes me is not that we achieved racial harmony in our times together, or even any great cross-racial understanding. There was so much about them I did not know and so much about me they did not know. Our many differences were not tested by the need for hard decisions or actions. What strikes me is how much I wanted their acceptance. I really wanted them to like 
and accept me. I think this mirrors a larger white need for black acceptance that we have seen from the very beginning of our racial history. We can see this in the passionate insistence of many white slave holders that they had a wonderful and even loving relationship with their slaves. We can see this in their sense of betrayal when after slavery ended, freed slaves began to speak and act freely—and without a second thought left their former masters to fend for themselves. ${ }^{46}$

Looking back, I see that it's also possible that the inmates responded to me as they did because they wanted me to accept them. As prisoners of color (mostly), to be accepted by a white man from the outside world, from a respected institution like the church, might have been important. Prisoners experience a great deal of rejection by majority (mostly white) society.

A need to be accepted by persons of another race is hard to admit in the contemporary United States. We Americans are an independent and proud people. We don't need anyone else to accept us to know our own value. We do not want to give any other group that power over us. African-Americans have especially strong reasons for rejecting dependence on whites.

Speaking now just as a white man, it seems to me that whites cannot fully belong in America without the assent of people of color, particularly African-Americans. Regardless of political and economic power disparities, minorities hold the key to full belonging for the majority. Why else would minority accusations of bigotry and cluelessness cut white people in America so deeply? These same accusations made by nonAmericans we easily reject. Only when they come from our own people-yes, our own people - do they really hurt. Again a relational truth emerges from the conflict. We are connected, intimately.

The moral power that people of color hold over whites is just what many whites want to deny. This denial may be expressed in efforts to separate. I think it lies behind a great deal of the racial tension felt by white Americans. But in this most uncomfortable truth about connection, we should also find hope. We cannot be who we want to be without the other. ${ }^{47}$

\section{Conclusion}

Race is the ghost in the machinery of American criminal justice. It appears everywhere and, simultaneously, nowhere. From certain perspectives, race bias seems pervasive, ubiquitous. Look at who is in prison, at who is in jail, at who receives the worst treatment from law enforcement. Look at how the present criminal justice system replicates many of the worst features of past racial oppression.

From other perspectives, though, the significance of race for criminal decisionmaking almost seems to disappear. Race differentials in arrests and punishment 
mostly reflect race differences in rates of offending. Even if current race disparities can be traced to past discrimination, system defenders argue that all that matters is whether the criminal justice system discriminates today. And mostly, it does not.

Occasionally racial bias will be caught in the act. As if captured by a camera's electronic flash, bias will be starkly recorded, allowing us to see how it affected criminal judgment. Then we can confidently respond with righteous indignation. Got you now-you're not getting away with it this time. But more often the significance - and even existence - of race bias in American criminal justice depends on where we stand. It depends on where we stand today, where we stood yesterday, and where we expect to stand tomorrow. In each case, our location depends significantly on race. It depends on the imagined color of "we."

People like me, meaning white folks, will never entirely get it when it comes to race in America. There is too much difference between the white experience and the experience of people of color for complete understanding. But recognizing the intractability of our differences does not ease our relational responsibilities. Tragedy does not excuse. And we must not give up on justice just because its full achievement seems beyond our present grasp.

To heal the American community from past race violence, we need to remember and accept the worst of our past, which is the past of all of us, and to appreciate its present significance. It lives with us today.

Creating just relations in the American community requires engaging across race lines: speaking honestly and listening closely. We must have hard conversations in which we speak the truth as we understand it, never denying another person's experience or dignity. In striving for justice this way, we have our best chance for building a greater peace.

\section{Notes}

1 Martin Luther King, "I have a dream that one day my four little children will one day live in a nation where they will not be judged by the color of their skin but the content of their character." August 28, 1963, Address to the March on Washington.

2 James Baldwin, The Fire Next Time (New York: Vintage, 1989, 1962), p. 81.

3 To be precise, the jury acquitted on all counts except one; on that count, the jury could not reach a unanimous verdict. I refer to the verdicts as acquittals here because that was their effect. There was no further state prosecution against any of the LAPD officers. Federal authorities subsequently brought criminal civil rights charges against officers based on the same events. See Koon v. U.S., 518 US 81 (1996).

4 For accounts of the case, see Lou Cannon, Official Negligence: How Rodney King and the Riots Changed Los Angeles and the LAPD (Boulder, CO: Westview, 1999), pp. 108-20, 148-73; Brenda Stevenson, The Contested Murder of Latasha Harlins: Justice, Gender, and the Origins of the LA Riots (New York: Oxford University Press, 2013). 
5 See Stevenson (2013), pp. 152-5; Cannon (1999), p. 109.

6 See Cannon (1999), p. 148. That Judge Karlin had spent her practice career in federal court is relevant because the kind of criminal cases handled and courthouse culture are very different in federal and state court. For example, federal courts handle relatively few murder cases.

7 "Great Provocation and Duress": The Judge in the Du Manslaughter Trial Explains her Reasons for Imposing Probation Rather than Prison Time, Los Angeles Times, Nov. 22, 1991 (text of sentencing remarks).

8 Mary Harris, Good Samaritan Remembers the LA Riots 20 Years Later: "I Had to Do Something," found at https://www.nbclosangeles.com/news/local/A-Good-Samarita n-Remembers-148613585.html. More details of the story are included in John Ridley's documentary, Let It Fall: Los Angeles, 1982-1992, Lincoln Square Productions (2017).

9 Los Angeles Times Staff, Deaths during the L.A. Riots, Los Angeles Times, April 25, 2012.

10 Kate Mather, LA's Uncivil War: Once-Staid Police Commission Meetings Are Regularly Upended by Protesters, Los Angeles Times, May 22, 2016; see also Kate Mather, A Traffic Stop Turns Deadly: LAPD Officer Fatally Shoots a Man in South L.A. Hours after an Emotional Police Commission Meeting, Los Angeles Times, Aug. 17, 2016.

11 Jake Halpern, The Cop: Darren Wilson Was Not Indicted for Shooting Michael Brown. Many People Question whether Justice Was Done. The New Yorker, Aug. 10, 2015 (interview with former Ferguson police officer Darren Wilson).

12 Id.

13 For an introduction to this history in 19th century South, see Leon F. Litwack, Trouble in Mind: Black Southerners in the Age of Jim Crow (New York: Knopf, 1998).

14 Tennessee statute, cited in Tennessee v. Garner, 471 U.S. 1, 4-5 (1985).

15 Michael Eric Dyson, Tears We Cannot Stop: A Sermon to White America (New York: St Martin's Press, 2017), p. 181.

16474 U.S. 1 (1985).

17 The police officer who shot Garner was also black, but this does not, by itself, demonstrate that race played no part in the shooting. Historically there were very few African-American police officers in Memphis and those officers historically had suffered systemic discrimination. For example, after nine black officers were hired in 1948 following an initiative by local black leaders, they were told only to arrest blacks and had a separate roll call from white officers, which was held in the department garage. Roll call in the department was not racially integrated until 1964. Patrol cars were integrated in 1966. Tennessee Advisory Committee to the US Comm. on Civil Rights, Civil Crisis-Civic Challenge: Police Community Relations in Memphis (1978), p. 9. The police director in Memphis said that in order to secure their place in the department, "the black officers tried to out red-neck the white officers." Brief for AppelleeRespondent, fn. 52.

18 See Litwack (1998); Equal Justice Initiative, Lynching in America: Confronting the Legacy of Racial Terror, https://eji.org/reports/lynching-in-america.

19 She continued: "No one can view the death of an unarmed and apparently nonviolent 15-year-old without sorrow, much less disapproval." Id. at 29. 
20 Id. at 29.

21 An autopsy revealed that the teenage Garner had been drinking. He may have feared not only legal consequences but parental discipline if he was caught. Brief for Appellee-Respondent, fn. 5.

22 Brief for Appellee-Respondent (Cleamtree Garner), p. 17, citing Record at 326, 345.

23 Brief for Appellee-Respondent, p. 20.

24 James F. Fyfe, Blind Justice: Police Shootings in Memphis, 73 J. Crim. Law \& Criminol. 707, 718 (1982).

25 Fyfe (1982), pp. 718-20.

26 Brief for Appellee-Respondent, fn. 39.

27 Brief for Appellee-Respondent, pp. 15-16.

28 See particularly, the new National Memorial for Peace and Justice in Montgomery, Alabama; Campbell Robertson, A Lynching Memorial Is Opening. The Country Has Never Seen Anything Like It, The New York Times, April 15, 2018.

29 For evidence of dangers to police from widespread gun ownership, see David I. Swedler, et al., Firearm Prevalence and Homicides of Law Enforcement Officers in the United States, 105 Am. J. Public Health 2042 (2015) (finding correlation between rates of police officers killed in a state and rates of state firearm ownership). For a correlation between state laws regulating guns and fatal police shootings of civilians, see A. Kivisto, B. Ray \& P. Phalen, Firearm Legislation and Fatal Police Shootings in the United States, Am. J. Pub. Health, May 18, 2017.

30 Meet the Press, Nov. 23, 2014.

31 Ta-Nehisi Coates, Between the World and Me (New York: Spiegel \& Grau, 2015), pp. $110-11$.

32 See generally, Heather Mac Donald, The War on Cops: How the New Attack on Law and Order Makes Everyone Less Safe (New York: Encounter, 2016), pp. 119-47.

33 Matthew Cella and Alan Neuhauser, Race and Homicide in America, by the Numbers, U.S. News \& World Report, Sept. 29, 2016. In 2011, African-Americans were 13 percent of the population but were 50 percent of all homicide victims. Violence Policy Center, Black Homicide Victimization in the United States: An Analysis of 2011 Homicide Data, Jan. 2014, www.vpc.org.

34 Cella \& Neuhauser (2016).

35 FBI, Crime in the U.S., 2015 found at https://uci.fbi.gov.

36 For the strong connection between poverty, crime and punishment, see Bruce Western, Punishment and Inequality in America (New York: Russell Sage, 2006).

37 Geoffrey Canada, Fist Stick Knife Gun: A Personal History of Violence in America (Boston: Beacon, 1995).

38 For evidence of this in New York City, see Sarah Riley, Barry Paddock Rocco Parascandola \& Rich Schapiro, Tale of Two Cities: Even as Murders Hit Record Low in NYC, a Mountain of Cases Languishes in Outer Boroughs as Cops Focus More Manpower on Manhattan Cases, N.Y. Daily News, Jan. 5, 2014. For low clearance rates in minority communities in Los Angeles, see Jill Leovy, Ghettoside: A True Story of Murder in America (New York: Spiegel \& Grau, 2015), pp. 48-9; Catherine Lee, The Value of Life in Death: Multiple Regression and Event History Analyses of Homicide Clearance in Los Angeles County, 33 J. Crim. Just. 527 (2005). 
39 E.g., Leovy (2016), pp. 6, 69; Jim Newton, Change in Black and White in L.A., Los Angeles Times, March 6, 2011 (citing old LAPD code of NHI-no human involvedused by patrol officers to refer to domestic violence in black families).

40 Social scientists have described certain neighborhoods as "poverty traps" in which violence is common and police are widely distrusted, with devastating community effects. See Jeffrey Fagan \& Daniel Richman, Understanding Recent Spikes and Longer Trends in American Murders, 117 Col. L. Rev. 1, 17 (2017). This seems to occur in some Chicago neighborhoods. See David Heinzmann, As Chicago Killings Surge, the Unsolved Cases Pile up, Chicago Tribune, Sept. 9, 2016 (reporting a homicide clearance rate of 30 percent in Chicago, far lower than other comparable cities; distrust in police, which leads to witness noncooperation, and understaffing of detective units seen as causes). For the effects of failures of policing in minority communities, see Alexandra Natapoff, Underenforcement, 75 Ford. L. Rev.1715, 1722-27 (2006).

41 Leovy (2015), p. 253.

42 The text may be found at historyplace.com/speeches/douglass.htm. For a 20th century critique from a similar perspective, see the address given by Justice Thurgood Marshall, Reflections on the Bicentennial of the United States Constitution, May 6, 1987, published in the Harvard Law Review, 101 Harv. L. Rev. 1 (1987).

43 See Richard Rothstein, The Color of Law: The Forgotten History of How Our Government Segregated America (New York: Liveright, 2017).

44 Abraham Lincoln, First Inaugural Address. It may be found online at http://avalon.law. yale.edu/19th_century/lincoln1.asp.

45 James Baldwin, In Search of a Majority, in Nobody Knows My Name (New York: Vintage, 1989, 1961), p. 136.

46 See Eugene D. Genovese, Roll, Jordan, Roll: The World the Slaves Made (New York: Pantheon, 1976); The World the Slaveholders Made: Two Essays in Interpretation (Hanover, NH: University Press of New England, 1988).

47 As James Baldwin wrote: "my own experience proves to me that the connection between American whites and blacks is far deeper and more passionate than any of us like to think." Baldwin (1961), Introduction, p. xiii. 


\section{1}

\section{LIVING A LARGER JUSTICE}

Coming now to the end of this work on criminal violence and criminal justice in America, a reform-minded reader might expect to find a set of rules and policy prescriptions. So many problems have been detailed and so many calls to change have been issued, that a reader might anticipate a prospectus for new laws and institutional structures, new resources and, very likely, a transformed politics at this, the book's close. That's usually the payoff from works on contemporary social problems.

But the truth is that we do not lack for good policy ideas in criminal justice. We do not lack for resources, either-if we are willing to engage in some resource redistribution. What we lack is the will to change.

Many Americans do not see the need for criminal justice reform because they do not see the many victims of wrongful violence and their pain. Nor do they see the many people treated unjustly by the criminal justice system today. Both groups are numerous, and quite visible - if we care to see them. We readily recognize victims of violence in headline cases; others, who comprise the vast majority of victims, not so much.

Most Americans do not appreciate how much past violence affects the present lives of those they know. I think of participants in church groups I have led on the topic of violence, and the stories of childhood abuse, sexual and otherwise, and domestic violence, that they have told. These have been mostly white, middle-class older women. They would not normally speak of these past events, because who wants to hear about them? And telling may feel shameful. It is usually painful. I think of women, young and old, who felt personally violated by the election of a man who had boasted of being able to grab women between the legs and get away 
with it. A friend blurted out to me in conversation weeks after the election that she was nearly suicidal at his triumph, because he reminded her so much of her abusive first husband. The past living on in the present.

As for system injustices, to many these are mostly abstract propositions, hard to make sense of. When undeniable injustices occur, such as the exoneration of a long-term prisoner, this is seen as exceptional. The casual, ordinary unfairness of a bureaucratic system that largely assumes the guilt of those caught up in its nets goes unseen. Most do not know about the men I meet in jail, some never arrested before, some arrested many times before, who are treated in ways that I never would be, because I do not look like the usual suspect, do not have priors, and because I have money and connections. If I ever broke the law, I could appeal for mercy and expect to be heard; they mostly cannot.

In this final chapter, I turn from big justice questions to small, from the macro to the micro. I turn from justice seen from a great height, to justice at ground level. I suggest how a commitment to a greater justice might change how we live, whether we are criminal justice professionals or just regular citizens.

\section{Advice for Doing Justice}

Philosophers of the classical world placed character at the center of their study of morals and ethics. Rather than seeking general rules for right and wrong conduct, they explored the virtues and vices - the character traits - that inspire right and wrong actions. Despite my frequent criticism of character-based judgment (all that good guys versus bad guys stuff), this approach is very apt for addressing what it takes for an individual to do justice.

Begging the reader's indulgence, I will here play teacher (or preacher), and address directly those who may want to do criminal justice work and then everyone else who must make justice calls, which really does mean everyone else.

\section{To the Criminal Justice Professional}

No matter what your job, criminal justice work will test your character. It's hard to figure out at the beginning what to do and it's hard to do, day after day, after you have figured it out. I see four character traits as essential to doing justice: courage, humility, faith in justice and care for the hurt.

\section{Courage}

To do well and to do right in criminal justice takes courage. Occasionally this means physical courage, especially for those on the front lines of law enforcement. 
Peace officers must be willing to take physical risks to protect the public. They must also make sound judgments in the face of danger. The willingness to risk life or limb does not have much value unless one can also think clearly in the face of danger.

But in today's criminal justice world, moral courage is more often tested than physical courage. This means being willing to follow your best judgment, even when that may open you to criticism by colleagues, superiors and the public. I am not talking here about disobeying a direct order or violating the law. I am speaking about the courage to make the right decision when the decision lies within your discretion. Can you make what you feel is the right call, even when it's not the safe call for your career? This includes making tough calls yourself rather than just passing them on to others.

You will need social courage to admit wrong when you have done wrong. And you will mess up. You will do wrong. It's a question of when, not if. When it happens, will you have the courage to admit the wrong to yourself and to the world, or will you deny wrongdoing in hopes that you will not be called out on it?

Finally you will need courage to engage the world's pain. The civil rights lawyer Bryan Stevenson talks about the need to get "proximate" to people in trouble. He says that you have to get close to people suffering to understand what justice requires. Imagine being a patrol officer who encounters a woman recently assaulted who is also homeless and mentally ill. She is difficult to look at, she smells, and she is ornery, volatile. The question is whether you as a police officer will take the time to hear her story, not just in words but in spirit.

But this is not just about police officers. Perhaps you have chosen work as a criminal defense attorney and now must meet a new client in lockup. Even though pressed for time, will you listen to this man not just for the basic facts of the case but hear him on his life situation, understanding that he is terrified and cannot trust you until he sees you care for him as a person? Will you the prosecutor keep the traumatized victim witness at a distance, the better to manage the relationship, or will you allow yourself to feel a little of her pain? Will you understand that you may have to explain important legal points to her, again and again, because when triggered, trauma severely burdens the mind?

Getting close to the hurt takes emotional courage because once you get close you will feel echoes of their pain inside you. And when you go on your way, some of that person's pain will come with you.

\section{Humility}

Despite what we see in the news and thrill to in crime dramas, justice does not often require heroes. There is a time and place for heroes of course. We love 
hearing about the lone brave individual, who against daunting odds, through sacrifice and courage, brings down evildoers. And yet aspiring to the heroic in justice work should be discouraged. The problem is not with heroic action, but with heroic aspiration. The problem is with believing that you can, or must make justice happen by yourself.

In police work, pursuing hero status can physically endanger others. The officer who charges into a hazardous situation without backup or a considered plan can put many at risk. More often in justice work, the danger of taking on too much is more moral than physical. (Note the similarity here to courage.) We need humility to recognize individual limits in power and judgment.

Many go into criminal justice with a determination to make a difference. And this can be a worthy goal, if combined with the understanding that success always depends on others. If the professional decides that she, personally, must make the difference, then she takes on an impossible burden, though. Sooner or later the hero-professional's ambition will lead to a disregard for legal and moral checks on the use of power, or to despair.

I think of those in law enforcement who believe that they represent the line dividing the good from the bad in society, and that they must everywhere and always, protect the good and punish the bad. Taking on the moral—and physicalweight of the moral world leads to frustration when the professional sees all the obstacles put in his way, political, legal and bureaucratic. A young defense attorney determined to right the social wrongs of the world by zealous representation of the marginal will run into similar obstacles. Humility in justice work means that you judge yourself not on outcomes, which you cannot control, but on the effort made, which you can.

And finally you will need humility to protect against the temptations of moral arrogance. Especially if you are a police officer, prosecutor or judge, you may come to see it as your job not just to assess guilt or innocence on criminal charges, but to judge the value of other people's lives. To decide who is fundamentally criminal, and who is not. To separate the good from the bad. I do not have to say (having said it so often before) why this is a mistake. You need moral humility to understand what you can and cannot judge, meaning why it is so important to judge the rightness and wrongness of actions rather than lives.

\section{Faith in Justice}

Do you believe in justice, really? Will you believe in justice and not just in doing your job after three years, five years, ten years in the field, when so many around you settle for less? When they settle for much less? Faith in justice shows in the 
perseverance and determination of the best. Its lack shows in the weariness and frustration of those who have burned out.

Faith in justice means a belief that doing justice is possible. It requires faith in human good and in human systems. This can be hard to come by when every day reminds you of the human capacity for evil and the mindlessness of bureaucratic systems.

The great enemy of faith in justice is the System. The System has its own rules and demands, often unwritten but still powerful. These may appear as the accepted norms of the section, department, courtroom, or courthouse where you work. Just to let you know, that's not how we do things here. This is what everybody does. Just do it that way and you won't have any trouble. Warnings like these given to newcomers need to be taken seriously, because system rules can never be blithely ignored. Every day, the system casually crushes clueless individuals who are ignorant or disrespectful of its unwritten rules. But system rules are not justice rules. System rules are about efficiency and conflict avoidance and individual and group self-protection. Keeping faith in justice means keeping your own values and not taking system rules to heart. You need your own internal rules for when to go along with the system and when to refuse. Sometimes the defense attorney must make the pretrial motion in a misdemeanor case that no one in the courthouse ever does and that the judge thinks is a waste of her time, but may be critical to a just outcome in the case. Sometimes the prosecutor must object to a routine request for a continuance that is normally agreed to as a matter of course, because the victim simply cannot wait any longer for legal resolution. Sometimes the police officer must refuse to cover for a partner or colleague who may have broken the rules.

Faith in justice must be a personal faith; it cannot depend on the opinion of others. It cannot depend on case results. It is grown and sustained by relationships with a handful of people whose character you trust. Their support will keep you going in the difficult times, and there will be plenty of these.

\section{Care for the Hurt}

A psychologist and priest that I know in South Los Angeles, Stan Bosch, regularly brings together police officers and gang intervention workers to improve relations between them. Each group plays an important role in fighting gang violence in one of the most violent parts of the city. Each has reasons to distrust the other. (The gang intervention workers are mostly former gang members.) Bosch begins these meetings with a question: "What brought you to this work?" The answers usually involve concern for the hurt. The original concern might be for victims of 
crime or for those growing up in the neighborhood, but caring for others is common to all.

In criminal justice work, the challenge is to expand and not contract your circle of care. The adversarial system pulls powerfully in the opposite direction, toward a smaller $u s$ and a larger them. A greater justice will require police officers to see the humanity of gang members and at risk youth, despite the havoc that some kids wreak on the community; it will require former gang members who have suffered and seen others suffer greatly at the hands of police, to see the humanity of men and women in blue.

It's hard to have a big heart in criminal justice work, for it will be regularly broken. People will disappoint you. Institutions will disappoint you. The law will let you down. Your trust will be betrayed. And yet there is no substitute for caring. You might be able to do your job without it, you may be able to follow the rules, written and unwritten, without it, but I do not believe you can do justice for long without it.

\section{To Everyone Else}

People who work in criminal justice naturally think that they know a lot about it. Certainly they believe that they have special knowledge and skills that members of the public do not. Police officers believe this and so do corrections officers. Prosecutors and criminal defense attorneys believe this, even though their understandings often take them to opposite conclusions. Judges in the criminal courtroom believe this and so do professors of criminal law and professors of criminal justice. And why not? Given all the training and education each has, given all their experience, surely these folks have a solid claim to expertise in criminal justice. Each knows important things that the public does not. As a result, each will seek to persuade the public that their knowledge and their experience should guide. Each will want to tell the less knowledgeable members of the public what to think and believe.

And yet there are no experts on justice. Justice is too personal for that. There are experts on criminal law, on policing and adjudication, on patterns of crime and the effects of punishment, on interactions between mental health and substance abuse and crime and much more. Moral and political philosophers may have thought more deeply and broadly than the rest of us about principles of justice. But doing justice depends on our personal — and collective - vision of right and wrong. While experts may provide important data and insights, the final conception of justice in a democracy is the work of ordinary citizens. And so I offer some words now, not for criminal justice professionals, but for everyone else. 


\section{Emotional Self-Awareness: Interrogate the Gut}

Each of us has our own sense of right and wrong, of justice. When asked to respond to potential wrongdoing we usually begin with intuition, meaning a gut feeling. This initial sense of rightness or wrongness is emotional. Our feelings about justice need to be taken seriously, but also to be interrogated. Like every other human faculty, our emotions are fallible. They may arise from faulty data or personal needs; they may come from personal experiences quite different from the situation judged. This means we need to question our justice feelings, regardless of their strength. Is this fear that I feel, is this anger-even rage-that I experience, justified? Have I looked closely enough at the facts to see if there is anything that might contradict my initial assessment? Have I considered what in my background or makeup might contribute to this emotional response? How do I see myself in all this? Am I willing to reconsider my feelings, or am I determined to hold fast to my first, emotional, judgment?

Police are often criticized for jumping to conclusions in their investigations and then refusing to consider alternative explanations. If the public must make justice decisions - and in a democracy it must, frequently - then members of the public must also avoid premature conclusions and refusals to reconsider.

\section{Proximity: Stepping Closer to the Other}

We all believe that our personal experiences reveal larger truths about Life. What we have felt and seen and heard in our lives, the conclusions that we have drawn from our experiences, these must apply to everyone. Let me tell you about what I learned growing up. Or, this is what I believe, based on everything I've been through. We assume that our experience reveals the principles by which the whole world works, or should work. In the process it's easy to miss the limitations of our personal experience.

In fact, even if we occupy the same proximate space, oftentimes we live in different worlds. Differences in age and class and race and gender, of region and national origin-lead to different understandings of the human condition. These differences need to be respected and not dismissed or derided. Only by respecting differences in experience can we see others as they are and not as who we imagine them to be, or how we think they should be.

Recognizing difference should not prevent belonging, however. Given that belonging is a central goal of a greater justice, being critical to both violence prevention and healing from its wounds, we need to think hard about our own views about who is in and who is out. Who do you feel belongs in your community? 
Who does not? Can you defend those exclusions? Do you understand the consequences of those exclusions? Can you find a way to welcome those most prone to exclusion and self-isolation, who live on the margins? The only way I know to manage this is gradually: take one step closer, and then another. We need to get steadily more proximate.

Just as criminal justice professionals must get close to the hurt to do justice, so must we as citizens. Many will resist. I have my own life to lead, thank you very much. I'm not putting myself or loved ones at risk. I have other priorities in work and life. To which I say fine-I do not ask that much. Just consider taking one step closer to the other, in mind or spirit or body. Wherever you find yourself, try to take one step closer to those who seem most foreign to you, whose hurt is important to justice. Pay attention to news items that concern them. Watch the television shows that tell their stories. Walk in a neighborhood different than your own, eat at a restaurant with a different clientele. In line for an event, for a plane, for a bus, strike up a conversation with the sort of person you would normally avoid. One step at a time. You will find that you feel less isolated. You will start to feel that you belong to a bigger community. These moves may not seem justice-related, but changing who we connect with can change how we judge right and wrong. As we have seen, time and again.

\section{Observations from Personal Experience: Justice Lived Small}

I always thought that somewhere along the line I would win a big case or write a big book, or somehow do Something that would make me Somebody. It never happened, though. I did a lot of somethings, and I was somebody to the people I knew, but I never did anything to merit capitalization. I never did Something and never became Somebody. The world never took much notice of me.

Here's the surprise. I doubt I would have found my way to the justice work I do now, if my grander ambitions had been fulfilled. I would not have discovered the rewards of justice work on a very small scale. I would have missed a lot.

I make my living at Loyola Law School, which is found just to the southwest of downtown Los Angeles. I have been teaching there for just about forever, primarily courses in the criminal area. My job is to prepare young people for the practice of law. In the classroom I try to present the law, including its hardest aspects, in the best way for students to learn. My job is also to assess, to give out grades. Students devote considerable energy to discerning what will be on the final exam and how I grade, preoccupations which can be tedious but which I must respect, because grades can directly affect career prospects. While in class I frequently ask students about the justice of the law we study, these discussions can never go too long or 
too deep; the priority is learning law. Which makes me doubt sometimes whether teaching law has much to do with justice as opposed to professional training. Of course a teacher, like a parent, never really knows when his words will matter. A brief comment, an off-hand remark, can change a life. I also think of those times when I very consciously put justice questions front and center in class.

When I teach the law of rape, focusing on assaults by acquaintances and address sex and gender, miscommunication and trauma, or when I give a talk on the anniversary of 9-11, which I do most years, considering it as our most significant collective experience of wrongful violence, I am often met with that special silence that signals close listening.

The same has occurred when an event in the news shakes my students' faith in justice and right. The acquittal of O.J. Simpson on murder charges in October, 1995, which we watched live in my first year Criminal Law class or a class after the horrors of the Las Vegas shooting in 2017. At these times I knew it was my job to keep public faith in justice. This was not because I knew that the truth would always emerge, or the rule of law would always triumph, or the right decision would be made in the end. That's Hollywood's version of justice. That's not the reality of this broken world.

In these moments of crisis I have urged my students to keep faith with justice because without justice we lose the difference between public right and wrong. We cannot even talk about the difference. It's when our normally (we think) reliable systems go wrong that we need people, including lawyers, who have strong justice values. Such moments are also an invaluable opportunity for many of us to see justice from a different perspective. It's when those of us who have a modicum of money and education and security see the system go wrong that we can understand, a little better, the experience of those who see the system go wrong all the time.

Becoming a teacher was a surprise for me. I never considered teaching as a career, indeed I had rejected it as a possibility until I fell quite in love with law in law school. So strong was its intellectual pull that after a few years of law practice I circled back to join the legal academy, where I have remained ever since. That was not the last surprise of my professional life, however. Years later, a call to ministry snuck up on me with even greater stealth.

I was in my mid-40s, my father had recently died, and I felt an emptiness inside that needed filling. To my considerable surprise, the answer seemed to involve the church. After a period of what we in the church call discernment, I decided I would try to do part-time ministry with people in criminal justice. Some who heard of my plans assumed that I would work with the incarcerated, but I thought not. I had done some ministry with youth in juvenile hall, and it hadn't gone all 
that well. My hope was to minister to criminal justice professionals-lawyers and judges, perhaps police - and also, especially, to victims of violent crime. These were the people I thought needed spiritual care most. And it best fit my prosecutorial background and my scholarly writing about responsibility for crimes of violence. I have in fact done this kind of ministry when I have had the chance, but mostly, today, I do ministry in jail, with the incarcerated. Another of life's surprises.

So it is that the other place I do justice work is in the Twin Towers Correctional Facility. The Twin Towers are located on the northwest edge of LA's central city.

In some ways jail is an awful place to attempt the greater justice that I have described in this book. The American jail is an institution of the criminal law. It exists to secure bodies for the law's determination of individual blame and for punishment following conviction. (In California, both persons convicted of misdemeanors and those convicted of nonviolent felonies serve their time in county jail.) It's a place where inmates are categorized by current charge and past record, gang affiliations and mental health status. Not a lot of seeing the unique individual here.

It's a place designed to hold bad guys. Some may not turn out to be so bad, but society's presumption of their badness is very strong. Being in jail represents a decision by society that, at least for a time, this man does not belong among us. As a result, it's a place where hope is easily lost, and humanity. Persons become bodies with booking numbers. They must be housed and fed and moved and managed, but not respected as unique individuals.

A county jail collects some of the most broken souls in the community: the homeless and the mad (in all senses), the dangerous and the frail. It houses people who are in deep trouble and who have caused great trouble. Although there are educational and other programs in jail, it is a place designed primarily for safe storage of persons and not their rehabilitation.

Given all this, jail would not seem a good place to attempt healing from past violence, or any kind of reconciliation. If we want to increase the belonging needed for a larger justice, this place of not-belonging would seem a poor place to begin. And yet jail can sometimes be an excellent place to seek a larger justice, though on a very small scale.

Jail can provide a place for respite and reconsideration. It's not uncommon for men to tell me that their lives were saved by being locked up. They explain that their drug use or criminal activities (or both) were likely to get them killed and they were not likely to stop on their own. Their life was out of control. Getting locked up can provide a chance to turn away from years of addiction, or to wonder at the rage that spilled out against a wife or girlfriend. In jail I meet men who feel torrents of shame and guilt for letting down parents, or children. Missed funerals 
and birthdays cause deep pain. Being locked up can provide a powerful motivation for change.

I don't want to exaggerate jail's rehabilitative possibilities, though. In jail, survival comes first, getting out is most inmates' main priority, and many have been in and out of lockup so often in their lives that the chances of them making this time their last, seem small. My point is just that jail's very awfulness can open the way to change.

My ministry takes two basic forms: individual visits in the IRC, and Sunday services in Tower Two.

Often on a Thursday or Friday afternoon I go to the Inmate Reception Center (the IRC) in the Twin Towers, where male arrestees are processed before entering the county jail population. I talk to some of the men who wait there.

If there were such a thing as Brutalist interior architecture, that would be the IRC: bright fluorescent lights, polished cement floors, painted cinderblock walls and rows of blue plastic chairs bolted in place. In some ways it is reminiscent of a big city Department of Motor Vehicles, with people waiting long hours to be called up to speak with a clerk who takes information from behind a computer screen, and then sends the supplicant back to wait to be called for the next station.

There are no clocks in the place, which may be a mercy, for the waiting here can be nearly endless. The deputies aim to process men through within a 16-hour window, but it can take a lot longer. Inmates often ask me the time and then may ask if that is day or night. Men are in the IRC on all manner of charges. It may be on a years-old warrant for failing to appear in court, a new arrest for drinking a beer in public, for probation or parole violations, or for felonies ranging from grand theft to murder. Some men wait patiently, some angrily; some are in great pain for this is also where inmates are taken if they have serious medical conditions in jail. In one of the main waiting areas there are large screen televisions mounted on the wall that incongruously (to me) show action thrillers full of guns, explosions and blood.

I visit with the waiting men, talking with those who are willing to converse. We talk and then sometimes pray.

There is an L-shaped row of cushioned brown seats overlooked by a raised podium where deputies and custody assistants work at computers. The men on the brown seats are handcuffed and chained. They wear suicide gowns, a strange quilted garment without sleeves that wraps the man from shoulder to the knees. The men are there because they have shown signs of major mental illness or being at risk of suicide.

I remember speaking with a man I'll call $\mathrm{R}$. Although we were strangers, we soon entered that quiet space where the most important things can be spoken. 
Mostly I listened. R. told me he was confused about why he was there. I'm not sure if he was speaking of being in jail or being handcuffed on the brown seats. He shared with me some of the events in his life that had knocked him off track. He told of an older brother's murder by gun. He actually saw his brother die. For years after, the event has echoed in his head. A little later in the conversation, almost in passing, he mentioned that he was molested at elementary school, and how that changed the life of his brother as well.

I thought about this and then made a suggestion. I said something like this: "Seems to me there are in your life two big losses that need to be mourned: the loss of your brother, and also the loss of the little boy who was molested. That boy was taken away and cannot come back."

My words had an immediate effect. Something in him shifted, settled. His face and bearing lightened. He smiled, almost with joy. Yes, that's right. That's right, he said. His eyes seemed clearer and he seemed more sure, as if he recognized where he was, as if he had been found, finally. His pain and experience had been recognized by another, allowing him to see it better too.

Healing from violence can work this way, in small, quiet moments, undramatic; also uncertain, because there's no telling what comes next. By itself, one conversation changes little. Where there is a sharing of pain and vulnerability, though, a bond can be stated that demonstrates the possibility of belonging in a most unlikely place and situation. Hope appears, as if from nowhere. Maybe things can change. Maybe the past does not have to rule the present, as it has for so long. We would not normally call this justice, but it feels like part of a larger justice to me.

And now another snapshot of jail work: the cell extraction.

We should never underestimate the messiness, even the ugliness of justice work. It requires entering situations, places and lives where chaos has taken hold, where rage, confusion and despair swirl.

I was in the IRC, waiting to talk to the head deputy about an inmate I had just seen, when I was told that I had a phone call. The voice on the phone told me to come to 151. For a cell extraction.

Like most institutions, jails work primarily by cooperation. Inmates mostly follow directions. Life inside goes better that way. It's when an inmate refuses to cooperate that the coercive nature of the place is most clearly revealed, as, for example, when an inmate refuses to leave his cell when asked. The Los Angeles Sheriff's Department has a protocol for how to handle these situations, in which staff and officers attempt to coax the inmate to leave on his own. Chaplains are now part of this process. The hope is to minimize the use of force which can injure inmates and deputies alike. Also to minimize lawsuits against the County. 
The call to 151 took me to one of the facility's High Observation Housing units. In these units, which are reserved for the most at risk mentally ill, prisoners are housed in single cells and closely monitored. I had been in units like 151 before, but not often, and I had a hard time staying present. To put this more plainly, I had a hard time not freaking out. One man stood at his cell door and pounded it with his whole body, producing a terrible thunderous sound in the cavernous, hardsurfaced space. Another hurled angry, cursing, accusatory shouts at the unit's visitors from behind his closed door.

I was directed to a second-tier cell in E-pod. I waited on the stairs while a mental health clinician finished talking to the inmate. I could not hear what she said, but she did not succeed in what she was after. She soon came down the stairs, fast, avoiding eye contact.

I was led to the cell and outside its door we performed a legal ritual with a video camera in which all gathered established names, titles, time and situation for the record. Then commenced a series of efforts to encourage the young man who sat at the far end of his bed to cooperate in being moved to the cell next door. The need for the move was undeniable.

The young man, who I will call S., was in his late teens or very early 20 s. He was naked, with his suicide gown draped across his waist. He looked exceptionally fit, with an athlete's gracefully proportioned, well-muscled body. But all was not well with him. He had thrown feces all over the front glass of his door. Excrement was caked on top of his toilet. The cell was strewn with remnants of food. When the tray slot in the door was opened, the smell that emerged was awful. It was a smell of waste and decay of many different varieties and almost colors.

The group that assembled to try to talk him out was a varied one. We had a lieutenant, two sergeants, and a deputy sheriff; three male and one female; two white, one African-American and one Latino. S. was African-American. Each had his or her own approach to the task, from inducements of hot food to concerns for S.'s physical safety and dignity. Each spoke sensibly and respectfully. S. seemed to hear what was said, but he did not move. He never spoke a word. He never made a sound. He looked at us with frightened eyes, that were like bright spots at the end of a dark tunnel. He was only 6 to 8 feet away, but it seemed much further, because he was in a very different place than we were.

When it was my turn to try I noticed that there were large pencil drawings of superheroes on the cell walls. I recognized Wonder Woman above where he sat. I asked S. if he had done these, and he nodded, the first response I had seen him make. I told him they were really nice and he seemed to appreciate that. I said that I had a pencil, and showed him a short yellow golf pencil (the only kind that inmates are allowed), which caught his interest. I asked the 
deputy beside me if I could give it to him. I was told: if he comes out. And so I made that offer, but did not get a response.

It seemed as if the force team would soon be called. Apparently they were doing a cell extraction in another part of the jail. I imagined them suited up in their riot gear-helmets and heavy vests, with shields and pepper spray at the ready. Most of the officers went down the stairs. I remained, along with a young male deputy.

"Do you still have that pencil?" the deputy asked me. I said yes and gave it to him. Then I stood aside, out of view of the cell door, thinking that might help his efforts.

The deputy, who seemed to have a prior relationship with S., talked to him in a calm, quiet, offhand manner. He did not urge, argue or cajole but just suggested what could happen with a move. He mentioned that the chaplain was still here. He offered the pencil and new opportunities for drawing. Within a few minutes he had gotten S. to the door and to turn around so he could be cuffed through the tray slot. And he was moved. It was over.

I told the deputy, well done. Really, well done. He perhaps nodded, but in general the deputies are not much for taking praise from chaplains. We're not in the chain of command and what do we know, really about their work? I hope he took it to heart, though. There was a simple grace to his words and actions, even how he got S. to maneuver for the final cuffing, that conveyed regard.

This is how justice on the ground can be. No great triumphs, no landmark decisions or dramatic third act turnarounds, just a bad situation not made worse, that was, instead, made a little better. It was a moment of peace in a place of madness.

Once or twice a month I lead a Sunday afternoon church service in Tower Two. It's a challenging place to do a service, because in addition to all of the other distractions of the jail setting, the men who come to services all wear the yellow shirts indicating that they are receiving mental health treatment. I never know their state of mind as we begin.

We do the service in an open space in front of the ABC pods, three of the six separate residential units on the floor. Framed with high Plexiglas walls, the pods appear from the outside like human aquariums in which the inmates may be viewed in their jumpsuits or just boxers and t-shirts, milling around, talking, playing cards, exercising, watching the big screen TV high up on a wall, or trying to sleep in bunks with sheets pulled over their heads. There are many audio distractions: announcements that blare suddenly from the public address system for inmates who have visitors. Trustees and other inmates may move in and out of the unit; the murmur of a distant television or a one-sided argument between a deputy and inmate may provide aural background. 
During the service I may get random questions that the questioner suddenly thinks that I might have the answer to. Sometimes one or more of the men will get up in the middle of the service and, without explanation, walk away. I never know why. Those who stay, though, often become increasingly engaged. Occasionally I will sing a hymn a cappella near the end of the service. I like the sound of the human voice in the hard space and I hope to convey care in a way that spoken words cannot. On occasion I will try to lead them in collective song. When they are willing to try, it is wonderful, even if not very tuneful.

By the time we finish, I feel as if I know the men who face me seated in the molded plastic chairs, just a little. They have come to know me, a little. If there is time, I may invite anyone who wants to come up for a personal prayer. The prayers are often for parents, children, partners; for life change and of course for freedom. Tears appear with some frequency, though they are quickly wiped away.

I often struggle with doubt about my jail work. Am I making any difference? Being ignorant of their backgrounds and what they are charged with, how can I know what's really going on with the men I see? (Because of my background as a crime reporter and a prosecutor, I likely worry about this more than most jail chaplains.) I am often quite clumsy in my interactions with the men. This is not false modesty; anyone can tell when a social exchange goes wrong and that happens to me with some frequency in jail. I say the wrong thing, ask the wrong question, let my own issues get in the way.

Sometimes I leave jail feeling that I have been part of something truly extraordinary and wonderful. Sometimes I leave mostly with doubts. Pretty much like any other challenging job.

What is hardest for me to convey about jail ministry, and I think this applies to any greater justice work, is its mutuality. I go to jail as much for me as for them. I think that justice work has to be at least partly self-interested to succeed. Benevolent motives, such as the sense that one needs to give back, or the pity that one may feel for another person's suffering, or guilt about social and personal inequities, these will not be sufficient to sustain the effort in the long run. Only when we feel that somehow we are in this together, appearances to the contrary notwithstanding, will we find the sustained energy needed for the work.

In my justice work, whether at school or in jail, I don't know that I accomplish much. I just don't know. Working at ground level, one only gets glimpses of what might be success, or failure. What I try to hold onto are the moments of mutual concern and true seeing that I share with people who are mostly strangers to me, and I to them. I trust the potential of these moments to shift where we standwhere we stand-in the world. 


\section{The American Dream for Justice}

For the last 30 years I have walked around the Pico-Union neighborhood where my school is located, morning and afternoon. I have seen and felt how the city of LA has changed over that time. Violent crime was high through the mid-1990s, but steady declines since then have changed the look and feel of the city. Gangs which before ravaged the locale at night have retreated and there is less graffiti on buildings and signs. Residential and commercial developments have come back. There are more people out walking. Also more homeless. Tents and mattresses and trash proliferate under the underpasses and along the freeway on- and off-ramps.

The highlight of my walks in recent years has been the neighborhood children going to and from school: the pre-K and kindergartners who attend the Olympic Primary Center, the elementary and middle schoolers of the Immaculate Conception Parish School and the students of Tenth Street Elementary School. Except for the middle schoolers, the children usually travel in family clusters. Often a mom pushes a stroller containing the family's youngest, and older siblings hold her hand or grasp the stroller bar so that they walk along physically connected.

Many of the mothers and fathers of these children fled civil wars and criminal violence in Honduras and Nicaragua and El Salvador to come to California. For them America was not just a place of economic opportunity but a place of peace. In their flight from violence, these immigrants from foreign lands repeated the pattern of the Great Migration of African-Americans, who in the 20th century left the South for the North and West to escape racial violence and oppression.

The American dream has always been about justice as well as individual freedom. Today the rule of law is as great a draw for many immigrants as economic opportunity. The idea that wrongdoers might be held accountable by law, in contrast to the impunity that they enjoy in many nations from which immigrants hail, is a wonderful gift for the next generation.

In the last 20 years, the majority in Southern California has changed its attitude towards those who have immigrated from nations south of our border. In the early 1990s, Gov. Pete Wilson urged the passage of Proposition 187, a harsh antiimmigration measure that won wide public approval, with television ads depicting hordes of people running across the border, under the heading of "they keep coming." The punitive sentencing laws detailed in Chapter 5 were inspired in part by fears of violence by illegal immigrants. Today, however, city and state leaders champion sanctuary for undocumented residents against newly aggressive deportation efforts undertaken by the Trump administration.

What changed? Perhaps most important, violent crime significantly declined. Gangs became weaker. The economy has improved. Policing has improved. The pace of 
illegal immigration, particularly from Mexico, has greatly diminished. In the passage of time there have been many important demographic changes in the state's population, making it younger and more diverse. But the key change is this. In the eyes of the majority, Hispanic immigrants, including the undocumented and their families, have become part of our community. They have become us.

The children setting off to school wearing their big, brightly colored backpacks and coming home in the afternoon, munching a just-purchased treat, seem wonderfully, indeed almost unimaginably, removed from the violence that their parents fled. In this image of LA today, I see the nation that we can have, if we wish. But we will have to fight for it.

Looming over this vision is a figure and a movement that I have avoided considering so far, not wanting my argument to be tied to a particular, and particularly divisive, time in our nation's political life. As I write this, in the summer of 2018, the elected leader of the United States, the President, is someone passionately committed to good guys versus bad guys thinking in criminal justice. And somehow the good guys always seem to be white and the bad guys people of color. He has been recorded admitting to, and laughing about, acts of sexual violence. He uses and celebrates personalized morality in all manner of public policy decisions. He frequently urges violence, both emotional and physical, as a way to resolve conflicts. His administration used child separation to deter asylum seekers, doing violence to immigrant families, until widespread outrage forced a change in policy. His administration has rejected asylum claims based on domestic violence and gang violence.

Many Americans support the President today. This means that many reject the vision of justice I have drawn, not just in this chapter but throughout.

Although everyone says they are for it, justice is and will always be a contested ideal. We will always argue about its meaning. Sometimes this will lead to serious fights. Part of our discussions and part of our fights will be over what we imagine justice to be. 


\section{INDEX}

acceptance: loss from violence, 229-30; offender's humanity, 230

accompaniment 224-26

age-crime curve 144

anger: victim experience of 16-17, 227; victim

expressions of 5, 23-24, 213-14 see also emotion, blame

apology 230, 232-34, 265

autonomy ideal 33-35

Baldwin, James 274, 296

Batson v. Kentucky 85

belonging: incarceration and 102-03; need for 31-32; race and 291-97; relational justice and 2, 223, 264, 267, 308, 311-13; violence as harm to 21, 72, 213

Bicknell, Janet 252

blame: character blame, 55-57; for child sexual abuse, 54-55; for lying 44-46; in popular culture, 46-47 Bosch, Stan 306

Bracamontes, Christian 150-51

Brown, Michael 278

Buck v. Davis 85

Byrne Jr., William Matthew 237

California: Department of Corrections and Rehabilitation, 159, 187 n.20; mandatory life sentences 129-55; propositions, 133-37; rates of crime and incarceration 134, 138-39; sentencing reforms 148

Cameron, Gail 228, 230

capital punishment see death penalty care for the hurt see relational justice, traits for CeaseFire 264-66
Chairez, Rita 225, 239

change for offenders see redemption, reformation child sexual abuse: legal liability 50-53; moral disregard 54-55; perpetrator's perspective on 53-54; soul harm of 50-51

Clinical Pastoral Education (CPE) 224-25

closure 237-38

Columbine High School shooting 59-60

confidence see sentencing, traits for sentencers conditions of incarceration see inmates, prisons conviction: distinguished from punishment decisions 106-07

correctional officers 159, 167-69,

182,260

courage see relational justice, traits for

criminal intent see mens rea

Culvey, Adam see Cameron, Gail

Daily, Thomas V. 80-81

Davis, Richard Allen see Polly Klaas

Death penalty: in California 135-37; individualized sentencing and 122-23; race and 84-86 see also Payne v. Tennessee

deterrence: defined 108-09; Eighth Amendment and 122; in sentencing decisions 117-18; Three Strikes and 143

Deukmejian, George 136

Dickens, Charles 171-72

Dirty Harry 132-33

Douglass, Frederick 292-93

Du, Soon Ja see Harlins, Latasha

due process $67,110-12,115$

Duncan v. Louisiana 84 
Eastwood, Clint 34, 132-33

Egan, Edward M. 78

Eighth Amendment 100, 121-24, 208-09

emotion: blame $64,82-83,87,152-53$; connections to others 33-37; effects of violence $21-25$; listening to victims and $4-5$; and needs of community versus victims 290-91; perpetrator culpability and $47-50$; prosecutors and 235-36; self-awareness, need for 308-309; sentencing and 109-10, 117-18, 203-17; suppression of 246-49; victim-offender relations 227-31; see also sentencing, moral capacity

Equal Justice Initiative 285

Eulian, Ian see Stafford, Rebecca

faith: in justice 305-06

fear: of crime generally 4; of not belonging 76-77, 248; of police 278; race related 4, 88-90, 278-79, 294-95; of sexual violence in prison 178-83, 204; of victim emotions 227; victim experience of 22-23, 29,129-31, 233, 252

Fitzgerald, Gerald 74

forgiveness: of abusive priests, 78-79, 82, 100; relation to justice, $230-32$

Furman v. Georgia see death penalty

Gallant, Mary 79-80

Gang Violence and Juvenile Crime Prevention Act of 1998141

Garner, Edward see Tennessee v. Garner

generative activities 263

Geoghan, John J. 78-81

Giuliani, Rudy 286-87

Goetz, Bernhard 88-89

Golden State Killer 238

Gonzalez, Edel 252-53

good guys $\mathrm{v}$. bad guys thinking see personalized morality

Graham v. Florida 124

Greene Correctional Facility 296

Grossman, David 230

guilty plea: due process 111-12; relational justice 236-37

Haney, Craig 174

Harlins, Latasha 275-76

Harris, Eric see Columbine High School

Healing Dialogue and Action (HDA) 266

Human Rights Watch 146

humility see relational justice, traits for; sentencing, traits for sentencers

hypermasculinity see power masculinity

incapacitation $143-45$

incarceration: rate in US 119, rate in California 134; see mass incarceration inmates: families of $6-7,102-03$, profile of prison inmates 162-64; security for 167-68 see also sexual violence, solitary confinement, reformation InsideOut 275-76

justice see legal justice, relational justice.

judicial temperament 118-19, 210

Karlin, Joyce see Harlins, Latasha

King, Rodney 130, 138, 274, 276-77

Klaas, Polly 139-40

Law, Bernard 80-81

law enforcement: clearance rates 199; rape investigations $200-01$

legal justice 197-211; 216-17, 238

legislative sentencing, $149-50$

Leovy, Jill 290

listening see relational justice

Loera, Omar see Cameron, Gail

Los Angeles Police Department (LAPD) 138, 228, 233, 275

mandatory life sentences see California

Marlantes, Karl 253

Marsy's Law 203

Martinson, Robert 169

mass incarceration 3-4, 104, 120-21, 166, 244

Medeiros, Humberto 79-80

Memphis police department see Tennessee v. Garner mens rea 51, 56-57

mental illness: childhood trauma and 51; inmates and $146,163,174-77,185-86$

mercy discrimination 276, 280-84

Miller v. Alabama 124

moral capacity 57-60 see also responsibility

moral disregard: armed robbery 104-06; child sexual abuse 54-55; objections to blame for 55-63; in punishment 147-50; violent crime as 170,213 , 217 see also sexual violence, solitary confinement moral regard: blame and 64, 89-90, 205; empathy and 58-60; incarceration and 161-62, 186; individual freedom and 62-63; offender-victim relations 234; punishing with 101, 116-24; race and 273, 283; reformation and 251, 255; victim impact statements and $214-15$ see moral disregard

Mothers Against Drunk Driving 103-04

mourning see relational justice

Murphy, Jeffrie 100, 231

Narcotics Anonymous see redemption

Nassar, Larry 213-14

Neidorf, Barry J. detention hall 154

no frills movement, 166 
nonrecognition of wrongs: child sex abuse 69-77; race bias, $82-88$

numbness from violence see trauma

O'Callaghan, Mary 233-34

Osmanhodzic, Cheree see Cameron, Gail

pain: courage to engage others' pain 304; offender reformation and 247-68; punishment and 101-07, 125; of victims of violence, 20-22, 24, 27, 33, 50, $153,211,223,228,236,245-47$

Payne v. Tennessee 208-09

parole: decisions $247,252-53,261-62$; history of 155-69, 173; victims rights and 202-03, $247,252-53$

penal harm movement see no frills movement

personalized morality: generally $68-69,91,131,318$; for Catholic priests, 75-76; race bias and 86-88

Peterson, Scott 23-24

power masculinity $182-83$

prison: history of $165-67,171-74$; public responsibility for 161-62; racial segregation in 85 ; security of 160, 167-69 see inmates, mass incarceration

prison gangs $125,173-74$

prison guards see correctional officers

Prison of Peace 258

Prison Rape Elimination Act of 2003 (PREA) 184

prisoners see inmates

probation 165 see also reformation

prosecutors: relational justice and, 235-36; victims and legal justice, 207, 215-17

propositions see California

Pryor, Douglas W. 53

psychopathy see moral capacity

punishment: failure to punish wrongdoers $77-78$; incarceration as 102-03; justification for 103-110; principles of, 108-09; social injustice and 110-116 see also inmates, moral regard, mass incarceration

race: discrimination in criminal justice 113,120 ; personal identity and 36; fear and 4, 88-90; history of discrimination 61-63; history of racial violence 285-86; incarceration rates and 120,163; homicide and 286-91; police use of force and 274-85; unconscious bias 82-90; victims rights movement and 204-05; white perspectives on 272-74, 292-97

Raisman, Aly see Nassar, Larry

rape kits 201

redemption: defined 243-45; dialogues and 264-67; past pain and 249-53; education and training, 258-59; religious conversion 255-57; responsibility for past wrongs $252-55$; story telling and $255-58$ see also reentry, parole

reentry $262-63$ reformation 169-172, 179, 244-45 see also redemption

rehabilitation see also reformation, redemption relational identity 35-38

relational justice: generally 7-8, 195-96, 230-34, 302-09; accompaniment, 224-26; changing victim-offender relations 227-34; listening to victims $4-5$, 223-24;

mourning 226-27

responsibility: generally $42-43$; moral responsibility, 44-46; personal responsibility for past actions 255-55; social expectations and 60-61 see also moral disregard, moral regard, punishment restorative justice 8,258

retribution $108-09$

Reynolds, Mike 129, 139-41

Roman Catholic Church see nonrecognition of wrongs: child sexual abuse

Sandy Hook see accompaniment

Sebold, Alice 23

security: institutional 168; prison, 166-69, 172-73, 176, 179; for victims 198-202

Security Threat Group see prison gangs

sentencing: allocution 112-13; basic considerations 107-09; character traits for sentencers 118-19; emotion and 109-10; determinate 166-69; indeterminate, 165-66; individualized, right to $123-24$

sexual violence $2-3,69-70$; child sexual abuse $50-55$, $70-82$; in prison 178-84; investigation of rape 200-02; perpetrator perspective 48-49; victim experience of 28-31; see also nonrecognition, victim impact statements

shame: acceptance of past wrongdoing and 251-55; institutional 85; racial history $273-74,286$; victim experience of 6-7, 72, 179, 181, 183, 302 social-moral education 73

solitary confinement $166,171-77,185-86$

soul: challenges of modern life and 185-86; violence and damage to $27-32,179,212,234,237$; solitary confinement 176-77 see also sexual violence

Southland 68,82

spirit harms see soul

Stafford, Rebecca 8-13

Stauring, Javier 177

Stevenson, Bryan 285, 304; see also Equal Justice Initiative

Strong and Free Inside 154

supermax 172-74, 177

survivors see victims

Tennessee v. Garner 281-83

Tests of Adult Education (TABE) 163 
Three Strikes law (California): background to 132-39; effect of 145-46; justice of 145-46, 148-53; reform of 148

trauma: childhood experience of 22, 51, 58, 114, 147, 246-47, 249-51; healing from 250, 29-231; punishment and 115-16; rape victims and police 200; victims of violence generally 19, 22, 74, 114, 206, 304

Twin Towers Correctional Facility 185, 311-15

Vayan, Eddy 225-26

victims: 16-39, 197-240; see also emotion, relational justice, sexual violence, trauma victims rights movement 202-11

Victims Bill of Rights 136

victim impact statements 207-15

Victim Offender Education Group (VOEG) 257

violence: criminal violence defined 19; rate in California 134, in US 18; minority on minority homicide 286-91 see also sexual violence, soul, trauma

Webster, Vance 147

Wilson, Darren 279

Yom HaShoah 285 